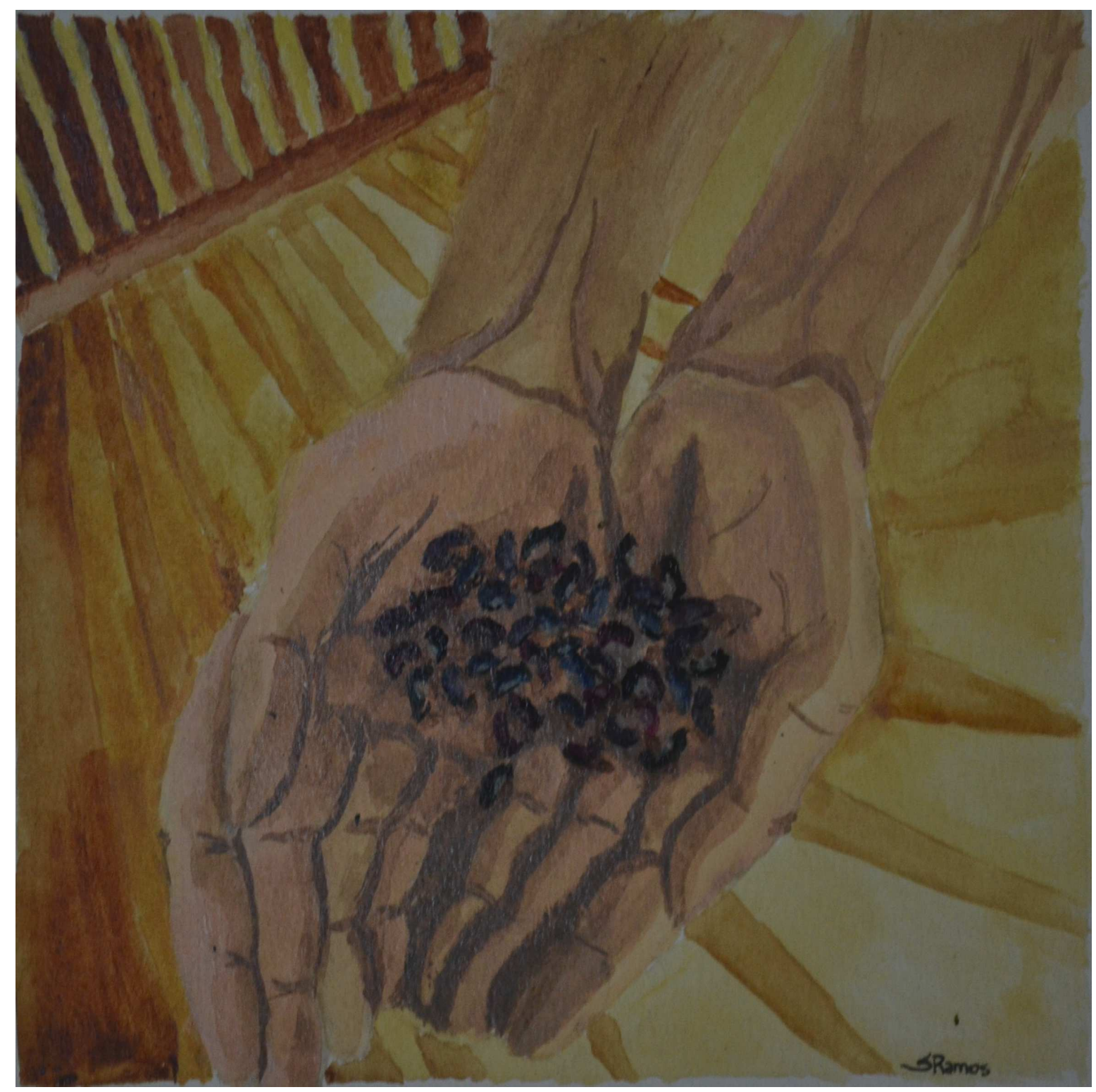

ESTRATÉGIAS SOCIOAMBIENTAIS DA SOBERANIA ALIMENTAR 


\begin{abstract}
UNIVERSIDADE DE SÃO PAULO
INSTITUTO DE ENERGIA E AMBIENTE

PROGRAMA DE PÓS-GRADUAÇÃO EM CIÊNCIA AMBIENTAL

PROCAM
\end{abstract}

SUÊNIA CIBELI RAMOS DE ALMEIDA

ESTRATÉGIAS SOCIOAMBIENTAIS DA SOBERANIA

ALIMENTAR

SÃo PAULO

2018 
SUENIA CIBELI RAMOS DE ALMEIDA

\section{ESTRATÉGIAS SOCIOAMBIENTAIS DA SOBERANIA ALIMENTAR}

Tese apresentada ao Programa de PósGraduação em Ciência Ambiental/PROCAM do Instituto de Energia e Ambiente da Universidade de São Paulo para obtenção do título de doutora em Ciência Ambiental.

Orientação: Prof. Dr. Wagner Costa Ribeiro (PROCAM/IEE/USP e Departamento de Geografia da FFLCH/USP)

Versão Corrigida

(versão original disponível na Biblioteca do Instituto de Energia e Ambiente e na Biblioteca Digital de Teses e Dissertações da USP)

São Paulo-SP

2018 
AUTORIZO A REPRODUÇÃO E DIVULGAÇÃO TOTAL OU PARCIAL DESTE TRABALHO, POR QUALQUER MEIO CONVENCIONAL OU ELETRÔNICO, PARA FINS DE ESTUDO E PESQUISA, DESDE QUE CITADA A FONTE.

FICHA CATALOGRÁFICA

Almeida, Suenia Cibeli Ramos de.

Estratégias socioambientais da soberania alimentar./Suenia Cibeli

Ramos de Almeida; orientador: Wagner Costa Ribeiro. - São Paulo, 2018. 197f.: il; $30 \mathrm{~cm}$.

Tese (Doutorado em Ciência Ambiental) - Programa de PósGraduação em Ciência Ambiental - Instituto de Energia e Ambiente da Universidade de São Paulo.

1. Ecologia agrícola - aspectos políticos - socioeconômicos. 2.

Política ambiental. 3. Políticas públicas. I. Título. 


\section{FOLHA DE APROVAÇÃO}

Nome: ALMEIDA, Suênia Cibeli Ramos de

Título: Estratégias socioambientais da soberania alimentar.

Tese apresentada ao Programa de PósGraduação em Ciência Ambiental/PROCAM do Instituto de Energia e Ambiente da Universidade de São Paulo para obtenção do título de doutora em Ciência Ambiental.

Aprovado em:

Banca Examinadora

Prof. Dr.

Instituição:

Julgamento:

Assinatura:

Prof. Dr.

Instituição:

Julgamento:

Assinatura:

Prof. Dr.

Instituição:

Julgamento:

Assinatura:

Prof. Dr.

Instituição:

Julgamento:

Assinatura:

Prof. Dr.

Instituição:

Julgamento:

Assinatura:

Prof. Dr.

Instituição:

Julgamento:

Assinatura: 
AOS CAMPONESES DO BRASIL DEDICO 


\section{AGRADECIMENTOS}

Os ciclos humanos guardam similitudes com os naturais, são processos e como tais trazem essa capacidade do recomeço, num movimento circular entre começo, meio e fim. Assim, são para mim os ciclos de aprendizagens formais que estão sempre embrenhados de informalidades. Chegada o momento do fechamento desse ciclo formativo, reconheço que partirei com muitos aprendizados, algumas lacunas e vários questionamentos. O mais importante é reconhecer e agradecer os diversos e múltiplos encontros no caminhar desse doutoramento. Se a memória não me falhar, listarei, em primeiro lugar as instituições, devido ao importante papel que desemprenharam para tornar esse momento possível e no formato que ele aconteceu, foram elas: a Empresa Brasileira de Pesquisa Agropecuária - EMBRAPA minha Casa de trabalho, local onde vivo há 23 anos. Morada de muitos amigos e vários projetos para apoiar a agricultura camponesa. A realização deste curso foi possível pela existência do programa de pós-graduação strictu senso da empresa que já formou vários pesquisadores nesse país. Meu muito obrigada e que este programa tenha vida tão longa quanto a Embrapa. Aos conselheiros acadêmicos, Otávio Valentim Balsadi, numa primeira fase, e Patrícia Bustamante pela presteza e amizade em todos os momentos desse processo.

A Universidade de São Paulo por meio do Instituto de Energia e Ambiente e do Programa de Pós-Graduação em Ciência Ambiental/PROCAM que forneceram às condições estruturais e educacionais para a realização do curso.

Ao professor Wagner Costa Ribeiro que me acolheu para orientação, o que possibilitou a desconstrução do projeto original e a possibilidade de trabalhar numa abordagem coerente com a minha trajetória de vida, muita gratidão. Ao Grupo de Pesquisa de Geografia Política e Meio Ambiente, coordenado pelo professor Wagner, interdisciplinar e intergeracional pelos debates calorosos sobre os processos que envolvem a política, a ciência e as questões socioambientais. 
Ao Movimento dos Pequenos Agricultores - MPA/Brasil e aos camponeses que acolheram o projeto de doutoramento, abriram as portas de sua organização, suas moradas, suas vidas e suas histórias. Sem esse acolhimento, nada seria possível. Eternamente grata!

A Universidade do Arizona, a professora Dra. Tracey Osborne e ao grupo de pesquisa em Ecologia Política-PPEL por me receberem para o estágio sanduíche, na Escola de Geografia e Desenvolvimento, na cidade de Tucson/Arizona, no período de junho de 2017 a abril de 2018.

Viver na cidade de São Paulo é uma experiência única e de alma e origem nordestina não poderia deixar de constituir laços afetivos com a cultura da cidade. Portanto, sou ternamente grata ao grupo cultural Ilu Oba De Min - Educação, Cultura e Arte Negra - que me acolheu nas tardes de sábado, no Vale do Anhagabaú e aos domingos, na Praça do Patriarca, para o toque dos tambores, numa roda que reunia aproximadamente 300 mulheres. É uma energia vibrante. Meu muito obrigada a mestre Mazé Cintra e as amigas de alfaia, Mônica e Maria Alice.

Aos muitos amigos, os de ontem, os de hoje e os que torceram desde sempre por mim e que mesmo distantes, estão sempre conectados comigo. Sintam-se parte do que hoje entrego: Gratidão. Lúzia, France, Selma, Marcelo, Zé Humberto, Waldyr, Fernando(s), Kilvia, Zenaida, Lívia, Ana (s), Giovanna, Karinho....

A quem me fez parte do que sou, minha imensa e calorosa família paraibana que esteve todos os dias comigo, muito obrigada! Meu pai Francisco Eugênio e minha mãe Maria das Neves e minha coleção de irmãos: Regina, Silvania, Simone, João Batista e Francisdo das Chagas. Minhas sobrinhas: Fernanda, Fabianne, Vitória, Letícia, Loise, João Pedro, Maria Eduarda e Ademir.

Obrigada ao Martinho, Agatha e Dani que acolheram a minha maior sabedoria, Sofia Ramos de Almeida Andrade - minha filha - que durante os dois anos que estive entre São Paulo e Tucson, esteve estudando. Grata filha pela longa espera, pelos apoios, pelas idas e vindas e pela pessoa linda que a vida tem lhe transformado! Estou voltando. Obrigada! 


\section{RESUMO}

ALMEIDA, S. C. R. Estratégias socioambientais da soberania alimentar. 2018. 197fls. Tese (doutorado em Ciência Ambiental). Programa de Pós-Graduação em Ciência Ambiental, Instituto de Energia e Ambiente, Universidade de São Paulo, São Paulo, 2018.

Este trabalho trata da narrativa de resistência que o Movimento de Pequenos AgricultoresMPA constituiu para resistir aos processos de expropriação das sementes dos camponeses, no estado de Santa Catarina, Brasil. O objetivo é analisar como o projeto de sementes do movimento influenciou a construção da soberania alimentar por meio de suas ações junto às instituições. Como instrumentos metodológicos fontes primárias e secundárias foram utilizadas, levando em consideração o referencial teórico da ecologia política, focado em conceitos de conflitos socioambientais, justiça ambiental e soberania alimentar. Assim, foi realizada pesquisa de campo, nos anos de 2015 e 2016, nos estados do Distrito Federal, Santa Catarina e Rio Grande do Sul, com diferentes atores que participaram do processo. Da análise constata-se que o movimento por meio da cooperativa Oestebio, desenvolveu a experiência de massificação de sementes crioulas e varietais a partir de uma ampla articulação de ações, alianças com instituições e outros movimentos, influenciando e sendo influenciado por políticas públicas e ações do Estado para constituir a soberania genética com base no projeto de soberania alimentar. Ao teceram uma longa teia de relações, articulando os campos político, econômico, científico e socioambiental, ancorado no diálogo constante nos diferentes níveis - local, regional, nacional e internacional - constituíram uma experiência portadora da soberania alimentar dentro dos limites atuais da economia política contemporânea, expropriadora de recursos e geradora de conflitos e injustiças socioambientais.

Palavras-chave: Movimento de Pequenos Agricultores. MPA/BRASIL. Soberania alimentar. Justiça Ambiental. Conflitos Socioambientais. Soberania Genética. 


\begin{abstract}
ALMEIDA, S. C. R. Socio-Environmental strategies of food sovereignty. 2018. 197fls. $\mathrm{PhD}$ thesis (Environmental Science $\mathrm{PhD}$ ). Graduate Program in Environmental Science, Environment and Energy Institute, University of Sao Paulo, Sao Paulo, 2018.

This thesis is about the resistance narrative of Small Farmers Movement has established to resist to expropriation of peasants' seeds, in the Santa Catarina state, Brazil. The goal is to analyze how the project of seed of the movement has impacted the food sovereignty throughout its actions with institutions. Primary and secondary sources were used as methodological tools taking account the political ecology approach, focusing on concepts such as socio-environmental conflicts, environmental justice and food sovereignty. A field work was conducted, in 2015 and 2016, in Distrito Federal, Santa Catarina and Rio Grande do Sul states, interviewing several actors who took part of this process. It was verified that the movement by means of Oestebio cooperative developed the experience of multliplication of native and varietals seeds throughout a broad articulation of actions, alliances with institutions and others social movements. It has influenced and has received influence of public policies and State actions to constitute genetic sovereignty based on its food sovereignty project. By weaving a long web of relations, connecting the political, economical, scientific and socioenvironmental fields, based on a frequent dialogue in different levels - local, regional, national and international - they built an experience of food sovereignty inside current limits of the political economy, expropriator of resources and producer of socio-environmental conflicts and injustices.
\end{abstract}

Keywords: Small Farmers Movement. MPA/BRASIL. Food Sovereignty. Environmental Justice. Socio-Environmental Conflicts. Genetic Sovereignty. 


\section{SIGLAS E ABREVIATURAS}

Abrasem - Associação Brasileira de Sementes e Mudas

BAG - Banco Ativo de Germoplasma

CDB - Convenção da Diversidade Biológica/1992

CAPES - Coordenação de Aperfeiçoamento de Pessoal de Nível Superior

CENARGEN - Centro Nacional de Pesquisa de Recursos Genéticos e Biotecnologia (Embrapa Recursos Genéticos e Biotecnologia)

CGEN - Conselho de Gestão do Patrimônio Genético (MMA/Brasil)

CGIAR - Grupo Consultivo em Pesquisa Agrícola Internacional

Conab - Companhia Nacional de Abastecimento

CONAQ - Coordenação Nacional das Comunidades Quilombolas

CNPq - Conselho Nacional de Desenvolvimento Científico e Tecnológico

CONSEA - Conselho Nacional de Segurança Alimentar e Nutricional

CONTAG - Confederação Nacional dos Trabalhadores na Agricultura

GRAIN - Genetic Resources Action International

CTNBio - Comissão Técnica Nacional de Biotecnologia

CUT - Central Única dos Trabalhadores

EMBRAPA - Empresa Brasileira de Pesquisa Agropecuária

EPAGRI - Empresa de Pesquisa Agropecuária e Extensão Rural de Santa Catarina

FASE - Federação de Órgãos para Assistência Social e Educacional

FAO - Food and Agriculture Organization of the United Nations

FETAESC - Federação dos Trabalhadores e Trabalhadoras Rurais do Estado de Santa Catarina

FETRAF/Brasil - Federação Nacional dos Trabalhadores e Trabalhadoras na Agricultura Familiar no Brasil

FIOCRUZ - Fundação Oswaldo Cruz

IAC - Instituto Agronômico de Campinas

IAPAR - Instituto Agronômico do Paraná

IBAMA - Instituto Brasileiro do Meio Ambiente e dos Recursos Naturais Renováveis

IBGE - Instituto Brasileiro de Geografia e Estatística

IBPGR - Conselho Internacional para os Recursos Genéticos Vegetais

IPGRI - International Plant Genetic Resources Institute (atualmente Bioversity International)

IUCN - The World Conservation Union (UICN em português)

LABEX - Laboratório Virtual da Embrapa no Exterior

MAPA - Ministério da Agricultura, Pecuária e Abastecimento/Brasil

MCTI - Ministério da Ciência, Tecnologia e Inovação/Brasil

MAB - Movimento dos Atingidos por Barragens

MDA - Ministério do Desenvolvimento Agrário/Brasil

MDS - Ministério do Desenvolvimento Social e Combate a Fome

MMA - Ministério do Meio Ambiente/Brasil

MMC - Movimento de Mulheres Camponesas

MPA - Movimento de Pequenos Agricultores

MPP - Movimento de Pescadores e Pescadoras Artesanais

MST - Movimento dos Trabalhadores Rurais Sem Terra

OGM - Organismo Geneticamente Modificado

OMC - Organização Mundial do Comércio

OMPI - Organização Mundial para Proteção Intelectual

ONU - Organização das Nações Unidas

PAA - Programa de Aquisição de Alimentos 
PJR - Pastoral da Juventude Rural

PLANAPO - Política Nacional de Agroecologia e Produção Orgânica

PNATER - Política Nacional de Assistência Técnica e Extensão Rural

PROAGRO - Programa de Garantia da Atividade Agropecuária

PRONAF - Programa Nacional de Fortalecimento da Agricultura Familiar

RNC - Registro Nacional de Cultivares

RENARGEN - Rede Nacional de Recursos Genéticos

RGV - Recursos Genéticos Vegetais

SEAF - Seguro da Agricultura Familiar

SNSM - Sistema Nacional de Sementes e Mudas

SNPA - Sistema Nacional de Pesquisa Agropecuária

TIRFFA - Tratado Internacional sobre Recursos Fitogenéticos para a Alimentação e a Agricultura

TRIPS - Trade-Related Aspects of Intellectual Property Rights Agreement

UFSC - Universidade Federal de Santa Catarina

UNAIC - União das Associações Comunitárias do Interior do Canguçu

WWF - World Wildlife Foundation

Wipo - World Intellectual Property Organization (Ompi em português)

WTO - World Trade Organization 


\section{SUMÁRIO}

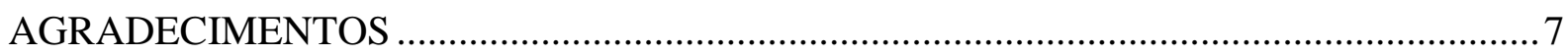

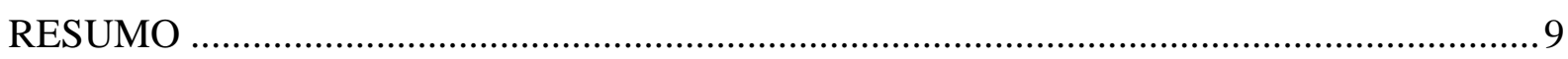

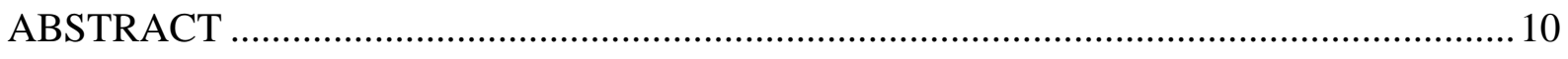

INTRODUÇÃ

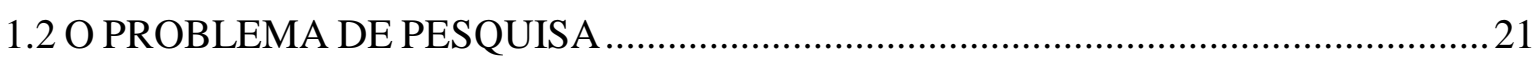

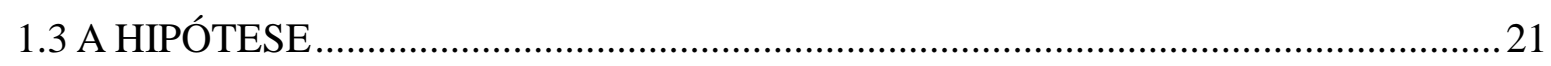

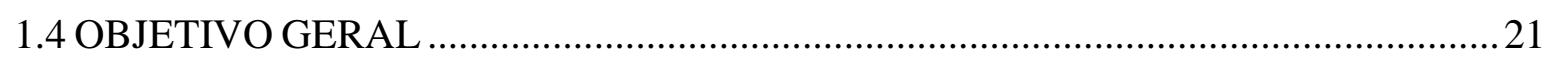

2. MÉTODO, METODOLOGIA E INSTRUMENTOS DE PESQUISA ............................22

CAPÍTULO I - SOBERANIA ALIMENTAR, ECOLOGISMO DOS POBRES E

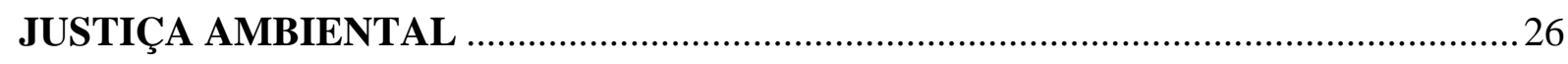

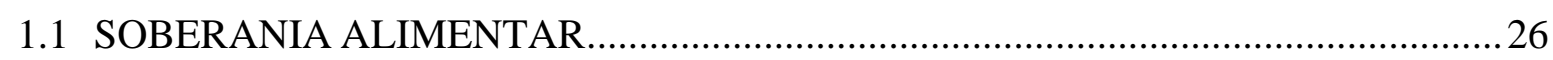

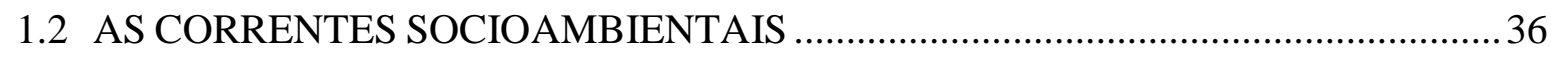

1.3 O ECOLOGISMO DOS POBRES ................................................................... 41

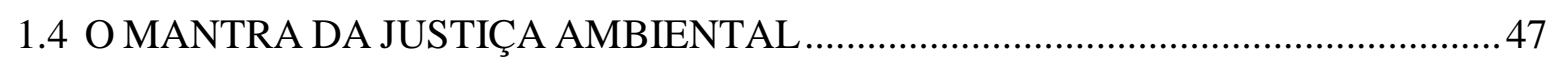

CAPÍTULO II - INJUSTIÇA SOCIOAMBIENTAL: CONCENTRAÇÃO DA TERRA

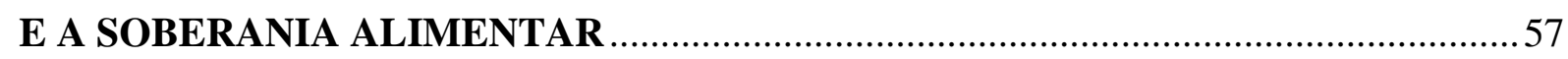

2.1 INJUSTIÇA SOCIOAMBIENTAL - A CONCENTRAÇÃO DA TERRA .57

2.2 RECONCENTRAÇÃO DA TERRA OU INTENSIFICAÇÃO DA PRESENÇA DO CAPITAL?

CAPÍTULO III - CONSTRUINDO A SOBERANIA ALIMENTAR E A SOBERANIA GENÉTICA: O PROJETO DE SEMENTES DO MOVIMENTO DOS PEQUENOS AGRICULTORES - MPA/BRASIL .82 
3.1 O MOVIMENTO DOS PEQUENOS AGRICULTORES - MPA E A CONSTRUÇÃO DA SOBERANIA ALIMENTAR. 82

3.2 O TERRITÓRIO - PAISAGEM CAMPONESA NO OESTE DE SANTA CATARINA

3.3 A EXPERIÊNCIA DO MPA NO SUL DO PAÍS - SANTA CATARINA 95

3.4 CONTEXTO INSTITUCIONAL, NORMATIVO E POLÍTICO 105

CAPÍTULO IV - A CONSTRUÇÃO DA RESISTÊNCIA 113

4.1 A EXPERIÊNCIA DE MASSIFICAÇÃO - O DESAFIO DE SANTA

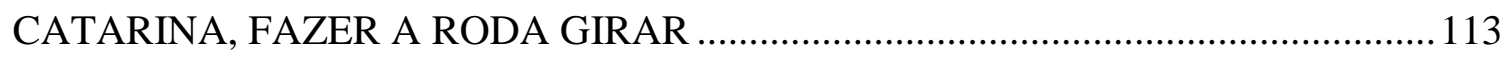

4.2 OS PROCESSOS DE RECONHECIMENTO .................................................... 136

4.3 APRENDIZAGENS DA CONSTRUÇÃO DA SOBERANIA ................................ 166

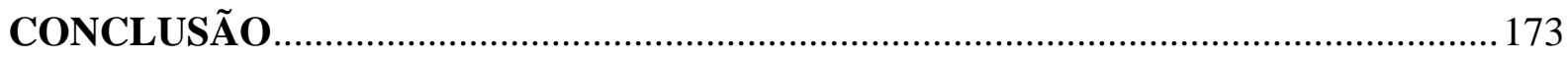

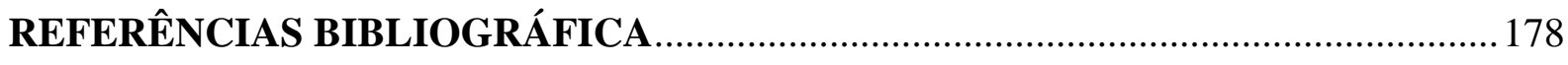

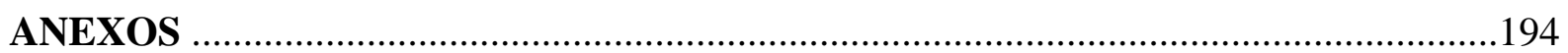




\title{
INTRODUÇÃO
}

\begin{abstract}
"Minha questão diz respeito, antes, a que, coletivamente, se não como indivíduos, esses homens e mulheres são os principais atores da história. O que realizam e pensam faz a diferença. Pode mudar, e mudou, a cultura e o perfil da história, e mais do que nunca no século XX. Essa é a razão por que dei o título a um livro sobre essas pessoas, tradicionalmente conhecidas como "pessoas comuns', de Pessoas extraordinárias” (HOBSBAWM'1 2016, pg. 8).
\end{abstract}

Abro este trabalho fazendo referência a frase de Hobsbawm (2016) na abertura do seu livro que trata sobre os processos de resistência, rebelião e jazz que as pessoas consideradas comuns produziram na história da humanidade e que mostram como são importantes os processos de contramovimento (POLANYI, 2012), que de tempos em tempos, as pessoas extraordinárias colocam em marcha. O presente trabalho é uma narrativa sobre o processo de resistência que um movimento camponês, chamado Movimento de Pequenos Agricultores, conhecido por MPA, se propôs a construir para resistir aos processos de expropriação das sementes dos camponeses, a partir do estado de Santa Catarina, no sul do Brasil.

O processo de expropriação das sementes dos camponeses já vem de longa data, 1890, como descrito por Kloppenburg (2004) e que se traduz primariamente pela captura das sementes pela ciência do melhoramento de plantas através do que ficou conhecido como sementes híbridas. Esse processo possibilitou a apropriação e transformação das sementes dos camponeses em mercadoria por meio de uma engenharia tanto no campo do melhoramento de plantas vegetais quanto no campo do direito de propriedade que possibilitou o empacotamento da semente e sua ampla comercialização por meio do projeto da revolução verde.

Para Kloppenburg (2004) a pesquisa científica, aí incluídas a ciência básica e a tecnológica, vem desempenhando um importante papel para a entrada do capitalismo na agricultura, desconstituindo barreiras naturais, anteriormente intransponíveis, para possibilitar formas de transformação da natureza em mercadoria que possam ser apropriadas pelo capital. O caso do melhoramento de plantas e, na sequência, a engenharia genética e as biotecnologias estão entre os principais fatores responsáveis pela transformação das sementes em mercadoria em um mercado altamente lucrativo.

Esse processo se amplia com o desenvolvimento da engenharia genética e o desenvolvimento dos transgênicos. Essa aliança entre a ciência e a indústria foi a porta de entrada para o avanço das multinacionais no setor de sementes que hoje se expressa nas

\footnotetext{
${ }^{1}$ HOBSBAWN, Eric. Pessoas extraordinárias: resistências, rebelião e jazz. 4 ${ }^{a}$. Edição. São Paulo: Paz e Terra, 2016.
} 
relações sociais, econômicas e políticas no país por meio da concentração de terra, renda, poder e mando e, na mesma medida expropriando riquezas e produzindo um rastro de pobreza, conflitos, degradações e injustiças socioambientais.

No campo dos processos legais, as grandes do setor vêm progressivamente capturando o direito de guardar e replantar as sementes, uma prática secular dos camponeses; o direito de compartilhar, receber e trocar sementes de outros camponeses que fundamenta a própria possibilidade de aumentar a diversidade genética e o direito de usar as sementes e gerar novas variedades. Foi esse processo que garantiu a constituição de uma hegemonia e expropriação do território. Vale salientar, não sem resistência, é claro.

Para ilustrar a grandeza em termos de números, no ano de 2016, o Brasil ocupou o $2^{\circ}$ lugar no ranking mundial de área plantada com sementes transgênicas no mundo com 49.1 milhões de hectares, alcançando $27 \%$ da área plantada globalmente, ficando atrás apenas dos Estados Unidos da América do Norte com 72.9 milhões de hectares, equivalendo 39\% da área global. Essa área corresponde aos cultivos de soja, milho e algodão. Estima-se que a área plantada com essas culturas no país, naquele ano, tenha sido de 52.6 milhões de hectares, isso corresponde ao percentual de 93,4\% de área plantada com sementes transgênicas. Esse relatório ainda traz a informação que este mercado mobilizou sozinho, no território brasileiro, no período de 10 anos - 2003 a 2015 - valores de recursos da ordem de US\$ 16.4 bilhões e, apenas no ano de 2015, o montante de US\$2.5 bilhões (ISAAA, 2016).

De acordo com OXFAM INTERNATIONAL (2018), aproximadamente 60\% do mercado de insumos agrícolas (sementes, agrotóxicos, fertilizantes) está concentrado em apenas três grandes empresas multinacionais - Bayer/Monsanto ${ }^{2}$, DuPoint/Dow e ChemChina/Syngenta ${ }^{3}$ - e representa uma grande ameaça aos modos de vida tradicionais dos camponeses, povos indígenas, comunidades tradicionais e agricultores familiares, na medida em que há uma enorme concentração de poder político e de mercado centralizado nessas grandes empresas. Isso significa a fragilização da soberania alimentar e territorial dos camponeses.

Esse cenário explica o fato da criação de mecanismos de apropriação de recursos anteriormente públicos e de livre acesso por meio de regulamentações proibitivas e privatistas e, sobretudo, a caracterização das práticas camponesas como ilegais. É importante ressaltar os

\footnotetext{
${ }^{2}$ A Bayer - multinacional alemã do setor farmacêutico e agricultura - comprou as operações da Monsanto, envolvendo as atividades de sementes e agricultura de precisão, pelo valor de US\$ 63 bilhões, em junho de 2018 (https://economia.uol.com.br/noticias/afp/2018/06/04/bayer-anuncia-o-fim-da-marca-monsanto.htm). Última consulta: 02.07.2018.

3 A empresa chinesa ChemChina - China National Chemical Corporation - comprou a empresa suíça Syngenta, no ano de 2017, no contexto das fusões desse tipo de operações que vem ocorrendo no mundo.
} 
diversos impactos e efeitos negativos que têm sido registrados tanto no setor de pesquisa quanto no da erosão genética para os camponeses que vivem da agricultura.

A observação, seleção, coleta e armazenamento de sementes foi por muitos séculos uma prática de agricultores e camponeses que cultivam a terra e vivem da relação com o manejo da natureza (ou dos recursos que a natureza oferece), da atividade que se convencionou chamar agricultura. Essa atividade que compõe o repertório dos sistemas de manejo, produção e reprodução de alimentos realizada pelos agricultores e camponeses vem sendo, nas últimas décadas, com o avanço do capital no campo, questionada por empresas transnacionais detentoras de sementes 'melhoradas', envelopadas/empacotadas no conjunto do pacote tecnológico desenvolvido desde a década dos 1950, por meio da Revolução Verde.

Esse processo de disputa de legitimidade, tanto dos formatos de coleta como do armazenamento e conservação, envolveu, nos últimos anos, uma diversidade de atores estatais, organizações não governamentais, instituições internacionais, instituições científicas, sociedade civil e movimentos sociais produzindo um legado de práticas seja do ponto de vista do arcabouço jurídico; da articulação em rede e novas organizações do movimento camponês em nível internacional, bem como experimentações e inovações sociais e locais produzidas pelos camponeses e coordenadas por diferentes atores sociais para fazer frente a esse avanço.

Partindo de um problema socioambiental concreto, a saber, a perda da agrobiodiversidade e da autonomia camponesa, busquei examinar por meio da abordagem da ecologia política os principais fatores do problema e compreender como o Movimento de Pequenos Agricultores constituiu sua resistência por meio do projeto político da soberania alimentar e da soberania genética. Compreendo que a questão socioambiental não está dissociada da dinâmica da economia política. Nessa medida, a abordagem da ecologia política torna-se uma abordagem teórica apropriada porque produz uma leitura que resgata tanto os movimentos da economia política, da sociedade e seus conflitos e de como esses interagem na produção de impactos, efeitos e consequências sobre esses problemas, desafios e possibilidades socioambientais na contemporaneidade.

Nesse contexto, o debate sobre a justiça ambiental e a soberania alimentar envolve a disputa pelo poder político e econômico entre os camponeses e as grandes corporações e estados nacionais com diversos impactos sobre as formas de acesso e distribuição dos recursos socioambientais, como também a participação nos processos definidores de políticas nos âmbitos comercial, das leis de patentes, do uso de solos, da água, da regulação de agrotóxicos, dos subsídios, de leis trabalhistas e das regras que regulam esses mercados. Esse 
debate é importante porque envolve uma parcela considerável de pessoas, não apenas no país, mas sobretudo, nos países em desenvolvimento.

Lowder et al. (2016), analisando informações do censo agropecuário de $167^{4}$ países, estimam que existem no mundo mais de 570 milhões de propriedades agrícolas. Dessas $4 \%$ estão localizadas em países de rendas altas; $13 \%$ nos países de rendas baixas; $47 \%$ em países de rendas médias altas e 36\% nos países de rendas médias baixas. Dentre essas, mais de 475 milhões estão representadas por explorações com menos que 2 ha, representando $84 \%$, e ocupando uma área de menos de $12 \%$ do total das terras agrícolas. A maioria dessas propriedades agrícolas encontra-se em países com rendas de baixas a médias. Dessa magnitude os autores concluem que provavelmente os agricultores familiares e camponeses são os principais responsáveis pela produção de alimentos no mundo.

O Brasil está entre os países com a maior parte das terras agrícolas do mundo, estando em ordem de grandeza na seguinte escala: 11\% na China; 9\% na Austrália; 8\% nos Estados Unidos da América; 5\% no Brasil e 4\% na Federação Russa. Com um padrão de concentração de terra semelhante ao que ocorre na maior parte da América Latina e Caribe, onde predomina um pequeno número de grandes latifúndios, diferentemente dos padrões registrados em outras partes do mundo, é fruto da desigualdade histórica de acesso à terra no país (LOWDER et al., 2016).

Em análise do Censo Agropecuário Nacional o MDA/DIEESE (2009) apresentou uma síntese das informações coletadas, mostrando a representatividade da agricultura familiar brasileira no contexto da agricultura nacional. Do total dos estabelecimentos da agricultura brasileira, 88\% pertencem à agricultura familiar, ocupando uma área total de 106,8 milhões de hectares, perfazendo um percentual de 23,3\% da área destinadas à agricultura no país.

Ainda que ocupe uma área pequena em comparação com a agricultura patronal ${ }^{5}$, a participação nos valores brutos da produção total é de $40 \%$ da produção gerada pelo setor da agropecuária nacional. Tal setor gera a ocupação de 16 milhões de pessoas, representando $79 \%$ do percentual de indivíduos ocupados no setor da agricultura. Esses números têm sua expressividade e importância para a geração de alimentos básicos para a população brasileira, inclusive, proteína animal. É a agricultura familiar a principal provedora.

\footnotetext{
${ }^{4}$ Segundo os autores esses países representam 96\% da população mundial, $97 \%$ da população economicamente ativa no setor agrícola e $90 \%$ das terras agrícolas no mundo (LOWDER et al., 2016).

${ }^{5}$ Segundo Altafin (2007), ao discorrer sobre a constituição do conceito de agricultura familiar, a noção de agricultura patronal se opõe a esse outro termo no que diz respeito ao tipo de mão de obra e gestão empregadas nas propriedades. Nesse sentido, o termo agricultura patronal tem seu funcionamento baseado na contratação de mão de obra e sua gestão é totalmente voltada para o mercado.
} 
Assim, a continuidade e existência dos bancos de sementes crioulas que asseguram maior autonomia aos camponeses na reprodução de seus sistemas de produção alimentares e que dizem respeito ao controle dos recursos genéticos e da biodiversidade passam a compor o rol de ações e práticas que podem ser descritas como fortalecedoras da soberania alimentar. Os movimentos ligados aos camponeses são pressionados cotidianamente a criar novas formas de resistências e estratégias para superar essa nova etapa do avanço do capital no campo. Uma dessas formas se expressa pela constituição de experiências de produção de suas próprias sementes em escala maior que permita a distribuição e comercialização para aqueles camponeses que não conseguem reproduzir as suas sementes e dependem do mercado das sementes transgênicas e híbridas das multinacionais.

No ano de 2004, o MPA elabora seu projeto político consubstanciado no documento intitulado "Plano Camponês". Segundo MPA (2012b), o Plano tem na sua base conceitual os seguintes elementos: camponeses, sistemas de produção camponês, agroecologia e alimergia. Sinteticamente, camponeses é um modo de ser e de estar no mundo e seus sistemas de produção foram desenvolvidos ao longo de sua história com independência de insumos externos e respeito à natureza, 'autônomo e soberano'. A agroecologia é considerada a base científica e técnica que vai permitir desenvolver e alcançar a soberania alimentar. É ainda considerada um conceito prático e político, envolvendo várias dimensões: ecológica, social, econômica, política e cultural.

Por fim, o conceito de Alimergia expressa os resultados da sinergia entre as interações produzidas na interfase entre plantas, animais, sol, chuva e vento e os sistemas de produção, produzidas na relação dos camponeses com a natureza, gerando alimentos, energia líquida, elétrica e gás, permitindo aos camponeses, autonomia e soberania (MPA, 2012b).

O Movimento constrói estratégias para operacionalizar o Plano Camponês por meio dos denominados Eixos Estruturantes. Este eixo estruturante está intrinsecamente ligado às famílias, comunidades e os territórios, onde as famílias camponesas estão inseridas, pois são elas as gestoras desse processo. O Plano compõe-se de seis eixos: produção, educação e formação, vida de qualidade, comunidade camponesa e soberania. É nesse eixo estruturante que se encontra o debate e a concepção de Soberania Alimentar.

Para o movimento a resistência ao sistema de dominação capitalista está fortemente ligada à construção de estratégias para a operacionalização da soberania alimentar. Pois é a soberania alimentar estruturada a partir dos elementos acima elencados - camponeses, sistemas de produção camponês, agroecologia e alimergia - que fundamentará e garantirá a permanência dos camponeses no território. Esse último entendido como o espaço 
historicamente ocupado pelos camponeses. E a produção de alimentos necessariamente tem que ser produzida localmente porque está vinculada a um modo de vida, a cultura de um povo, respeitando o equilíbrio ambiental (MPA, 2012b).

Tal soberania liga-se ainda às demais soberanias, a saber; hídrica, energética, genética e do território. É ela que vai garantir a permanência do modo camponês de viver e de produzir. Interessam aqui, em particular, as estratégias em torno da construção do processo de soberania genética que envolve o resgate, manutenção e conservação, melhoramento, produção e distribuição de sementes crioulas. Embora, essa estratégia esteja relacionada à soberania hídrica e territorial, pois sem água e terra para produzir não há como garantir soberania genética e alimentar. Terra e água são as condições primevas.

Desde 1996, o MPA desenvolve uma série de atividades em torno dessa temática que envolve o nível das famílias camponesas, das comunidades e o nível dos territórios, reunidos, no último período, no Plano Nacional de Sementes. Esse Plano avança no sentido de massificar o acesso ao acervo de sementes crioulas disponíveis, tanto pelas famílias camponesas, quanto pelas comunidades.

As famílias camponesas guardiães de suas sementes continua a ser o princípio dessa estratégia, mas ao dinamizar esse processo, objetivando constituir um polo de resistência ao avanço dos transgênicos nos sistemas de produção dos camponeses, o MPA inova com a instalação das UBS - Unidades de Beneficiamento de Sementes Crioulas. Tal estratégia dialoga com a campanha internacional da Via Campesina - As Sementes são Patrimônio dos Povos a Serviço da Humanidade. Assim, o MPA constrói uma experiência singular, tornandose referência para fazer frente à perda crescente da biodiversidade e, sobretudo, da memória biocultural do campesinato nacional.

Considerada hoje a maior Planta de Produção de Sementes crioulas em mãos dos camponeses na América Latina, a experiência com a implantação da UBS teve início pelo estado de Santa Catarina, no município de São Miguel do Oeste, administrada pela cooperativa Oestebio (COOPERATIVA, 2014).

Esse é um amplo e complexo processo de disputa, que envolve aspectos políticos e técnicos, perpassando a sociedade civil e as políticas de governo e, que certamente vem produzindo um rico processo de aprendizagens para o movimento e camponeses nele envolvido. A presente tese narra e analisa esse processo a partir da seguinte estrutura. 


\subsection{O PROBLEMA DE PESQUISA}

Como já assinalado a perda da agrobiodiversidade, representada pelo avanço do uso das sementes transgênicas, inclusive pelos camponeses em seus sistemas de produção, afeta a permanência dos modos de viver desse grupo social no campo. Essa perda representa uma crescente diminuição da autonomia na definição dos modos de produzir, aumentando a sua dependência de insumos externos, bem como colaborando no aumento da degradação ambiental, na medida em que são exigentes no uso de fertilizantes químicos e agrotóxicos que contaminam rios, solos e pessoas. $\mathrm{O}$ aumento dessa dependência representa ainda, no longo prazo, a perda da soberania alimentar, hídrica, genética e territorial. Essa realidade, que não é nova, tem se aprofundado por meio de formas de apropriação cada dia mais sofisticadas, aportada tanto pela ciência como por processos legais - Leis, Decretos, Portarias - e tem sido reiteradamente implementado pelas multinacionais do setor, com a colaboração direta do Estado, em prejuízo dos camponeses. Esse processo se constitui em um problema socioambiental do qual essa tese se debruça.

\subsection{A HIPÓTESE}

Partiu-se da hipótese que o processo de resistência exige a constituição de amplas alianças na perspectiva de influenciar camponeses, pessoas e instituições, políticas governamentais, bem como diversos processos com objetivo de apoiar e alterar a correlação de forças na implantação da soberania alimentar. Desse modo, ao analisar as experimentações sociais instituídas pelo MPA - tanto nos sistemas camponeses de produção quanto nos territórios onde estão inseridos - em torno de estratégias de resgate, conservação, produção, comercialização e distribuição de sementes crioulas e varietais, a seguinte hipótese foi elaborada e serviu como um guia no percurso da elaboração da pesquisa de campo, das leituras e revisões da bibliografia, bem como da narrativa que entrego.

i) o MPA influencia outras instituições, bem como políticas governamentais no sentido de apoiar e alterar a correlação de forças na implantação do projeto da soberania alimentar.

\subsection{OBJETIVO GERAL}

Considerando o problema de pesquisa e a hipótese, estruturou-se um objetivo geral que assim se expressa: analisar como o Projeto de Sementes do Movimento dos Pequenos 
Agricultores, no estado de Santa Catarina, no período de 2004 a 2014, influenciou a construção da soberania alimentar por meio de suas ações junto às instituições.

\section{MÉTODO, METODOLOGIA E INSTRUMENTOS DE PESQUISA}

Como instrumentos metodológicos fontes primárias e secundárias foram utilizadas, levando em consideração o referencial teórico da ecologia política, o tema da pesquisa, ou seja, a soberania alimentar e as questões condutoras dessa pesquisa, seus objetivos e hipótese. O estudo teve como foco o Projeto Sementes Crioulas do Movimento dos Pequenos Agricultores - MPA/Brasil. Atualmente o MPA atua em dezessete estados da federação brasileira, sendo que em alguns estados e municípios o projeto tornou-se referência para o conjunto do movimento, dos governos e da sociedade civil. Este é o caso do projeto desenvolvido no estado de Santa Catarina.

O formato da pesquisa inicial foi redefinido após a realização do primeiro trabalho de campo no estado de Santa Catarina que forneceu maiores elementos de como o processo estava organizado no território, quais os atores relevantes, quais os municípios a serem contemplados para além de São Miguel do Oeste - sede da cooperativa Oestebio - e a elaboração de um questionário específico para o diálogo com as instituições envolvidas. Nesse sentido, o universo de pesquisa foi redesenhado e realizado conforme descrito abaixo.

Com um universo de atores espraiados para além do território do Oeste catarinense, foi necessário realizar um recorte no grupo dos sujeitos da pesquisa, considerando a contribuição desses para o processo ora em apreço. Assim, para a realização das entrevistas, organizou-se dois grupos distintos com aplicação de questionários diferenciados, objetivando acercar-se das questões que orientou a pesquisa, da seguinte maneira:

$1^{\circ}$ ) Universo do MPA - incluiu dirigentes, assessores e técnicos da cooperativa Oestebio e do MPA; camponeses orgânicos ao movimento que participam da rede de guardiões e multiplicadores, incluindo aqueles que não estão ligados organicamente ao movimento, mas participa na rede como multiplicadores de sementes, contemplando na escala do tempo, os que iniciaram o processo e aqueles que foram integrados no decorrer do mesmo. Nesse universo, foram realizadas dezesseis entrevistas nos municípios de Anchieta, Palmitos e São Miguel do Oeste, no estado de Santa Catarina e no município de Hulha Negra, no estado do Rio Grande do Sul.

$2^{\circ}$ ) Universo das instituições - esse grupo de entrevistas foi realizado com pesquisadores, professores e gestores que estiveram envolvidos nas atividades de concepção, estruturação, 
implementação e acompanhamento do processo, quais sejam: Conab-MAPA, em Brasília; EPAGRI e UFSC, em Florianópolis-SC e EMBRAPA - Sede, em Brasília e Clima Temperado, em Pelotas, no Rio Grande do Sul, totalizando oito entrevistas.

O trabalho de campo foi realizado em etapas e períodos distintos, conforme a disponibilidade dos atores envolvidos. Assim, para as entrevistas com gestores foram realizadas três visitas à órgãos em Brasília, nos seguintes períodos: abril de 2015, setembro e novembro de 2016. Para a pesquisa de campo envolvendo lideranças do MPA, camponeses e guardiões, bem como pesquisadores e professores das instituições, nos estados de Santa Catarina - municípios de Anchieta, Palmitos e São Miguel do Oeste - e Rio Grande do Sul Hulha Negra e Pelotas - foram realizadas duas visitas, totalizando quinze dias, nos meses de maio, novembro e dezembro de 2016. Utilizou-se do roteiro de entrevista e questionário semiestruturado e quando autorizado pelo entrevistado o uso de gravador. Dessa forma, nem todas as entrevistas foram autorizadas a gravação e em alguns casos houve a solicitação do sigilo da fonte interlocutora. Nesse sentido, as entrevistas reproduzidas no presente texto resguardará a identidade dos entrevistados.

É importante ressaltar que do ponto de vista metodológico, o compromisso com a dinâmica do diálogo para constituir o corpus da narrativa por meio da entrevista-roteiro foi o caminho escolhido. Entende-se por diálogo, o sentido dado por Demo (1989) em que se busca 'um dado dialogado', é um ‘dado' produto do processo de discussão, discutido, construído em colaboração. Para tanto, foram elaborados dois roteiros distintos de entrevista cujo fio condutor se apoiou nas questões norteadoras da pesquisa, mas que não se ateve exclusivamente a elas, visto que o objetivo foi a reconstituição do processo histórico a partir dos depoimentos ou do testimonio ${ }^{6}$ dos atores aí envolvidos. Acredito no que afirma Demo (1989) que "[...] a profundidade do depoimento se ganha na discussão aprofundada, repetida, tranquila, retomada, arredondada, arraigadamente aberta, em contexto de diálogo dialético autêntico" (pg. 247).

Portanto, considero que os 'dados' coletados refletem a experiência dos indivíduos, mas, sobretudo, a experiência coletiva do movimento na sua prática diária e nos contextos de disputa política frente aos projetos hegemônicos. Portanto, como afirma Nunes (2011), os sujeitos realizam "[...] um ato de formação de identidade que é simultaneamente pessoal e coletivo [...]" (pg. 333).

\footnotetext{
${ }^{6}$ A noção de testimonio é apropriada ao contexto da presente pesquisa na expressão que lhe dá Nunes (2011), a saber: "[...] uma manifestação de uma autenticidade cultural baseada na experiência social da subalternidade, da dominação e da resistência, assumindo o pesquisador um papel de facilitador ou de 'parteiro' dessa experiência, conferindo-lhe uma forma que permita a sua publicação e partilha [...]" (pg. 333).
} 
A ecologia política oferece uma leitura de como a economia política afeta o acesso, o uso e a apropriação dos recursos naturais e seus efeitos socioeconômicos e ambientais. Nesse sentido, essa perspectiva entende que interações é o que ocorre no nível local e na sua rede de relações nos demais níveis, estadual, nacional e internacional. Assim, para melhor compreendê-las, precisam estar explicitadas e o diálogo entre diferentes disciplinas colabora na produção dessa compreensão. Além disso, o conceito geográfico de escala, no sentido de tempo e também do próprio espaço é fundamental nessa abordagem para ligar pessoas, ambientes e modos de vida (BLAIKIE, 1985).

Portanto, a narrativa ora apresentada orientou-se na produção de um texto que situasse o processo historicamente, nos contextos no qual o camponês, sujeito central dessa tese, foi produzido e se produziu, em diferentes escalas no tempo. Mas também historicamente foram situados as instituições e os debates com os quais o movimento foi obrigado a se inteirar, discutir e protagonizar. Desse modo, como salienta Ribeiro (2014) “[...] construir uma interpretação é atuar como agente social, é reproduzir os fatos com intencionalidade intencionalidade objetiva, que os documentos permitem consolidar como verossímil, até que se diga o contrário" (pg. 46).

O texto da tese está estruturado em quatro capítulos, assim organizados: o primeiro capítulo objetiva situar os conceitos que baseiam a leitura do processo, quais sejam, soberania alimentar, conflitos socioambientais e justiça ambiental numa perspectiva histórica e sua especificidade no contexto desse trabalho. O trio soberania alimentar - conflitos e justiça socioambientais serão reiterados no decorrer da narrativa, pois que eles descrevem situações e contextos vivenciados historicamente pelos camponeses no país.

No segundo capítulo, apresento uma leitura de estudos da ecologia política num diálogo com os estudos agrários, especialmente, da sociologia e geografia, sem o qual não seria possível retratar o legado histórico e atual da injusta estrutura de terra no país, produtora de fraturas socioambientais históricas. Além disso, situo o controverso debate da 'captura' da terra - por meio do land grabbing e green land - que envolvem aspectos da questão socioambiental contemporânea e da imposição de uma matriz tecnológica unívoca, a saber, o agronegócio. Todos esses processos se configuram como produtores de conflitos e injustiças socioambientais.

Situar historicamente a origem do movimento, o contexto, seus atores e as primeiras iniciativas que deram forma a experiência do MPA é o papel que cumpre o terceiro capítulo. Assim, o texto buscar situar o camponês no espaço concreto da experiência, apresentando informações relevantes do lugar onde vivem, o que produzem e como são distribuídos os 
recursos socioambientais no território. Além disso, situa o contexto institucional, produzido nas últimas décadas, que limita e constrange a estratégia do projeto de produção de sementes no cenário nacional e internacional.

O último e quarto capítulo narra propriamente a experiência de massificação de sementes, identificando os principais fatores envolvidos no processo e discutindo a luz da literatura consultada, da perspectiva dos conceitos de conflitos e justiça socioambiental, as evidências da capacidade do campesinato brasileiro de resistir por meio de alianças, descontruindo barreiras e constituindo políticas públicas para apoiar a continuidade da soberania alimentar. Por fim, nas conclusões, reitera-se os aprendizados dessa experiência que certamente é geradora de subsídios para outros processos de constituição de estratégias socioambientais de resistências. 


\section{CAPÍTULO I - SOBERANIA ALIMENTAR, ECOLOGISMO DOS POBRES E JUSTIÇA AMBIENTAL}

A presente pesquisa tem na ecologia política sua abordagem teórica. Este capítulo busca situar historicamente os principais conceitos mobilizados na presente tese, a saber, soberania alimentar, conflitos socioambientais e justiça ambiental a partir de uma leitura crítica baseada em uma revisão de literatura. $\mathrm{O}$ primeiro conceito foi constituído com uma revisão sistematizada a partir do conceito de soberania alimentar como vem sendo elaborado e sistematizado pelos movimentos sociais e pela academia. Os conceitos subsequentes foram considerados a partir de autores relevantes e fundadores do que se considera hodiernamente como o movimento da justiça ambiental e do ecologismo dos pobres.

\subsection{SOBERANIA ALIMENTAR}

Para compreender as estratégias socioambientais em torno do projeto de sementes do Movimento dos Pequenos Agricultores (MPA) entendo que a ecologia política no que diz respeito as noções de ecologismo dos pobres e justiça ambiental, bem como a noção de soberania alimentar colaboram no sentido de evidenciar aspectos que mobilizam esses atores e os mecanismos que limitam e permitem, ao mesmo tempo, o desenvolvimento de suas ações. Para tanto, nesse item será discutida a soberania alimentar, tema central dessa tese, a partir de uma revisão sistematizada da produção atual em torno de sua conceitualização e os mecanismos que vem sendo constituídos para a sua realização.

Segundo Edelman et al. (2014), embora não haja consenso sobre a origem do termo soberania alimentar, alguns o creditam a um programa do governo mexicano, mas certamente seu relançamento na agenda internacional se deve ao movimento camponês internacional, Via Campesina, por ocasião da realização da Cúpula Mundial para a Alimentação (CMA), em 1996, realizada em Roma, pela Organização das Nações Unidas para a Alimentação e Agricultura $\left(\mathrm{FAO}^{7}\right)$. Ocasião em que se produziu mais um acordo multilateral com prejuízos aos países em desenvolvimento (CHAIFETZ; JAGGER, 2014).

Por outro lado, o termo distancia-se do outro, segurança alimentar formulado no âmbito da FAO que discute e organiza as políticas e programas que objetivam garantir a redução da fome, em especial, nos países em desenvolvimento. Chaifetz e Jagger (2014), ao

\footnotetext{
${ }^{7}$ Food and Agriculture Organization (FAO), sigla em inglês.
} 
elaborarem uma revisão dos últimos 40 anos sobre o tema soberania alimentar, iniciam discutindo como esse órgão das Nações Unidas concebeu, nos últimos anos, o enfrentamento da fome no mundo a partir da compreensão de que a resolução desse problema estaria na autossuficiência alimentar, alcançada por meio do aumento da produção de alimentos, via a chamada 'Revolução Verde'.

Nessa esteira, apoiou o desenvolvimento de largos programas governamentais para a implementação de programas institucionais de melhoramento de plantas por meio da instalação do arcabouço institucional (empresas públicas de pesquisa) com prejuízos à manutenção dos sistemas de produção camponeses e o fortalecimento da agricultura industrial, em larga escala, que se alastrou, desde a década dos 1950, pelos países em desenvolvimento, em todo o mundo. Exemplos desse processo são os programas de melhoramento de arroz, nos países asiáticos; programas de melhoramento de milho, nos países latinos americanos, entre outros (CHAIFETZ; JAGGER, 2014).

Os beneficiários desse largo e longo processo foram, em especial, as empresas multinacionais que passaram a obter acesso aos recursos genéticos anteriormente pertencentes aos camponeses. Assim descreve Shiva (2003) que testemunhou tal acontecimento na Índia.

De acordo com Edelman et al. (2014) o paradigma da soberania alimentar, cunhada pela Via Campesina, relançou vários aspectos críticos com relação aos sistemas alimentares em curso para além do debate da oferta adequada e suficiente de alimentos para os povos. Com uma ampla agenda, cuja ação está centrada em seis princípios guias, quais sejam: alimentar as pessoas; valorizar quem produz os alimentos; desenvolver sistemas alimentares locais; controle e acesso aos recursos naturais às populações locais e trabalhar respeitando a natureza. Dessa forma, o movimento traz para si a construção de uma nova forma de pensar a soberania alimentar por meio da criação de alternativas que substituam o sistema de agricultura atual que vê o alimento como mercadoria (CHAIFETZ; JAGGER, 2014).

Em que pese os conceitos sirvam para dar clareza e marcar diferenças sobre exatamente do que se fala, Hopma e Woods (2014) chamam a atenção para um fato que expressa a própria existência da Via que é a forte presença da diversidade na composição dessa articulação internacional que abriga diversas culturas e povos em um mesmo movimento, unindo continentes, cores e etnias. Nesse sentido, para o movimento o conceito está se fazendo, ele é um processo, composto por um conjunto de alternativas que em cada lugar expressa a sua própria dinâmica e possibilidade, cujo fio condutor se assenta nos seis princípios acima arrolados. 
De certo a soberania alimentar tornou-se uma temática que perpassa várias disciplinas o que obriga uma abordagem interdisciplinar daqueles que desejam observá-la tanto do ponto de vista epistemológico quanto prático. Wittman (2011) partindo de uma revisão de literatura interdisciplinar baseada, sobretudo, na ciência agroecológica e social discorrendo sobre o tema, questiona se o conceito não reivindica uma nova estrutura de direitos relacionada à alimentação e a natureza. A autora confirma que, inicialmente, foi o movimento social internacional camponês que cunhou e formulou os primeiros documentos acerca do conceito e das práticas que envolvem a soberania alimentar.

Muito recentemente, a academia se voltou para teorizar e tentar compreender as práticas e os reclames dos movimentos. Assim descreve Wittman (2011): "Much of the most recente literature takes a world-historical and food-regime approach studies and its practical implications for addressing food and environmental crises" (pg. 88). A autora ainda sugere que subjacente a essa abordagem está uma nova estrutura de direitos à alimentação e uma nova cidadania agrária, na medida em que pressupõe a existência do direito a escolher e não apenas, ter acesso ao alimento. Sobretudo, escolher o quê, como e onde produzir e comercializar os alimentos que consomem, estabelecendo o espaço local, onde produtores e consumidores vivem, como o território para a realização da soberania alimentar. A maior parte dos camponeses que compõem o movimento provém de países com histórias seculares no desenvolvimento da agricultura. Nesse sentido, não há como 'negociar' seus modos de vida. Desse modo, afirmam os camponeses na Conferência Mundial pela Soberania Alimentar, realizada em Mali, no ano de 2007:

A soberania alimentar é um direito dos povos a alimentos nutritivos e culturalmente adequados, acessíveis, produzidos de forma sustentável e ecológica e o direito de decidir o seu próprio sistema alimentar e produtivo. Isto coloca aqueles que produzem, distribuem e consomem alimentos no coração dos sistemas e políticas alimentares, acima das exigências dos mercados e das empresas. Defende os interesses das gerações actuais e futuras. Oferece-nos uma estratégia para resistir e desmantelar o comércio livre e corporativo e o regime alimentar atual (...) supõe novas relações sociais livres de opressão e desigualdades entre homens e mulheres, grupos étnicos, classes sociais e gerações (DECLARAÇÃO DE NYÉLÉNI, 2007, pg 1-2).

Por outro lado, o crescente interesse pela abordagem da soberania alimentar, do ponto de vista de acadêmicos e de agências internacionais, segundo vários autores (Hopma e Woods, 2014; Wittman, 2011; Harvey e Pilgrim, 2011; Hanjra e Qureshi, 2010) está diretamente relacionada ao aumento das diversas crises porque passam os sistemas alimentares no mundo, com efeitos dramáticos, especialmente, nos países em 
desenvolvimento, caso nenhuma mudança seja operada e se confirmem as projeções dos efeitos do aquecimento global provocados pela mudança do clima. Tais crises dizem respeito:

i) à crise ambiental, envolvendo, a degradação, a escassez e a disputa pelos diversos tipos de recursos naturais como terra, água, solo, florestas e a biodiversidade aí envolvida;

ii) à crise dos alimentos, em virtude do aumento dos preços dos produtos agrícolas, provocada pelo avanço dos efeitos das mudanças climáticas, especialmente as secas nos países considerados produtores de alimentos, como Austrália e Estados Unidos da América; pela diminuição e substituição da área de plantio de culturas alimentares por culturas geradoras de energia - os chamados biocombustíves; e pela alta dos preços dos combustíveis;

iii) às crises sociais, econômicas e políticas, decorrentes em grande medida dos ajustes neoliberais e dos acordos agrícolas realizados pela $\mathrm{OMC}^{8}$, que afetam os camponeses em diversas partes do mundo em desenvolvimento, em função do avanço crescente da ação das empresas multinacionais, especialmente, nesses países pelo controle de seus sistemas alimentares, especialmente, por meio da regulamentação do acesso as sementes, entre outras pressões.

No conjunto tais crises aprofundam problemas clássicos como a fome, a pobreza e a desnutrição. Para além dessas crises, há projeções sobre os efeitos das mudanças climáticas que afetarão a disponibilidade e a produção de alimentos ao redor do mundo, especialmente, em áreas que serão mais fortemente afetadas. Segundo Hanjra e Qureshi (2010), ainda que esses impactos sejam pequenos do ponto de vista da produção global de alimentos, ele terá distribuição geográfica desigual, afetando majoritariamente as regiões áridas e subúmidas dos trópicos, na África e no sul Asiático, em especial nos países pobres.

Para Harvey e Pilgrim (2011), a disputa será concentrada no acesso e uso da terra pelo que eles denominam trilema ambiente - energia - alimento, ao menos, nas principais regiões produtoras de biocombustíveis como Brasil, Estados Unidos e Europa. Não há nenhum substituto imediato, até o presente, aos combustíveis fósseis, com exceção dos agrocombustíveis, que exigirá certamente, o aumento de área para a ampliação do plantio com esta finalidade, disputando áreas destinadas a produção de alimentos.

Além disso, há dados estruturais sobre a já crescente ocupação das áreas com culturas e pastagens no mundo; as tendências e previsões para o aumento da população mundial; da

\footnotetext{
${ }^{8}$ Organização Mundial do Comércio (OMC); World Trade Organization (WTO) - sigla em inglês.
} 
fome e da subnutrição, todos dados de dimensões gigantescas, impossíveis de visualizar. Por essas previsões, haverá enormes lacunas entre as necessidades e as disponibilidades, como diriam os economistas, entre a demanda e a oferta, tanto de área para cultivar como alimentos para ofertar.

De acordo com Laurance, Sayer e Cassman (2014), com a demanda crescente por mais alimentos, o aumento das áreas cultivadas seja com produção de alimentos, pastagens ou agrocombustíveis, em função das previsões do aumento da população mundial - 9 bilhões até 2050 e até o final deste século, 11 bilhões -, serão os ecossistemas tropicais, as regiões que sofrerão as maiores pressões, tanto no aumento da área cultivada quanto no número da população, por conta disso a biodiversidade estará fortemente ameaçada.

Quando se fala em aumento da área agricultável trata-se da mobilização de outros recursos e infraestrutura para operar o tipo de agricultura da qual Laurance, Sayer e Cassman (2014) se referem, a agricultura de larga escala. E as previsões é que esse crescimento se dará especialmente, na América do Sul e na África Sub-Saariana, cujos solos são frágeis para suportar a matriz tecnológica que a agricultura de larga escala exige, a saber - insumos exigentes em combustíveis fósseis e eletricidade, vias de transporte para carrear altas produções, complexos sistemas de irrigação e sementes transgênicas. Projeta-se que para cobrir uma demanda nessa magnitude, será necessária uma área do tamanho do Canadá.

Outro recurso altamente alterado nas últimas décadas, em função do desenvolvimento desse modelo agrícola em expansão, são os solos, considerado um recurso chave no conjunto dos fatores que afetam a oferta e a produção de alimentos. Para Hurni et al. (2015) para além da água, energia e terra, os solos compõe o conjunto de elementos no debate sobre agricultura e segurança alimentar. Obviamente que a problemática do manejo e degradação dos solos vai muito além do setor agrícola, tanto o é, que a Organização das Nações Unidas (ONU) decretou o ano de 2015, como o Ano Internacional dedicado a esse recurso (FAO, 2015).

Os solos são a base de sustentação, literalmente falando, da vida na terra. Importante para as cidades e, essencial e fundante, para o desenvolvimento da agricultura estando, direta ou indiretamente, entre os desafios e objetivos dos Objetivos de Desenvolvimento Sustentável (ODS) das Nações Unidas. Aproximadamente 95\% da produção agrícola global ocorrem nos ecossistemas terrestres e usam o solo como base de sustentação. E por isso mesmo, problemas como erosão (provocado pela ação das águas e dos ventos), compactação, poluição e diminuição da matéria orgânica dos solos estão diretamente relacionados com o desenvolvimento e a intensificação da agricultura industrial e, necessitando urgentemente serem revistos, na medida em que a conservação e manejo dos solos terão papel central na 
oferta de serviços ecossistêmicos e na mitigação dos efeitos das mudanças climáticas (HURNI et al., 2015).

Considerando que grande parte dessa população ocupará as áreas urbanas, a maioria das paisagens será de metrópoles e cidade inchadas. Com impactos de magnitudes pouco mensuráveis, mesmo com as previsões/simulações do Painel Intergovernamental de Mudanças Climáticas (IPCC) que ainda não apresentam acúmulo de conhecimentos suficiente para a previsão dos efeitos nas escalas regionais e locais (PELLEGRINO; ASSAD; MARIN, 2007).

Com uma matriz tecnológica altamente dependente de sistemas irrigados e, mesmo a agricultura dependente da oferta da água das chuvas, a chamada agricultura de sequeiro, o aquecimento global representa um impacto significativo na oferta hídrica em conjunto com a demanda por outros usos, inclusive o consumo humano. Segundo Hanjra e Qureshi (2010), as políticas alimentares necessitam urgentemente considerar a escassez hídrica como uma realidade presente.

Há uma enorme lacuna entre a disponibilidade de água e sua demanda. De acordo com esses autores, a escassez hídrica já é uma realidade para mais de meio bilhão de pessoas e as estimativas são de que até 2025 essas grandezas alcancem três milhões de pessoas vivendo sob condições de estresse hídrico ou escassez. A agricultura irrigada, responsável sozinha pela oferta de $40 \%$ dos alimentos no mundo, utiliza $80 \%$ da água global. Os outros $60 \%$ da oferta de alimentos corresponde à participação da agricultura de sequeiro. Além disso, muitas das fontes de água disponíveis no mundo estão poluídas. Assim, a crise hídrica tende a intensificar as demais crises acima arroladas, na medida em que está profundamente intricada com as formas de viver e estar no mundo, em especial, com os sistemas de produção alimentares atualmente desenvolvidos ao redor do globo, pautado majoritariamente na agricultura de larga escala, o agronegócio (HANJRA e QURESHI, 2010).

Com o avanço dos estudos que combinam projeções e simulações, utilizando-se de modelos matemáticos e, a partir dos dados gerados pelo IPCC, considera-se que, com os efeitos das mudanças climáticas, a tendência é a deterioração dessa situação com impactos diretos sobre a produção de alimentos. Simulações feitas para a agricultura brasileira por Pellegrino, Assad e Marin (2008) e, sistematizados no trabalho de Girard (2008), apontam para uma nova geografia da agricultura no país com mudanças significativas tanto para a agricultura desenvolvida pelo agronegócio, quanto pela agricultura familiar camponesa, caso não haja mudanças significativas nas formas de manejar a natureza. Nesse sentido, duas das culturas representativas desses sistemas de produção, a soja, para o agronegócio e a mandioca, 
para a agricultura familiar, apresentam mutações significativas, geradoras de efeitos sociais, econômicos e ambientais. A cultura da mandioca, fortemente presente na agricultura familiar camponesa do semiárido brasileiro, será deslocada para o sul do país e a soja terá redução drástica em seu cultivo, conforme essas projeções.

Apesar desses cenários, a humanidade ainda tem o poder de escolha, e portanto, redirecionar os caminhos trilhados até aqui é o que o movimento da soberania alimentar propõe. Os movimentos sociais ligados ao campesinato internacional estão gerando experiências inovadoras na perspectiva de instituir e ampliar formas respeitosas de lidar com a natureza, os sistemas agroecológicos e o conjunto de práticas que anima o debate em torno do conceito de soberania alimentar, em processo de construção, mostram claramente que há outros caminhos possíveis. Visibilizá-los, conhecê-los por dentro para identificar suas virtudes e fragilidades, tornam-se imprescindíveis para àqueles que acreditam que modificações no fazer dessa prática milenar, a agricultura, poderão ser realizadas hodiernamente, garantindo assim o presente e o futuro do elemento humano na terra.

O apelo para a mudança de perspectiva não vem só do movimento, durante o Fórum de Mudanças Climáticas, realizado em fevereiro de 2015, em Paris, o diretor-geral da FAO, José Graziano da Silva declarou: "O modelo agrícola de produção que predomina hoje não é adequado para responder aos novos desafios da segurança alimentar no século 21 e nem à necessidade de uma produção sustentável, inclusiva e resiliente" (GREENPEACE, 2015).

Há pelo menos três dimensões determinantes envolvidas no debate sobre a soberania alimentar, uma dimensão política que envolve a tomada de posição do Estado e da sociedade civil organizada para garantir uma transição a outro modo de relação da humanidade com a natureza; dos homens com outros homens e com as mulheres; uma dimensão técnica que permita operar uma mudança na matriz tecnológica atual que respeite a relação com a natureza e diminua sobremaneira o controle das empresas sobre o manejo dos sistemas produtivos e alimentares dos camponeses e consumidores e por fim, e totalmente dependente dos outros dois, uma dimensão territorial que diz respeito à permanência da massa de camponeses no campo, a soberania do espaço. Todas essas dimensões às questões de manejo dos recursos (água, solo, terra, biodiversidade) estão presentes.

Segundo Kloppenburg (2014), considerando o papel que desempenham as sementes na reprodução social dos sistemas alimentares dos camponeses e no funcionamento da agricultura, bem como o contexto crescente da captura das grandes corporações da soberania dos campeneses sobre suas sementes por meio da apropriação dos recursos genéticos das plantas, do poder do monopólio da indústria do setor de sementes, do desenvolvimento das 
culturas transgênicas e da imposição global dos direitos de propriedade intelectual sobre esses recursos, a questão da soberania genética ou das sementes deve ser considerada como parte estruturante da soberania alimentar.

Analisando os manifestos de duas das principais organizações no âmbito internacional que vem se debruçando na luta global contra as multinacionais do setor, a Via Campesina e a Navdanya ${ }^{9}$, Kloppenburg (2013) identifica as seguintes dimensões que compõe a soberania das sementes ou a soberania genética reivindicada por esses movimentos: o direito de guardar e replantar as sementes que garante a autonomia camponesa; o direito de compartilhar, receber e trocar sementes de outros camponeses que fundamenta a própria possibilidade de aumentar a diversidade genética; o direito de usar as sementes e gerar novas variedades, garantindo assim a universalidade na produção do conhecimento e o direito de participar na definição de políticas sobre sementes que garanta a preservação da soberania dos camponeses sobre os seus recursos.

Suárez (2013) identifica que ao redor do mundo diversos movimentos sociais rurais tem evocado a abordagem dos direitos humanos como uma estratégia importante para organizar as suas lutas contra o avanço da expropriação do capital contra o acesso e controle dos recursos socioambientais. Acostumados a serem visibilizados pela organização, mobilização e condução de ações diretas como os protestos, ocupações, marchas entre outras, essa nova abordagem é menos visível, mas muito significativa para essas organizações que estão usando as estratégias legais para ampliar suas estratégias políticas mais gerais. Dentre os exemplos estão as organizações locais, nacionais e internacionais de camponeses, mulheres camponesas, pescadores artesanais, populações indígenas, trabalhadores rurais sem terra e populações tradicioanis em diversos países. As razões para essa inovação, de acordo com as informações coletadas pela autora é que: "[...] the human rights framework is perceived as an alternative strategy of resistance to violent protest or armed struggle which is likely to gather the support of other sectors of society in the face of government repression"(SUÁREZ, 2013, pg. 242). Essa é uma das razões, mas não a única para explicar porque essa abordagem tem se tornado um caminho nas estratégias dos movimentos sociais rurais.

Para a autora o contexto internacional e local também é um fator determinante para que essa abordagem tenha tomado tal abrangência. A globalização neoliberal tem produzido mutações nas legislações internacional e nacionais com relação às questões agrárias,

\footnotetext{
${ }^{9}$ Navdanya é uma organização não governamental, sediada na Índia, que trabalha com a conservação da biodiversidade, agroecologia, direitos dos agricultores e processos de resgate de sementes, fundada desde 1987. Formulou a campanha internacional Seed Freedom. Dentre seus ativistas mais conhecidos mundialmente está a Dra. Vandana Shiva (www.navdanya.org). Última consulta 31.03.2018.
} 
especialmente no tocante as sementes com a imposição do tratado de propriedade intelectual produzido no âmbito da Organização Mundial do Comércio. Nesse novo cenário, os mais pobres com menos ou nenhum acesso ao poder, perdem invariavelmente.

Suárez (2013) lembra ainda que essa abordagem ancorada nos direitos humanos apresenta limites. Certamente, o contexto onde ela se insere é muito importante, mas sobretudo, o status atual do desenvolvimento da sua própria estruturação comparada à outros regimes de proteção como por exemplo, os regimes de proteção para o investimento e comércio, os quais apresentam mecanismos e instrumentos de proteção e sanções acabam se sobrepondo, em especial, no que se refere aos camponeses. Esses regimes não aceitam a primacia da lei dos direitos humanos internacional.

A questão da soberania das sementes está diretamente relacionada com direitos econômicos, socioambientais e culturais e não expressamente com direitos humanos, como explicita Suárez (2013):

[...] the issues raised in the defense of the peasants' seeds and the associated knowledge are undoubtedly related to the right to adequate food, the right to work, to develop own's one culture and knowledge and the right to self-determination and to freely dispose over natural resources (pg. 245).

Parece não haver conexão entre os direitos humanos e os demais direitos, a grande maioria dos Estados nações não dialoga com os tratados internacionais nessa área. Além disso, os direitos humanos não são estruturas autônomas, não tem aplicabilidade isolada das leis domésticas e outros regimes. Portanto, o problema da profícua produção de regimes, normas e regulamentações que se sobrepõe sobre um mesmo tema, cuja hierarquia de aplicabilidade gera desvantagens para àqueles que não têm elementos de poder ou possuem pouco desses elementos, nas arenas decisórias, vem produzindo efeitos danosos, especialmente para as populações que vivem da agricultura. A perda da soberania das sementes dos camponeses torna-se um caso modelar nesse cenário (SUÁREZ, 2013).

Como pode ser constatado nos trabalhos de Kloppenburg (2004, 2014), historicamente as multinacionais do setor atuam na arena da batalha legal para retirar direitos, impor suas regras e garantir seus lucros. Vejamos a síntese que faz o autor em um artigo que traz um título bastante sugestivo ${ }^{10}$ :

\footnotetext{
${ }^{10} \mathrm{O}$ título do artigo em inglês: "Re-purposing the master's tools: the open source seed initiative and the struggle for seed sovereignty" (KLOPPENBURG, 2014) que traz um debate das estratégias que o movimento na América do Norte vem instituindo, reunindo melhoristas públicos e privados, agricultores melhoristas, ativistas e intelectuais acadêmicos sobre a utilização de leis e contratos na perspectiva de diminuir a ação do monopólio das grandes corporações do setor, tanto no patenteamento de germoplasmas de plantas, mas sobretudo, das tecnologias e métodos de melhoramento que permitem que essas empresas restrinjam e limitem o livre acesso tanto aos recursos naturais quanto aos processos de produção do conhecimento. Assim, advogam que fazer uso
} 
[...] for the capital the law has been a consistent and powerfull mechanism for commodification of the seed in the United States, in Europe and globally. As early as the 1890, seed companies in the US had begun agitating for application of intellectual property rights to new crop varieties. In 1930, they settled for a Plant Patent Act covering some asexually reproducing species. European seed companies, no less interested in the commoditification of germplasm than their American counterparts, introduced patent-like 'plant breeders' rights' (PBR) through the creation of the Union for the Protection of New Varieties of the Plants (UPOV) in 1961. UPOV became both the model and justification for passage of the similar US Plant Variety Protection Act (PVPA) in 1970. A major difference between US and European approaches to restricting farmers' access to germplasm has been the use in the European Union (EU) of a 'Common Catalogue' which has prohibited the exchange or sale of any but the officialy approved and listed cultivars (Bocci 2009). In the US, the seed industry vigorously opposed application of varietal quality standards or limitations on its marketing strategies (KLOPPENGURG, 2014, pg. 1227-1228).

Certamente que esses processos que possibilitaram e legitimaram a mercadorização das sementes dos camponeses, amplamente reconhecidas e analizadas, servem para muitas lições, inclusive que esse é um campo que deve ter atuação constante dos movimentos sociais. Assim, as experiências internacionais relatadas por Suárez (2013) no campo da constituição da soberania genética organizadas pelos movimentos sociais rurais apontam para ações no campo da constituição de direitos para influenciar a elaboração de normas nacionais que protejam os camponeses, suas sementes e recursos e sobretudo, os conhecimentos a eles associados.

Italian peasants have also been successful in defending a space to continue developing peasant varieties of seeds, to revalorize peasant knowledge and to protect agrobiodiversity. The militant legal strategy has been important in this struggle because the regulatory framework on seeds was completely biased in favor of the seed industry making illegal peasants' of saving and exchanging seeds out of the market (SUÁREZ, 2013, pg. 249).

Os esforços da própria Via Campesina na articulação para aprovação da Convenção Internacional sobre os direitos dos agricultores é outro exemplo concreto nessa direção. Para além dessas iniciativas, a Via vem orientando a constituição de experiências que fortaleçam as práticas já em uso pelos camponeses, quais sejam, as casas de sementes comunitárias, o reforço para o desenvolvimento da agroecologia como matriz tecnológica e a ampliação e busca de aliados comprometidos com os princípios que orientam as suas ações. Isto porque os

dos mesmos instrumentos, no caso as leis e contratos, que essas empresas fazem em um formato que assegurem princípios que resguardem a liberdade de uso, criação e compartilhamento tornou-se na realidade norte americana um caminho possível por meio dos sistemas de código aberto espelhado no movimento de software livre. Não há consenso sobre o potencial dessa alternativa para a realidade dos países do Sul global, sobretudo porque a plataforma das organizações do Sul - a Via Campesina - possue um componente político que inclui expressamente a oposição aos direitos de propriedade intelectual e aos transgênicos. O autor participa diretamente como membro da organização instituída nesse processo denominada de Open Source Seed Initiative (OSSI). 
desafios atuais tem sido buscar alternativas para atuar nessa realidade de restrições e captura da soberania das sementes. Para tanto, construir alianças para além do campo do próprio movimento tornou-se imperativo, como Suárez (2013) salienta, analizando a ação do movimento nas arenas das estratégias legais:

[...] requires larger and more complex levels of organization because it builds on broader aliances among diferente actors, for instance, peasants, consumers, law professionals, policy markers and scientists; and on the capacity to simultaneously operate at diferente levels and arenas of action" (pg. 248).

Para o caso do Brasil em particular, movimentos sociais do campo, como o MST e o MPA, vem constituindo experiências concretas na direção que aponta a Via Campesina no intuito de construir a soberania alimentar assim reivindicada, incluindo, experiências práticas de produção de sementes para a inserção nos mercados institucionais, de orgânicos e outros.

Em que pese à noção de soberania alimentar seja uma noção-conceito ainda em construção, portanto, aberto, funcionando como um "guarda-chuva" - mobilizando uma amplitude de escalas e realidades, de ações e de sujeitos - compreendo a partir das leituras realizadas que no contexto da dinâmica desta pesquisa, essa noção pode ser apropriada como um conceito utopia, no campo do ideal, bem mais que um conceito normativo. A partir dessa plasticidade, ele acolhe uma diversidade de experiências denominadas aqui de 'resistências'. Nesse quadro, as ações que pretendem reconstruir os estoques de sementes dos camponeses sua autonomia - compõe um dos repertórios da soberania alimentar e da soberania das sementes conforme definida e discutida neste texto.

É importante ressaltar que o Projeto Nacional de sementes do MPA se insere nesse contexto dos processos acima descritos, dialogando com os repertórios e experiências internacionais do movimento da soberania alimentar e da soberania genética, mas guarda uma particularidade no que diz respeito a uma estratégia de ação política que envolve a massificação da produção de sementes em escala para comercialização e distribuição numa perpectiva de disputa territorial com a produção de sementes comerciais do agronegócio. Portanto, configura-se como uma experiência concreta demarcatória de espaço nos territórios da política, do mercado e da paisagem com potencial para compor um novo repertório para além das estratégias legais e institucionais no campo da soberania alimentar.

\subsection{AS CORRENTES SOCIOAMBIENTAIS}

Ao tratar sobre as correntes socioambientais, realizei um recorte a priori levando em consideração a realidade da história do campesinato brasileiro, notadamente marcada pela 
disputa pela posse da terra, não apenas nas áreas de colonização antiga, mas sobretudo, nas áreas de fronteiras ${ }^{11}$.

Nesse sentido, a Ecologia Política tem historicamente apresentado características chaves que a torna um campo por excelência interdisciplinar, não somente a transição entre as ciências sociais e naturais, mas, sobretudo, seu conjunto de 'ferramentas' originados da geografia, tendo o conceito de escala como central, o qual combina tempo e espaço em diferentes níveis a fim de compreender o processo histórico-dialético dos fenômenos socioambientais. Dessa maneira, esse conceito permite observar a diversidade dos fatos e acontecimentos na dinâmica real das sociedades em seus diferentes níveis, desde o indivíduo, suas comunidades, região, país e o sistema mundo para alcançar a complexidade de interações que aí ocorrem (BLAIKIE e BROOKFIELD, 1987; WATTS e PEET, 2004; ROBBINS, 2011).

A ecologia política tem recebido influência direta tanto dos objetos estudados quanto das abordagens que seus pesquisadores têm escolhido desde o princípio, centrada marcadamente pela economia política, mas antenada com o seu tempo, vem instituindo dialógos frutíferos com temas emergentes da sociedade atual (BRYAN e GOODMAN, 2008). Assim vejamos a síntese que os autores apresentam sobre essa produção:

The result has been an eclectic literature addressing a wide array of topics and theoretical debates including those linked to gender relations (ROCHELEAU et al., 1996; SCHROEDER, 1999), the cultural politics of development (PERREAULT, 2001, 2003a), science (FORSYTH, 2003; STOTT and SULLIVAN, 2000), nongovernmental organisations and social movements (BEBBINGTON, 2004b; BRYANT, 2005; FORSYTH, 1999), globalization (BEBBINGTON, 2001, 2004a; PERREAULT, 2003b), urban-rural dynamics (SWYNGEDOUW, 2004; SWYNGEDOUW and HEYNEN, 2003), the effects of warfare (LE BILLION, 2001, 2004), "rural trade networks" (MCSWEENEY, 2004), and middle-class 'ethical' consumption (BRYAN and GOODMAN, 2004; GOODMAN, 2004) (pg.711).

Ainda que a ecologia política tenha ampliado suas fronteiras, considero que o trabalho em torno do projeto nacional de produção de sementes do MPA aproxima-se mais da primeira fase da ecologia política onde a centralidade recai sobre a compreensão do movimento da economia política e as relações socioambientais aí produzidas. A ecologia política parte da compreensão que os processos ecológicos não podem ser compreendidos fora dos contextos de relações de produção local e do sistema econômico mais amplo. Portanto, essencial para

\footnotetext{
${ }^{11}$ Fronteira entendida como definiu Becker: “[...] é o espaço da expectativa de reprodução ampliada para praticamente todos os atores em jogo, mas onde há incerteza quanto a essa reprodução, na medida em que as ações sociais respondem à orientações políticas e valorativas e não só aos constrangimentos econômicos [...](pg. $67)$.
} 
observar as relações socioambientais atuais em que estão inseridos os camponeses e seus movimentos na disputa com a produção do agronegócio no país.

A escolha pela abordagem da ecologia política, focada no "Ecologismo dos Pobres" concebido por Martínez-Alier e na Justiça Ambiental, baseia-se na compreensão de que essa leitura permite reposicionar/atualizar a disputa em torno da agrobiodiversidade e de novos conflitos frente às dinâmicas atualizadas do capital no campo.

Para caracterizar o ecologismo dos pobres Martínez-Alier (2007, 2010, 2012, 2014b) distancia-se dos dois ambientalismos que marcaram a emergência da natureza como uma questão central para a humanidade nas últimas décadas. Esses dois movimentos, denominados por este autor como o 'culto ao silvestre' e o 'evangelho da ecoeficiência' distanciam-se do ecologismo ou ambientalismo dos pobres pela não crítica ao sistema econômico em vigor ou ao metabolismo social ${ }^{12}$ que o engendra.

A primeira corrente caracteriza-se pela defesa e proteção da natureza como um espaço de contemplação, refúgios intocados de fragmentos de ambientes considerados originais. Sua referência fundadora é John Muir e sua associação Sierra Club, criada em 1892, na cidade de São Francisco, no estado da Califórnia, nos Estados Unidos. De acordo com Martínez-Alier (2007) a base científica a partir da qual essa corrente se estruturou foi a biologia da conservação, que partindo da biologia descritiva derivou para a conservação normativa. Dentre suas principais realizações no campo da política ambiental estão: a Convenção da Biodiversidade, de 1992, na Conferência do Rio de Janeiro, e a Lei de Espécies em Perigo dos Estados Unidos.

No campo científico construiu conceitos e teorias tais como hot spots, espécies cruciais e o índice Apropriação Humana da Produção Primária Líquida ou da Produção de Biomassa (AHPPL). Para além dessa produção, essa corrente ambientalista recorre à motivação estética, utilitária e, certas vezes, ao sagrado. Dessa corrente deriva o movimento intitulado 'ecologia profunda' cuja centralidade de sua proposta política recai sobre a criação de reservas naturais como os parques naturais ou nacionais, cuja ausência do elemento humano seria seu desenho ideal (MARTÍNEZ-ALIER, 2007). Essa é uma das correntes de maior visibilidade midiática em virtude da atuação de grandes organizações internacionais como a Worldwide Fund of Nature (WWF) e a Nature Conservancy of Nature (IUCN ${ }^{13}$ ).

\footnotetext{
${ }^{12}$ Metabolismo social é entendido como uma das formas que se pode descrever a economia de uma sociedade a partir de seus indicadores físicos, como os materiais utilizados e a energia dispendida no processo produtivo (MARTÍNEZ-ALIER, 2014a).

${ }^{13}$ IUCN - União Internacional para a Conservação da Natureza. Site: http://www.iucn.org/.
} 
O evangelho da ecoeficiência preocupa-se com a produção dos impactos ambientais provocados pelas atividades industriais, da urbanização e da agricultura moderna. Com um repertório bastante peculiar para denominar a natureza, os defensores da ecoeficiência percebem-na como um recurso, um capital e ou um serviço, adicionando-lhe os adjetivos de natural ou ambiental. Agrônomos e economistas compõem esse ambiente cujo foco é a utilidade e a eficiência técnica, onde a noção de sacralidade não comparece. Com diversas ramificações no campo científico, como citado por Martínez-Alier (2007), desde a engenharia florestal até a saúde pública, o credo da ecoeficiência tornou-se quase universal na Europa e nos Estados Unidos da América.

Dessa corrente proveem grande parte dos conceitos que se tornaram glossário difundido nos debates ambientais através do globo. Dentre os mais difundidos estão: desenvolvimento sustentável na sua versão de crescimento econômico; a fórmula win-win ganhos econômicos e ganhos ecológicos - e a modernização ecológica ${ }^{14}$. Assim afirma Martínez-Alier (2007): “A modernização ecológica caminha sobre duas pernas: uma econômica, com ecoimpostos e mercados de licença de emissões; a outra, tecnológica, apoiando medidas voltadas para a economia de energia e de matérias-primas” (pg. 28).

A Economia Ambiental e a Ecologia Industrial são os espaços da ciência que dão base para o desenvolvimento de estudos relacionados ao melhor gerenciamento da degradação dos processos produtivos. Estudos relacionados com o uso de matérias-primas e energia na economia atual são valiosos tanto para esta corrente como para os estudos do metabolismo social que sustentam a instituição do ecologismo dos pobres. Para o autor é difícil marcar uma distância entre essas duas correntes, o culto ao silvestre e o evangelho da ecoeficiência, na medida em que a WWF em parceria com a Shell ${ }^{15}$, duas representantes de peso, promovem o plantio de eucalipto em várias partes do globo com a justificativa de proteção dos bosques naturais e para o aumento da absorção do carbono.

Doze anos após a publicação do livro "The Environmentalism of the Poor" traduzido para o Brasil como "O ecologismo dos pobres", Anguelovski e Martínez-Alier (2014) reconhecem que houve mudanças e aproximações das duas correntes acima descritas que os autores consideram importantes na organização de suas práticas discursivas e instrumentais,

\footnotetext{
${ }^{14}$ Acselrad, Mello e Bezerra (2009) designam o termo modernização ecológica nos seguintes parâmetros: “[...] série de estratégias de cunho neoliberal para o enfretamento do impasse ecológico sem considerar sua articulação com a questão da desigualdade social. A estratégia da modernização ecológica é aquela que propõe conciliar o crescimento econômico com a resolução dos problemas ambientais, dando ênfase à adaptação tecnológica, à celebração da economia de mercado, à crença na colaboração e no consenso"(pg. 14).

${ }^{15}$ A Shell é uma empresa multinacional petrolífera, anglo-holandesa, que refina petróleo e extrai gás. Atua na Europa, África, Américas, Oriente Médio, Ásia e Pacífico. Site: http://www.shell.com/.
} 
nas suas formas e conteúdos, e que marcam um distanciamento maior do ecologismo dos pobres. O ambientalismo do "culto ao silvestre" e sua crítica à desconexão do homem com a natureza, hoje tem sido cada vez mais atraído para uma linguagem econômica e situa a falta dessa valoração econômica a causa principal da degradação ambiental.

Assim, a natureza é vista como um ecossistema que cumpre funções na prestação de serviços para os humanos e tornou-se um 'capital natural'. Nesse contexto, é necessária a criação de um mercado que dê valores monetários a esses serviços, afinal eles não têm valores de mercado, mas é possível dar a eles valores econômicos fictícios/virtuais/nocionais. Instituições e entidades tais como a The Economics of Ecosystems and Biodiversity (TEEB), WWF e a IUCN enfatizam a relevância de atribuir valores monetários aos serviços ecossistêmicos a fim de que os tomadores de decisões e empresas foquem suas atenções sobre a conservação da biodiversidade.

Por outro lado, o "Evangelho da ecoeficiência" tornou-se a corrente mais poderosa atualmente. Seu interesse está focado sobre o conjunto da economia como um sistema, sendo melhor refletida na teoria da modernização ecológica e no amplo uso dos recursos naturais. A junção das racionalidades ecológicas e econômicas tem a função de aproximar conservacionistas e economistas na mesma arena para justificar os atuais programas de conservação global (ANGUELOVSKI e MARTÍNEZ-ALIER, 2014).

O tripé sustentabilidade, preservação ambiental e crescimento econômico estão em sintonia com o conjunto de instrumentos e receitas sobre as tecnologias sustentáveis e as políticas econômicas ambientais. Nesse rol, entram o repertório de ações já conhecidas tais como: ecoimpostos, negociações de quotas de pescas e mercados de licenças de poluição; taxas ótimas de extração de recursos; substituição de capital manufaturado por perdas de 'capital natural'; desmaterialização da economia e curvas ambientais de Kuznets; mercado de carbono e de restauração; conservação e/ou enriquecimento de áreas/ecossistemas/habitats; cidades e crescimento inteligentes; crescimento da economia verde, resumindo, desenvolvimento sustentável (ANGUELOVSKI e MARTÍNEZ-ALIER, 2014).

Não há sequer uma leve lembrança sobre um dos principais problemas dos sistemas produtivos atuais, ou seja, a toxicidade dos materiais que os alimentam e a carência de áreas para o despejo de seus resíduos, como enfatizou Martínez-Alier (2007). A simbiose entre os princípios da ecoeficiência e a alusão ao silvestre, dá a esses atores da economia ambiental do mercado de serviços ecossistêmicos o carimbo de "eficiência, efetividade e defensabilidade" para o destino e uso dos recursos naturais, ao mesmo tempo que garantem ganhos econômicos para as pessoas e o ambiente (ANGUELOVSKI e MARTÍNEZ-ALIER, 2014). 
Por outro lado, os autores ressaltam que houve uma explosão dos processos de resistência nos territórios rurais habitados por comunidades indígenas, camponesas e agricultores pobres e dentro das comunidades urbanas fragilizadas, ao redor do mundo, configurando um movimento por justiça ambiental global. Isso ocorreu, principalmente, a partir da década dos 1990, em função do deslocamento dos impactos ambientais do Norte para o Sul. Além disso, reconhecem também que a América Latina em particular tem uma longa história de lutas por justiça ambiental relacionadas à extração de minérios e petróleo, apropriação de terras e água, demonstrando a existência histórica das desigualdades ambientais nesse espaço. Por outro lado, ressaltam que apesar desse crescente e visível movimento, ainda não há uma organização global que congregue a diversidade de suas demandas. Assim afirmam:

Indeed, as Escobar and others have argued, environmental conflicts are not merely environmental, as activists seem to use their contestation as to address broader questions related to place, its identity, and their identity (ESCOBAR, 2008). Both in urban and in rural struggles, environmental issues are central to sustainable livelihoods. However, the reaffirmation of identity is by itself a crucial concern reinforced by environmental discourses (ANGUELOVSKI e MARTÍNEZ-ALIER, 2014, pg. 168).

Concluem os autores que disso resulta, ao longo do tempo, que a água, o ar, plantas e animais são transformados em mercadorias, tais como o foram historicamente os recursos minerais, petróleo, gás e madeira - em mercados fictícios e reais através de um sistema de compra e venda como sempre o foram. A novidade desses instrumentos é que agora as comunidades locais e os gestores de recursos recebem pagamento para preservar os recursos do seu entorno, o quê sempre o fizeram. No entanto, tais mecanismos têm sido crescentemente criticados pela centralidade da lógica de mercado no trato das questões ambientais. Para Anguelovski e Martínez-Alier (2014) são políticas e valores capitalistas que permeiam e controlam ao mesmo tempo a prática conservacionista. $\mathrm{O}$ que há entre essas duas correntes atualmente é uma nebulosa, identidades fluídas, aproximaram-se tanto que não há como identificá-las separadamente.

\subsection{O ECOLOGISMO DOS POBRES}

A terceira corrente intitulada de ecologismo dos pobres, ecologismo popular ou movimento de justiça ambiental, diferentemente das outras duas correntes, preocupa-se com os humanos pobres dos dias atuais. É a sobrevivência e a subsistência que dá materialidade e forma a essa corrente que primeiro nasce como movimento para depois tornar-se objeto da 
ciência. Assim, organizações e articulações internacionais de camponeses, ativistas, lutadores sociais e cientistas agrupam-se em organizações não governamentais globais como a Genetic Resources Action International (Grain ${ }^{16}$ ), Action Group on Erosion, Technology and Concentration (ETC Group ${ }^{17}$ ) e a Via Campesina ${ }^{18}$ para expressarem a resistência ao aumento crescente dos conflitos ecológicos distributivos no mundo (MARTÍNEZ-ALIER, 2007).

Segundo Martínez-Alier (2012), as causas principais que estão na origem desses conflitos ecológicos distributivos são os fluxos de energia e material gerados pela economia mundial em níveis jamais vivenciados anteriormente nas suas diversas cadeias produtivas - na indústria, na agricultura moderna e no setor de serviços - no decorrer dos processos de produção, compreendendo desde a extração da matéria prima ao descarte dos resíduos daí provenientes, bem como de seu consumo.

The fundamental clash between economy and the environment comes from two facts. First, population growth...Second, the social metabolism of industrial economies. Energy cannot be recycled...Similarly, materials are recycled only in part, and therefore, even an economy that would not grow, would need fresh supplies of iron ore, bauxite, copper. The growth in the number of resource extraction conflicts and also waste disposal conflicts is explained by the social metabolism (MARTÍNEZ-ALIER, 2014, pg. 240).

Segundo Martínez-Alier et al. (2010) o sociólogo Stephen Bunker e o antropólogo e historiador Alf Hornborg, ambos especialistas na Amazônia brasileira, são considerados os pioneiros nos estudos sobre o metabolismo social e as trocas ecológicas desiguais. Ao longo dos últimos vinte anos, esse debate surge com força na América Latina e é ele que dá base aos estudos posteriores sobre os conflitos ecológicos distributivos. Com uma ampla agenda de pesquisa, reunindo especialistas de uma variedade de campos disciplinares - economia ecológica, ecologia social, geografia econômica e ecologia política - deu visibilidade a uma variedade de dinâmicas sociais e conflitos ambientais por meio de estudos de casos em diversas partes do mundo.

Nesse texto, datado de 2010, Martínez-Alier et al., sintetiza as premissas que dão base a esses estudos. Em primeiro lugar, os autores demarcam a filiação teórica com que esse campo de estudos dialoga, a saber, a teoria do sistema mundo ${ }^{19}$. Nesse sentido, entendem que

\footnotetext{
${ }^{16}$ Site: https://www.grain.org/.

${ }^{17}$ Site: http://www.etcgroup.org/content/rafi-becomes-etc-group.

${ }^{18}$ A Via Campesina foi criada em 1993, reunindo camponeses e camponesas, pequenos e médios agricultores, indígenas, trabalhadores e trabalhadoras rurais sem terra, migrantes e trabalhadores agrícolas. Atualmente reúne 164 organizações locais e nacionais, em mais de 73 países da África, Ásia, América e Europa e lutam por um novo paradigma denominado, Soberania Alimentar. De acordo com Caldart et al. (2012), no verbete Via Campesina essa é uma organização mundial que articula movimentos camponeses em defesa e construção da soberania alimentar(FERNANDES, 2012). Site: http://viacampesina.org/en/.

${ }^{19}$ A teoria do Sistema Mundo foi criada por Immanuel Maurice Wallerstein, sociólogo estadunidense, e segundo
} 
a pilhagem do planeta está diretamente relacionada com o crescimento econômico; a busca por lucro; os altos índices de consumo; pelo crescimento populacional e pelas tecnologias atuais demandadoras de insumos e produtoras de lixo.

Por outro lado, segundo esses autores, a situação tende a agravar-se, na medida em que esse sistema opera sem considerar que os recursos do planeta são finitos; que há desigualdades na distribuição dos benefícios e de seus custos; que como creem alguns, a modernização ecológica não alcançou a 'desmaterialização' da economia e sendo uma das principais características dos processos produtivos atuais, a abertura, o que entra como insumo, sai do sistema como lixo; deduz-se que há espaços suficientes no universo para armazená-lo. Esses são os motivos, especialmente, pelo acúmulo de dejetos, materiais descartáveis e lixos tóxicos que Martínez-Alier (2007) faz a seguinte consideração: “Talvez, o problema mais grave para a sustentabilidade seja a disponibilidade ou a toxicidade dos materiais e a carência de áreas para despejo dos resíduos, bem mais do que a escassez de recursos" (pg. 73-74). Embora, em diversas ocasiões, Martínez-Alier (2007, 2010, 2012, 2014) reafirme que:

The roots of the conflicts lie not only in failures of governance and in maladapted institutions, or in inadequate pricing but in the appetite of the world economy for inputs ${ }^{20}$ coming from the commodity frontiers, and the resulting export of waste from the metropolitan centres (MARTÍNEZ-ALIER ET AL., 2010).

De acordo com Martínez-Alier (2007) a economia ecológica e a ecologia política deram a base sobre a qual o movimento do ecologismo dos pobres ou a justiça ambiental deslanchou como um campo científico de estudo. A primeira disciplina é caracterizada como transdisciplinar, cuja principal preocupação gira em torno dos impactos ambientais provocados pelo sistema da economia atual, visando entre outros objetivos, corrigir a contabilidade macroeconômica baseada apenas em cálculos monetários e desconsiderando os requerimentos materiais e energéticos (físicos) desse sistema. Além disso, essa disciplina se debruça sobre a gestão dos direitos de propriedade e dos recursos naturais, combinando economia e meio ambiente, por meio de ferramentas de modelagens, produzindo o que se

Santos (2000), analisa “[...] a formação e evolução do modo capitalista de produção como um sistema de relações econômico-sociais, políticas e culturais que nasce no fim da Idade Média europeia e evolui para se tornar um sistema planetário e confundir-se com a economia mundial. Esse enfoque, ainda em elaboração, destaca a existência de um centro, uma periferia e uma semiperiferia, além de distinguir, entre as economias centrais, uma economia hegemônica que articula o conjunto do sistema [...] a evolução do capitalismo é considerada uma sucessão de ciclos econômicos, articulados com processos políticos, sociais e culturais" (pg. $57)$.

${ }^{20}$ Leia-se petróleo: minas para retirada de diversos tipos de recursos; barragens para geração de energia e outros fins; material para a construção civil; terras para ampliação de produtos substitutos dos combustíveis fósseis e outros materiais, tais como biomassa e plantações de monocultivos de pinus e eucaliptos, entre outros. 
convencionou chamar avaliação multicriterial. Esse tipo de avaliação tem alimentado novos formatos no que toca ao desenho, monitoramento e avaliação na tomada de decisão sobre política ambiental. Nessa abordagem, essa disciplina contribui com o avanço nos estudos sobre Justiça Ambiental.

A economia ecológica não se compromete com um tipo de valor único. Ela abarca a valorização monetária, mas também avaliações físicas e sociais das contribuições da natureza e os impactos ambientais da economia humana mensurados nos seus próprios sistemas de contabilidade. Os economistas ecológicos 'levam em consideração a natureza', nem tanto em termos crematísticos ${ }^{21}$, quanto por intermédio de indicadores físicos e sociais (MARTÍNEZ-ALIER, 2007, pg. 53).

Nenhuma disciplina consegue abarcar a complexidade dos sistemas criados pela humanidade em sua relação com a natureza. Disso decorre a produção do conhecimento científico em uma centena de recortes disciplinares e por vezes pela conjunção de diálogos entre as diferentes disciplinas na tentativa de compreender/apreender as realidades. Nesse sentido, a ecologia política debruça-se sobre as relações de poder produzidas no seio das relações do homem com a natureza, e dos homens entre si, derivando estudos sobre a distribuição desigual dos recursos socioambientais, incluindo as desigualdades de renda, de acesso aos recursos naturais ou serviços ambientais, e principalmente os conflitos decorrentes desse processo. Assim conceitua Martínez-Alier:

A ecologia política estuda os conflitos ecológicos distributivos. Por distribuição ecológica são entendidos os padrões sociais, espaciais e temporais de acesso aos benefícios obtidos dos recursos naturais e aos serviços proporcionados pelo ambiente como um sistema de suporte da vida. Os determinantes da distribuição ecológica são em alguns casos naturais, como o clima, topografia, padrões pluviométricos, jazidas de minerais e qualidade do solo. No entanto, também são claramente sociais, culturais, econômicos, políticos e tecnológicos (MARTÍNEZALIER, 2007, pg. 113).

Esse novo campo da produção do conhecimento nasce dos estudos de caso provenientes da geografia e da antropologia rural e vem sendo estudados por sociólogos ambientais também (Martínez-Alier, 2007, 2012; Martínez-Alier et al., 2010). A abordagem do Ecologismo dos Pobres se situa no âmbito dos estudos da Ecologia Política, especificamente, nos estudos dos conflitos ecológicos distributivos. Assim declara MartínezAlier (2007): “A desigual incidência de danos ambientais ante não só as demais espécies ou as futuras gerações de humanos, mas em nossa própria época, justifica o nascimento do ecologismo popular ou do ecologismo dos pobres" (pg. 89).

\footnotetext{
${ }^{21}$ De acordo com Martínez-Alier (2007), crematística corresponde ao “[...] estudo da formação dos preços de mercado, para ganhar dinheiro" enquanto que 'oikonomia' seria a reprodução material da casa familiar.
} 
O campo da Ecologia Política não dever ser dividido em conflitos sobre indústrias extrativas, conflitos sobre o uso da água e uso da terra, sobre poluição do ar ou dejetos sólidos e, finalmente mudanças climáticas ou conflitos de desastres naturais, mas deve manter uma perspectiva sistemática integrando métodos para o estudo do metabolismo social com métodos para a análise política e sociológica (MARTÍNEZ-ALIER, 2010).

O ecologismo dos pobres tornou público várias das práticas de empresas e de Estados nacionais geradoras de conflitos socioambientais. Um dos exemplos é o que diz respeito ao que ficou conhecido como Biopirataria internacional. Tal prática, com vários exemplos de casos de apropriação indevida, não apenas do assalto a matéria-prima da biodiversidade diretamente dos locais de origem, como também, do acesso ao conhecimento a ela associado, gerando casos emblemáticos de recursos a tribunais e que serviu de base para diversos artigos consolidados na Convenção do Rio, de 1992, e para o surgimento dos contratos de "bioprospecção", cujo caso referência é representado pelo acordo InBio-Merck da Costa Rica (MARTÍNEZ-ALIER, 2007).

Por outro lado, o fortalecimento dos regimes de propriedade intelectual, representado pela proliferação de patentes, em especial ligado às variedades de cultivos e ao conhecimento camponês, até então considerado bens públicos, e não uma mercadoria, ameaça milhares de camponeses, comunidades tradicionais e populações indígenas que têm a agricultura como base de sustentação da vida, e a soberania alimentar dos povos do Sul global.

O ecologismo dos pobres deu visibilidade a outros tipos de valoração e interesses, que não exclusivamente as de base monetárias ou econômicas, sobretudo, aqueles valores relacionados às formas de sustento e de modos de vida e sobrevivência, a soberania alimentar; aos direitos humanos e direitos territoriais comunitários e aos direitos relacionados ao patrimônio cultural de um povo, como seus lugares sagrados. Esses tipos de valoração entram em disputa nos conflitos socioambientais, não apenas, pelo acesso a recursos naturais e serviços ambientais necessários a sobrevivência de homens e mulheres que compartilham contextos sociais em processos crescentes e intensos de empobrecimento material, mas também por direitos territoriais secularmente adquiridos. Muitos desses conflitos estão inseridos em territórios de comunidades tradicionais, povos indígenas, camponeses, agricultores familiares, notadamente, populações fragilizadas por suas condições de pobreza econômica contra a ação de grupos econômicos e estados nacionais ávidos pela usurpação das fronteiras de recursos considerados commodities (petróleo, gás, minérios, construção de represas para geração de energia, etc.), como também pela busca de repositórios para o 
despejo e descarte do lixo produzido pelo mecanismo social dos processos produtivos atuais, seja na indústria, na agricultura ou no setor de serviços.

Por outro lado, o ecologismo dos pobres também se debruça sobre as narrativas das resistências que vem sendo construídas pelos diferentes movimentos da justiça ambiental e que constitui um verdadeiro laboratório de produção de ecologia de saberes reivindicado por Santos e Meneses ${ }^{22}$ (2010) no livro Epistemologias do Sul. Um dos melhores exemplos utilizados por esses autores para fazer referência a essa diversidade é a preservação da biodiversidade, a qual acrescentaria, da agrobiodiversidade ${ }^{23}$ realizada pelas comunidades tradicionais, os povos indígenas, camponeses e agricultores familiares.

[...] há um crescente alarme nos países do Sul que abrigam centros de biodiversidade agrícola e nos países vizinhos devido à desaparição da agricultura tradicional. Essa nova consciência, totalmente contrária às errôneas doutrinas vigentes quanto ao desenvolvimento econômico, está apoiada na distância social e cultural existente entre as companhias de sementes (geralmente multinacionais, como a Monsanto) e os camponeses locais. Os discursos da exploração social e da soberania alimentar têm sido somados aos da defesa da biodiversidade agrícola contra a erosão genética. Enquanto a conservação da biodiversidade "selvagem" em "parques nacionais" é frequentemente entendida como uma ideia do Norte (...) a conservação da biodiversidade agrícola in situ foi deixada de lado por muitos anos pelas grandes organizações conservacionistas dos países do Norte. Esse entendimento foi alterado por ONGs específicas como Rafi e Grain, além de cientistas e grupos do Sul que desenvolveram uma ideologia pró-camponeses (MARTÍNEZ-ALIER, 2007, pg. 200).

Essa mobilização crescente das comunidades, povos e organizações relacionados aos conflitos ecológicos distributivos são frutos do avanço do capitalismo em busca de novas fronteiras de recursos naturais, do aumento das contaminações químicas da água, do solo e do ar; do desmatamento, desertificação e degradação dos solos; e consequentemente, dos crescentes riscos característicos dos dias atuais e que impactam diferentemente as pessoas e os lugares. Certamente, os mais pobres carregam a carga mais pesada, intensa e que vem se prolongando no tempo e nos espaços, na medida em que não tem condições estruturais, financeiras e de poder para mudar as relações de poder impostas por essa lógica do metabolismo social e interesses privados. Portanto, os conflitos ecológicos distributivos caracterizam-se por serem geograficamente e socialmente desiguais.

\footnotetext{
${ }^{22}$ Para Sousa e Meneses (2010) a ecologia de saberes reflete o acúmulo de conhecimento produzido pelas camadas subalternas do Sul global e expressam "[...] diversas formas de conhecimento da matéria, sociedade, vida e espírito, como também muitos e diversos conceitos sobre o que conta como conhecimento e os critérios que podem ser usados para validá-los" (pg. 54).

${ }^{23} \mathrm{O}$ conceito de agrobiodiversidade é recente, datado segundo Santilli (2009) dos últimos 10 a 15 anos, em um contexto interdisciplinar, resultado "[...] da intervenção do homem sobre os ecossistemas: de sua inventividade e criatividade na interação com o ambiente natural” (SANTILLI, 2009, pg. 94).
} 
Outra tese defendida por Martínez-Alier (2014b) diz respeito ao conjunto de atores sociais historicamente excluídos que hoje compõem o mosaico de movimentos pela Justiça Ambiental e pelo Ecologismo dos pobres, fortemente centrados na parcela pobre das populações, no campo e na cidade. Isso não significa dizer que todos os ambientalistas são pobres e que todos os pobres são ambientalistas. Esclarece o autor:

[...] the 'environmentalism of the poor' does not assert that as a rule poor people feel, think and behave as environmentalists. This is not so. The thesis is that in history and today, the poor are often on the side of the preservation of nature against business firms and the state. This behaviour is consistente with their interests and with their values (MARTÍNEZ-ALIER, 2014b, pg. 240).

Os estudos têm mostrado avanços significativos no processo de conscientização e visibilidade na construção de alternativas e formas de resistências protagonizadas pelo movimento da Justiça Ambiental com ganhos reais para essas populações atingidas por esses conflitos, em especial os pobres do Sul global. Desse modo, Martínez-Alier (2007) afirma:

Temas do ambientalismo global, como a conservação da biodiversidade, as ameaças dos praguicidas e a economia de energia, são transformados em argumentos com inserção local, legitimando a melhoria das condições de vida e a sobrevivência cultural dos camponeses, os quais estão aprendendo a não se ver mais como condenados ao desaparecimento. Essa argumentação está se difundindo amplamente no decurso de novas redes, como a formada pela Via Campesina (pg. 205).

Nesses contextos, o conceito de 'Justiça Ambiental' é muito importante, não somente porque ele diz respeito aos custos e benefícios dos danos causados por esses conflitos, mas, sobretudo, porque discute reivindicações e direitos de reconhecimento e participação, trabalhando assim, na perspectiva de conceitos caros aos pobres como democracia e existência (outras formas de ver e estar no mundo). Nesses conflitos, os protagonistas não são os sindicatos de trabalhadores ou as sociedades de conservação; são as organizações de justiça ambiental, grupos indígenas e camponeses, cidadãos e mulheres ativistas.

\subsection{O MANTRA DA JUSTIÇA AMBIENTAL}

A Justiça Ambiental é considerada por Martínez-Alier (2007) mais próxima da sociologia ambiental e dos estudos das relações étnicas do que com a ética ambiental ou a filosofia. No entanto, atualmente este campo tem ampliado o seu horizonte conforme veremos no decorrer dessa leitura.

O Ecologismo dos pobres, declara Martínez-Alier (2007, 2012, 2014a, 2014b), é um tipo de movimento dentro dessa corrente que nasce como um movimento e hoje se consolida como um campo de pesquisa e produção acadêmica com grupos de pesquisadores e ativistas 
em várias partes do mundo. Nascido no início dos anos de 1980, nos Estados Unidos ${ }^{24}$, com a denominação de racismo ambiental, devido à instalação de depósitos de lixos em locais de moradia de comunidades negras e latino-americanas empobrecidas, mais tarde atravessa as fronteiras e ganha articulação internacional por meio do movimento da Justiça Ambiental (MARTÍNEZ-ALIER, 2007; MOHAI et al., 2009). Conforme assinalam Acselrad, Mello e Bezerra (2009) esse movimento, pela primeira vez na história do debate ambiental, articulou as lutas de caráter social, territorial, ambiental e de direitos civis. Como descreve MartínezAlier (2007):

[...] este movimento inventou uma potente combinação de palavras, 'justiça ambiental' [...] desviando no cenário americano o debate ecológico da preservação e conservação da natureza para a justiça social, desmantelando a imagem dos protestos ambientais do tipo 'não no meu quintal' (ou seja NIMBY ${ }^{25}$ ), convertendoos para lutas do tipo 'em nenhum quintal' (isto é, NIABY), ampliando o círculo de pessoas implicadas na política ambiental (pg. 235).

Tais lutas, cotidianas, enfrentadas pelas minorias negras e pobres dos Estados Unidos, assemelham-se as centenas de lutas da maioria dos povos indígenas, comunidades tradicionais e camponesas, empobrecidas, ao redor do globo, que lutam pela manutenção de seus territórios, por suas formas de vida e sobrevivência (MARTÍNEZ-ALIER, 2007).

Segundo Temper et al. (2015) o primeiro acadêmico a teorizar o fato foi Robert Bullard (1990), um sociólogo, discutindo sobre a distribuição desigual dos custos ambientais e sociais entre os grupos sociais distinguindo raça/etnia, classe social, gênero, idade e distinção espacial. Foi estabelecido a partir daí relações entre poluição, raça e pobreza. Os primeiros estudos enquadravam-se como pertencente ao campo da sociologia ambiental. A ciência deslocaria suas atenções em torno dessa corrente apenas nos anos de 1990, uma década depois de seu surgimento nos Estados Unidos.

A partir da geografia e da antropologia, cresce o campo da Ecologia Política ampliando e expandindo para questões multidimensionais e interligando questões da justiça como distribuição, reconhecimento e participação. O movimento influencia a criação de outros similares em diversas partes do globo, inclusive no Brasil. E na América Latina,

\footnotetext{
${ }^{24}$ Segundo Acselrad, Mello e Bezerra (2009) e Martínez-Alier (2007) a experiência que ganhou maior visibilidade e força, elevando a 'justiça ambiental' ao encontro da luta pelos direitos civis, ocorreu em Afton, no condado de Warren, na Carolina do Norte, em 1982. A palavra 'racismo ambiental' foi cunhada pelo reverendo Benjamin Chavis e a organização da comunidade sob a coordenação da Comissão de Justiça Racial da United Church of Christ que solicitou a pesquisa desenvolvida por Robert D. Bullard, marcando o início dos estudos dos conflitos ecológicos distributivos.

${ }^{25}$ NIMBY - sigla em inglês para a expressão "Not in my backyard" e NIABY "Not in anybody's backyard" (MARTÍNEZ-ALIER, 2007).
} 
origina-se o debate em torno da noção de "Dívida Ecológica dos países do Norte para os do Sul, 26 .

Assim como as demais correntes, a ciência aporta conhecimentos para o fortalecimento desse campo, expandindo para diferentes contribuições em disciplinas como agroecologia, etnoecologia, ecologia política, ecologia urbana e economia ecológica. Há um diferencial no campo da Justiça Ambiental no que se refere à construção do conhecimento em que ativistas e cientistas utilizam uma variedade de estratégias para a produção conjunta desse conhecimento. Uma de suas principais características é o uso da denominada ciência engajada, de construção de práticas de conhecimentos, baseada na pesquisa-ação e na participação dos atores diretamente envolvidos nos conflitos. Martínez-Alier utiliza como exemplo a institucionalização da área da epidemiologia popular como um exemplo clássico do modus operandi desse campo:

A 'epidemiologia popular' constitui um rol de iniciativas nas quais a população coleta os dados científicos e demais informações de interesse e, além disso, faz levantamentos dos resultados fornecidos pelos especialistas oficiais, para posteriormente desafiá-los em petições judiciais relacionadas com a contaminação tóxica. Trata-se de casos de avaliação levados adiante por 'não especialistas' (pg. 239).

Por esse motivo, em grande medida, os conceitos (significados e materialidade) provêm das narrativas dos sujeitos que vivenciam tais conflitos, reivindicam e constroem a Justiça Ambiental. Conceitos como justiça ambiental, epidemiologia popular, ecologismo dos pobres, ecologismo operário, equidade geográfica, justiça do clima, biopirataria, justiça pela água, entre outros compõem esse léxico constituído por esse que é considerado ao mesmo tempo um movimento social e um objeto de pesquisa, o que traz implicações na forma de produzir conhecimentos e no modo de conceber o processo da ciência (MARTÍNEZ-ALIER et al., 2014c). Assim, confirmam Acselrad, Mello e Bezerra (2009): “[...] o Movimento de Justiça Ambiental estruturou suas estratégias de resistência recorrendo de forma inovadora à produção própria de conhecimento"(pg. 19).

Segundo esses autores, já em 1987, as organizações desses movimentos, incluindo os movimentos sociais tradicionais e pesquisadores reuniam-se para construir instrumentos para uma 'avaliação de equidade ambiental', considerando variáveis sociais nos estudos de impactos ambientais. Esse reconhecimento dos saberes das pessoas, dos grupos e suas organizações sobre seus espaços de vida torna a formulação das políticas ambientais mais

\footnotetext{
${ }^{26}$ De acordo com Martínez-Alier (2007) é a dívida acumulada pelos países do Norte pelo uso dos recursos ecológicos (produtos e serviços ecossistêmicos) e sociais dos países do Sul nas suas trocas comerciais. Como é um conceito em construção envolve um amplo debate sobre a sua composição e operacionalização.
} 
inclusivas e menos discriminatórias. Mais tarde essas proposições transformaram-se nas atuais avaliações multivalorativas ${ }^{27}$ (multicritérios - EMC).

Nesse sentido, o projeto intitulado EJOLT $^{28}$, que reúne a sociedade civil e pesquisadores para catalogar e analisar a distribuição dos conflitos ecológicos distributivos no âmbito global, com redes similares no mundo, corresponde a essa perspectiva de uma nova forma de construir conhecimento. Um dos principais produtos desse projeto é o Atlas Global da Justiça Ambiental ${ }^{29}$ (EJAtlas). Por meio da análise do fluxo de material e energia com a abordagem de cadeia produtiva da Ecologia Política, o atlas mapeia os conflitos ecológicos e os espaços de resistência em uma base de dados online e interativo (TEMPER, DEL BENE e MARTÍNEZ-ALIER, 2015). Outros mapas foram construídos no mesmo sentido com abrangência mais temática como no caso do Brasil, elaborado pela FIOCRUZ e Fase ${ }^{30}$ mapeando Justiça Ambiental e saúde no Brasil e o Observatório de Conflitos da Mineração na América Latina ${ }^{31}$.

Todos esses instrumentos colaboram na divulgação e criação de uma consciência dos problemas ambientais, pois dão visibilidade a problemas que antes estavam restritos as comunidades afetadas, aos movimentos por Justiça Ambiental e aos cientistas que se debruçam sobre esses temas. Como afirma Temper, Del Bene e Martínez-Alier (2015): "These new politics aim to establish recognition and authority through witnessing, peer validation and transparency of data sources rather than through academic peer-review" (pg. 263).

E mais que isso, reforça a principal tese do movimento por Justiça Ambiental que desde o princípio buscam demonstrar que:

[...] sobre os mais pobres e os grupos étnicos desprovidos de poder recai, desproporcionalmente, a maior parte dos riscos ambientais socialmente induzidos, seja no processo de extração dos recursos naturais, seja na disposição de resíduos no ambiente (ACSELRAD, MELLO e BEZERRA, 2009, pg. 12).

Isso porque, segundo esses autores, essa questão foi tradicionalmente relegada pelo movimento ambientalista tradicional, cuja centralidade do debate se deu em torno de temas

\footnotetext{
${ }^{27}$ Expressão utilizada por Martínez-Alier (2007).

${ }^{28}$ Environment Justice Organizations, Liabilities and Trade (EJOLT) - É um projeto de pesquisa, envolvendo a ciência e a sociedade, objetivando catalogar e analisar os conflitos ecológicos distributivos ao redor do mundo e enfrentar as injustiças ambientais. Site: http://www.ejolt.org.

${ }^{29}$ Acesso no site: https://ejatlas.org/. Desde seu lançamento até agosto de 2015, o EJAtlas registrou mais de 1500 casos de conflitos, com maior concentração nos casos da indústria de extração (petróleo e gás, mineração e desmatamento, entre outros); aquisição de terras, manejo da água e depósitos de lixo (incineradores e aterros) (TEMPER, DEL BENE e MARTÍNEZ-ALIER, 2015).

${ }^{30}$ FIOCRUZ/FASE - Site: http://www.conflitoambiental.icict.fiocruz.br/index.php.

${ }^{31}$ Observatório de Conflitos da Mineração na América Latina. Site: http://www.conflictosmineros.net/.
} 
como a dilapidação e a finitude dos recursos naturais. Acselrad, Mello e Bezerra (2009), elencam os quatro princípios que congrega a diversidade de organizações que compõem atualmente o movimento de justiça ambiental, são eles:

i) Solidariedade, transformada num princípio-lema, 'poluição tóxica para ninguém';

ii) Lutar por um outro modelo de desenvolvimento;

iii) Justiça nos processos de transição para uma nova relação da sociedade com a natureza;

iv) Democracia, entendida como participação permanente dos interessados na formulação da política ambiental.

Para tanto, foram desenhadas estratégias que vêm sendo operacionalizadas pelos diversos atores, em diferentes campos de atuação, alcançando visibilidade por meio de uma diversidade de ações que engloba desde o exercício da pressão política direta a programas internacionais de pesquisa, quanto à globalização do movimento em várias áreas e setores. Esse movimento vem acompanhado de conquistas históricas nesse campo por vezes revertendo casos de injustiças ambientais.

As lutas por justiça ambiental constituem, assim, uma potente forma de resistência organizada contra os efeitos perversos da mobilidade espacial do capital e dos esforços que os grandes interesses econômicos empreendem para instaurar diferentes padrões socioambientais para suas atividades - normas mais rigorosas em países e áreas ricas, normas mais frouxas em países e áreas pobres (ACSELRAD, MELLO e BEZERRA, 2009, pg. 36).

Isso porque cresce o entendimento de que os estados nacionais, em especial àqueles que detêm vastos territórios, como é o caso do Brasil, historicamente, produzem políticas e ações que privilegiam empresas, latifúndios e os mais ricos, em detrimento de suas populações pobres, confirmando a visão de Martínez-Alier (2007) que o Estado tem se transformado ao longo da história um dos principais atores antiambientais. Por outro lado, o crescimento da ação das organizações ambientalistas transnacionais que atuam para influenciar a governabilidade ambiental internacional tem colaborado para o fortalecimento da participação da sociedade civil nas arenas internacionais, mesmo que seja na construção dos eventos paralelos que acontecem concomitantes com as cúpulas e conferências das instituições da governabilidade internacional. Ainda que, como salienta Martínez-Alier (2007) nem sempre essas grandes redes ambientais internacionais, como Greenpeace, IUCN, Network, entre outras, posicionem-se na mesma direção das organizações de bases do Sul. O que há de novidade nos últimos anos é a ação da Via Campesina que propõe uma nova política agrícola mundial. Assim conclui Martínez-Alier (2007):

No geral, o movimento que temos denominado de culto à vida selvagem depende do Estado em quase todas as partes do mundo para a demarcação dos parques naturais, 
vez por outra em oposição aos desejos das populações locais. Ao mesmo tempo, os ambientalistas populares atuam contra o Estado nas questões relacionadas com a extração de petróleo, mineração e construção de barragens, sem contar que também operam fora da esfera estatal nos movimentos agroecológicos camponeses (pg. 274).

Nesse sentido, mesmo nos países democráticos, a disputa entre a afirmação dos direitos pela justiça ambiental ainda tem um longo caminho a ser percorrido, mesmo naqueles que tenham governos 'comprometidos' com a justiça social. Movik (2014) estudando sobre a reformulação da política para a distribuição dos recursos hídricos na África do Sul, denominada de Water Allocation Reform, iniciada em 2003, chama a atenção sobre a frágil problematização em torno dessas questões conceituais no campo da produção e formulação de políticas públicas, no âmbito do acesso aos recursos ambientais, na medida em que a centralidade dos trabalhos acadêmicos da Justiça Ambiental tem recaído sobre as manifestações físicas das injustiças ambientais. E nesse universo, a linguagem dos direitos, em especial, dos direitos humanos - o direito a um ambiente saudável, por exemplo - tem sido mais fortemente evocada.

Esse autor levanta um questionamento sobre a pretensa existência de uma universalidade e unidade do direito em questões de justiça ambiental, reivindicado por alguns atores, desconsiderando o contexto socioambiental onde é produzido. O termo justiça, por seu caráter complexo, envolve interesses e preocupações, mas também noções como mérito, utilidade e igualdade, que dificultam sua construção conceitual abstrata, distante da realidade. Esse processo de concepção e desenho de noções que dão substancialidade aos processos de construção de equidade e justiça ambiental não podem ser desenraizados da história dos lugares. Isso porque, de acordo com o autor, os negros pobres sul-africanos, muito antes da institucionalização do regime do Apartheid, na África do Sul, vivenciaram uma das mais incompreensíveis estruturas de desigualdade socioambiental e racial, com relação ao processo distributivo de acesso aos recursos ambientais.

The first explicitly racista policies that were the precursors to the apartheid regime were enacted in the early twentieth century. The most notorious example was the 1913 Land Act, which reserved 87\% of the country's land for white people...The discrimination and inequity characterising access to land was also reflected in the distribution of water resources. The 1956 Water Act was founded on the doctrine of riparianism, which implied that only those individuals owning land adjacente to the river were entitled to 'reasonable use' of water. Most of the riparian landowners were White farmers, who enjoyed generous government subsidies... (MOVIK, 2014, pg. 190).

Como ele observou no debate sobre a reformulação da política de acesso a água na África do Sul, cujo confronto se deu entre os dois principais tipos de usuários, o Existing 
Lawful Uses (ELUs), categoria concebida na base da noção de direito adquirido, e o Historically Disadvantaged Individuals ${ }^{32}$ (HDIs), categoria que reconhece o histórico das desigualdades de acesso aos recursos ambientais dos sul-africanos negros e pobres entraram em confronto, demonstrando que a história dos lugares e os contextos socioeconômicos e culturais permeiam as construções atuais sobre as noções que dão base ao campo da justiça ambiental. Essa constatação confirma o que Martínez-Alier (2007) afirma: "Com toda certeza os conflitos são social e politicamente modelados e suas formas específicas requerem uma análise contextual" (pg. 109).

Para o caso do Brasil em particular, Acselrad (2010), Picolotto e Brandenburg (2015) e Santilli (2009) e outros autores relata que o marco de encontro entre meio ambiente e justiça social se deu em meados dos 1980, com a criação do Fórum Brasileiro de ONG e Movimentos Sociais para o Meio Ambiente e Desenvolvimento, por ocasião dos preparativos da Conferência da $\mathrm{ONU}^{33}$, em 1992. Nesse momento, segundo registra o autor há uma clara divisão interna no ambientalismo brasileiro, entre três principais tendências, assim delineadas:

i) Um segmento representando o pragmatismo paraestatal ou paraempresarial e a crítica ao modelo de desenvolvimento;

ii) Os defensores da busca de instrumentos da modernização ecológica do capitalismo brasileiro;

iii) E o ecologismo combativo representado pelos atores sociais investido na expansão no campo dos direitos.

No campo do ecologismo combativo, inserem-se progressivamente movimentos sociais já bem constituídos, que ambientalizam as pautas dos grupos subalternos que pretendem representar, analogamente ao que acontecera já nos 1980 com os seringueiros do Acre (ACSELRAD, 2010, pg. 106).

O autor cita especialmente o Movimento de Atingidos por Barragens (MAB) e o Movimento dos Trabalhadores Rurais Sem Terra (MST) que questionam o sistema de produção 'moderna' que além de destruir as bases do sistema de produção, tais como a fertilidade dos solos e a biodiversidade, ainda não cumpre a função social da propriedade da terra. Para Acselrad (2010) são esses atores sociais que no país relacionam a sua ação à noção de "justiça ambiental". Acrescentaria, na atualidade, o conjunto de entidades que compõem a Via Campesina ${ }^{34}$, entre elas, o Movimento de Pequenos Agricultores (MPA) que surge após

\footnotetext{
${ }^{32}$ A África do Sul viveu mais de 300 anos de colonialismo - de 1652 a 1961 - e durante este período estabeleceu o regime de segregação racial denominado Apartheid (1948-1994) (MOVIK, 2014).

${ }^{33}$ Conferência das Nações Unidas sobre o Meio Ambiente e o Desenvolvimento, realizada no Rio de Janeiro, em junho de 1992, também conhecida como Cúpula da Terra.

${ }^{34}$ Fazem parte da Via Campesina, as seguintes organizações brasileiras: MST, MAB, Movimento de Mulheres
} 
esse momento da realização da Conferência como veremos mais adiante. Assim, o movimento de justiça ambiental no Brasil caracteriza-se por aliar:

[...] a defesa dos direitos a ambientes culturalmente específicos - comunidades tradicionais situadas na fronteira da expansão das atividades capitalistas e de mercado; a defesa dos direitos a uma proteção ambiental equânime contra a segregação socioterritorial e a desigualdade ambiental promovidas pelo mercado; a defesa dos direitos de acesso equânime aos recursos ambientais, contra a concentração das terras férteis, das águas e do solo seguro nas mãos dos interesses econômicos fortes no mercado (ACSELRAD, 2010, pg. 114).

Isso porque segundo Acselrad, Mello e Bezerra (2009), há mecanismos próprios de produção das injustiças ambientais e entre esses mecanismos estão:

i) O mercado que por meio da ação de poderes econômicos e políticos gera a segregação socioespacial, conjugando divisão social e espacial da degradação ambiental em um mesmo espaço;

ii) A omissão e a adoção de políticas estatais, em especial, na localização de grandes empreendimentos que afetam populações tradicionais e indígenas, bem como o rígido controle na aplicação da legislação a determinados setores como os camponeses;

iii) Desinformação - a ausência de informações como padrão da ação de grandes empresas nacionais e multinacionais nos diversos setores representa um incentivo para a produção das injustiças;

iv) Neutralização da crítica potencial.

Há um processo intenso de silenciamento das injustiças no país por parte de quem detém o poder, seja estatal ou não, por esse motivo, construir a resistência tornou-se um imperativo para os movimentos de justiça ambiental. Nos últimos anos, assiste-se a uma proliferação de experimentações sociais em todos os âmbitos da vida societal, em especial, no campo, aonde o avanço do capital vem tomando formas sutis na apropriação dos territórios camponeses.

A Via Campesina pode ser caracterizada como um movimento socioambiental ou ambientalista que vem trabalhando no seu interior, nos diferentes lugares onde suas organizações estão inseridas, programas alternativos de desenvolvimento. Como afirma Martínez-Alier (2007):

[...] a luta nos países do Sul pela agroecologia tradicional e contra as empresas transnacionais de sementes não é - ao menos por enquanto - minoritária, sendo potencialmente relevante para centenas de milhões de famílias camponesas. A racionalidade ecológico-econômica dos sistemas camponeses proporciona um ponto de partida prático para uma modernização alternativa (pg. 280).

Camponesas (MMC), MPA, Pastoral da Juventude Rural (PJR), Movimento de Pescadores e Pescadoras Artesanais (MPP) e Coordenação Nacional das Comunidades Quilombolas (CONAQ). 
Este é o caso específico do Movimento dos Pequenos Agricultores-MPA e seu projeto de soberania alimentar no que diz respeito à construção da soberania genética. Assim, reconhece Martínez-Alier (2007): "Esses movimentos locais de resistência reforçam as redes globais e, por sua vez, se enriquecem em vários contextos ao incorporarem a linguagem e a força do ambientalismo global às suas formas locais de resistência" (pg. 344).

Ao dá visibilidade a esses processos de resistências que muitas vezes tornam-se programas alternativos de continuidade de modos de existir no mundo, como nos casos das experiências de soberania alimentar - a pesquisa possibilita desvendar padrões de conflitos socioambientais historicamente instalados. Isso porque, ao permitir observar não apenas os “impactos ambientais" físicos e/ou biológicos, alcança o conflito originário da relação do homem e da mulher com a natureza, mas, sobretudo, a relação do homem com o homem e desses com as mulheres, ou seja, os padrões das relações de poder que possibilitam a instituição das desigualdades de acesso aos recursos socioambientais.

Nessa medida, compreendo que o ecologismo dos pobres e a justiça ambiental restabelecem a partir da noção de conflito, o cerne do debate ambiental contemporâneo. Pois sem visibilizar o conflito ou os conflitos, possivelmente as causas e as raízes do problema ambiental jamais seriam explicitadas. Portanto, para recontar a narrativa da soberania alimentar a partir das experimentações do MPA, desvendar os conflitos ecológicos distribuitivos que os envolve compõem um de seus repertórios fundadores, na medida em que a luta pela soberania alimentar existe na proporção da existência desses conflitos. 


\section{SÍNTESE DO CAPÍTULO}

O presente capítulo estabeleceu as bases conceituais em que o presente trabalho se fundamenta para observar os processos que envolvem não apenas a experiência que o movimento estabeleceu, mas sobretudo compreender o contexto histórico, econômico, social e cultural em que ocorrem os principais conflitos socioambientais que compartilham os camponeses no país, expresso pelas categorias de justiça ambiental e soberania alimentar.

Como foi demonstrado, tais noções são produtos instituídos pelo próprio movimento social na sua luta cotidiana para resistir aos conflitos de interesses e a imposição de um sistema mundo cuja centralidade é o lucro. Esse mesmo sistema é produtor da pilhagem e da degradação socioambiental que se presencia nos dias atuais nos diversos setores da sociedade.

O reconhecimento da existência do conflito e a não aceitação de um modelo único para organização das sociedades na sua relação com a natureza e com o próprio homem, identificando as inúmeras injustiças produzidas nesses cenários, exigem capacidades produtoras de novas realidades e a soberania alimentar, identificada nas suas três dimensões, a saber política, técnica e territorial serão fundamentais para estabelecê-las. 


\title{
CAPÍTULO II - INJUSTIÇA SOCIOAMBIENTAL: CONCENTRAÇÃO DA TERRA E A SOBERANIA ALIMENTAR
}

\begin{abstract}
"O país inventou a fórmula simples da coerção laboral do homem livre: se a terra tinha que ser livre, o trabalho tinha que ser escravo; se o trabalho fosse livre, a terra tinha que ser escrava. O cativeiro da terra é a matriz estrutural e histórica da sociedade que somos hoje. Ela condenou a nossa modernidade e a nossa entrada no mundo capitalista a uma modalidade de coerção do trabalho que nos assegurou um modelo de economia concentracionista. Nela se apoia a nossa lentidão histórica e a postergação da ascensão social dos condenados á servidão da espera, geratriz de uma sociedade conformista e despolitizada. Um permanente aquém em relação ás imensas possibilidades que cria, tanto materiais quanto sociais e culturais" (MARTINS, 1979, pg. 2).
\end{abstract}

Nesse capítulo a partir da leitura da ecologia política e de estudos da questão agrária será demonstrado como conceitos de conflitos socioambientais e injustiça ambiental são descritores da realidade passada e presente no país, dificultando a constituição de uma sociedade verdadeiramente cidadã como reivindicada por Martins (1979) na abertura de chamada do capítulo. A constituição de impedimentos da maioria da população ao acesso aos recursos socioambientais é a marca fundadora e permanente de nossa sociedade desigual.

\subsection{INJUSTIÇA SOCIOAMBIENTAL - A CONCENTRAÇÃO DA TERRA}

A soberania alimentar pressupõe a territorialização do campesinato por meio do acesso e controle aos recursos naturais - terra, água, sementes, florestas, etc - respeitando a natureza. Esse é um dos eixos que estruturam a soberania alimentar concebida pela Via Campesina (EDELMAN et al., 2014; KLOPPENGURG, 2013, 2014), como vimos no capítulo anterior. Esse capítulo objetiva tratar como o acesso ao recurso terra tornou-se um dos principais conflitos socioambientais, histórico e hodierno, fundador da crescente desigualdade social no campo, com implicações no modelo excludente e profundamente injusto que deu forma a sociedade brasileira. Assim, trata de mostrar a luz da literatura disponível como o legado que marca o país até o presente momento cujo registro está marcado na estrutura concentrada da terra e nas desigualdades daí decorrentes como essa herança impacta a construção da soberania alimentar. 
Nesse sentido, a afirmação de Delgado (2017) sobre a transformação da terra em mercadoria pode nos trazer luz aos argumentos que nos faz compreender em que se baseiam os valores que nortearam a formação da estrutura fundiária no país. Assim vejamos:

A mercadorização absoluta da propriedade privada contém contradição insanável com a função social da terra, não apenas pela exclusão dos campesinatos, mas também pela exclusão das condições de vida civilizada nos espaços urbanos, e ainda pela emergência dos novos riscos ambientais que o domínio privado absoluto do espaço da natureza impõe a sociedade nacional e planetária em pleno século XXI.

Impor limites à liberdade de ação do capital sobre o espaço territorial, no seu estágio monopolístico, internacional e financeiro, é condição de possibilidade à própria democracia (pg. 102-103).

Esse processo de tornar os recursos naturais, em peculiar a terra, primeiro em propriedade particular e depois em meio de produção (RIBEIRO, 1991) foi possível pelo processo de produção capitalista que aqui entre nós teve configurações bastante singulares como assinala Martins (1979) na chamada de entrada desse capítulo. Sendo produto do processo de expansão capitalista europeia, ex-colônia de Portugal, a oligarquia agrária e o moderno agronegócio dos dias atuais, durante os últimos séculos, desenvolveram uma capacidade inventiva no que concerne à criação de instrumentos normativos que cerceiam o acesso aos recursos fundiários e territoriais aos pobres do campo e, ao mesmo tempo, desconsideram esses mesmos instrumentos quando esses possibilitam a garantia de direitos conquistados por esses mesmos sujeitos, na sua longa trajetória de constituição e resistência para permanecerem na terra.

De acordo com Martins (1981), a história de constituição do campesinato no país é uma história de retirantes, de migração intensa, provocada pela constante e contínua expropriação e exploração de famílias inteiras, submetidas a regimes e formatos de trabalho seja como agregados dos coronéis do Nordeste, seja no regime de colonato nas fazendas de café, como pequenos proprietários colonos no sul ou posseiros na Amazônia - cujo objetivo serviu a produção e reprodução do capital, primeiramente, nos sistemas de produção do café e da cana de açúcar, depois na reprodução de fazendas de café como também nos dias atuais, nas "modernas" fazendas dos empresários do agronegócio, cobrindo as atividades exigentes de mão de obra, como por exemplo, na colheita de café e frutos tropicais, como mão de obra temporária. Inovações sociais que permeiam a perpetuação de um poder senhorio, proprietário não apenas dos instrumentos de produção, mas sobretudo, do poder político de capturação mando, controle, institucionalização e favorecimento - do Estado brasileiro.

Os camponeses, eterno retirantes, resistem incansavelmente numa luta constante de reinvenção - muitas vezes às margens, por dentro e alimentando o próprio capital que o 
expropria - deixando sua marca nos rincões desse país, como parte do processo contraditório do sistema capitalista (MARTINS, 1981).

Isso só foi possível pela engenharia montada pelos instrumentos jurídicos criados a partir de 1850, com a instituição da Lei de Terras que impediu não apenas o acesso à terra aos milhares de escravos negros saídos do regime escravocrata, como também aos novos trabalhadores "livres" trazidos da Europa para substituírem a mão de obra escrava. Esse processo foi intensificado um século depois pelo Estatuto da Terra de 1965, que abortou o sonho de uma reforma agrária que poderia ter democratizado a estrutura fundiária no país (FERNANDES, 2012; MARTINS, 1979, 1981, 2000).

No World Inequality Report 2018, o Brasil figura como o segundo país mais desigual do mundo, acompanhado pelos países da África subsariana, com 55\% da renda nacional em poder dos indivíduos que ocupam os $10 \%$ do topo da pirâmide social, perdendo o posto de campeão em desigualdade para os países do Oriente Médio, ambos envolvidos em guerras civis e conflitos étnicos. Para os autores: "Having never gone through the postar egalitarian regime, these regions set the World inequality frontier ${ }^{35, "(A L V A R E D O, ~ 2017, ~ p g ~ 10) . ~ V a l e ~}$ salientar que esse indicador apresenta estabilidade no país desde a década de 1980, quando da elaboração do primeiro relatório.

O trabalho de Assouad et al. (2018), a partir de informações das contas nacionais, dados fiscais (declaração de imposto de renda) e dados de renda das famílias (PNAD), no ano de 2015, mostra quão desigual é a sociedade brasileira: os $10 \%$ dos indivíduos que estão no topo da pirâmide se apropriam de 55,3\% da riqueza produzida no país em forma de renda, os mais pobres que equivalem a $50 \%$ da população percebem um pouco mais de $12,3 \%$ e os $40 \%$ restante, que estão localizados no meio, percebem aproximadamente 32,4\% desse montante. Dentro de cada um desses grupos há intervalos que detalham de forma clara a expropriação das riquezas produzidas no país por poucos. Assim, o $1 \%$ mais rico consegue ficar com quase $30 \%(27,8 \%)$ de toda a renda nacional.

Outro relatório que também mostra a situação desigual que caracteriza o país e as diversas clivagens dessa desigualdade é o da OXFAM-Brasil (2017). Na abertura desse documento, os autores reconhecem assim como o relatório anterior que a desigualdade vem crescendo no mundo todo, mas entre nós essas características não são apenas díspares, mas, sobretudo, históricas, estruturais e contínuas, assim, afirmam:

\footnotetext{
35 "Nunca tendo passado pelo regime igualitário, essas regiões estabelecem a fronteira mundial da desigualdade" (em tradução livre).
} 
No Brasil, a situação é pior: apenas seis pessoas possuem riqueza equivalente ao patrimônio dos 100 milhões de brasileiros mais pobres. E mais: os 5\% mais ricos detêm a mesma fatia de renda que os demais $95 \%$. Por aqui, uma trabalhadora que ganha um salário mínimo por mês levará 19 anos para receber o equivalente aos rendimentos de um super-rico em um único mês (pg. 6).

Apesar do reconhecimento de que houve uma diminuição da pobreza entre a camada mais pobre da população, que está expresso na diminuição no índice de Gini ${ }^{36}$ para a distribuição de renda que passou de 0,616, no ano de 1988, para 0,515, no ano de 2015 . Contudo, a concentração de renda tem aumentado nas últimas décadas no topo da pirâmide social, especialmente porque os problemas das desigualdades estruturais tais como a taxação injusta e desigual, a concentração da terra e a desigualdade de oportunidades tem se aprofundado e afetado diferentemente as pessoas nas cinco regiões do país, como também no recorte por gênero e raça. Mesmo com a implementação de políticas importantes, na tentativa de diminuir tais injustiças, não alcançaram ainda os impactos necessários para construir resultados duradouros e ou simplesmente não foram realizadas no formato e na abrangência requerida como é o caso da Reforma Agrária (OXFAM-BRASIL, 2017; MATTEI, 2017; ALVOREDO et al., 2017).

Se a desigualdade de renda é assustadora, a disparidade na apropriação da riqueza não deixa por menos, é ainda pior. O relatório da OXFAM-Brasil traz dados reveladores sobre essa herança que consegue ser quase imóvel na sociedade brasileira pelo menos no que diz respeito à base da pirâmide. Assim, o relatório registra que $1 \%$ dos mais ricos no país centraliza $48 \%$ da produção da riqueza, representada pela propriedade da terra e bens imobiliários, bem como a posse de aplicações financeiras e ações. Do outro lado, os 50\% mais pobres possuem apenas $3 \%$ do que é produzido no país.

A riqueza de um país é produzida por toda a sociedade e não por indivíduos isoladamente, como reconhecem os autores desses relatórios, portanto, tais disparidades resultam das escolhas e caminhos políticos que as sociedades fazem, não é obra do destino ou da natureza. A pobreza e as desigualdades se reproduzem nos ambientes socioambientais, resultado da expropriação dos ambientes natural e social que são legitimadas no sistema capitalista em que vivemos (BLAKIE, 1987; RIBEIRO, 1991). E é exatamente sobre esse

\footnotetext{
${ }^{36} \mathrm{O}$ índice de Gini foi criado pelo estatístico italiano Corrado Gini, em 1912, objetivando medir desigualdade entre grupo de indivíduos, é um índice de comparação. Ele é utilizado para avaliar vários tipos de desigualdades, incluindo, a da distribuição de terra, variando de 0 a 1 . Quanto mais próximo de 0 mais igualitária é essa distribuição (terra, renda, riqueza), e mais próximo de 1, mais desigual. Há um amplo debate entre economistas e estatísticos sobre quais os índices que melhor expressam uma determinada realidade em comparação com os outros países, aqui faremos uso do que a bibliografia sobre a questão da terra se debruça e que a maioria das agências internacionais e órgãos oficiais utilizam para demonstrar as fraturas socioambientais (IPECE, 19--).
} 
processo de escolhas que Polanyi se refere quando discute a invenção do mercado autorregulável que transformou homem e natureza em mercadorias.

Todos os tipos de sociedade são limitados por fatores econômicos. Somente a civilização do século XIX foi econômica em um sentido diferente e distinto, pois ela escolheu basear-se num motivo muito raramente reconhecido como válido na história das sociedades humanas e, certamente, nunca antes elevado ao nível de uma justificativa de ação e comportamento na vida cotidiana, a saber, o lucro. O sistema de mercado autorregulável derivou unicamente desse princípio (POLANYI, 2012, pg. 31).

É essa lógica que produz e reproduz, continuamente, esses resultados e cabe a cada sociedade constituir suas escolhas ainda que inserida nesse contexto global. No caso do Brasil, em particular, seu legado guarda intensa relação com essa concepção de mundo e que tem profundos impactos que limitam as oportunidades de se constituir a soberania alimentar como veremos no decorrer desse trabalho. Martins (1981) chama a atenção sobre como é fundamental compreender como esse processo se desenvolveu entre nós:

É impossível entender a dinâmica de uma sociedade de classes, em suas determinações e singularidades, como a sociedade brasileira, tão diversa das sociedades de referência das tradições sociológicas, mesmo da de Marx, senão se leva em conta que a renda territorial ${ }^{37}$ é um dos fatores da diferenciação social e da constituição das classes e de seus antagonismos e conflitos (pg. 20).

Por isso mesmo, compreender o sistema e as instituições que asseguram, reproduzem e continuam a produzir uma sociedade profundamente desigual, até os dias atuais, é fundamental para fazer transformações necessárias e modificar nossa experiência societária atual. Segundo Martins (1979) o que assegurou a concentração da terra no país, após o fim do sistema das Sesmarias ${ }^{38}$, utilizado para a ocupação da colônia, foi uma legislação elaborada e implementada após o término do sistema escravocata no país que assegurou a elite oligarquica de então assenhorar-se do território nacional e, ao mesmo tempo, viabilizar a imigração de mão de obra barata, impossibilitando assim que outros sujeitos (ex-escravos negros e

\footnotetext{
${ }^{37}$ Assim explica o autor sobre as implicações da atualização do conceito de renda da terra pelo sistema capitalista onde a sociedade brasileira se insere: "Sendo a terra um fator natural, sem valor porque não é o resultado do trabalho humano, teoricamente não deveria ter preço. Mas, antes do advento do capitalismo, nos países europeus, o uso da terra estava sujeito a um tributo, ao pagamento de renda em trabalho, em espécie ou em dinheiro. Essas eram formas pré-capitalistas de renda decorrentes unicamente do fato de que algumas pessoas tinham o monopólio da terra, cuja utilização ficava, pois, sujeita a um tributo. $\mathrm{O}$ advento do capitalismo não fez cessar essa irracionalidade. Ao contrário, a propriedade fundiária, ainda que sob diferentes códigos, foi incorporada pelo capitalismo, contradição essa que se expressa na renda capitalista da terra. Tal renda nada mais tem a ver com o passado pré-capitalista, não é mais um tributo individual e pessoal do servo ao senhor; agora é um pagamento que toda a sociedade faz pelo fato de que uma classe preserva o monopólio da terra" (MARTINS, 1981, pg. 35).

${ }^{38}$ Primeiro regime de terras adotado no país o sistema das Sesmarias é extinto formalmente em 17 de julho de 1822 e no intervalo de quase 30 anos o país convive sem regulamentação jurídica até que em 1850 é aprovada a Lei de número 601 Euzébio de Queiroz de 18 de setembro de 1850 que vai dispor sobre as terras devolutas do Império e formas de regularizações, aquisições e concessões (SILVA, 1997).
} 
indígenas, os agregados das fazendas e pobres imigrantes que aqui chegaram) pudessem usufruir das riquezas de seu próprio trabalho porque desde então foram obrigados e submetidos a regimes de trabalho e expropriação similares aos sistemas de servidão experimentados em outras sociedades estamentais. Conforme Martins (1981) "O colono continuou a fazer exatamente o mesmo que o escravo fazia, mudando apenas a forma social da organização do trabalho, do trabalho coletivo do eito para o trabalho familiar" (pg. 5).

Assim, com o fim do período escravocata, foi instalado no país a Lei de Terras, datado de 1850, que institucionalizou a propriedade privada e impediu que ex-escravos e imigrantes supostamente livres - tivessem acesso aos recursos naturais, mais especificamente à terra. Sendo a terra, a mãe que embala o solo, os rios, as florestas e tudo o mais que a natureza oferece aos homens, como lugar de morada e trabalho, impedir o acesso a esse recurso é impedir a possibilidade da própria criação e reprodução. Foi esse engenhoso instrumento que permitiu a criação de regimes de trabalho - descrito pelo autor como colonato ${ }^{39}$, largamente empregado nas fazendas de café da época - para a expropriação dos imigrantes, intitulado então como colonos, e impediu a possibilidade de acesso à terra e aqui constituir formas autônomas de vida. Para acessar a terra, a qual a oligarquia obteve de forma gratuita, foram obrigados a trabalharem nas fazendas de café para pagamento de dívidas adquiridas no processo de migração e, quando possível, economizarem recursos para a aquisição de um pedaço de terra que pela nova Lei só seria possível por meio da compra (MARTINS, 1979).

Havia outros regimes de trabalho que conviviam com o regime escravocata, onde aos agricultores era permitido conviver no mesmo espaço, nas propriedades dos senhores de engenho, nas fazendas de plantio de cana de açúcar, especialmente no Nordeste do país, conhecido como agregados. A esses eram destinadas as atividades de abertura de novas áreas - derruba e queima da mata - considerada menos nobre para o trabalho da mão de obra escrava, onde estavam investido os recursos financeiros dos fazendeiros. Como nos relata Martins (1979), essa figura que tem perenidade entre nós, ocupou também as fazendas de gado pelos sertões do país, muitas vezes trabalhando ao mesmo tempo como vaqueiros e agricultores, até serem progressivamente expulsos nos contínuos processos de expropriações realizadas pelo latifúndio nas áreas ocupadas por esses. Além desses, tinham os posseiros que

\footnotetext{
${ }^{39}$ Martins (1981) afirma que esse regime não é um regime de trabalho assalariado, mas um regime que se constitui com características próprias, a saber, nas palavras do autor: "[...] pela combinação de três elementos: um pagamento fixo em dinheiro pelo trato do cafezal, um pagamento proporcional em dinheiro pela quantidade de café colhido e produção direta de alimentos, como meios de vida e como excedentes comercializáveis pelo próprio trabalhador, portanto, um componente camponês pré-capitalista na relação laboral. Além do que o colono não era um trabalhador individual, mas um trabalhador familiar, modo camponês de trabalhar, estranho ao mundo do assalariamento e aos requisitos de sua efetivação" (pg. 35).
} 
cumpriam a função de abrirem novas áreas - as chamadas áreas devolutas pertencentes ao Império - e os sitiantes que abasteciam o consumo interno das fazendas.

Martins (1989) identifica nesse movimento de expansão do capital no país o processo que deu origem ao campesinato brasileiro. Dessa maneira, ele carrega na sua identidade marcas dessa instituição, assim descreve o autor:

[...] o nosso camponês não é um enraizado. Ao contrário, o camponês brasileiro é desenraizado, é migrante, é itinerante. A história dos camponeses-posseiros é uma história de perambulação. A história dos camponeses-proprietários do sul é uma história de migrações [...ambos...] são determinados fundamentalmente pelo avanço do capital sobre a terra (MARTINS, 1989, pg. 17).

Logicamente esse ator social e político foi tomando forma nos séculos de descaso do Estado brasileiro, com que o campesinato em formação foi se constituindo e se transformando, tornando o legado (da expulsão) da concentração fundiária da terra em uma luta política com conteúdo e visibilidade social através das organizações políticas que conseguiram organizar no longo percurso de espera ativa - porque envolve uma história de lutas e conflitos - pelo acesso à terra. Assim, a luta pela terra como conteúdo político, transformou-se, desde a década de 1950 - 1960, na luta pela Reforma Agrária, sendo transformada pela elite econômica e política da época em um novo instituto jurídico denominado de Estatuto da Terra - Lei número 4504, de 30 de novembro de 1964 - durante o primeiro governo da ditadura militar (MARTINS, 1981; SILVA, 1997; FERNANDES, 2012; MATTEI, 2017).

O Estatuto da Terra que supostamente seria um instrumento para a realização da democratização da terra no campo brasileiro trouxe elementos que da perspectiva legal deveriam estruturar esse processo tanto do ponto de vista de valores fundamentais como de parâmetros operacionais para a realização da mesma. Contudo, o que aconteceu, largamente, foi a regularização e a concessão das terras devolutas e das grandes áreas de possessões irregulares, ou melhor dizendo, de grandes latifúndios irregulares para facilitar a distribuição de recursos financeiros por meio de crédito subsidiado, isenções e financiamentos para operacionalizar o pacote da revolução verde (SILVA, 1997).

Essa foi uma das formas largamente utilizada para transformar grandes latifúndios improdutivos no que hoje conhecemos como o moderno agronegócio. Ainda que o agronegócio de hoje não se restrinja apenas a esses antigos latifúndios na medida em que muitas das áreas pertencentes ao estado brasileiro foram concedidas nesse período a empresas multinacionais para implementarem o modelo agroexportador (FERNANDES, 2012). 
Junto com o golpe civil e militar, o Estatuto da Terra e o processo de modernização da agricultura que incluiu a mecanização agrícola, o uso intensivo de agrotóxicos, fertilizantes químicos e sementes melhoradas, o processo de expulsão dos camponeses foi acelerado com o deslocamento de milhares de famílias camponesas não só para os projetos de colonização na Amazônia, mas sobretudo, para as favelas das cidades do país. Portanto, o que se verificou nesse período foi a "grilagem especializada" conforme cunhou Silva (1997) no seu estudo sobre esse processo cujo legado histórico teve como base a apropriação privilegiada (alienação ou concessão) e a legitimação jurídica e formal questionável - na maioria das vezes - ilegítima na formação da propriedade privada desde a instauração da Lei de Terras, considerado o marco zero dessa atividade no país.

Gohn (2014) reconhece que após 25 anos da promulgação da Constituição, intitulada cidadã, uma das mais avançadas do mundo em termos de garantias de direitos sociais, o Estado brasileiro continua em dívida com reivindicações históricas e necessárias a plena realização de uma sociedade de fato democrática como a reforma agrária, a democratização da terra como a marca maior do processo histórico de exclusão deixado como legado para as gerações passadas, atuais e vindouras. Portanto, uma reivindicação que não pode se circunscrever aos camponeses que nela vivem e trabalham, mas, sobretudo, a uma sociedade que deseja igualdade de oportunidades e de vida para todos e não para uma minoria que vive da exploração e da expropriação dos recursos naturais e de seu povo.

Desse processo, resultam os dados da concentração fundiária atualmente no país que de acordo com Fernandes (2012) e medido pelo índice de Gini é de 0,854 e, de acordo com dados compilados pelo relatório da OXFAM Brasil (2016), é de 0,872. Ambos mostram o alto nível de concentração fundiária no Brasil e explicam o grau de intensidade e as diversas performances que esses atores produzem para perpetuar essas disparidades. Do total dos 5.175.489 estabelecimentos rurais, 805.587, ou seja, 15,6\% estão sob o domínio de empresas nacionais e multinacionais que concentram 249.690.940 hectares de terra, representando uma área de $76 \%$ das terras do país (FERNANDES, 2012). Essa concentração vem aumentando desde 2003, segundo esse mesmo relatório da OXFAM Brasil (2016).

A agricultura camponesa, representada por minifúndios - pequenas e médias propriedades - perfaz o total de 4.367 .902 estabelecimentos, ocupando uma área de 24,3\% (80 milhões de hectares) dessa área total (FERNANDES, 2012). Os minifúndios representam $65 \%$ desse universo e detém $8 \%$ da área total, 48,3 milhões de hectares que corresponde ao público, majoritariamente organizado pelo MPA (CADONÁ, 2004; IPEA, 2011). Essa configuração expressa a desigualdade contínua que os camponeses experienciam desde o 
processo de colonização do país, passando por diversas fases de consolidação do capitalismo no campo (MARTINS, 1979, 1981). Além de concentrarem terra, concentram riqueza, poder político e expropriação socioambiental, produzindo as desigualdades como legado histórico que se atualizam, em conformidade com a economia política da época, permanentemente com o apoio do Estado, fortemente, cooptado e personificado historicamente por este setor da sociedade nacional.

Ainda de acordo com Fernandes (2012) essa desigualdade no acesso à terra tem implicações e derivam outros impedimentos tais como: o acesso a um maior volume de recursos para o crédito e custeio para estruturar a produção, bem como apoiar os processos de comercialização; o acesso ao poder político e oportunidades para influenciar o desenho de políticas públicas que apoiem, em patamares similares ao que recebe historicamente o modelo agroexportador de commodities-mercadorias, a produção camponesa no país e seu enraizamento no território e, a imposição de um modelo padronizado de fazer agricultura baseado na monocultura, no uso de agroquímicos e na expropriação da autonomia camponesa. Dados do IBGE (2009) confirmam essas constatações, do crédito destinado ao setor, 13\% foram destinados para a agricultura camponesa e $87 \%$ para o agronegócio, os quais são responsáveis, respectivamente, por $38 \%$ e $62 \%$ do valor bruto da produção (FERNANDES, 2017).

Dessa forma, a desigualdade no acesso à terra se reproduz na captura da riqueza que é produzida no território expressa na distribuição desigual da renda. Assim afirma Fernandes (2012):

[...] em 3.775.826 estabelecimentos, vivem aproximadamente 11.3 milhões de pessoas que conseguem ficar com a ridícula soma de $4.03 \%$ da riqueza produzida e que as famílias de 2.014.567 estabelecimentos tem receita anual de até meio salário mínimo. A maioria dos estabelecimentos que fica com a menor parte da riqueza é da agricultura familiar (pg. 13).

Não é por acaso que a pobreza no país concentra-se largamente no meio rural, conforme dados do Programa Brasil sem Miséria (SAUER e FRANÇA, 2012). Apesar dessa realidade, são os camponeses que historicamente abastecem e alimentam a população brasileira conforme demonstram os dados do último censo agropecuário registrado pelo IBGE que confirma que as culturas que modelam a dieta alimentar dos ricos e pobres deste país tais como feijão, arroz, mandioca, café, milho, etc - é abastecida pela agricultura camponesa que também contribui na composição dos produtos da pauta de exportação comercializados no mercado externo tais como frango, laranja, café, fumo entre outros, seja na composição da 
produção propriamente ou como mão de obra temporária nas atividades de colheita e tratos culturais nas fazendas do agronegócio.

Mesmo assim, por conta do poder econômico capturar o poder político no país, as políticas agrícolas são desenhadas de modo a favorecer e impor o modelo agroexportador no território nacional que conforme os dados de OXFAM-Brasil $(2016,2017)$ faz parte de um dos fatores que impulsionam o modelo desigual de estruturação da sociedade nacional, além da elisão fiscal que distribui os custos a sociedade no seu conjunto (OXFAM-BRASIL, 2016, 2017).

A despeito do país ter uma porção de terra cultivada de cerca de 300 milhões de hectares, 35\% de todo o território nacional, o valor arrecadado com o Imposto Territorial Rural ${ }^{40}$ (ITR) representa menos de $0,06 \%$ do total arrecadado pelo Estado brasileiro. Ao mesmo tempo, há uma porção enorme de subsídios destinados aos proprietários de terra, e de maneira extremamente concentrada: apenas $9 \%$ dos estabelecimentos acessam 70\% de todos os recursos públicos destinados à produção agropecuária (pg. 49).

Do ponto de vista da elisão fiscal há um conjunto de Leis ${ }^{41}$ que "protegem" e favorecem o agronegócio tanto no âmbito federal quanto no âmbito dos estados onde ele ocupa majoritamente o território. Como afirma Fernandes (2012), quem ocupa o território determina o modelo de desenvolvimento de agricultura e pecuária que vai prevalecer nesses espaços. Nesse sentido, ainda que a Constitutição de 1988 tenha previsto o uso socioambiental da terra o que se vê é o espraiamento de um modelo quase unívoco das paisagens do país, ocupado por bois e monocultura. Dos 329,9 milhões de hectares, 48,1\% (158,8 milhões de hectares) dessa área são ocupadas por pastagens naturais e plantadas, sendo que $18 \%$ do território nacional estão concentrados pela atividade pecuária, enquanto as culturas abarcam 59,8 milhões de hectares (SILVA et al., 2011).

E todas as tentativas de distribuição de terras no país resultaram das lutas dos camponeses por meio de ocupações, marchas, negociações e várias formas de pressão organizadas e coordenadas pelos movimentos sociais do campo, com papel preponderante do MST. De acordo com Fernandes (2017) as reformas dos últimos governos, a saber, FHC, Lula e Dilma não correspondem a projetos, nem desses governos, nem concebidos pelos movimentos sociais, são produtos da correlação de força na sociedade e, mas que isso: "A reforma agrária atual não é somente uma luta contra o latifúndio, é também uma luta contra o

\footnotetext{
${ }^{40}$ O Imposto sobre a Propriedade Territorial Rural(ITR) foi criado pelo Estatuto da Terra, em 1965.

${ }^{41}$ Lei Kandir - Lei Complementar de número 87 de 13.09.1996 - isenta produtos primários e industriais semielaborados da incidência do ICMS (Imposto sobre Circulação de Mercadorias e Prestação de Serviços; Lei número 10.925 de 23.07.2004 - aplicação de alíquota zero para as contribuições de PIS-PASEP e CONFINS na importação e sobre a receita bruta da venda no mercado interno de insumos (adubos ou fertilizantes, agrotóxicosdefensivos agropecuários, sementes, corretivos de solos, entre outros (SILVA, 1997; PELAEZ et al., 2015).
} 
agronegócio. O latifúndio impede o campesinato de se territorializar, o agronegócio o destrói” (pg.248).

Por isso mesmo, o conceito de soberania alimentar considera relevante o território porque quem domina o território determina o modelo de agricultura do espaço. Portanto, como ressalta Martins (2000):

A questão agrária se redefine como forte componente da questão da soberania e não mais exclusiva ou principalmente como irracionalidade do processo de reprodução ampliada do capital. Redefine-se, pois, como questão política engendrada pela questão social, o que confirma a nossa tendência histórica de ter nos pobres e desvalidos os agentes sempre indiretos das ações demarcatórias da História, ainda que delas destinatários, mesmo que não reconheçam aí o seu "projeto social explícito" (pg. 123).

Nesse sentido, o projeto de soberania alimentar envolve aspectos tanto da questão histórica da concentração da propriedade da terra quanto questiona o atual modelo predatório de ocupação desse espaço que recebe amplo apoio e legitimidade por parte do Estado e de parcela da sociedade nacional, expropriando terra, vida e trabalho. Na atualidade há novos desafios para o enfrentamento dessa questão, portanto: "A reforma agrária não pode se ater à reivindicação das terras improdutivas sem colocar em questão o caráter socialmente perverso e ambientalmente predatório das terras produtivas" (SAMPAIO JÚNIOR, 2017, pg. 155).

\subsection{RECONCENTRAÇÃO DA TERRA OU INTENSIFICAÇÃO DA PRESENÇA DO CAPITAL?}

"A função econômica é apenas uma entre as muitas funções vitais da terra. Esta dá estabilidade à vida do homem; é o local da sua habitação, é a condição da sua segurança física, são as paisagens e as estações do ano. Imaginar a vida do homem sem a terra é o mesmo que imaginá-lo nascendo sem mãos e pés" (POLANYI, 2012, pg. 199).

Como foi visto no item anterior a questão agrária permanece não resolvida no país e vem incorporando novos elementos na contemporaneidade, como por exemplo, o ambiental, transformando-a num problema socioambiental e de soberania (MARTINS, 2000; SAUER e FRANÇA, 2012; MATTEI, 2017; DELGADO, 2017).

Na mesma direção, os movimentos sociais tradicionais como o MST e o próprio MPA que se originam da luta pela terra e por melhores condições de vida e trabalho, ambos passam a incorporar na sua agenda de mobilização o tema ambiental, transitando entre o seu projeto social anterior - fortemente ancorado nas suas reivindicações históricas e legítimas porque 
como vimos continua atual - e a busca por autonomia e justiça ambiental (WATTS e PEET, 2004; ACSELRAD, 2010).

Para outros, a questão da terra e do manejo dos solos estaria diretamente ligada a pelo menos três conjuntos de resoluções dentro do debate internacional sobre os Objetivos do Desenvolvimento Sustentável, a saber: as convenções das Mudanças Climáticas (ConvençãoQuadro das Nações Unidas sobre Mudança do Clima ${ }^{42}$ ), a da Diversidade Biológica ${ }^{43}$ (CDB) e a da Desertificação e Degradação da Terra (Convenção das Nações Unidas de Combate à Desertificação) (VAN DER ESCH et al., 2017). Portanto, um contexto complexo, no qual interage inúmeros conflitos de interesses e entendimentos diversificados.

Há um relativo número de atores e cientistas que vem se debruçando na produção de dados relativos aos danos ambientais associados aos modelos predatórios que as escolhas societais produziram no último período relacionado com a degradação dos recursos naturais, fartamente mobilizados para a exploração agropecuária e para a acelerada urbanização e industrialização (HECHT, 1985; SILVA, 2011; FAO, 2015; BOMBARDI, 2011, 2013, 2017).

Na década de 1980, Hecht (1985) chamava a atenção para o nexus da relação ambiente-desenvolvimento-política na acumulação de capital no setor agropecuário na Amazônia Oriental, durante o período da ditadura militar, que se creditava (e muitos ainda o creditam) o desmatamento a falta de tecnologias e a pobreza dos pequenos agricultores e colonos que foram expulsos de suas terras de origem para a ocupação dos projetos de colonização patrocinados pelo Estado brasileiro. Seu estudo mostrou que a degradação ambiental estava associada com a implantação de largas áreas de pastagens para a captura da terra com apoio de subsídios governamentais, objetivando a criação do mercado de terras e sua subsequente especulação, na Amazônia brasileira. Assim conclui a autora:

The productivity of the land became secondary because the land itself was the commodity. Due to the peculiarities of state subsidies, a radical disjuncture between the value of land for production and its value for exchange was created. If the productivity of the land itself has little importance, cautious land management

\footnotetext{
${ }^{42}$ Resultado das articulações realizadas durante a Conferência das Nações Unidas sobre Meio Ambiente e Desenvolvimento, em 1992, conhecida como Conferência do Rio, as três convenções tem datas e processos diferenciados. Assim, a CMC passa a vigorar em 1994 e sua sigla em inglês é UNFCCC; a CDB cuja sigla em inglês é CBD, entrou em vigor no final de 1993; por fim, a UNCCD que é a sigla em inglês que designa a Convenção de Combate à Desertificação passou a ter validade em 1996. Como afirmam Ribeiro e Sant'Anna (2012) essa forma de operar na escala internacional por meio do que intitulam governança da ordem ambiental internacional apresenta vantagens e desvantagens, portanto portadoras de reformulações. No entanto, avaliam os autores, a criação de novas institucionalidades não irão resolver os limites do funcionamento das instâncias e compromissos aí criados, caso as economias centrais no âmbito internacional não mudarem o comportamento de recusa no compartilhamento de compromissos e responsabilidades, bem como no pagamento das reparações das desigualdades socioambientais, objetivando "[...] reorganizar o mundo degradado do modelo hegemônico de produção de mercadorias” (RIBEIRO e SANT’ANNA, 2012, pg. 66).
} 
becomes irrelevant, and environment degradation is the inevitable result $(\mathrm{HECH}$, 1985, pg. 680).

Na década dos 1980, no país, a questão ambiental ainda não havia se tornado um assunto de interesse como presenciamos hoje, mas já havia preocupações em vários setores da sociedade com relação aos processos de degradação dos recursos naturais como vimos no capítulo anterior. Sobretudo, o forte movimento para excluir as populações locais dos espaços considerados quase 'intocáveis' e é nesse contexto que o trabalho de Hech (1985) e Blaikie (1985) se insere.

Ainda assim, quase quarenta anos depois, no relatório da FAO (2015) sobre o estado dos solos no mundo, elaborado pelo ITPS ${ }^{44}$ (Intergovernmental Technical Panel on Soils) sob a coordenação dessa organização, em 2015, para o ano internacional dedicado a esse recurso, avaliou-se que, apesar do número de evidências sobre a degradação dos solos, há uma enorme lacuna em termos de mensuração e qualificação dos impactos e das alterações na biota ${ }^{45}$ do solo em decorrência da intensificação de seu uso, seja pelas diferentes agriculturas e sistemas pecuários ao redor do mundo, seja pelos outros usos. Sendo pouco visível, passa despercebido pela sociedade. Uma das razões citadas no referido relatório para tal situação é o alto custo para o desenvolvimento de pesquisas nessas áreas.

Por outro lado, não há interesse do capital, que explora os solos no mundo, conhecer os resultados gerados pela sua própria (explor)ação. Além disso, as estimativas apontam que mais de $50 \%$ das terras livre de gelo sofreram alterações, isso representa 70 milhões de $\mathrm{km}^{2}$. E as terras degradadas já representam $24 \%$ da área, 35 milhões de $\mathrm{km}^{2}$, sendo que a maior parcela está representada pelas florestais (FAO, 2015).

Sabe-se, a partir do aporte das tecnologias de GIS (sistemas de informações georreferenciadas), que mapeiam ao redor do globo a ocupação do território com as principais atividades desenvolvidas pelo homem que naquele ano - 2015 - o quadro era o que segue: 0,6\% está coberto com superfícies artificiais; 12,6\% com culturas; $13 \%$ com pastagens; 27,7\% com florestas arbóreas; 9,5\% vegetação arbórea; $1,3 \%$ vegetação herbácea; $0,1 \%$ manguezais; 7,7\% vegetação escassa; $15,2 \%$ solos sem vegetação (nus); 9,7\% neve e gelo; 2,6\% corpo de águas. Importante salientar que essas ferramentas não reproduzem com

\footnotetext{
${ }^{44}$ Painel Técnico Intergovernamental sobre Solos (ITPS) - sigla em inglês.

${ }^{45}$ Uma iniciativa ao redor do tema, lançada em 2011, é a Global Soil Biodiversity Initiative - Iniciativa Global para a Biodiversidade do Solo - uma plataforma para a divulgação do conhecimento científico e a produção de políticas que aportem subsídios na área de serviços ecossistêmicos e reúne pesquisadores de várias partes do mundo (https://globalsoilbiodiversity.org/content/what-global-soil-biodiversity-atlas). Última consulta em 12.02.2018.
} 
precisão o estado real desses territórios, portanto, são todos dados aproximados (FAO, 2015). Isso significa dizer que florestas, pode não ser exatamente uma floresta, mas uma monocultura de eucaliptos, por exemplo.

De acordo com a FAO (2015), entre os principais impulsionadores da degradação desse recurso estão: dinâmica populacional, mercado de terras, crescimento econômico, guerra e conflitos civis, políticas locais e nacionais e mudanças climáticas. Em quaisquer dessas situações a atividade agropecuária e sua demanda por terra são afetadas (SILVA et al., 2011; FAO, 2015).

No Brasil, em particular, segundo Silva et al. (2011), o setor de LULUCF ${ }^{46}$ é responsável por cerca de $55 \%$ do total das emissões de gases de efeito estufa, em grande medida decorrente dos desmatamentos. De acordo com dados do IBGE (2006), o território nacional possuía um percentual de 2,98\% (9.842.925 milhões de hectares) de pastagens degradadas ${ }^{47}$ e 0,24\% (789.238 milhões de hectares) de terras degradadas, estando aí incluídas, áreas erodidas, com processos de desertificação, salinização, entre outros. O fato é que, considerando os dados disponíveis sobre a situação atual da erosão, degradação e contaminação dos solos no mundo, alguns cientistas acreditam que é necessário modificar o status desse recurso: "The large difference between erosion rates under conventional agriculture and soil formation rates implies that we are essentially mining the soil and that we should consider the resource as non-renewable" (FAO, 2015, pg.103).

Os problemas arrolados como resultado das atividades agrícolas vai desde a compactação, salinização, desertificação, contaminação, entre outros, todos afetando a biodiversidade do solo - bactérias, fungos, protozoários, insetos, etc - que impactam diretamente a produção de alimentos. Mesmo assim, não há, na maioria dos países, nenhum sistema de monitoramento e avaliação sistemática desses processos ${ }^{48}$. E a situação na América Latina, morada de oito dos dezessete países considerados mega-diversos - Bolívia, Brasil, Colômbia, Costa Rica, Equador, México, Peru e Venezuela - não é menos preocupante. Para o caso do Brasil em particular, a área irrigada no Nordeste do país já

\footnotetext{
${ }^{46}$ Uso da terra, mudanças no uso da terra e florestas.

${ }^{47}$ Do total das terras em uso, ou seja, 329.971 .728 milhões de hectares.

${ }^{48}$ A falta de monitoramento e avaliação sistemática dos recursos naturais não é um problema exclusivo do recurso solo, mas, por exemplo, a água que é visível e cujos sistemas afetam cotidianamente e diretamente a vida de todos, apresenta situação não muito diferente. Dados de Machado et al. (2016), em uma pesquisa desenvolvida em 20 das 27 capitais do país, sobre a presença de contaminantes emergentes de diferentes classes - hormônios, plastificantes, herbicidas, triclosan e cafeína, que sequer estão considerados na legislação com relação a qualidade da água - na água potável, demonstrou a larga presença de cafeína e atrazina nas amostras que foram coletadas e avaliadas, indicando a deficiência do saneamento básico e dos tratamentos da água empregados em diferentes capitais brasileiras.
} 
apresenta cerca de 500 mil hectares de áreas - que representa 25-30\% dessa área - em processo de salinização (HEINZE, 2002). Portanto, há forte indicativos que esse modelo de agricultura necessita ser revisto.

Portanto, a expansão da produção para exportação significa não apenas a exportação das commodities em si, mas sobretudo, de outros bens, como os solos e a água. Segundo Sauer e França (2012) apoiados na literatura de França e Cardoso Neto (2006) para a produção de $1 \mathrm{~kg}$ de grãos são necessários cerca de 1 metro cúbico de água, esses ditos ‘custos' não entram na contabilidade do agronegócio, mas entra nos custos da nação, pois esses são recursos de uso comum, pertencentes ao povo brasileiro e apropriado pelos empresários do agronegócio. De certo que a produção agropecuária não contabiliza os custos socioambientais que essa atividade acarreta, pois que são distribuídos socialmente (FURTADO, 2003).

Bombardi (2011, 2013 e 2017) tem confirmado nos seus trabalhos sobre o uso de agrotóxicos no país que há uma ligação direta entre a expansão-territorialização do agronegócio $^{49}$, o crescente número de casos de notificação de intoxicação de camponeses e trabalhadores rurais por agrotóxicos - no cotidiano de seu trabalho - e a atuação do Estado por meio de normativas fragéis comparada com legislações mais restritivas nos países europeus, na produção de uma violência silenciosa e mortal. A escalada do uso de agrotóxicos no país é resultado dessa permissividade e do compromisso do Estado brasileiro com o agronegócio multinacional (PELAEZ et al, 2015; BOMBARDI, 2017). Dados do ano de 2000, mostram o consumo de 170.000 toneladas de venenos, já em 2014 esse volume aumentou para 500.000 toneladas, representando um crescimento de $135 \%$. Desse total, $72 \%$ são consumidos pelas culturas de exportação tais como soja, milho e cana de açúcar (BOMBARDI, 2017).

Além disso, Pelaez et al. (2015) salientam que não há sistemas de monitoramento e de controle sistemáticos sobre os impactos do uso desses produtos nem no ambiente, muito menos na saúde humana. Os registros das ocorrências são optativos, realizados pelos dois sistemas que existem - SINITOX-FIOCRUZ e SINAN $^{50}$ - portanto, nem os empregadores, nem as pessoas que adquirem esses produtos como, por exemplo, camponeses ou outros

\footnotetext{
${ }^{49}$ Segundo Bombardi (2013) esse negócio mobilizou uma soma de 15 bilhões de reais - conforme consta no Anuário do Agronegócio 2010 da Revista Globo Rural - e expressa o mecanismo oligopolístico de organização das empresas ligadas a este setor.

${ }^{50}$ SINITOX - Sistema Nacional de Informações Tóxico-Farmacológicas, coordenado pela Fundação Osvaldo Cruz-FIOCRUZ e interligado pela Rede Nacional de Centro de Informação e Assistência Toxicológica (Renaciat), criado em 1980 (https://sinitox.icict.fiocruz.br/). O SINAN - Sistema Nacional de Agravos de Notificação, ligado ao Ministério da Saúde e operado pelas secretarias municipais de saúde dos municípios e estados (http://portalsinan.saude.gov.br/). Última consulta 14.02.2018.
} 
indivíduos, não são obrigados a notificarem, caso algum tipo de acidente ocorra (BOMBARDI, 2017).

A dimensão do problema não é pequena na medida em que o país faz uso de um quinto de todo o agrotóxico vendido no mundo e o número de pessoas infectadas, mesmo considerando a fragilidade dos sistemas de registro e monitoramento, vem aumentando progressivamente. Segundo dados de Bombardi (2017), em 7 anos - no período de 2007 a 2014 - foram registradas 25 mil ocorrências de intoxicações, o que sugere uma média de 3.124 ao ano e oito ao dia, na contabilidade da autora. Pelaez et al. (2015) fazem uma síntese que expressa a situação contínua sobre o tema no país:

Se, por um lado, os aspectos ligados à regulação social dos agrotóxicos têm sido negligenciados pelo poder público, por outro, tem-se mantido o foco na política de incentivo ao consumo desses produtos por meio da desoneração fiscal. A isenção de IPI permanece por meio do Decreto n. 2.006/06. E a Lei Complementar n. 24 de 1975 determinou a possibilidade de isenções do imposto sobre circulação de mercadorias a partir de convênios celebrados entre a União e os Estados. No caso dos agrotóxicos, os convênios firmados desde então determinam uma redução de 60\% nesse imposto. E o Decreto n. 5.630/2005 isentou a contribuição para o PIS/Pasep e Cofins incidentes na importação e na venda do mercado interno dos agrotóxicos. Existe ainda uma proposta de isentar os agrotóxicos de todos os impostos por meio de uma Emenda Constitucional (PEC 491-B de 2010) (pg. 162).

Portanto, é um modelo produtivo sem nenhuma responsabilidade no trato com questões socioambientais e, ainda assim, conta com apoio incondicional do Estado que parece de costas para os impactos que tal modelo vem produzindo e reproduzindo no território nacional.

Esse processo só se agrava, vide a reforma aprovada pelo Congresso Nacional e confirmada pelo STF - Supremo Tribunal Federal - do Código Florestal brasileiro, um exemplo emblemático sobre o que está por vir. Como afirmam Sauer e França (2012) o conceito de área rural consolidada é o próprio reconhecimento do "perdão dos desmandos em termos socioambientais" é a comprovação da 'anistia do passivo ambiental', concluem os autores. Seria necessário, de acordo com Sauer e França (2012) ter assegurado o que está expresso no texto constitucional, ou seja: “... o caráter socioambiental da terra e não meramente seu uso e sua exploração econômica" (pg. 298), que foi o que não ocorreu nessa reforma.

Vivemos em um mundo em processo intenso de contradições. Em certo sentido a questão ambiental colabora no sentido de dar visibilidade e organizar críticas concretas do processo de degradação produzidas nos processos de produção do capital. Por outro lado, muitos agentes desse mesmo capital tem se organizado fortemente em torno do que se 
convencionou chamar de economia verde ou economia ambiental, intensificando as disputas territoriais (MARTINEZ-ALIER, 2007).

Por isso, na análise dessa profusão de dados sobre as diversas crises ambientais atuais, devemos considerar as lições provenientes do trabalho de Blaikie e Brookfield (1987) que consideram que a:

Land degradation should by definition be a social problem. Purely environmental processes such as leaching and erosion occur with or without human interference, but for these processes to be described as 'degradation' implies social criteria which relate land to its actual or possible uses (pg. 1).

Os trabalhos de Blaikie (1985) e Blaikie e Brookfield (1987) levantam uma questão preponderante sobre a influência política acerca de como o ambiente é medido. Que medidas são relevantes serem visibilizadas e consideradas na elaboração de políticas ambientais, especialmente, para as populações marginalizadas, no sentido de legitimar o controle do Estado sobre os recursos e as pessoas, e de quais políticas interessa financiar, entre outros aspectos. Portanto, há uma discursividade científica que legitima os desdobramentos das iniciativas baseadas nos fatos e eventos da crise ambiental. Não se pode esquecer que os problemas ambientais são mediados pelo poder e pelos conhecimentos, especialmente, o científico (BLAIKIE e MULDAVIN, 2004).

Vejamos, por exemplo, para o caso específico da perda da biodiversidade, em que um volume considerável de recursos são mobilizados por ONGs do Norte para essa agenda que é definida globalmente e cujos recursos destinam-se para a proteção de espécies que na escala regional ou local certamente seriam eleito outras prioridades como, por exemplo, para o caso específico do estudo ora em apreço, ou seja, a proteção dos territórios camponeses, seus modos de vida e suas sementes. Portanto,

The environment is socially constructed because what we notice, interpret and give meaning to comes from our direct experience and our cultural repertoire (value, systems, traditions, religions, educational contents, etc.). Any environment conceived of and experienced at the local, regional, national and international level is the focus of a wide cast of actors who will bring to it a variety of constructions. In so doing they enter into discourses, not only about the environment narrowly defined by a natural scientist, but about symbolic as well as physical aspects of it that reach into our daily cultural, and actors will attempt to enroll others into their projects by any means at their disposal. The political playing field has gradients which derive from structures of power at all levels. Such a standpoint, that encompasses both the environment and those who interpret and modify it, leads to an acknowledgement of multiple views. Appeals to better environmental science, to law and order and the logic of the market will be able to press their cases, but they too are subject the same plurality (BLAIKIE, 1995, pg.212-213). 
Como foi anteriormente importante o discurso da escassez de alimentos ou da fome reiterado quando interessa - e a revolução verde como projeto de desenvolvimento ideal para saná-la com discursividade científica em vários campos do conhecimento, hodiernamente, o discurso ambiental, embora eivado de incertezas científicas, vem determinando diversas políticas ambientais, no qual a ordem do mercado, como dantes, nas promessas de reduzir a fome, dá o conteúdo e as medidas.

Como Blaikie (1985) alerta, os processos físicos, na maioria dos casos, somente podem ser entendidos em termos de economia política ${ }^{51}$. Portanto, o problema ambiental não existe separado da constituição discursiva que tanto os especialistas quanto o poder do Estado nesse campo, acoplado com práticas tecnológicas de pesquisa e seus artefatos, mercado e regulamentações produzem. Muitos desses dados deram bases para a formulação de políticas ambientais restritivas e excludentes e reforçaram a exploração comercial no lugar de apoiarem os usos históricos das populações locais para sua sobrevivência, como por exemplo, a conservação da agrobiodiversidade ${ }^{52}$ praticada pelos camponeses com os recursos que manejam, sejam plantas ou animais. Por isso mesmo, as comunidades locais, bem como os movimentos sociais constroem suas próprias concepções desses problemas ambientais e suas formas de resistências (ROBBINS e BISHOP, 2008).

Assim, o debate em torno do que vem sendo constituído como Land grabbing ${ }^{53}$ (apropriação de terras) e Green land (apropriação verde) que para alguns autores tem impacto direto no debate sobre a questão da terra e suas novas formas de captura nos interessa particularmente, pois influencia as formas de resistência do campesinato nas questões que aqui nos interessa, a continuidade de sua territorialização e a garantia da soberania alimentar (KELLY, 2011; FAIRHEAD et al., 2012; SAUER e BORRAS JÚNIOR, 2016).

Alguns autores argumentam que as últimas crises no sistema capitalista, denominadas de crise alimentar, energética e ambiental, cujo marco se dá no ano de 2008, tem mobilizado alguns atores na corrida pela apropriação de terras, especialmente, nas regiões tropicais (FAO, 2015; BOECHAT et al., 2017; SAUER e BORRAS JÚNIOR, 2016). Assim, o termo Land

\footnotetext{
${ }^{51}$ Nas palavras do autor: "We argue that the scientific inquiry which informs decisions about resource use should not be thought of as isolated from conflicts over the resource, for scientists to have ideas and aims which clash with those of other groups, and there is no autonomous science operating independently from the political economy in which it is practice" (ABEL and BLAIKIE, 1986, pg. 736).

${ }^{52}$ Como nos lembra Yapa (2002): "[...] hybrid seeds are not simply a technique of increasing food production, but represent the emergence of a mode of production that is destroying the productive base of subsistence" (pg. 78).

${ }^{53}$ Segundo dados da FAO (2015), desde 2000, foram registrados aproximadamente 1000 acordos envolvendo diversas formas de aquisição de terras por investidores estrangeiros, ao redor do globo, envolvendo cerca de 55 milhões de hectares relacionados a projetos agropecuários (40\%), agrocombustíveis (10\%) e projetos florestais, expansão urbana, mineração, projetos de infraestrutura, turismo e outras atividades (50\%).
} 
grabbing descreve esse processo que envolve a inteira alienação da terra para a expansão da produção agropecuária com objetivos para além da produção alimentar, que envolve a expansão dos plantios de agrocombustíveis, no intuito de substituir as energias fósseis, como também a ampliação de plantio de monocultivos de árvores (FAIRHEAD et al., 2012).

Segundo Boechat et al. (2017) há três aspectos envolvidos no fenômeno do land grapping, a saber: uma dimensão de poder envolvida no controle da terra e dos recursos a ela associado; estratégias envolvidas na dinâmica de acumulação do capital e a ascensão de múltiplos usos dos recursos naturais. Ambos ligados aos discursos da insegurança alimentar cujo objetivo é aumentar a produção de alimentos; a insegurança energética e a produção de agrocombustíveis que atenderia ao mercado ambiental e por fim, a implementação de novos empreendimentos chamados de infraestruturas para atender a circulação de mercadorias, financiados pela ação de especuladores fortemente representado pelos fundos de pensão e por acionistas de capitais privados, incentivados pela profícua produção de regras, regulamentações e incentivos da comunidade internacional ambígua.

Para Boechat et al., (2017) a renovação dos mecanismos de apropriação de terra adquire sentido social e histórico distinto do que já teve, objetivando lucros na forma de renda da terra. Não tendo mais a indústria para absorver a mão de obra que será expulsa do campo, por certo os camponeses irão perder a segurança que ainda possuem, mesmo em condições desfavoráveis.

Oliveira (2010) afirma de maneira contundente que esse processo não é novo, mas sim uma continuidade e que falta robustez aos estudos que vem descrevendo tal mecanismo como novidade, na medida em que se apoiam em relatórios internacionais de prospecção de demandas sobre a expansão de áreas destinadas ao aumento da produção, com base no trio da crise alimento-energia-ambiente. Segundo o autor, os setores do agronegócio não atuam da mesma maneira no tocante a ocupação de terras.

[...] setores [de silvicultura e sucroenergético] atuam na lógica da territorialização do monopólio, quer dizer, atuam no sentido de produzirem em terra própria senão a totalidade, pelo menos a maior parte da matéria prima que necessitam. Diferente é o que ocorre nos demais setores do campo, como por exemplo, o setor de grãos, onde os grandes monopólios - ADM, Cargill, Bunge, LDC, etc.- não produzem os grãos que monopolizam em terras próprias, por certo nem as tem. Ao contrário, dos setores da silvicultura e sucroenergético, no setor de grãos ocorre o processo de monopolização do território, pois nele há uma aliança de classe entre a burguesia mundial e a burguesia agrária brasileira que pode ou não ser também, proprietária de terras. Este processo ocorre nos demais setores da agropecuária brasileira e mundial, como aqueles dos diferentes tipos de carnes, leite, citrícola, café, etc. Logo, a presença de empresas e ou estrangeiros produzindo diretamente nestes setores no Brasil, sempre existiu, porém, nunca representou qualquer ameaça a segurança da 
pátria. Mesmo porque o capital mundial, inclusive com presença de empresas igualmente mundiais, controlam a economia brasileira (OLIVEIRA, 2010, pg. 79).

O que há de fato, segundo Oliveira (2010) é um vínculo entre o capital nacional e o estrangeiro, cujas profundas mutações ocorrem desde a década de 1980 e 1990, tendo na $\operatorname{Cosan}^{54}$, seu exemplo emblemático. Assim, descreve o autor:

Com a constituição da Cosan (uma aliança entre a família Dedini e parte da família Ometto) a empresa lançou ações nas bolsas de valores nacional e internacional, comprou a Esso Mobil no Brasil e depois constituiu joint venture com a Shell, dando origem à Raizen. Ninguém comprou ninguém apenas aliados associaram-se no mesmo negócio (OLIVEIRA, 2010, pg. 80-81).

A argumentação de Oliveira (2010) é que há sim um processo de reorganização do capital no campo, mas que diz respeito à financeirização da agricultura. Para o autor, a abertura de capital da SLC Agrícola ${ }^{55}$, em 2007, representou o marco dessa nova configuração, mais complexo, oligopolizado e com vários setores vinculados.

A abertura do capital da SLC Agrícola, em 2007, é uma espécie de marco desse novo movimento, pois, foi a primeira empresa constituída por fazendas produtoras de grãos do mundo que tem suas ações negociadas em bolsas. Como parte do Grupo SLC, constitui-se em uma empresa produtora de commodities agrícolas (algodão, soja e milho). Possui onze fazendas de produção no MS, MT, GO, BA, PI e MA com 230,7 mil hectares cultivados na safra de 2010-2011, sendo 118,2 mil de soja, 85,0 mil de algodão, 24,8 mil de milho e 2,6 mil café, trigo e milho semente (OLIVEIRA, 2010, pg. 85).

Há uma complexidade na ação hodierna do agronegócio que envolve aspectos além do que os olhos possam enxergar, ainda que ele continue na sua essência como descreve Oliveira (2010), o mesmo, ou seja: “[...] o agronegócio de moderno só tem a tecnologia, pois suas relações sociais de produção continuam entre a barbárie e o agrobanditismo"(pg. 95).

\footnotetext{
${ }^{54}$ A Cosan é uma empresa que inicia suas atividades no ano de 1936, em Piracicaba (SP), no setor sucroenergético. Como consta no site da companhia: "A Cosan é uma das maiores empresas do Brasil, com investimentos em setores estratégicos como agronegócio, distribuição de combustíveis e de gás natural, lubrificantes e logística. Ao longo de seus mais de 80 anos de história, a Cosan diversificou sua atuação e atualmente seu portfólio reúne grandes empresas como Raízen Combustíveis, Raízen Energia, Comgás, Moove e Rumo, líderes em seus respectivos setores" (www.cosan.com.br/pt-br/cosan/historia). Última consulta: 31.03.2018.

${ }^{55}$ De acordo com as informações disponibilizadas na página da empresa, as operações cresceram. Assim, vejamos, a SLC Agrícola foi fundada no ano de 1977 e é uma das maiores empresas do setor, focada na produção de soja, algodão e milho. A empresa possui 14 unidades de produção, distribuídos em 6 estados brasileiros, perfazendo um total de 377 mil hectares plantados na safra 2015-2016, assim distribuídos: 211,4 mil de soja; 93,6 mil de algodão, 60,9 mil de milho e 11,2 mil de outras culturas - girassol, trigo, milho semente, soja semente e cana-de-açúcar. A operação da empresa se dá em terras próprias, em terras arrendadas e pela aquisição de terras brutas para transformação e venda. No caso desta última operação, realizada pela subsidiária SLC LandCo, criada em 2012, com o fundo de investimentos privados inglês Valiance, é o braço da empresa que trabalha exclusivamente na aquisição e vendas de terras. Assim está descrito o modelo de negócio da SLC: "O modelo de negócio é baseado em um sistema de produção moderno, com alta escala, padronização das unidades de produção, tecnologia de ponta, controle rigoroso dos custos e responsabilidade socioambiental" (https://www.slcagricola.com.br/quem-somos/). Última consulta 31.03.2018.
} 
Por outro lado, o Green land corresponde às práticas de reestruturação de regras e autoridade no acesso, uso e manejo dos recursos que podem ter profundos efeitos de alienação, neste caso em nome do ambiente. Este termo utilizado pelos autores diz respeito exclusivamente à captura de terra ou expropriação para fins da agenda dita ambiental e sustentável, ou seja, para fins que envolvem atividades em torno da conservação da biodiversidade, sequestro de carbono, a proteção de serviços ecossistêmicos, ecoturismo etc. Nesse processo, explicam os autores, nem sempre está envolvida a inteira alienação entendida como a apropriação, enquanto a mudança da propriedade da terra, seja do Estado ou de indivíduos, mas também modificações nas regras e na administração do acesso, no uso e manejo de recursos, nas relações de trabalho, portanto nas relações do homem com a natureza (FAIRHEAD et al., 2012).

Para Fairhead et al., (2012) através do globo, os ecossistemas estão à venda, agora representado por uma gama de atores que vai desde especuladores à ambientalistas (fundos de pensão, comerciantes de commodities, companhias de ecoturismos, entre outros ${ }^{56}$ ). Esse movimento que parece ser novo, representa um novo tipo de neo-colonialismo, conforme descrevem os autores que a partir dos acontecimentos na Àfrica, Ásia e América Latina pode ser observado.

Fairhead et al. (2012), também chamam atenção sobre a base do discurso que permite ligar a captura da terra e os mercados de commodities ambientais, a saber, a ciência, a tecnologia e a política.

"There would be no enclousures for biodiversity without the scientific and
discursive processes that identified its global significance and threatened status
(Corson and MacDonald, 2012). There would be no 'payments for ecosystem
services' (PES) without the particular framing of late-twentieth century global
environmental problems by the Millennium Ecosystem Assessment (2005), the
science-policy assessment that spawned the PES concept (Corbera et al. 2007,
Redford and Adams 2009, Nature 2009, McAfee and Shapiro 2010, Kosoy and
Corbera 2010)57 (FAIRHEAD et al., 2012, pg. 241).

\footnotetext{
${ }^{56}$ Oliveira (2010) chama a atenção para esse fenômeno já presente no pais relacionado com as fusões das multinacionais do setor do agronegócio: "É necessário destacar que muitos desses processos de fusões, associações e aquisições foram feitas com a participação do BNDES e dos fundos de pensão dos trabalhadores das estatais brasileiras. Aliás, os fundos de pensão dos empregados das estatais têm se tornado proprietários de parte das ações de muitas empresas no Brasil, revelando sua dimensão capitalista. Ou seja, esta parte do proletariado tem interesse na lógica capitalista de produção desses empreendimentos onde são acionistas, às vezes, até tornando-se majoritários como é o caso da Vale" (pg. 83).

57 "Não haveria nenhum mercado de carbono sem uma política científica discursiva que distinguiu o aquecimento global. Não haveria nenhum cercamento (áreas restritas) para a biodiversidade sem um processo científico e discursivo que identificasse seu significado e status global de ameaça. Não haveria nenhum 'pagamento para serviços ecossistêmicos'(PSA) sem uma estrutura particular dos problemas ambientais do final do século XX pela Avaliação dos Ecossistemas do Milênio (2005), a política científica da avaliação gerou os conceitos da PSA"(FAIRHEAD et al., 2012, pg. 241) - (Tradução livre).
} 
Os autores reconhecem que esse movimento se ampara amplamente na ciência, seja na economia, na biologia ou na ecologia, para transformar a natureza em um negócio profundamente lucrativo, desconsiderando os efeitos diversos, diferenciados e contingentes que produzem nas relações sociais e culturais onde tais empreendimentos serão ou estão sendo implementados. Portanto, considerar a relação entre a produção científica ou a política científica mundial que estabelece essas novas formas de mercadorias-commodities e a captura pelos mercado de capital e seus efeitos sobre as populações aí inseridas, especialmente, os camponeses, populações indígenas e tradicionais é fundamental porque são novas formas de justificação para velhas práticas de expropriação da terra, ou seja, uma atualização de um legado que se renova. Assim, essas novas valorações também têm trazido novas especializações da natureza e novos potenciais para desigualdades.

Há um intenso processo de legitimação do Green grabs que se dá pelo peso moral da agenda ecológica global que legitima a apropriação de terra e dos recursos por meio dos sumidores de carbono, culturas-plantações de combustíveis verdes ou reservas de compensação da biodiversidade, entre outras 'alternativas' para aplacar a crise ambiental. Os novos cercamentos justificam como contribuindo para o futuro do planeta por meio da conservação e da reparação podendo gerar lucros para firmas e elites, vencendo os interesses das populações locais. De fato, o que tem se observado nesse processo é como descrevem os autores:

[...] a cycle in which enclosures and dispossession lead to rural exodus - leaving lands 'empty' and so even easier to label as 'marginal' and under used, and open to further appropriation. This is of course a long-standing cycle in the history of rural land control (Peluso and Lund 2011), and a stock-in-trade of colonial intervention; but today's green markets threaten new impetus to such dynamics (FAIRHEAD et al., 2012, pg. 252).

Ainda há uma diversidade de situações que caracterizam o Green grabs que não é explicitamente reconhecido, pois não toma materialidade concreta no atual momento e ainda estão em processos de construção de acordos e as populações locais envolvidas só tomarão conhecimento muito tempo depois. Outros formatos assumem o que os autores chamam de "green debits" que só poderão ser reclamados na escala do tempo, constituindo assim um deslocamento tanto dos espaços quanto dos tempos. O que se percebe é que decisões são tomadas na escala global e as populações locais não são envolvidas, são sempre surpreendidas com decisões que afetam profundamente suas vidas e seus modos de relação com a natureza. Por outro lado, afirmam os autores:

At the same time, the pervasiveness of green market logics and valuations of nature in global discourses, media and consumer practices makes it all too easy to dismiss 
peasant resistance as individual, isolated opposition: not as valid social mobilization, but anachronistic holding-out against a common-sense green tide (FAIRHEAD et al., 2012, pg. 253).

As lutas agrárias, com foco na questão da terra e dos recursos, precisam ser revigoradas numa nova perspectiva, envolvendo outros atores sociais. Portanto, a luta pela distribuição de direitos e justiça deve continuar. Identificar os problemas e constituir a crítica é importante, mas não o suficiente para reversão do quadro, por isso, temos que fortalecer as experiências, dando visibilidade e organizando formas de apoiá-las, produzindo as ecologias do mundo real.

Como nos alenta Polanyi (2012): "Cada classe social, porém, mesmo inconscientemente, representa, numa ou noutra ocasião interesses mais amplos que os seus próprios" (pg. 149). Por certo, os camponeses, os povos indígenas e as comunidades tradicionais espraiados pelo território nacional, cumprem atualmente essa missão, disputando cada pedaço de chão e modos de se relacionar com a natureza e o projeto de soberania alimentar do MPA aí se insere, como um contramovimento (POLANYI, 2012).

A afirmação de Delgado (2017) sobre o novo papel que assume a reforma agrária no contexto atual em que as questões socioambientais tornam-se visíveis, concretas e de interesse e responsabilidade da sociedade em geral, não se restringindo apenas aqueles supostamente diretamente envolvidos, ou seja, os camponeses, povos indígenas e populações tradicionais. Portanto, nesse contexto, a justiça ambiental deve primariamente perseguir aquilo que o autor estabelece e que poderíamos chamar de proteção socioambiental, na medida em que considera as relações do homem com a natureza e com o próprio homem, assim:

Proteger a sociedade da desigualdade fundiária, proteger a natureza da dilapidação; proteger os grupos étnicos e culturais para as quais a terra é essencial. E ainda proteger as próprias relações de trabalho das tendências regressivas à escravidão são valores idealmente aceitos pela opinião pública (DELGADO, 2017, pg. 105).

No mesmo sentido, a soberania alimentar reivindica e pressupõe não apenas a função social da terra, mas sobretudo, a sua função política, entregue pelo Estado brasileiro às corporações internacionais do setor agroalimentar. Nas palavras de Martins (2000):

A questão agrária se redefine como forte componente da questão da soberania e não mais exclusiva ou principalmente como irracionalidade do processo de reprodução ampliada do capital. Redefine-se, pois, como questão política engendrada pela questão social, o que confirma a nossa tendência histórica de ter nos pobres e desvalidos os agentes sempre indiretos das ações demarcatórias da História, ainda que delas destinatários, mesmo que não reconheçam aí o seu 'projeto social explícito (pg. 123). 
Por fim, para finalizar o texto faço uso das palavras de Ribeiro (2017) que nos lembra que "Todas as mazelas e riquezas sociais estão espelhadas no espaço geográfico que é produto e palco das ações humanas" (pg. 153). Portanto, tanto a justiça espacial ${ }^{58}$ quanto à justiça ambiental $^{59}$, como descritas por Ribeiro (2017), no país resultam das escolhas políticas que a sociedade fez e permanece fazendo. Em que pese à justiça deveria ser o 'remédio' para aplacar as injustiças, aqui ela opera para desnudar as injustiças. De toda forma, para o caso brasileiro está claro após essa narrativa do legado e da perpetuação da concentração da terra, das riquezas e das oportunidades, bem como da produção das desigualdades que os camponeses estão expostos tanto a injustiça espacial quanto à injustiça socioambiental decorrentes da economia política contemporânea, mas sobretudo, dos caminhos que parte da elite brasileira e internacional e o Estado impôs e impõe, continuamente, a sociedade.

\footnotetext{
${ }^{58}$ Segundo Ribeiro (2017), justiça espacial “[...] expressa [...] como os agentes de produção do espaço geográfico o projetaram, de acordo com seus interesses, o que ajuda a desvendar a valorização do espaço, bem como, e principalmente, as desigualdades sociais inerentes ao processo de produção do espaço urbano capitalista”(pg. 157).

${ }^{59}$ Ribeiro (2017) assim define justiça socioambiental: "Justiça socioambiental pode ser entendida como a expressão da desigualdade social na apropriação do ambiente e de seus recursos. Ela é um instrumento analítico que remete à gênese da produção de mercadorias pelo sistema hegemônico e serve para conhecer o acesso desigual às vantagens e desvantagens que ele engendra" (pg. 161).
} 


\section{SÍNTESE DO CAPÍTULO}

Neste capítulo os conceitos de conflitos socioambientais e a injustiça ambiental foram utilizados para caracterizar a realidade vivenciada, historicamente, pelos camponeses desde a sua constituição como sujeitos no espaço do agrário nacional, bem como, no momento presente, na disputa de projeto socioambiental que ocupa esse cenário.

Foi discutido também como a agenda ambiental representada por novas demandas seja pela geração de energias limpas, sumidores de carbono, ecoturismo e/ou por um conjunto de tecnologias e inovações consideradas ambientalmente sustentáveis - estão impactando a disputa e o acesso aos recursos socioambientais. Tais realidades impõem antigas e novas restrições aos camponeses e seu projeto de soberania alimentar, na medida em que estão apropriadas pelo capital internacional e nacional, cujo objetivo exclusivo é o lucro, desprovido de responsabilidades e baseado na expropriação, produtora de desigualdades e injustiças socioambientais. 


\section{CAPÍTULO III - CONSTRUINDO A SOBERANIA ALIMENTAR E A SOBERANIA GENÉTICA: O PROJETO DE SEMENTES DO MOVIMENTO DOS PEQUENOS AGRICULTORES - MPA/BRASIL}

O objetivo deste capítulo é descrever a criação do Movimento de Pequenos Agricultores/MPA, bem como reconstituir o processo histórico da temática do resgate e conservação das sementes crioulas pelos camponeses e as transformações do tema no contexto político e institucional que o regulamenta. Para tanto, o texto conta com o aporte da documentação do próprio movimento, dos 'testimonios' dos camponeses no trabalho de campo e de revisão de literatura acerca do tema.

\subsection{O MOVIMENTO DOS PEQUENOS AGRICULTORES - MPA E A CONSTRUÇÃO DA SOBERANIA ALIMENTAR.}

A narrativa que passo a descrever e analisar neste capítulo é sobre o processo de resgate, conservação, multiplicação e distribuição de sementes que os camponeses organizados pelo MPA instituíram desde a década de 2000, como parte do plano camponês de Soberania Alimentar na perspectiva de massificar a produção de sementes crioulas e romper a perda crescente das sementes dos camponeses e, consequentemente o aumento da erosão genética dos recursos genéticos no país. Sem perder o fio que me conduziu até aqui, tentarei mostrar que esse processo exigiu uma ampla rede de atores e articulações, no passado e no presente, para a concretização do mesmo.

O campo brasileiro apresenta uma pluralidade de organizações sociais que abarcam desde pequenas organizações de âmbito locais como as associações e cooperativas - em suas diversas modalidades recreativas, de produção, de assentados, de crédito, entre outras; às de âmbito municipais, como os sindicatos de trabalhadores rurais e, mais recentemente, os sindicatos dos trabalhadores rurais na agricultura familiar; às de âmbito regionais e estaduais como as federações dos trabalhadores rurais ligadas à $\mathrm{CONTAG}^{60}$, bem como as federações ligadas a FETRAF ${ }^{61}$ e os movimentos de massa como o MST $^{62}$ e o MPA, ambos herdeiros das lutas históricas dos camponeses no Brasil.

\footnotetext{
${ }^{60}$ Confederação Nacional dos Trabalhadores na Agricultura (CONTAG) - http://www.contag.org.br.

55 Federação Nacional dos Trabalhadores e Trabalhadoras na Agricultura Familiar (FETRAF/BRASIL) http://www.fetraf.org.br.

${ }^{62}$ Movimento dos Trabalhadores Rurais Sem Terra (MST) - http://www.mst.org.br.
} 
Tais movimentos originaram-se em épocas e contextos históricos distintos e, portanto, são marcados na sua forma de organização e de luta por estes aspectos, mas sobretudo pelas condições materiais, subjetivas e ideológicas concretas que o forjaram. Apesar disso, a história tem mostrado que esses movimentos souberam renovar-se na sua pauta e conteúdo, conforme as mudanças operadas nas sociedades contemporâneas. Ainda assim, muitos desses movimentos não conseguiram dar respostas aos crescentes problemas sociais, econômicos e ambientais vivenciados pelos camponeses e novos movimentos sociais surgiram nas últimas décadas, tais como a FETRAF e o MPA. Aqui em particular, nos interessa compreender o MPA, sua formação, organização, concepção e projetos políticos em torno da Soberania Alimentar.

O Movimento dos Pequenos Agricultores - MPA está organizado atualmente em 17 estados da federação, agregando camponeses ${ }^{63}$ e suas organizações, tais como associações, cooperativas e sindicatos. O surgimento do movimento está intrinsecamente relacionado com as mobilizações que ocorreram durante a grande seca, no ano de 1996, no Rio Grande do Sul, que reuniu mais de 30.000 camponeses em acampamentos. Acumulou divergências de concepção, de organização e de luta com os movimentos sindicais de trabalhadores rurais e após a realização do $2^{\circ}$ Congresso dos Trabalhadores Rurais, ocorrido em Passo Fundo, no Rio Grande do Sul, nascia o MPA (CADONÁ, 2004). O MPA assim se define:

MPA é a afirmação do Campesinato. O Movimento dos Pequenos Agricultores é um Movimento Camponês, de caráter Nacional e Popular, de Massa, autônomo, de lutas permanentes, construído por grupos de famílias camponesas, que está comprometido com a conquista do Poder Popular e a construção de uma Nação Soberana. Seu principal objetivo é a Produção de comida Saudável e a Vida de qualidade para todas as famílias Camponesas e também para todo o povo brasileiro, garantindo assim, a soberania alimentar do país. Além disso, busca o resgate da identidade e da cultura camponesa, respeitando as diversidades regionais (MPA, 2009a, p. 20).

Apresenta uma estrutura organizacional horizontal, de baixo para cima, onde o núcleo local, considerado as famílias camponesas, dá origem ao primeiro nível de organização, seguida das coordenações - municipais, estaduais, regionais e nacional - e das direções (estadual e nacional). Há ainda instâncias de troca de experiências e espaços de deliberação, tais como a articulação nacional e os encontros estaduais e nacional. O MPA compõe a articulação camponesa internacional, Via Campesina e integra o escritório regional para a América Latina, no mandato atual (MPA, 2009a; CADONÁ, 2004).

\footnotetext{
${ }^{63}$ Como informa Cadoná (2004), os pequenos agricultores que compõem o MPA tem o tamanho de seus lotes menores que os assentados do MST, no Rio Grande do Sul, local onde ele desenvolveu seus estudos.
} 
No ano de 2004, o MPA organizou debates e discussões em torno do projeto político do movimento, o qual foi intitulado 'Plano Camponês'. É neste documento que consta a concepção, os objetivos, as estratégias e as tarefas do movimento para o fortalecimento do campesinato brasileiro; seu projeto de sociedade nacional, tem como base a soberania alimentar, energética, hídrica, genética e territorial.

O movimento parte da crítica ao modelo de produção tecnológica atual, concebido na chamada 'Revolução Verde' que tem no tripé insumos (sementes melhoradas - adubos químicos - agrotóxicos); a subordinação da agricultura à indústria; a substituição de trabalhadores por máquinas e o desenvolvimento de monocultivos para exportação sua fundamentação. Os resultados desse processo já estão largamente discutidos na literatura, como a destruição da diversidade dos sistemas de produção camponês, a contaminação das águas, dos solos e, sobretudo, o controle sobre os recursos naturais e os territórios dos camponeses, expulsos do campo e povoando as periferias pobres das cidades (empobrecidos e proletarizados). Assim descreve Shiva (2003) no livro que se tornou clássico na crítica a essa concepção de mundo: “[...] as monoculturas são uma fonte de escassez e de pobreza, tanto por destruir a diversidade e as alternativas quanto por destruir o controle descentralizado dos sistemas de produção e consumo" (SHIVA, 2003, p. 17).

O Plano Camponês parte dessa crítica, mas também elabora uma posição com relação ao sujeito que compõe o espaço rural hoje em contraposição ao conceito de agricultor familiar. Para o Movimento o conceito de agricultor familiar aproxima sujeitos e projetos do agronegócio nacional. Esse agricultor perderia sua característica fundante que é a produção para o consumo, em primeiro lugar, e o sobrante, para o mercado. O projeto do agricultor familiar assim como o do agronegócio seria abastecer o mercado. Segundo Cadoná (2004):

[...] diante dos agricultores, foram se configurando e se delimitando novos espaços políticos. De um lado, as organizações de agricultores familiares, voltados às políticas de integração ao capital, com afinidades e vínculos com a CONTAG, alguns setores da CUT- Rural, FETAG e, mais tarde, com a FETRAF-Sul. De outro lado, os movimentos sociais camponeses, coordenados pela Via Campesina, como o MST, MAB, CPT e o MPA, movimentos que passam a defender políticas de resistência e de confrontação na luta contra o capital (CADONÁ, 204, pg. 103).

Há um esforço teórico para conceituar camponês, campesinato e sistemas de produção camponês, na medida em que a este sujeito corresponderá um projeto específico, distante daqueles cujo o abastecimento do mercado esteja no seu horizonte primeiro. Assim, vejamos os princípios e os eixos que compõem este projeto, o Plano Camponês. 
Segundo MPA (2012b), o Plano tem na sua base conceitual os seguintes elementos: camponeses, sistemas de produção camponês, agroecologia e alimergia. Sinteticamente, camponeses é um modo de ser e de estar no mundo e seus sistemas de produção foram desenvolvidos ao longo de sua história com independência de insumos externos e respeito à natureza, 'autônomo e soberano'. A agroecologia é considerada a base científica e técnica que vai permitir desenvolver e alcançar a soberania alimentar. É ainda considerada um conceito prático e político, envolvendo várias dimensões: ecológica, social, econômica, política e cultural.

Por fim, o conceito de Alimergia expressa os resultados da sinergia entre as interações produzidas na interfase entre plantas, animais, sol, chuva e vento e os sistemas de produção, produzidas na relação dos camponeses com a natureza, gerando alimentos, energia líquida, elétrica e gás, permitindo aos camponeses, autonomia e soberania (MPA, 2012b).

O Movimento constrói estratégias para operacionalizar o Plano Camponês por meio dos denominados Eixos Estruturantes, assim definido:

Assim o eixo estruturante não é uma articulação de uma cadeia produtiva, mas sim um conjunto de estruturas de serviços voltados para as famílias camponesas com o intuito de que estas possam desenvolver ao máximo possível os sistemas camponeses de produção e uma produção amplamente diversificada para o abastecimento local, e quando a nível local já não absorve toda a produção, contribua para que seja comercializado na cidade mais próxima, desenvolvendo ao máximo possível a produção e consumo em circuitos curtos (MPA, 2012b, pg.20).

Este eixo estruturante está intrinsecamente ligado às famílias, comunidades e os territórios, onde as famílias camponesas estão inseridas, pois são elas as gestoras desse processo. O Plano compõe-se de seis eixos: produção, educação e formação, vida de qualidade, comunidade camponesa e soberania. É nesse eixo estruturante que se encontra o debate e a concepção de Soberania Alimentar, que para o movimento significa:

A soberania alimentar organiza a produção e o consumo de alimentos saudáveis de acordo com as necessidades das comunidades locais, dando prioridade para o consumo local e doméstico. Reconhece os direitos das mulheres camponesas e defende que todo o campesinato deve ter acesso à terra, água, sementes, recursos produtivos e serviços públicos adequados à sua realidade. Seus princípios rompem com a lógica neoliberal de tratar o alimento e a agricultura em si mesma como uma mercadoria, e colocam a alimentação como uma questão de estado e a autossuficiência alimentar considerada central para a soberania nacional (MPA, 2012b, p. 20).

Isso porque para o movimento a resistência ao sistema de dominação capitalista está fortemente ligada à construção de estratégias para a operacionalização da soberania alimentar assim concebida. Pois é a soberania alimentar estruturada a partir dos elementos acima 
elencados - camponeses, sistemas de produção camponês, agroecologia e alimergia - que fundamentará e garantirá a permanência dos camponeses no território. Esse último entendido como o espaço historicamente ocupado pelos camponeses. E a produção de alimentos necessariamente tem que ser produzida localmente porque está vinculada a um modo de vida, a cultura de um povo, respeitando o equilíbrio ambiental (MPA, 2012b).

Tal soberania liga-se ainda às demais soberanias, a saber; hídrica, energética, genética e do território. É ela que vai garantir a permanência do modo camponês de viver e de produzir. Interessam aqui, em particular, as estratégias em torno da construção do processo de soberania genética que envolve o resgate, manutenção e conservação, melhoramento, produção e distribuição de sementes crioulas. Embora, essa estratégia esteja relacionada à soberania hídrica e territorial, pois sem água e terra para produzir não há como garantir soberania genética e alimentar. Terra e água são as condições primevas.

Desde 1996, o MPA desenvolve uma série de atividades em torno dessa temática que envolve o nível das famílias camponesas, das comunidades e o nível dos territórios, reunidos, no último período, no Plano Nacional de Sementes. Esse Plano avança no sentido de massificar o acesso ao acervo de sementes crioulas disponíveis, tanto pelas famílias camponesas, quanto pelas comunidades.

As famílias camponesas guardiães de suas sementes continua a ser o princípio dessa estratégia, mas ao dinamizar esse processo, objetivando constituir um polo de resistência ao avanço dos transgênicos nos sistemas de produção dos camponeses, o MPA inova com a instalação das UBS - Unidades de Beneficiamento de Sementes Crioulas. Tal estratégia dialoga com a campanha internacional da Via Campesina - As Sementes são Patrimônio dos Povos a Serviço da Humanidade. Assim, o MPA constrói uma experiência singular, tornandose referência para fazer frente à perda crescente da biodiversidade e, sobretudo, da memória biocultural do campesinato nacional.

Considerada hoje a maior Planta de Produção de Sementes crioulas em mãos dos camponeses na América Latina, a experiência com a implantação da UBS teve início pelo estado de Santa Catarina, no município de São Miguel do Oeste, administrada pela cooperativa Oestebio (COOPERATIVA, 2014).

Esse é um amplo e complexo processo de disputa, que envolve aspectos políticos e técnicos, perpassando a sociedade civil e as políticas de governo e, que certamente vem produzindo um rico processo de aprendizagens para o movimento e camponeses nele envolvido. 


\subsection{O TERRITÓRIO - PAISAGEM CAMPONESA NO OESTE DE SANTA CATARINA}

Figura 1 - Fotografia da propriedade de uma camponesa que participa da rede de multiplicadores, no município de Anchieta-SC-Brasil. Registro realizado pela autora durante o trabalho de campo em maio de 2016.

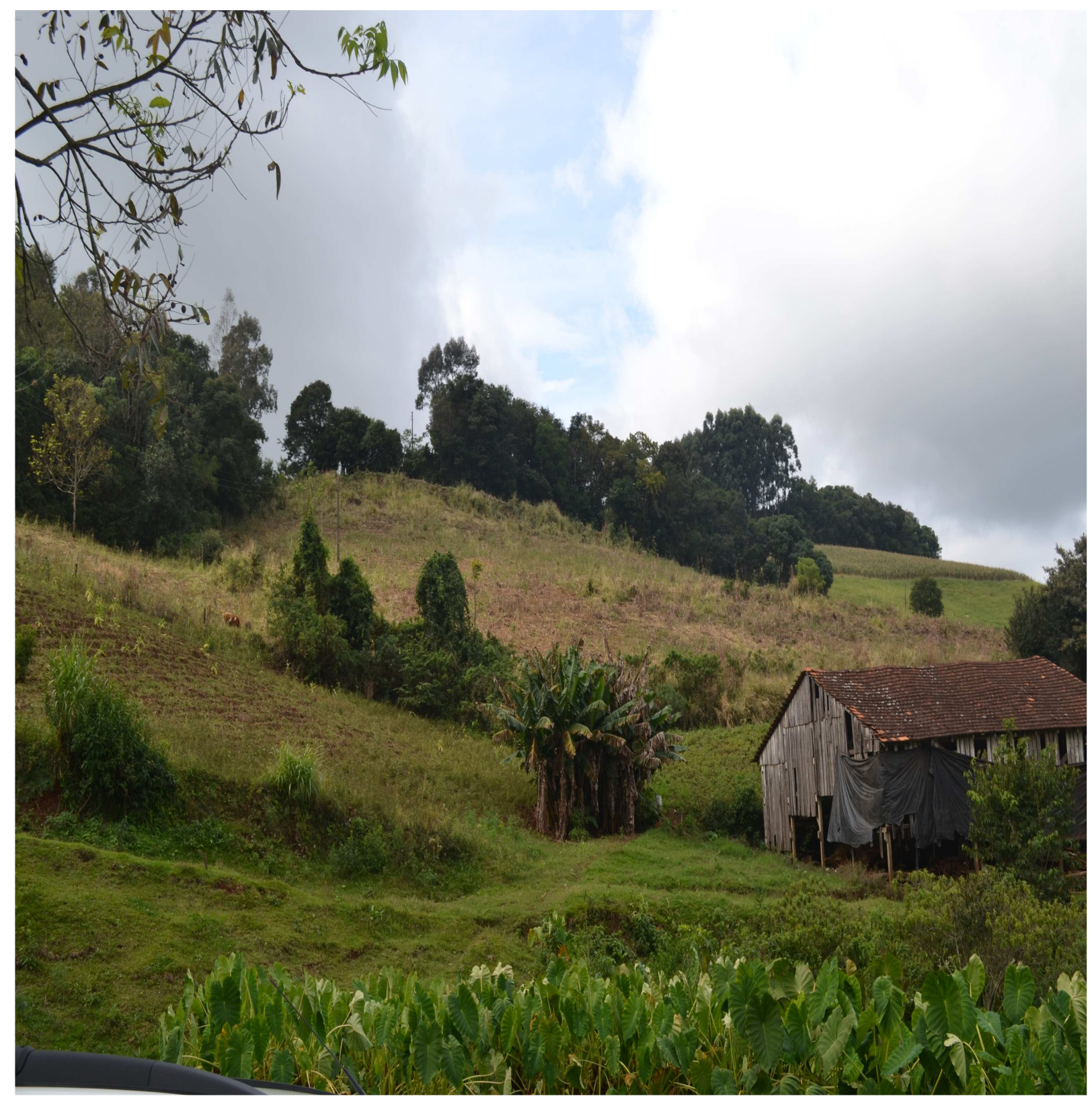

O estado de Santa Catarina é o que detém, entre os três estados da região sul do país, o maior número de propriedades da agricultura familiar e camponesa com um percentual de $87 \%$ dos estabelecimentos agropecuários desse estado, ocupando uma área de 43,79\% da área total dos estabelecimentos (STOFFEL, 2012). Vale salientar que Santa Catarina está localizado no centro geográfico de maior desempenho econômico do país, sul e sudeste. 
Participa ativamente na composição dos produtos da pauta de exportação do setor agropecuário e abastece também com vários produtos o mercado interno local e nacional.

São Miguel do Oeste, um dos 295 municípios do estado, está localizado na mesorregião denominada Oeste Catarinense, uma das regiões de maior concentração da agricultura familiar do estado, desenvolvendo uma agricultura e pecuária bastante diversificada (BUAINAIN et al., 2012). Esse município foi colonizado por migrantes provenientes do estado do Rio Grande do Sul, representando uma das últimas fronteiras agrícolas deste estado, conhecida como fronteira Oeste, na década de 1920.

Localizado no bioma Mata Atlântica, possui atualmente 36.306 habitantes em uma área de $234.055 \mathrm{~km}^{2}$. Como a grande maioria dos municípios desse estado, possui IDH (Índice de Desenvolvimento Humano) de 0,801 (IBGE, 2010). Aqui, desenvolve-se uma agricultura diversificada, com presença marcante da agroindústria de aves e suínos e suas respectivas indústrias de produtos alimentícios, tais como a Aurora Alimentos, cuja matriz encontra-se na cidade de Chapecó, a capital regional do Oeste catarinense.

Possui também uma bacia leiteira significativa, além da indústria do fumo. Essas são atividades em que parcela significativa desses camponeses está inserida como integrados. O cultivo do milho representa uma das principais lavouras, além do feijão e outros cultivos, como, por exemplo, aveia, trigo, ervilha, entre outras culturas destinadas ao consumo das famílias. A usina de beneficiamento de sementes do movimento foi instalada nesse município, mas a rede de multiplicadores e de guardiões está distribuída para além desse município, como será demonstrado. 
Figura 2 - Mapa das mesorregiões do Estado de Santa Catarina

Fonte: https://commons.wikimedia.org.

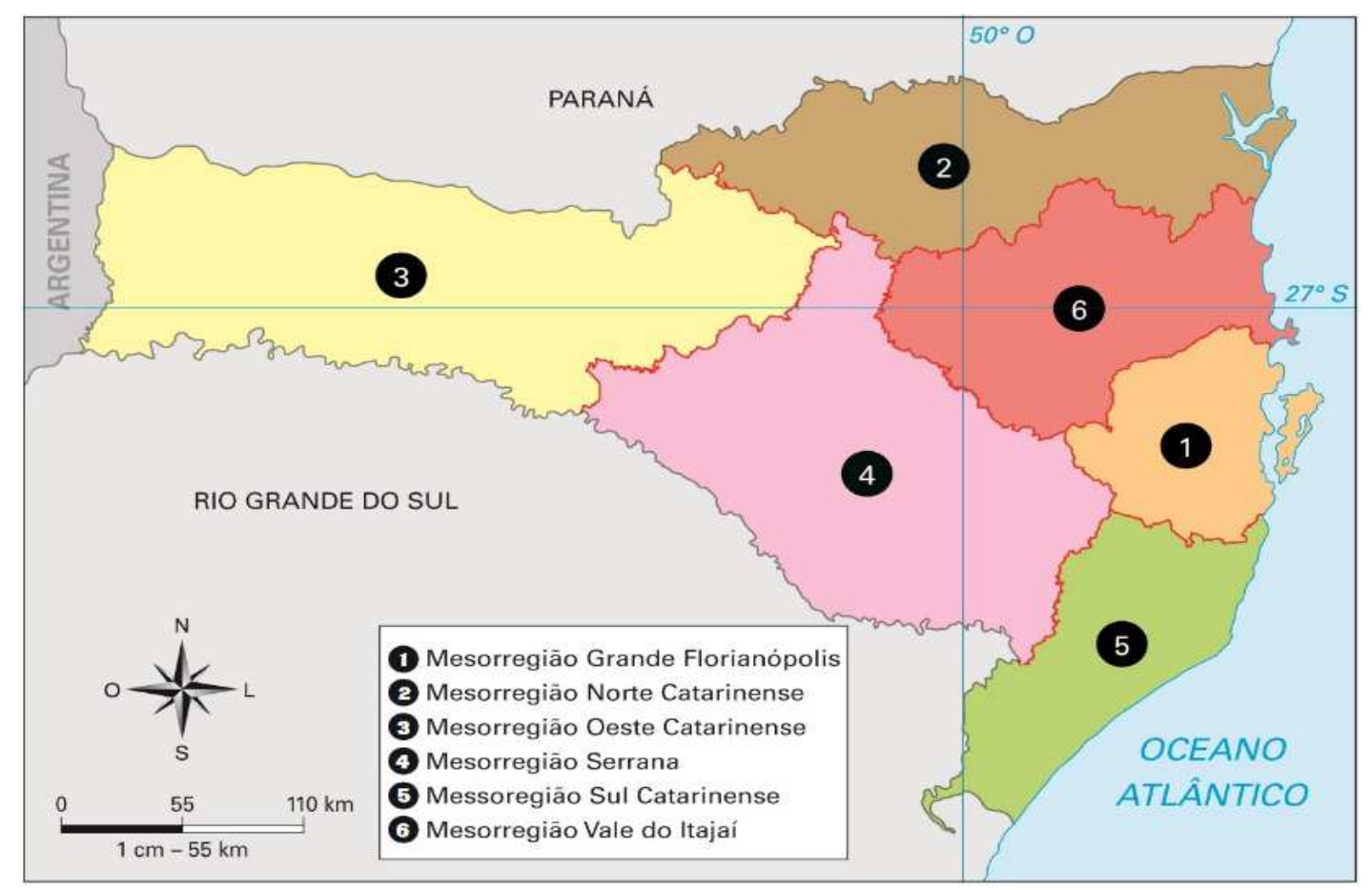

A mesorregião do Oeste Catarinense concentra a maior parte da população rural de Santa Catarina (34\%), que pertence à agricultura familiar e camponesa, como também a produção dos principais produtos agrícolas do estado, tais como carne bovina $(49,4 \%)$, produção de frangos $(77,9 \%)$, produção de suínos $(77,2 \%)$, bem como a produção leitera, o fumo e as culturas do milho e do feijão. Essa é uma região onde houve forte incentivo para a agricultura familiar e camponesa se integrarem a agroindústria de suínos e aves por meio do "Pronafinho" com o uso do aval solidário. Assim muitos desses camponeses plantavam milho e fumo para abastecerem a agroindústria.

Vale salientar que no ranking das cadeias produtivas do estado, esses produtos estão em ordem de grandeza nas seguintes posições: $1^{\circ}$ carne de frango; $2^{\circ}$ carne suína; $3^{\circ}$ leite; $4^{\circ}$ soja; $5^{\circ}$ fumo; $6^{\circ}$ milho e $9^{\circ}$ ovos de galinha (EPAGRI, 2017). Por isso, há de se concordar com Mattei (2016) sobre o papel prepoderante da presença da agricultura familiar e camponesa na produção dessa performance, ainda que permaneça o quadro de desigualdade na distribuição do recurso terra.

Quase 90\% (88,3\%) das propriedades rurais do estado de Santa Catarina possuem até 50 hectares e ocupa $40 \%$ da área do seu território, sendo que há o predomínio de minifúndios com propriedades que variam entre 1 a 10 hectares, distribuídos em 5,5\% da área total do 
Estado. Considerando que o módulo rural - que deve garantir a sobrevivência de uma família na terra - varia conforme as condições ambientais e a geografia do município e que o território do estado possui uma topografia bastante acidentada, há diversas e diferentes situações neste universo. Não é por acaso que Marcondes (2016) leva em consideração essa característica, dentre outras, quando avalia o baixo interesse do capital na aquisição dessas terras para implantação de grandes lavouras e a contínua resistência camponesa em permanecer na agricultura, mesmo com parcos recursos de terra disponíveis.

Veja abaixo a distribuição do recurso terra (Tabela 1) conforme a classificação do IBGE nas categorias minifúndios, pequenas propriedades, médias propriedades e grandes propriedades nos municípios onde estão localizados os camponeses que participam da rede de multiplicadores da Oestebio, são noventa e três municípios no Estado de Santa Catarina, um no Paraná e dois no estado do Rio Grande do Sul. São dados atualizados, extraídos do Cadastro Ambiental Rural e com valores próximos com as informações coletadas pelo IBGE e reunidas pela EPAGRI (2017).

Tabela 1 - Distribuição de terra nos municípios da rede de multiplicadores do projeto de sementes do MPA, no estado de Santa Catarina, Brasil.

Fonte: IBGE, 2006; CAR, 2017. Elaborado por Sato, 2017.

Nota geral - Foram utilizadas as seguintes abreviações: Minif.= minifúndios; Peq. Prop.= pequena propriedade; Méd. Prop.= média propriedade; G.des Prop.= grande propriedade. 


\begin{tabular}{|c|c|c|c|c|c|c|c|c|c|c|}
\hline \multirow{2}{*}{ Município } & \multicolumn{5}{|c|}{$\begin{array}{l}\text { Número de propriedades (classificado a } \\
\text { partir dos módulos fiscais) }\end{array}$} & \multicolumn{5}{|c|}{ Percentual do total das propriedades } \\
\hline & Minif. & $\begin{array}{l}\text { Peq. } \\
\text { Prop. }\end{array}$ & $\begin{array}{l}\text { Méd. } \\
\text { Prop. }\end{array}$ & $\begin{array}{l}\text { G. } \\
\text { Prop. }\end{array}$ & Total & Minif. & $\begin{array}{l}\text { Peq. } \\
\text { Prop. }\end{array}$ & $\begin{array}{l}\text { Méd. } \\
\text { Prop. }\end{array}$ & $\begin{array}{l}\text { G. } \\
\text { Prop. }\end{array}$ & Total \\
\hline $\begin{array}{l}\text { Abelardo } \\
\text { Luz }\end{array}$ & 588 & 293 & 86 & 27 & 994 & $59 \%$ & $29 \%$ & $9 \%$ & $3 \%$ & $100 \%$ \\
\hline Água Doce & 445 & 326 & 102 & 91 & 964 & $46 \%$ & $34 \%$ & $11 \%$ & $9 \%$ & $100 \%$ \\
\hline $\begin{array}{l}\text { Águas de } \\
\text { Chapecó }\end{array}$ & 3 & 472 & 280 & 32 & 787 & $0 \%$ & $60 \%$ & $36 \%$ & $4 \%$ & $100 \%$ \\
\hline Anchieta & 14 & 569 & 546 & 169 & 1298 & $1 \%$ & $44 \%$ & $42 \%$ & $13 \%$ & $100 \%$ \\
\hline Bandeirante & 635 & 106 & 6 & 0 & 747 & $85 \%$ & $14 \%$ & $1 \%$ & $0 \%$ & $100 \%$ \\
\hline $\begin{array}{l}\text { Barra } \\
\text { Bonita }\end{array}$ & 496 & 84 & 1 & 0 & 581 & $85 \%$ & $14 \%$ & $0 \%$ & $0 \%$ & $100 \%$ \\
\hline $\begin{array}{l}\text { Bela Vista } \\
\text { do Toldo }\end{array}$ & 725 & 181 & 15 & 9 & 930 & $78 \%$ & $19 \%$ & $2 \%$ & $1 \%$ & $100 \%$ \\
\hline Belmonte & 489 & 119 & 0 & 0 & 608 & $80 \%$ & $20 \%$ & $0 \%$ & $0 \%$ & $100 \%$ \\
\hline $\begin{array}{l}\text { Bom Jesus } \\
\text { do Oeste }\end{array}$ & 531 & 19 & 0 & 0 & 550 & $97 \%$ & $3 \%$ & $0 \%$ & $0 \%$ & $100 \%$ \\
\hline Brunópolis & 407 & 188 & 42 & 8 & 645 & $63 \%$ & $29 \%$ & $7 \%$ & $1 \%$ & $100 \%$ \\
\hline Caibí & 891 & 158 & 3 & 0 & 1052 & $85 \%$ & $15 \%$ & $0 \%$ & $0 \%$ & $100 \%$ \\
\hline Campo Erê & 590 & 213 & 48 & 10 & 861 & $69 \%$ & $25 \%$ & $6 \%$ & $1 \%$ & $100 \%$ \\
\hline $\begin{array}{c}\text { Campos } \\
\text { Novos }\end{array}$ & 1456 & 621 & 167 & 26 & 2270 & $64 \%$ & $27 \%$ & $7 \%$ & $1 \%$ & $100 \%$ \\
\hline Canoinhas & 1591 & 404 & 73 & 22 & 2090 & $76 \%$ & $19 \%$ & $3 \%$ & $1 \%$ & $100 \%$ \\
\hline $\begin{array}{l}\text { Caxambu } \\
\text { do Sul }\end{array}$ & 570 & 92 & 0 & 1 & 663 & $86 \%$ & $14 \%$ & $0 \%$ & $0 \%$ & $100 \%$ \\
\hline Chapecó & 1451 & 285 & 35 & 3 & 1774 & $82 \%$ & $16 \%$ & $2 \%$ & $0 \%$ & $100 \%$ \\
\hline $\begin{array}{l}\text { Coronel } \\
\text { Martins }\end{array}$ & 264 & 73 & 0 & 0 & 337 & $78 \%$ & $22 \%$ & $0 \%$ & $0 \%$ & $100 \%$ \\
\hline $\begin{array}{l}\text { Correia } \\
\text { Pinto }\end{array}$ & 329 & 194 & 61 & 18 & 602 & $55 \%$ & $32 \%$ & $10 \%$ & $3 \%$ & $100 \%$ \\
\hline Cunha Porã & 1453 & 187 & 1 & 1 & 1642 & $88 \%$ & $11 \%$ & $0 \%$ & $0 \%$ & $100 \%$ \\
\hline Cunhataí & 392 & 35 & 0 & 0 & 427 & $92 \%$ & $8 \%$ & $0 \%$ & $0 \%$ & $100 \%$ \\
\hline Curitibanos & 633 & 262 & 105 & 17 & 1017 & $62 \%$ & $26 \%$ & $10 \%$ & $2 \%$ & $100 \%$ \\
\hline Descanso & 1464 & 329 & 6 & 0 & 1799 & $81 \%$ & $18 \%$ & $0 \%$ & $0 \%$ & $100 \%$ \\
\hline $\begin{array}{l}\text { Dionísio } \\
\text { Cerqueira }\end{array}$ & 1263 & 249 & 33 & 1 & 1546 & $82 \%$ & $16 \%$ & $2 \%$ & $0 \%$ & $100 \%$ \\
\hline $\begin{array}{c}\text { Faxinal dos } \\
\text { Guedes }\end{array}$ & 352 & 229 & 16 & 3 & 600 & $59 \%$ & $38 \%$ & $3 \%$ & $1 \%$ & $100 \%$ \\
\hline $\begin{array}{l}\text { Flor do } \\
\text { Sertão }\end{array}$ & 489 & 47 & 0 & 0 & 536 & $91 \%$ & $9 \%$ & $0 \%$ & $0 \%$ & $100 \%$ \\
\hline $\begin{array}{l}\text { Formosa do } \\
\quad \text { Sul }\end{array}$ & 453 & 149 & 1 & 0 & 603 & $75 \%$ & $25 \%$ & $0 \%$ & $0 \%$ & $100 \%$ \\
\hline Fraiburgo & 406 & 283 & 44 & 16 & 749 & $54 \%$ & $38 \%$ & $6 \%$ & $2 \%$ & $100 \%$ \\
\hline $\begin{array}{c}\text { Frei } \\
\text { Rogério }\end{array}$ & 270 & 78 & 7 & 1 & 356 & $76 \%$ & $22 \%$ & $2 \%$ & $0 \%$ & $100 \%$ \\
\hline Galvão & 284 & 88 & 4 & 1 & 377 & $75 \%$ & $23 \%$ & $1 \%$ & $0 \%$ & $100 \%$ \\
\hline Guaraciaba & 1644 & 347 & 7 & 0 & 1998 & $82 \%$ & $17 \%$ & $0 \%$ & $0 \%$ & $100 \%$ \\
\hline $\begin{array}{l}\text { Guarujá do } \\
\text { Sul }\end{array}$ & 513 & 85 & 2 & 0 & 600 & $86 \%$ & $14 \%$ & $0 \%$ & $0 \%$ & $100 \%$ \\
\hline
\end{tabular}

Continua 
Continuação

\begin{tabular}{|c|c|c|c|c|c|c|c|c|c|c|}
\hline \multirow{2}{*}{ Município } & \multicolumn{5}{|c|}{$\begin{array}{c}\text { Número de propriedades (classificado a } \\
\text { partir dos módulos fiscais) }\end{array}$} & \multicolumn{5}{|c|}{ Percentual do total das propriedades } \\
\hline & Minif. & $\begin{array}{l}\text { Peq. } \\
\text { Prop. }\end{array}$ & $\begin{array}{l}\text { Méd. } \\
\text { Prop. }\end{array}$ & $\begin{array}{l}\text { G. }{ }^{\text {des }} \\
\text { Prop }\end{array}$ & Total & Minif. & $\begin{array}{l}\text { Peq. } \\
\text { Prop. }\end{array}$ & $\begin{array}{l}\text { Méd. } \\
\text { Prop. }\end{array}$ & $\begin{array}{l}\text { G. }{ }^{\text {des }} \\
\text { Prop }\end{array}$ & Total \\
\hline Guatambu & 546 & 167 & 15 & 1 & 729 & $75 \%$ & $23 \%$ & $2 \%$ & $0 \%$ & $100 \%$ \\
\hline $\begin{array}{l}\text { Iporã do } \\
\text { Oeste }\end{array}$ & 1030 & 181 & 3 & 1 & 1215 & $85 \%$ & $15 \%$ & $0 \%$ & $0 \%$ & $100 \%$ \\
\hline Iraceminha & 1106 & 237 & 1 & 0 & 1344 & $82 \%$ & $18 \%$ & $0 \%$ & $0 \%$ & $100 \%$ \\
\hline Irati & 362 & 119 & 2 & 0 & 483 & $75 \%$ & $25 \%$ & $0 \%$ & $0 \%$ & $100 \%$ \\
\hline Irineópolis & 583 & 322 & 29 & 3 & 937 & $62 \%$ & $34 \%$ & $3 \%$ & $0 \%$ & $100 \%$ \\
\hline Itaiópolis & 1081 & 716 & 79 & 10 & 1886 & $57 \%$ & $38 \%$ & $4 \%$ & $1 \%$ & $100 \%$ \\
\hline Itapiranga & 1664 & 212 & 1 & 0 & 1877 & $89 \%$ & $11 \%$ & $0 \%$ & $0 \%$ & $100 \%$ \\
\hline Jardinópolis & 291 & 97 & 0 & 0 & 388 & $75 \%$ & $25 \%$ & $0 \%$ & $0 \%$ & $100 \%$ \\
\hline $\begin{array}{l}\text { Lajeado } \\
\text { Grande }\end{array}$ & 297 & 56 & 1 & 0 & 354 & $84 \%$ & $16 \%$ & $0 \%$ & $0 \%$ & $100 \%$ \\
\hline $\begin{array}{l}\text { Lebon } \\
\text { Regis }\end{array}$ & 189 & 201 & 112 & 33 & 535 & $35 \%$ & $38 \%$ & $21 \%$ & $6 \%$ & $100 \%$ \\
\hline Mafra & 1672 & 579 & 98 & 27 & 2376 & $70 \%$ & $24 \%$ & $4 \%$ & $1 \%$ & $100 \%$ \\
\hline $\begin{array}{l}\text { Major } \\
\text { Vieira }\end{array}$ & 1000 & 284 & 22 & 4 & 1310 & $76 \%$ & $22 \%$ & $2 \%$ & $0 \%$ & $100 \%$ \\
\hline Maravilha & 1240 & 107 & 0 & 0 & 1347 & $92 \%$ & $8 \%$ & $0 \%$ & $0 \%$ & $100 \%$ \\
\hline Modelo & 524 & 72 & 2 & 0 & 598 & $88 \%$ & $12 \%$ & $0 \%$ & $0 \%$ & $100 \%$ \\
\hline Mondaí & 1232 & 164 & 1 & 0 & 1397 & $88 \%$ & $12 \%$ & $0 \%$ & $0 \%$ & $100 \%$ \\
\hline $\begin{array}{l}\text { Monte } \\
\text { Carlo }\end{array}$ & 173 & 50 & 7 & 7 & 237 & $73 \%$ & $21 \%$ & $3 \%$ & $3 \%$ & $100 \%$ \\
\hline $\begin{array}{c}\text { Monte } \\
\text { Castelo }\end{array}$ & 296 & 173 & 42 & 13 & 524 & $56 \%$ & $33 \%$ & $8 \%$ & $2 \%$ & $100 \%$ \\
\hline $\begin{array}{l}\text { Nova } \\
\text { Erechim }\end{array}$ & 268 & 45 & 0 & 0 & 313 & $86 \%$ & $14 \%$ & $0 \%$ & $0 \%$ & $100 \%$ \\
\hline $\begin{array}{c}\text { Nova } \\
\text { Itaberaba }\end{array}$ & 516 & 115 & 0 & 0 & 631 & $82 \%$ & $18 \%$ & $0 \%$ & $0 \%$ & $100 \%$ \\
\hline $\begin{array}{l}\text { Novo } \\
\text { Horizonte }\end{array}$ & 397 & 195 & 1 & 0 & 593 & $67 \%$ & $33 \%$ & $0 \%$ & $0 \%$ & $100 \%$ \\
\hline Palma Sola & 668 & 186 & 4 & 3 & 861 & $78 \%$ & $22 \%$ & $0 \%$ & $0 \%$ & $100 \%$ \\
\hline Palmitos & 1236 & 176 & 0 & 1 & 1413 & $87 \%$ & $12 \%$ & $0 \%$ & $0 \%$ & $100 \%$ \\
\hline Papanduvas & 748 & 295 & 56 & 10 & 1109 & $67 \%$ & $27 \%$ & $5 \%$ & $1 \%$ & $100 \%$ \\
\hline Paraíso & 808 & 139 & 3 & 0 & 950 & $85 \%$ & $15 \%$ & $0 \%$ & $0 \%$ & $100 \%$ \\
\hline $\begin{array}{c}\text { Passos } \\
\text { Maia }\end{array}$ & 170 & 126 & 26 & 14 & 336 & $51 \%$ & $38 \%$ & $8 \%$ & $4 \%$ & $100 \%$ \\
\hline Pinhalzinho & 617 & 95 & 0 & 0 & 712 & $87 \%$ & $13 \%$ & $0 \%$ & $0 \%$ & $100 \%$ \\
\hline $\begin{array}{l}\text { Pinheiro } \\
\text { Preto }\end{array}$ & 185 & 76 & 0 & 0 & 261 & $71 \%$ & $29 \%$ & $0 \%$ & $0 \%$ & $100 \%$ \\
\hline $\begin{array}{l}\text { Planalto } \\
\text { Alegre }\end{array}$ & 316 & 65 & 0 & 0 & 381 & $83 \%$ & $17 \%$ & $0 \%$ & $0 \%$ & $100 \%$ \\
\hline Ponte Alta & 118 & 92 & 46 & 17 & 273 & $43 \%$ & $34 \%$ & $17 \%$ & $6 \%$ & $100 \%$ \\
\hline $\begin{array}{l}\text { Ponte } \\
\text { Serrada }\end{array}$ & 195 & 159 & 26 & 17 & 397 & $49 \%$ & $40 \%$ & $7 \%$ & $4 \%$ & $100 \%$ \\
\hline Princesa & 560 & 53 & 1 & 0 & 614 & $91 \%$ & $9 \%$ & $0 \%$ & $0 \%$ & $100 \%$ \\
\hline $\begin{array}{l}\text { Rio das } \\
\text { Antas }\end{array}$ & 326 & 265 & 14 & 4 & 609 & $54 \%$ & $44 \%$ & $2 \%$ & $1 \%$ & $100 \%$ \\
\hline
\end{tabular}

Continua 
Continuação

\begin{tabular}{|c|c|c|c|c|c|c|c|c|c|c|}
\hline \multirow[b]{2}{*}{ Município } & \multicolumn{5}{|c|}{$\begin{array}{c}\text { Número de propriedades (classificado a } \\
\text { partir dos módulos fiscais) }\end{array}$} & \multicolumn{5}{|c|}{ Percentual do total das propriedades } \\
\hline & Minif. & $\begin{array}{l}\text { Peq. } \\
\text { Prop. }\end{array}$ & $\begin{array}{l}\text { Méd. } \\
\text { Prop. }\end{array}$ & $\begin{array}{l}\text { G. }{ }^{\text {des }} \\
\text { Prop. }\end{array}$ & Total & Minif. & $\begin{array}{l}\text { Peq. } \\
\text { Prop. }\end{array}$ & $\begin{array}{l}\text { Méd. } \\
\text { Prop. }\end{array}$ & $\begin{array}{l}\text { G. } \\
\text { Prop. }\end{array}$ & Total \\
\hline Rio Negrinho & 315 & 240 & 73 & 33 & 661 & $48 \%$ & $36 \%$ & $11 \%$ & $5 \%$ & $100 \%$ \\
\hline Riqueza & 1068 & 156 & 2 & 0 & 1226 & $87 \%$ & $13 \%$ & $0 \%$ & $0 \%$ & $100 \%$ \\
\hline Romelândia & 893 & 316 & 12 & 0 & 1221 & $73 \%$ & $26 \%$ & $1 \%$ & $0 \%$ & $100 \%$ \\
\hline Saltinho & 674 & 214 & 12 & 1 & 901 & $75 \%$ & $24 \%$ & $1 \%$ & $0 \%$ & $100 \%$ \\
\hline Santa Cecília & 90 & 90 & 66 & 35 & 281 & $32 \%$ & $32 \%$ & $23 \%$ & $12 \%$ & $100 \%$ \\
\hline Santa Helena & 377 & 76 & 0 & 0 & 453 & $83 \%$ & $17 \%$ & $0 \%$ & $0 \%$ & $100 \%$ \\
\hline $\begin{array}{c}\text { Santa } \\
\text { Terezinha }\end{array}$ & 683 & 591 & 34 & 9 & 1317 & $52 \%$ & $45 \%$ & $3 \%$ & $1 \%$ & $100 \%$ \\
\hline $\begin{array}{c}\text { Santa } \\
\text { Terezinha do } \\
\text { Progresso }\end{array}$ & 593 & 119 & 6 & 0 & 718 & $83 \%$ & $17 \%$ & $1 \%$ & $0 \%$ & $100 \%$ \\
\hline $\begin{array}{l}\text { São } \\
\text { Bernardino }\end{array}$ & 360 & 100 & 12 & 1 & 473 & $76 \%$ & $21 \%$ & $3 \%$ & $0 \%$ & $100 \%$ \\
\hline São Carlos & 1100 & 127 & 0 & 0 & 1227 & $90 \%$ & $10 \%$ & $0 \%$ & $0 \%$ & $100 \%$ \\
\hline $\begin{array}{l}\text { São Cristovão } \\
\text { do Sul }\end{array}$ & 126 & 84 & 28 & 15 & 253 & $50 \%$ & $33 \%$ & $11 \%$ & $6 \%$ & $100 \%$ \\
\hline $\begin{array}{l}\text { São } \\
\text { Domingos }\end{array}$ & 816 & 302 & 8 & 0 & 1126 & $72 \%$ & $27 \%$ & $1 \%$ & $0 \%$ & $100 \%$ \\
\hline $\begin{array}{l}\text { São João do } \\
\text { Oeste }\end{array}$ & 909 & 129 & 0 & 0 & 1038 & $88 \%$ & $12 \%$ & $0 \%$ & $0 \%$ & $100 \%$ \\
\hline $\begin{array}{l}\text { São José do } \\
\text { Cedro }\end{array}$ & 1618 & 196 & 1 & 0 & 1815 & $89 \%$ & $11 \%$ & $0 \%$ & $0 \%$ & $100 \%$ \\
\hline $\begin{array}{l}\text { São José do } \\
\text { Cerrito }\end{array}$ & 778 & 346 & 52 & 7 & 1183 & $66 \%$ & $29 \%$ & $4 \%$ & $1 \%$ & $100 \%$ \\
\hline $\begin{array}{l}\text { São Lourenço } \\
\text { do Oeste }\end{array}$ & 1151 & 393 & 11 & 0 & 1555 & $74 \%$ & $25 \%$ & $1 \%$ & $0 \%$ & $100 \%$ \\
\hline $\begin{array}{l}\text { São Miguel } \\
\text { da Boa Vista }\end{array}$ & 414 & 63 & 0 & 0 & 477 & $87 \%$ & $13 \%$ & $0 \%$ & $0 \%$ & $100 \%$ \\
\hline $\begin{array}{l}\text { São Miguel } \\
\text { do Oeste }\end{array}$ & 1268 & 160 & 7 & 0 & 1435 & $88 \%$ & $11 \%$ & $0 \%$ & $0 \%$ & $100 \%$ \\
\hline Saudades & 1250 & 151 & 1 & 0 & 1402 & $89 \%$ & $11 \%$ & $0 \%$ & $0 \%$ & $100 \%$ \\
\hline Serra Alta & 375 & 54 & 0 & 0 & 429 & $87 \%$ & $13 \%$ & $0 \%$ & $0 \%$ & $100 \%$ \\
\hline Sul Brasil & 529 & 141 & 1 & 0 & 671 & $79 \%$ & $21 \%$ & $0 \%$ & $0 \%$ & $100 \%$ \\
\hline Tangará & 607 & 459 & 22 & 5 & 1093 & $56 \%$ & $42 \%$ & $2 \%$ & $0 \%$ & $100 \%$ \\
\hline Tigrinhos & 525 & 26 & 3 & 2 & 556 & $94 \%$ & $5 \%$ & $1 \%$ & $0 \%$ & $100 \%$ \\
\hline $\begin{array}{l}\text { Timbó } \\
\text { Grande }\end{array}$ & 224 & 154 & 36 & 5 & 419 & $53 \%$ & $37 \%$ & $9 \%$ & $1 \%$ & $100 \%$ \\
\hline Tunápolis & 725 & 97 & 0 & 0 & 822 & $88 \%$ & $12 \%$ & $0 \%$ & $0 \%$ & $100 \%$ \\
\hline $\begin{array}{l}\text { União do } \\
\text { Oeste }\end{array}$ & 413 & 64 & 0 & 0 & 477 & $87 \%$ & $13 \%$ & $0 \%$ & $0 \%$ & $100 \%$ \\
\hline Vargem & 375 & 99 & 15 & 2 & 491 & $76 \%$ & $20 \%$ & $3 \%$ & $0 \%$ & $100 \%$ \\
\hline Videira & 671 & 444 & 12 & 0 & 1127 & $60 \%$ & $39 \%$ & $1 \%$ & $0 \%$ & $100 \%$ \\
\hline Xaxim & 946 & 240 & 5 & 0 & 1191 & $79 \%$ & $20 \%$ & $0 \%$ & $0 \%$ & $100 \%$ \\
\hline
\end{tabular}

Conclusão. 
Há nessa região agricultores que migraram do estado do Rio Grande do Sul em busca de terra, ocupando minifúndios, mas também há aqueles camponeses que possuíam mais recursos e adquiriram propriedades maiores, que não alcançam mais que 50 hectares. Onde a paisagem é plana, as propriedades tendem a ser maiores, como por exemplo, no município de Campo Erê, no qual se desenvolve outro tipo de agricultura. Naquelas em que predominam áreas mais acidentadas as propriedades são menores, geralmente entre 3 a 5 hectares.

Ainda que, ocupando áreas pequenas e integradas, os camponeses mantêm em suas propriedades um roçado policultivado com culturas como cana de açúcar, milho, feijão, leguminosas, entre outras, que compõem a cesta alimentar da família. Também há a presença de pequenos animais e predomina o gado de leite para abastecimento da agroindústria do leite que nos últimos anos têm apresentado um crescimento significativo, ocupando a $5^{\mathrm{a}}$ posição no ranking da bacia leiteira nacional (EPAGRI, 2017).

Por ser uma região próxima aos cultivos de grãos para exportação como milho e soja tanto pelos estados vizinhos Paraná e Rio Grande do Sul quanto pelas regiões de cultivo do próprio estado - os agricultores estão cada dia mais preocupados com o avanço dos cultivos transgênicos na região e a contaminação de suas lavouras. Além disso, a inserção desses agricultores nas indústrias de integração, em especial na de fumo tem deixado pouco espaço de área e de tempo - para os cultivos tradicionais como, por exemplo, o milho que já vem sendo exportado de outros estados para abastecer as agroindústrias locais. 


\subsection{A EXPERIÊNCIA DO MPA NO SUL DO PAÍS - SANTA CATARINA}

Figura 3 - Registro realizado por ocasião de pesquisa de campo pela autora, no paiol de um guardião de sementes, no município de Palmitos, Santa Catarina, 2016.

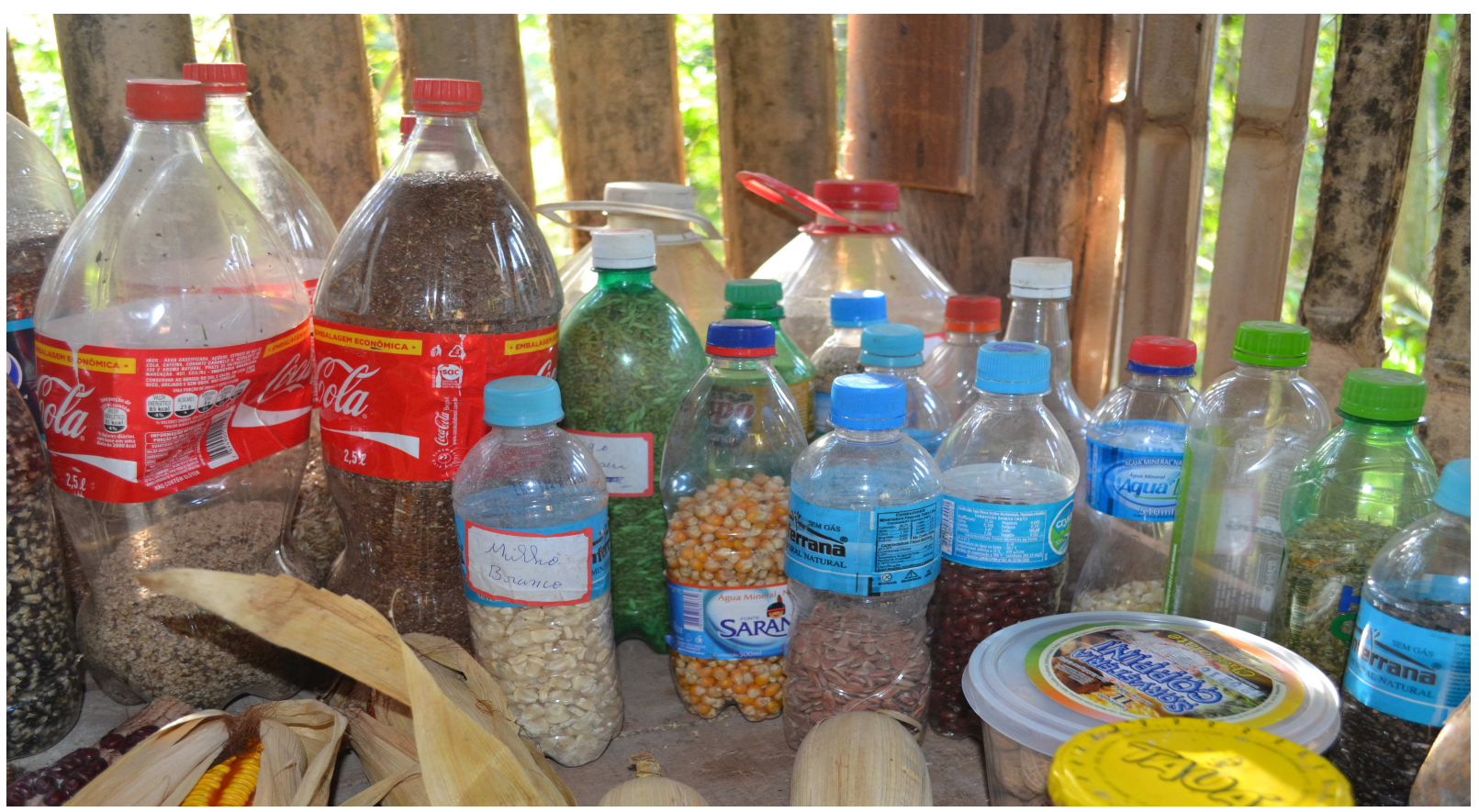

As sementes e o quê os cientistas convencionaram chamar de recursos genéticos por um longo período foi coletado, cultivado, selecionado e melhorado pelos camponeses, até mesmo incentivado pelo Estado para que variedades de outros continentes pudessem aqui se adaptar como são os casos das culturas amplamente cultivadas no país, tais como milho, soja, café, arroz, trigo, feijão, entre outras.

De acordo com Kloppenburg (2004) foi a possibilidade de tornar a semente uma mercadoria $^{64}$ (commodity) que permitiu ao capital transformar a agricultura em uma atividade totalmente integrada ao sistema capitalista. E essa mudança essencial foi alcançada, primeiramente, pelo avanço da ciência agrícola por meio do melhoramento genético de plantas e, logo depois, pela biologia molecular e engenharia genética, desenvolvida a partir do modelo norte americano. Ela permitiu não apenas alcançar aumento de produtividade, mas, sobretudo, redesenhou a agricultura para além de suas porteiras (fronteiras). Adaptou as variedades para que as mesmas pudessem suportar altas cargas de insumos, leia-se adubos

\footnotetext{
${ }^{64}$ De acordo com Castree (2003), analisando o conceito marxista de mercadoria, para um produto ou processo ser considerado como tal, na totalidade do termo, deve apresentar seis aspectos combinados, a saber: privatização, alienação, individuação/separação, abstração, valoração e deslocamento, sendo o caso das sementes, um autêntico exemplo de uma commodificação.
} 
químicos e agrotóxicos, como também modificou a arquitetura das plantas para possibilitar a mecanização, substituindo os trabalhadores rurais e camponeses por máquinas.

Esse processo foi caracterizado pelo embate entre o capital, o Estado e a sociedade. Em que o Estado, ora protegia os agricultores, ora o capital, e fortemente alicerçado no desenvolvimento da ciência e de inovações tecnológicas como, por exemplo, o desenvolvimento de híbridos e, mais recentemente, dos transgênicos. Como afirma Kloppenburg (2004) "Scientific research had been channeled toward elimination of the biological barrier that the seed posed to capital [...]" (pg. 105). Pode-se considerar que as consequências econômicas e sociais dessas mudanças no campo já estão bem discutidas por autores de várias áreas das ciências sociais. Pouca atenção tem sido dispensada a perda progressiva que camponeses, em especial, vem perdendo na sua autonomia, ao serem muitas vezes obrigados a adquirirem novos híbridos/transgênicos anualmente para a realização de seus plantios na medida em que estão não apenas obrigados por leis internas, mas sobretudo pela diminuição da oferta de variedades crioulas ou convencionais no mercado.

Além disso, do ponto de vista estratégico e da soberania alimentar a perda acelerada e contínua da agrosociobiodiversidade aí envolvida e que caracteriza esse processo desde a década de 1970, quando o processo de hibridação foi quase totalmente universalizado, bem como a erosão genética tornou-se uma preocupação não apenas dos ambientalistas, mas também dos próprios cientistas que enxergam esses recursos como matéria prima para o seu trabalho (KLOPPENBUR, 2004).

A década de 1980 representou um período importante na compreensão dos camponeses, em especial, em Santa Catarina, sobre a crescente dependência de insumos (produtos) externos às suas propriedades que os mesmos vinham utilizando para dar continuidade à reprodução de suas lavouras. Essa percepção foi fortalecida a partir do momento que os mesmos realizaram, coletivamente, os cálculos básicos de seus custos de produção durante uma reunião no sindicato de trabalhadores rurais no município de Anchieta. Constataram que o item sementes onerava sobremaneira seus sistemas produtivos porque eles tinham perdido o hábito tradicional de selecionarem as melhores sementes e guardarem para o próximo plantio como faziam anteriormente. Essa percepção fez com que eles decidissem iniciar um trabalho de recuperação das sementes crioulas no município.

Segundo Canci (2002), os trabalhos com resgate de milhos crioulos no estado de Santa Catarina, tem um marco importante com a realização de encontros no Centro Vianei de Educação Popular onde foi debatido a constituição da rede Milho que teve abrangência nacional, ainda nos idos de 1986. Muitos dos dirigentes e camponeses que compõem a base 
do MPA participaram ativamente dessa rede colaborando com os ensaios nacionais de sementes crioulas.

Essa situação expressa exatamente o que descreve Kloppenburg (2004) para o caso dos agricultores americanos no início do processo da aquisição dos híbridos em que a semente se tornou progressivamente por meio das tecnologias, primeiramente, de melhoramento genético, e depois pela engenharia genética e molecular, uma mercadoria. Neste contexto, a tendência é que os camponeses percam também a autonomia de seus sistemas produtivos na medida em que necessitam retornar anualmente para a compra de um dos elementos mais importantes para a reprodução de seus sistemas produtivos, a semente.

Como descrito em IBAMA (2006) e confirmado no trabalho de campo desta tese, foi a partir da direção do Sindicato dos Trabalhadores na Agricultura Familiar (Sintraf) do município de Anchieta, município que dista aproximadamente $43 \mathrm{~km}$ do município de São Miguel do Oeste, que as primeiras experiências com o resgate de sementes crioulas foi iniciado e será fundante e estruturante na estratégia que narrarei a seguir com base nos diálogos e testemunhos dos camponeses, dirigentes e técnicos de instituições que o MPA reuniu em torno de seu projeto. Assim descreve um dos camponeses que participou do processo:

Em 96, 97, teve uma crise da agricultura muito violenta que os insumos eram caro, a semente era cara, era tudo caro...e começou dá estiagens.. dá problemas ...e o preço não tava bom... só tinha custo...que tinha parado com as sementes crioulas....e daí...aqui no sindicato...eu fazia parte da direção do sindicato...o presidente do sindicato era o Leucy ....por que nossos pais, nossos avós nunca compraram sementes e viviam bem? Produziam e viviam bem? Aí peguemos, sentemos e planejamos isso..entre 4, o Zuck e o Adriano Canci (que eram técnicos) e eu e o Carpejani. Planejemos de fazer essa busca de sementes crioulas. Fazer um resgate, né e dali comecemos a fazer, fazer um, fizemos um planejamento, pra ir discutir com a sociedade. Passamos em toda as muradas, de casa em casa com carro nós ia a comunidade, depois nós ia a pé fazer os convite pra vir de manhã até a tarde, as duas horas, fazer uma reunião com todos e discutir isso. Aí tinha gente que chamava a gente de louco, tinha gente que diziam vocês são burro, vocês são atrasados ....e foi onde a gente começou ir buscar e aí a gente foi encontrar as sementes, quem tinha, quem não tinha. Quem pensava que nem a gente pensou, por alí a gente começou a história. E aí no ano 98, a gente fez a Primeira Festa da Semente Crioula municipal, onde que foi um sucesso, nós reunimos 10 mil pessoas. Anchieta tem 6.000, 7.000 pessoas e aí daquela, terminou a festa, fomos para a criação do MPA. Na semana seguinte, fomos fazer a fundação do MPA, em Ronda Alta, fiquemos lá uma semana. E daí já ... aí a aposta da semente crioula....aí pelo Amor de Deus, cara...como levaram sementes daqui...e aí que começou a questão da semente a disseminar. Já tinha um pequeno movimento do MPA no Rio Grande (do Sul), e aqui também tinha um pequeno começo, depois 
tinha lá na Bahia, tinha em vários estados e tinha um começo do MPA. E dali vamos dizer que o pessoal do MPA convidou o sindicato de Anchieta para fazer parte daquela vez, fomos daqui com um ônibus cheio, eu acho [...] fomos um ônibus cheio de Anchieta para o movimento lá, da fundação. O sindicato encampou (Entrevista, 2016).

Esse processo de resgate tornou-se um projeto estratégico da direção do sindicato e mobilizou as famílias camponesas do município a participarem não apenas do resgate, mas também do projeto de produção de sementes crioulas (CANCI, 2002). No princípio, esse movimento de resgate reuniu 26 famílias no município, quando então inicia o processo com forte apoio de técnicos ligados à extensão rural no município, realizada pela Epagri, e fortemente reconhecido pelos camponeses como, por exemplo, os técnicos Ivan e Adriano Canci. Esses dois técnicos colaboraram na construção do resgate e registro dessa agrobiodiversidade no município.

Atualmente, o sindicato possui um banco de sementes que envolve o Movimento de Mulheres Camponesas (MMC), o MPA, a Igreja Católica e a Epagri em um sistema de trocatroca, no qual o camponês tem acesso à semente que necessita e, no ano seguinte, devolve a mesma quantidade da cultivar que utilizou ou outra que disponha. Esse banco abastece não apenas camponeses do município de Anchieta, mas dos municípios do entorno e mesmo de outros estados. Além do banco, há um horto medicinal em uma área nos fundos do sindicato e é uma iniciativa também em colaboração com a Epagri. Esse processo toma visibilidade com a realização das festas do milho crioulo, na década dos 2000.

Com a fundação do MPA, em 1996, alguns dos dirigentes do sindicato irão compor a direção do movimento, tanto em nível estadual quanto nacional. Assim, no ano de 2000, com o MPA já constituído, é realizado a $1^{\mathrm{a}}$ FEMIC - Festa Estadual do Milho Crioulo, idealizada localmente, com forte influência dos técnicos extensionistas locais, que envolveu não apenas os camponeses, mas a comunidade do município, órgãos governamentais como secretarias, Banco do Brasil, Igreja e organizações não governamentais.

No ano de 2004, a festa que era dos camponeses do estado de Santa Catarina nacionaliza-se e transforma-se na Festa Nacional do Milho Crioulo - I FENAMIC congregando camponeses de todo o país, reunindo mais de 30.000 pessoas num município com uma população de 6.380 habitantes (Censo, 2010). De festa nacional do milho crioulo transformou-se na Festa Nacional das Sementes Crioulas (SNSC). Neste mesmo evento, foi realizada a Festa Internacional das Sementes Crioulas que contou com a participação de várias organizações da Via Campesina internacional. As festas tem uma dinâmica própria, integrando momentos políticos, com debates e análises de conjuntura, seminários, formação 
política e culturais com música, arte e a troca de saberes, conhecimentos, experiências e sementes.

Como afirma Londres (2014), as festas desempenham um papel importante tanto na conscientização da importância da preservação da agrobiodiversidade, quanto no fortalecimento da diversidade genética, na medida em que há uma intensa troca tanto de conhecimentos e experiências quanto de material genético dos camponeses, permitindo que essas sementes possam ser plantadas em diversos ambientes. No caso das festas organizadas pelo MPA, que já se encontra na sua quinta edição - 2000, 2002, 2004, 2007 e 2012 - são realizados também o Encontro Nacional de Formação Camponesa (NERLING et al., 2013). Esse movimento tornou o município de Anchieta na capital catarinense e brasileira do Milho Crioulo. Em julho de 2017, foi realizado um seminário para discutir a implementação da Indicação Geográfica dos milhos crioulos do município de Anchieta e região, um reconhecimento do acúmulo, esforço e trabalho de seus camponeses. Vale salientar que todos os anos os agricultores continuam fazendo a festa mais regionalizada.

É importante ressaltar que os transgênicos nesse período, década dos 2000, avançava as fronteiras do país, entrando ilegalmente pelas bordas da vizinha Argentina, pelo estado do Rio Grande do Sul. Este país já havia regulamentado seu plantio e cultivava os transgênicos desde 1996, logo após os Estados Unidos, 1995 (LEGUIZAMÓN, 2014). As festas do milho crioulo se transformaram num importante instrumento político de visibilidade e convencimento que sim, o plantio de sementes crioulas, ainda permanecia presente e relevante. Ao mesmo tempo, várias organizações da sociedade civil debatiam a ação das gigantes globais do setor agrícola na ação vitoriosa para a regulamentação da produção de organismos transgênicos no país, em $2003^{65}$.

As feiras consolidaram-se em um espaço de discussão para o desenho da estratégia não apenas pela ampla participação de camponeses vindos de várias partes do país, mas também, pela possibilidade do diálogo com cientistas, intelectuais e ativistas de ONGs que colaboraram no debate sobre temáticas como agroecologia, agrobiodiversidade e construção de autonomias para um modelo de agricultura que dialogue e respeite os processos naturais e que confirmam o que camponeses e suas organizações vivenciam na prática. No ano de 2007, por ocasião da realização da feira, a realidade já demostrava que diante do avanço dos

\footnotetext{
${ }^{65}$ À época foi organizado um acampamento, intitulado Acampamento Nacional contra os Transgênicos, pela Soberania Nacional e pela Alimentação Saudável, em Brasília, na área de Camping, que reuniu mais de 400 trabalhadores rurais de todas as regiões do Brasil e diversas organizações sociais, tais como MPA, MST, MAB, ANMTR (atual MMC), Fetraf/Sul/CUT; Rede Ecovida de Agroecologia e Asa/PB (Ver: http://aspta.org.br/campanha/boletim-177-22-de-setembro-de-2003/) Última consulta em 17.12.2017.
} 
transgênicos no país, havia a necessidade de uma estratégia nacionalmente articulada e práticas mais consistentes para dar suporte as iniciativas de resistência, seja de reconversão agroecológica, orgânicas e a criação de alternativas às sementes híbridas e transgênicas das multinacionais do setor.

Esse debate sobre a construção de uma estratégia que pudesse fazer frente ao avanço dos transgênicos, e ao mesmo tempo, subsidiar as iniciativas orgânicas e agroecológicas dos camponeses tem um importante papel na decisão do MPA de assumir um projeto de massificação na medida em que para seus dirigentes o armazenamento das sementes crioulas realizada pelas famílias camponesas, individualmente, (simbolicamente representadas pelas garrafas Pet) ou de forma comunitária por meio de casas de sementes no novo contexto tornavam-se formas bastante fragilizadas e de alcance restrito aos camponeses organizados, no âmbito local ou no máximo regional. Fazia-se necessário pensar uma forma de alcance mais ampla e mesmo os ativistas, cientistas e técnicos que animavam o debate sobre as transformações necessárias para uma agricultura agroecológica deixavam claro que sem a disponibilidade de sementes crioulas o projeto de autonomia camponesa estaria em risco. Esse debate se expressará mais claramente durante a formulação da Planapo como discutida por Fernandes, G. (2017).

A experiência mostrava que as formas de armazenamento, historicamente realizada pelos agricultores, ainda que válida e importante, seria insuficiente para a estratégia de massificação uma vez que as mesmas apresentavam problemas com relação, principalmente, a disponibilidade de sementes suficiente para abastecer os camponeses cuja área de produção ultrapasse mais que 3 hectares, os quais exigem uma demanda maior de quantidade de sementes de uma mesma variedade para o plantio, por exemplo. Assim, a questão do armazenamento tornou-se importante na formulação da estratégia de massificação. Afinal, era uma questão da vivência prática dos camponeses no território e importante a ser considerada uma vez que há uma disputa concreta sobre qual modelo de agricultura seguir e a semente é o primeiro insumo nesta definição e precisa estar disponível em quantidade e qualidade.

Assim, estava claro para o movimento que apenas a crítica e a denúncia já não eram mais suficiente, os camponeses exigiam muito mais que a manifestação, era chegada a hora de constituir uma resposta concreta e o projeto de massificar a experiência local foi o caminho escolhido, o qual foi fortemente debatido no contexto do Plano Camponês. Desse modo, é possível perceber que havia um processo intenso de debates dentro e fora do movimento, ou seja, na sociedade, sobre os problemas que envolvia a continuidade da dependência a sementes híbridas e transgênicas. Assim a ideia de massificação da produção de sementes 
crioulas se fortaleceu como um caminho a ser construído e, na sequência a constituição de uma usina de beneficiamento de sementes na medida em que o volume de produção de sementes cresceu, tornando-se impraticável a realização do beneficiamento manual.

A experiência anterior vivenciada pelo sindicato dos agricultores familiares de Anchieta, bem como, de outras associações e cooperativas de onde provinham alguns camponeses e dirigentes ligados ao MPA foi de fundamental importância para o desenho e articulação da estratégia que foi colocada em campo. Antes de constituir a Oestebio, onde se encontra instalada toda a estrutura da usina de beneficiamento e armazenamento das sementes crioulas e varietais, no município de São Miguel do Oeste, no estado de Santa Catarina, foi preciso desenhar, articular e implementar o envolvimento dos camponeses numa estratégia de alcance mais amplo. Para tanto, a constituição de uma rede de camponeses com atividades distintas nesse processo foi instituída.

Figura 4 - Registro realizado por ocasião de pesquisa de campo pela autora, no paiol de um guardião de sementes, no município de Palmitos, Santa Catarina, 2016.

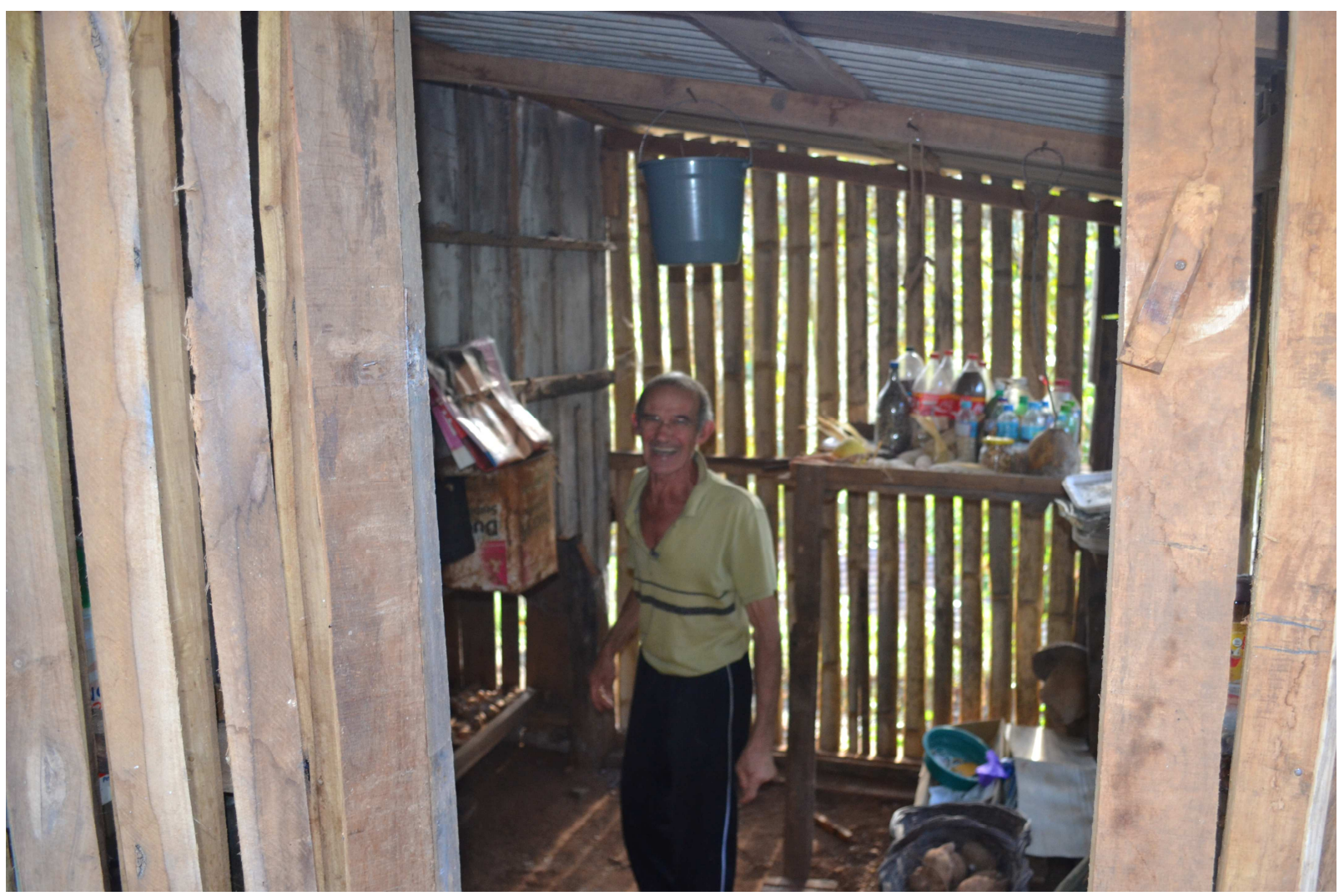


A rede envolve os mantenedores - que cuidam ativamente das sementes - que são os camponeses que selecionam e multiplicam as sementes crioulas e são considerados pelos técnicos e cientistas como os guardiões ${ }^{66}$ e representam o primeiro elo desta rede. Eles que historicamente selecionam, coletam, armazenam e reproduzem as sementes crioulas. Tem um papel fundante porque são os que cuidam/conservam/melhoram o patrimônio genético das culturas plantadas no país, sobretudo, aquelas que compõem a dieta alimentar cultural e, em condições reais ao redor do território nacional. São os primeiros fornecedores e o movimento possui um profundo respeito pelo trabalho desses camponeses. De acordo com seus dirigentes, no decorrer do processo, conseguiram reunir, até o momento da pesquisa de campo desta tese, mais de 300 guardiões de sementes crioulas, espalhados em 55 municípios.

Um segundo elo são os multiplicadores cujo principal papel é a reprodução das sementes crioulas e também varietais para a distribuição no mercado. No início do projeto alguns mantenedores também participavam deste segundo nível da rede. Diferentemente da constituição da rede de mantenedores, a rede dos multiplicadores exigiu um trabalho formativo mais amplo na medida em que envolvia todo um processo de produção que atendesse às exigências técnicas da legislação da produção de sementes no país. Assim, o MPA, na figura da associação estadual formulou e submeteu projetos de assistência técnica e extensão rural para os editais públicos (chamadas públicas) coordenados e financiados pelo $\mathrm{MDA}^{67}$, à época, para a contratação de uma equipe técnica. Essa equipe colaborou tanto no processo formativo dos camponeses multiplicadores - na formação técnica para a produção de sementes - quanto no acompanhamento às famílias que formam a rede e seus campos de produção de sementes em funcionamento - fornecendo assistência técnica.

Esse processo é necessário tanto em função das exigências das regulamentações do Ministério da Agricultura quanto para legitimar todo o processo do ponto de vista 'técnico' e 'científico'. Nesse processo inicial, o MPA envolveu técnicos, pesquisadores e professores da UFSC, Embrapa e Epagri para dar suporte técnico e político-institucional na

\footnotetext{
${ }^{66}$ Carvalho (2013) considera o camponês guardião da agrobiodiversidade, aqueles que historicamente praticam “[...] a diversidade de cultivos e criações, a preservação e melhoria dos solos e das matas, a diversidade das vidas nas águas, o convívio antrópico construtivo e respeitoso com a natureza [...]" (pg. 14). Ou seja, aqueles camponeses que vem reproduzindo secularmente seus sistemas produtivos diversos como é o caso de vários dos guardiões pertencentes à rede do MPA. Por outro lado, Bevilaqua et al. (2014) considera guardiões de sementes aqueles camponeses que mantêm suas sementes por meio da reprodução através do tempo e que tem o reconhecimento da comunidade onde se insere.

${ }^{67}$ O Ministério do Desenvolvimento Agrário foi criado no ano de 2000, após passar pela designação de Ministério da Política Fundiária e do Desenvolvimento Agrário, fruto da pressão e visibilidade que ganhou o massacre dos trabalhadores rurais sem terra, ligados ao MST, ocorrido em 1996, em Eldorado do Carajás, no estado do Pará (FERNANDES, 2015). O mesmo foi extinto, em 2016, logo após a destituição da Presidenta eleita Dilma Rousseff, sob a dúbia alegação de crime de responsabilidade, o que, para muitos, configurou um golpe à democracia no país.
} 
institucionalização de seu projeto nacional de produção de sementes fiscalizadas. Esse trabalho conjunto resultou em diversas modificações no projeto original, fruto das trocas e dos diversos aprendizados que o movimento e os camponeses acumularam no decorrer do processo, incluindo a decisão de produzir as variedades provenientes da pesquisa pública, denominadas de variedades de polinização aberta ou sintéticas ${ }^{68}$.

A decisão de massificar a produção de sementes crioulas e, depois, de variedades da pesquisa pública, implicou a aquisição e apropriação de uma variedade de conhecimentos não apenas técnicos per se, mas sobretudo, do marco legal e tecnológico que regulamentam a produção de sementes fiscalizadas no país, como também capital financeiro, político e social para a construção de um empreendimento socioeconômico de uma envergadura empresarial que é a constituição de uma cooperativa, a Oestebio, e a estruturação de uma usina de beneficiamento e armazenamento de sementes fiscalizadas com capacidade estimada em 4000 toneladas.

Não que seja exatamente uma novidade visto que alguns desses camponeses, em particular, no sul do país, possuem um histórico de experiências em constituir cooperativas, bem como produzir sementes. A novidade aqui é que esta iniciativa tem um projeto político de soberania alimentar que a sustenta. Assim, para melhor compreender os desafios que seriam enfrentados pelo MPA é importante salientar as peculiaridades técnicas e o sistema regulatório e institucional com relação à produção e comercialização de sementes no Brasil e de como o movimento gestou uma estratégia para implementar o projeto de massificação da produção de sementes dialogando com o seu projeto político de soberania alimentar e que demonstra que a articulação de diferentes parceiros no caminho foi fundante para o sucesso desta caminhada.

Em primeiro lugar, é mister esclarecer as exigências que regulamentam um campo de produção de sementes para atender o projeto idealizado e implementado pelos camponeses sob a coordenação política do MPA e efetivado, primeiramente, pela associação e mais tarde pela Oestebio. Abrirei um parêntese aqui para explicitar em que ambiente normativo, institucional e de mercado o MPA estava se inserindo. Com esta realidade preemente a sua frente, o MPA se cercou de várias das principais autoridades e instituições nesse campo, tanto do ponto de vista técnico quanto científico, com as quais o MAPA não poderia negar-lhe a

\footnotetext{
${ }^{68}$ As variedades de polinização aberta - VPAs - são consideradas cultivares com variabilidade genética mais ampla que os híbridos, pois são produto de processos de melhoramento com população de plantas que se intercruzam livremente e podem ser utilizadas pelos camponeses para o plantio seguinte sem diminuição da sua produtividade (REUNIÃO, 2013).
} 
concessão para atuar nesse mercado em que, mais tarde colaboraria a luz da própria experiência para instituir, o mercado de compras institucional com foco na comercialização de sementes e influenciar a formatação do eixo Sementes na Planapo.

Figura 5 - Registro realizado por ocasião da pesquisa de campo pela autora, na Usina de Beneficiamento da Cooperativa Oestebio do MPA, em São Miguel do Oeste, Santa Catarina, em 2016.

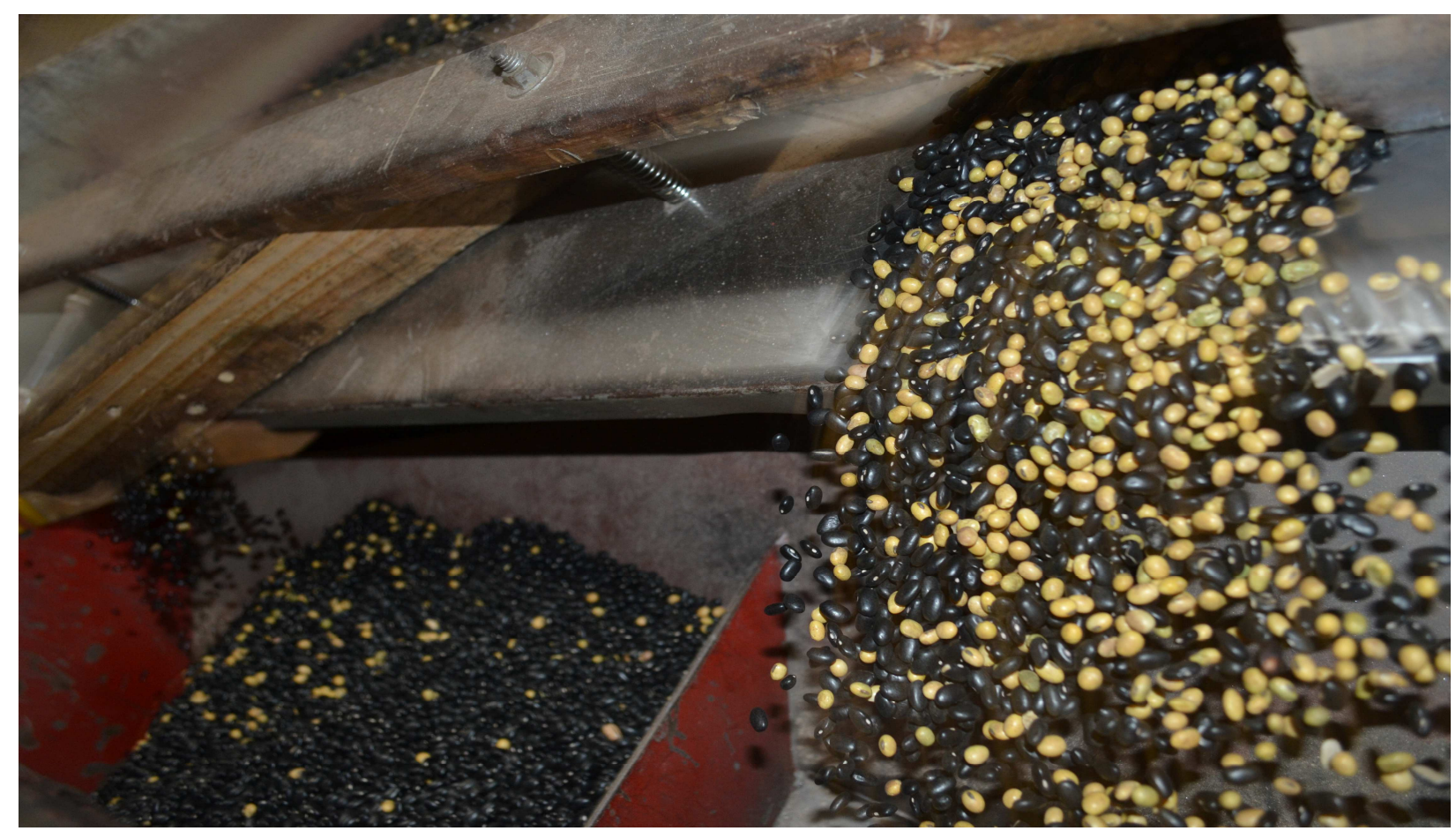

\subsection{CONTEXTO INSTITUCIONAL, NORMATIVO E POLÍTICO}

Polanyi (2012) considera a criação do mercado autorregulável uma das maiores inovações/invenções humanas e neste universo tanto a natureza quanto a humanidade se transformam em mercadoria. Foi essa inovação que criou a crença de que as ações e comportamentos do homem na vida cotidiana devem estar baseados na busca do lucro. Para operar desta forma, segundo o autor, a instituição mercado subordina todo o sistema social ao sistema econômico. Esse processo pode ser perfeitamente observado no caso da produção de sementes, no decorrer do último século.

Para Kloppenburg Jr (2004) a pesquisa científica, aí incluída a ciência básica e a tecnológica, vem desempenhando um importante papel para a entrada do capitalismo na agricultura, desconstituindo barreiras naturais, anteriormente intransponíveis, para possibilitar formas de transformação da natureza em mercadoria que possam ser apropriadas pelo capital. 
O caso do melhoramento de plantas e, na sequência, a engenharia genética e as biotecnologias estão entre os principais fatores responsáveis pela transformação das sementes em mercadoria em um mercado altamente lucrativo.

Tanto Polanyi (2012) quanto Kloppenburg Jr (2004) afirmam que para a realização dessas duas inovações - a criação do mercado autorregulável e o mercado de sementes - o estado desempenhou um papel preponderante na regulamentação desses novos sistemas, não apenas no suporte e desenvolvimento da ciência, mas especialmente na produção de normatização para permitir a apropriação desses bens, historicamente públicos e livres para a nova condição de privatizados e obstruídos.

Segundo Schenkelaars et al. (2011) a indústria mundial de sementes vivenciou três grandes mudanças estruturais até alcançar o estágio atual. A primeira dessas mudanças, no início dos anos de 1930, foi representada pelo surgimento das firmas de sementes comerciais que a partir da apropriação dos resultados da pesquisa pública em melhoramento de plantas, centrada na produção de híbridos, especialmente, milho, abriu espaço para o interesse do capital em tornar este setor um mercado lucrativo. Nesse período, o Estado dominava não apenas a pesquisa, mas era o principal fornecedor de sementes para os agricultores.

Um segundo momento de reestruturação deu-se no contexto da revolução verde, nos anos de 1970, apoiada por um novo marco regulatório com relação à apropriação dessas inovações provenientes do melhoramento genético. Estes novos mecanismos de apropriação conhecidos como "direito de propriedade intelectual" como, por exemplo, o direito dos melhoristas de plantas e a aquisição de patentes abriram uma avenida para que os investimentos em pesquisa e desenvolvimento $(\mathrm{P} \& \mathrm{D})$ por meio das inovações tecnológicas viessem a ser cobrados dos agricultores. A partir desta conjunção de fatores, resultados da pesquisa científica e de um novo quadro normativo, grandes empresas dos setores farmacêuticos, petroquímicos e agroquímicos iniciaram a fusão e aquisição de empresas locais e regionais, primeiramente nos Estados Unidos da América do Norte e Europa e, depois, ao redor do mundo (SCHENKELAARS et al., 2011; WILKINSON; CASTELLI, 2000; KLOPPENBURG JR, 2004).

O terceiro momento, iniciado na década de 1980, caracterizou-se pela ação das grandes multinacionais do setor, provenientes dos Estados Unidos da América do Norte e da Europa, fortemente apoiadas nas novas biotecnologias - genomas, engenharia genética (organismos geneticamente modificados) - que redesenharam completamente o setor de produção de sementes ao redor do mundo via a imposição de regras criadas em seus próprios países de origem para os demais países, especialmente, os países subdesenvolvidos, no 
contexto da Rodada do Uruguai do GATT (1986-1994) por meio da celebração do acordo TRIPS 69 - Acordo sobre Aspectos do Direito de Propriedade Intelectual relacionados ao comércio (SCHENKELAARS et al., 2011).

O que pode ser observado na literatura consultada é que desempenharam papéis preponderantes nessas mudanças estruturais do setor, atuando em conjunto com as descobertas científicas, as políticas governamentais, em âmbito internacional e nacional, estando aí inseridas a aplicação de leis de propriedades intelectuais, políticas de apoio financeiro e isenções fiscais ${ }^{70}$, criação de um forte sistema regulatório e as estratégias de expropriação de lucro das multinacionais. Vejamos como isso se operou no Brasil e seus desdobramentos para a agricultura como um todo e para a camponesa em particular na medida em que tais transformações afetam não apenas o setor de sementes, mas toda a base tecnológica em que se baseia a agricultura. A semente neste novo modelo torna-se o principal vetor tecnológico na medida em que carrega consigo um modelo de agricultura subordinado totalmente a lógica do capital.

Para o caso brasileiro em particular, de acordo com França-Neto e Oliveira (1998), os anos de 1920 marcam o início da criação do sistema de abastecimento de sementes no país por meio da instituição do Serviço de Sementes no Ministério da Agricultura. O ministério seguiu com esta tarefa de fornecimento de sementes aos agricultores até os anos de 1950, em conjunto com algumas secretarias de estados. A partir desse período, abre-se a possibilidade da entrada de empresas privadas ocuparem o setor direcionada, especialmente, àqueles agricultores com recursos financeiros disponíveis. Antes disso, porém, no estado de Minas Gerais, ainda nos anos de 1940, nascia a Agroceres, a primeira empresa nacional que com o suporte da Universidade Federal de Viçosa inicia a comercialização de híbridos no país (CORDEIRO et al., 2007; WILKINSON; CASTELLI, 2000).

Mas, é a partir da década de 1960, especificamente em 1965, que houve a promulgação da primeira Lei de Sementes brasileira que instituiu um Plano Nacional de Sementes - o PLANASEM, fortemente baseado nas experiências das secretarias dos estados do Paraná e Rio Grande do Sul. Esse plano deu organicidade ao sistema de produção de sementes por meio do compartilhamento de responsabilidades aos diferentes entes da federação - união e estados - reconhecendo as experiências acumuladas nos estados

\footnotetext{
${ }^{69}$ Agreement on Trade-Related Aspects of Intellectual Property Rights.

${ }^{70}$ Segundo Silva Júnior (2017), o BNDES, no ano de 2014, concedeu crédito de R\$ 9,8 milhões para a Sakata Seed América do Sul para seu programa de melhoramento de hortaliças; a TMG (Tropical Melhoramento Genético) possui todo o banco de germoplasma de soja da Embrapa e o estado do Mato Grosso instituiu o PROALMAT (Programa de Incentivo ao Algodão de Mato Grosso - Lei nº 6.883, de 02 de junho de 1997) que concedeu até 75\% de restituição do ICMS para produtos exportados do estado desde 1997.
} 
produtores. Assim, criou-se um sistema composto pelas atividades de produção de sementes básicas e comerciais; treinamento e registro de pessoas e entidades e a criação de entidades certificadoras, no caso, as secretarias dos estados de Minas Gerais, São Paulo, Paraná, Santa Catarina e Rio Grande do Sul. Data desse período, a entrada da primeira multinacional, a CARGILL (CORDEIRO et al., 2007; WILKINSON; CASTELLI, 2000).

Wilkinson e Castelli (2000) ressaltam que é apenas em 1977 que é criado um sistema regulatório compatível com aqueles em vigor nos países desenvolvidos através da Lei Federal 6507/77, cuja regulamentação se dá no ano de 1978. Nesse período, o país já contava com uma rede de instituições para operar o sistema tanto com relação à pesquisa, no qual a Embrapa fazia a coordenação, quanto com relação à assistência técnica através do sistema Embrater ${ }^{71}$, além de políticas de fomento operadas por meio do Banco Central e da Companhia de Financiamento da Produção (CFP).

Esse novo regime cria uma nova estrutura de acompanhamento e fomento por meio da fiscalização da produção e do comércio; uma classificação de sementes e mudas - sementes melhoradas certificadas e fiscalizadas e as não melhoradas - e uma comissão nacional de sementes e mudas - a CONASEM. Nesse período, a comercialização estava centrada nas sementes híbridas pelas empresas multinacionais e pelas cultivares melhoradas desenvolvidas pelo sistema público de pesquisa e um conjunto de empresas e cooperativas do setor sementeiro que multiplicava essas variedades (CORDEIRO et al., 2007).

O que possibilitou a mudança do sistema a partir da década de 1990 foi a celebração do acordo TRIPS que desencadeou as transformações no arcabouço jurídico nacional que afetaria o setor sementeiro no seu conjunto - pesquisa, produção e comercialização. Desse processo resultaram os seguintes marcos legais ${ }^{72}$ que atualmente regulam o setor: Lei de Propriedade Industrial n ${ }^{\circ}$ 9.279/1996, conhecida como Lei de Patentes; Lei de Proteção de Cultivares no 9456 de 1997 e a adesão ao sistema UPOV73 - União Internacional para a Proteção das Obtenções Vegetais - conforme a Ata de 1978, no ano de 1999. Na década

\footnotetext{
${ }^{71}$ Empresa Brasileira de Assistência Técnica e Extensão Rural - EMBRATER - criada pela Lei n $^{\circ} 6126$ de 06 de novembro de 1974 e pelo Decreto ${ }^{\circ} 75.373$ de 14 de fevereiro de 1975 e extinta no primeiro dia do Governo Collor de Mello pelo Decreto no 99192 de 15 de março de 1990 (PEIXOTO, 2008).

${ }^{72}$ Para Londres (2006), os principais instrumentos jurídicos que modificaram a agricultura no último período são os seguintes: Lei Agrícola 8.171/1991; Lei da Propriedade Industrial 9279/1996; Lei de Proteção de Cultivares 9456/1997; Lei nº 9972/2000; Lei no 9973/2000; Lei n 10.711/2003 e Lei de Biossegurança de 2005. Todas essas leis tem seus respectivos decretos regulamentares e instruções normativas.

${ }^{73}$ UPOV - Union Internationale pour la Protection des Obtentions Végètales - responsável pela gestão e implementação da Convenção Internacional para a Proteção das Obtenções Vegetais e está vinculada a Organização Mundial de Propriedade Intelectual (OMPI) - http://www.upov.int/portal/index.html.en.
} 
seguinte, anos 2000, foram editadas ainda: a chamada nova Lei de Sementes $n^{\circ} 10.711 / 2003$ e a Lei de Biossegurança 11.105/2005 (VILLAS BOAS, 2008).

O primeiro desses novos ordenamentos jurídicos, a LPC de 1997, instituiu o direito dos obtentores que equivale ao direito de propriedade intelectual com relação a sementes e mudas. Assim, pessoas físicas ou jurídicas passaram a obter o direito exclusivo de reproduzir e comercializar material genético. A partir daí foi instituído também o Sistema Nacional de Proteção de Cultivares (SNPC), substituindo o Sistema Brasileiro de Avaliacão e Recomendacão de Cultivares (SNARC ${ }^{74}$ ) - composto pelas Comissões Regionais de Avaliação e Recomendação de Cultivares (CRCs) ou Comissões por produto que eram as responsáveis pela condução de avaliação de ensaios nacionais para a recomendação de cultivares no país, realizadas por uma ampla rede de instituições públicas e privadas. Junto com o SNPC 75 responsável pela certificação de proteção de cultivares comerciais que gera a cobrança de royalties ${ }^{76}$ (direitos autorais), foi criado também um novo sistema para controle do registro de novas cultivares chamado de RNC - Registro Nacional de Cultivares. O sistema atual exige a determinação do Valor de Cultivo e Uso (VCU) que é determinado para cada cultivar e cuja responsabilidade na realização e condução dos ensaios é do obtentor da cultivar. Ambos os sistemas estão sob a coordenação do Ministério da Agricultura (VILLAS BOAS, 2008; CORDEIRO et al., 2007).

A segunda importante alteração na legislação veio com a nova Lei de Sementes e Mudas que instituiu o Sistema Nacional de Sementes e Mudas, cujas principais alterações estão listadas abaixo:

a) a certificação sai do âmbito do controle público, antes no MAPA, para o âmbito privado - podendo ser executado tanto por empresas privadas ou pelo próprio produtor de sementes;

b) instituiu até no máximo duas gerações de uso da semente não certificada (S1 e S2) a partir da nova estratificação ${ }^{77}$ de sementes, impondo a aquisição de novas sementes básicas ou certificadas;

\footnotetext{
${ }^{74}$ A rede existiu oficialmente de 1981 a 1987.

${ }^{75}$ Consulta realizada no dia 24 de novembro de 2017 - cultivarweb - no sistema que reúne as informações sobre cultivares no país, havia 2.381 cultivares registradas no sistema. A responsabilidade sobre esse processo está a cargo do MAPA (http://sistemas.agricultura.gov.br/snpc/cultivarweb/cultivares_protegidas.php?txt_ordem $=\& p o s t a d o=1 \&$ acao $=\mathrm{p}$ esquisar\&\&).

${ }^{76}$ A cobrança de royalty é de responsabilidade do obtentor.

${ }^{77}$ A nova classificação de sementes inclui duas categorias - Certificada e Não Certificada. Na primeira categoria a partir da semente genética, temos as categorias da semente básica e certificadas - C1 e C2. Nas não certificadas com origem genética comprovada, S1 e S2. Cada uma refere-se a duas gerações de sementes a partir das
} 
c) estabeleceu maior controle por parte do Estado via MAPA na fiscalização não apenas da produção, mas também do armazenamento, comercialização, distribuição e compartilhamento;

d) criou no MAPA, o Sistema Nacional de Sementes e Mudas (SNSM) composto pelo Registro Nacional de Sementes e Mudas (RENASEM) - registro de pessoas físicas e jurídicas envolvidas no setor sementeiro e o Registro Nacional de Cultivares (RNC) para o controle de cultivares (BRASIL, 2011; LONDRES, 2006).

Ainda segundo Londres (2006), pode ser considerado avanços nessa nova Lei, do ponto de vista dos camponeses e suas organizações, a isenção da inscrição das sementes crioulas no Registro Nacional de Sementes e Mudas ${ }^{78}$, bem como o acesso a programas de financiamento ou programas públicos de distribuição ou troca das sementes dos camponeses. Além disso, o reconhecimento diferenciado no uso de sementes por agricultores e camponeses familiares, populações indígenas e tradicionais.

A terceira grande modificação foi a inclusão no sistema jurídico da legalização do uso de transgênicos (OGM) no país pela Lei da Biossegurança de 2005. A CTNBio (Comissão Técnica Nacional de Biossegurança) ficou responsável exclusiva para o julgamento com relação a segurança dos OGMs e produtos biotecnológicos sob o ponto de vista da saúde humana, animal e ambiental, e as demais questões, em especial, as socioeconômicas são discutidas em outras instâncias. Este marco também criou a Política Nacional de Biossegurança (PNB); o Conselho Nacional de Biossegurança (CNBS) e o Sistema de Informação sobre Biossegurança (SIB), sob a coordenação do Ministério da Ciência, Tecnologia e Inovação - MCTI79 (SILVA JÚNIOR, 2017).

Como envolve interesses díspares, foram longos processos de discussão e debate com os diversos setores, mas veremos que houve vencedores e perdedores. Passados vinte anos, os impactos desse novo marco jurídico não apenas no setor de sementes em particular, mas na agricultura brasileira no seu conjunto sofreram enormes modificações.

A produção de sementes no mundo tornou-se um mercado bastante centralizado e concentrado. Estima-se que no ano de 2016 este mercado tenha mobilizado mais de 53 milhões de dólares (ISAAA, 2016). O Brasil produziu nas últimas safras de 2014/2015, 3.214,210 toneladas de sementes e na safra de 2015/2016, 3.815,655 toneladas de sementes.

categorias anteriores, $1^{\mathrm{a}}$ e $2^{\mathrm{a}}$ gerações (BRASIL, 2011).

78 Não há consenso entre as diversas organizações dos camponeses e das ONGs (Organizações não Governamentais) de apoio sobre os impactos que poderão advir desse processo de inscrição para a autonomia camponesa (LONDRES, 2006).

${ }^{79}$ Atual Ministério da Ciência, Tecnologia, Inovações e Comunicações (MCTIC). 
Atualmente 20 estados brasileiros produzem sementes no país dentre as diversas categorias básica, certificadas $\mathrm{C} 1$ e C2 e não certificadas, S1 e S2. Os principais estados produtores de sementes comerciais em volume de produção estão concentrados no eixo sul, centro-oeste e sudeste, listado na sequência por ordem de grandeza de produção: Paraná, Mato Grosso, Rio Grande do Sul, Minas Gerais, Santa Catarina e São Paulo (ABRASEM, 2016).

No ano de 2016, o Brasil ocupou o $2^{\circ}$ lugar no ranking mundial de área plantada com sementes transgênicas no mundo com 49.1 milhões de hectares, alcançando $27 \%$ da área plantada globalmente, ficando atrás apenas dos Estados Unidos da América do Norte com 72.9 milhões de hectares, equivalendo $39 \%$ da área global. Essa área corresponde aos cultivos de soja, milho e algodão. Estima-se que a área plantada com essas culturas no país, naquele ano, tenha sido de 52.6 milhões de hectares, isso corresponde ao percentual de 93,4\% de áreas plantadas com sementes transgênicas. Esse relatório ainda traz a informação que este mercado mobilizou sozinho no território brasileiro, no período de 10 anos - 2003 a 2015 - valores de recursos de US\$ 16.4 bilhões e, apenas no ano de 2015, o montante de US\$2.5 bilhões (ISAAA, 2016).

O que explica de fato porque tanta preocupação em criar mecanismos de apropriação de recursos anteriormente públicos e de livre acesso por meio de regulamentações proibitivas e privatistas. É importante ressaltar os diversos impactos e efeitos que têm sido registrados tanto no setor de pesquisa quanto no da erosão genética para os camponeses que vivem da agricultura.

De acordo com Wilkinson e Castelli (2000) e Cordeiro et al. (2007) logo após essas modificações na legislação em torno da liberação para a apropriação dos recursos genéticos nacionais, a indústria multinacional do setor iniciou o processo de aquisição de empresas nacionais de sementes, tanto grandes quanto pequenas, com o objetivo de apropriar-se do germoplasma de cultivares adaptados às condições ambientais locais. Assim, um grande número de empresas e cooperativas que atuavam no setor no âmbito regional e local foram incorporadas pelas gigantes do setor, incluindo aí, a mais antiga empresa nacional produtora de sementes no país, a Agroceres que datava de 1945.

Essa abertura também teve grande impacto na organização da pesquisa no setor de sementes no país, não apenas na pesquisa pública, mas no financiamento e direcionamento desta, agora mais do que antes, autorizada a se comprometer com a agenda do mercado. Villas Boas (2008) e Cordeiro et al. (2007) chamam a atenção para o fato de que os ensaios anteriormente realizados por uma ampla rede de pesquisadores em uma diversidade de ambientes, onde era gerado um grande número de informações, foi reduzido e passou a contar 
com o uso intensivo de marketing e propaganda das poucas variedades disponibilizadas pela indústria. O quê se assiste de fato é uma redução no número de espécies pesquisadas, restringindo-se aos cultivos considerados lucrativos como as chamadas commodities, ou seja, as sementes-mercadorias, com pouco espaço para as culturas que compõe a dieta alimentar dos brasileiros.

Os dados da Abrasem (2015; 2016) são esclarecedores, o setor do mercado de sementes no país concentra-se na produção de commodities - soja e milho sozinhos perfazem $74 \%$ do total da oferta nacional, e mais recentemente, as sementes de forrageiras tropicais $11 \%$ e olerícolas $6 \%$, totalizando mais de $90 \%$ do total de sementes produzidas. Ainda de acordo com a Abrasem (2015), havia no Registro Nacional de Cultivares (RNC), no ano de 2015, 30 mil cultivares registrada como de domínio público, sendo que dessas apenas 7\% estavam registradas como cultivares protegidas. Para o caso da soja em particular, havia o registro de 1.300 cultivares com 59\% dessas transgênicas e para o caso do milho, 2700 híbridos registrados, com um percentual de $43 \%$ de transgênicos.

Esses dados confirmam a avaliação de Villas Boas (2008) que a nova regulamentação tem impactado distintamente os diversos tipos de culturas no país, dependendo do poder de atração que exerce sobre o mercado, como por exemplo, sementes de feijão que apresentam baixo interesse desse setor no seu desenvolvimento. O que acarreta uma oferta bastante reduzida dessas variedades com predomínio de obtentores do setor público. Silva Júnior (2017) destaca ainda que a oferta de novos registros de cultivares além de pertencerem às grandes empresas de sementes privadas e multinacionais, focadas em commodities, representa atualmente no caso do milho, em particular, $87 \%$ das variedades registradas e para o caso da soja, $66 \%$.

Mesmo para o caso dos transgênicos o leque das opções de variedades é restrito. A biotecnologia tão propagada restringe-se a duas opções, tolerância a herbicida e/ou à denominada "empilhada" que conjuga a resistência a insetos e a tolerância a herbicida. Todas essas transformações encareceram sobremaneira os custos de aquisição de sementes que passaram a contabilizar $10 \%$ do custo total de produção dessas cultivares vendidas como commodities no mercado internacional, tais como soja, milho e algodão (SILVA JÚNIOR, 2017).

Apesar de todos os esforços que o país tem desempenhado na desregulamentação, desnacionalização e apoio logístico e financeiro, conforme descrito e constatado por Silva Júnior (2017), essas empresas multinacionais tem realizado suas pesquisas no país de origem, comprovado pelos registros na CTNBio dos produtos transgênicos cuja procedência são os 
laboratórios norte-americanos e europeus e que os pesquisadores brasileiros aqui contratados realizam apenas trabalhos burocráticos nas atividades de acompanhamento da regulamentação e de mercado, com exceção de pesquisas realizadas em parceria com a Embrapa e que dizem respeito a soja cultivance e ao Eucalypitus transgênico.

Se por um lado isso é devastador no que tange a aceleração da erosão do patrimônio do germoplasma genético nacional, ou seja, redução da base genética da agrobiodiversidade, pode abrir possibilidades de trabalho para os camponeses desde que haja o mesmo reconhecimento e apoio às iniciativas instituídas por esses pelo lado do estado brasileiro, suas instituições e a pesquisa pública. Como Wilkinson e Castelli (2000) ressaltam essa normatização tem baixo alcance quando se trata das variedades de polinização aberta ou as chamadas sintéticas por conta de sua baixa capacidade de patenteamento, portanto é uma porta que permanece acessível aos camponeses.

\section{SÍNTESE DO CAPÍTULO}

O capítulo registrou a história de constituição do MPA e de como os camponeses constituíram formas de resistência ao frequente processo de expropriação, especialmente, pela apropriação dos meios de produção, no caso presente, suas sementes - que o capital realiza no processo de expansão e consolidação de sua presença no setor agropecuário no país.

Ao mesmo tempo, constituiu uma síntese das mudanças operadas no sistema de regulamentação do setor de sementes no país, no último período, para garantir altas somas de lucros as multinacionais do sistema agroalimentar no mundo e suprimir direitos e a autônomia camponesa. 


\section{CAPÍTULO IV - A CONSTRUÇÃO DA RESISTÊNCIA}

Elaborado a partir das entrevistas com os atores envolvidos no processo, este capítulo narra a constituição da experiência a partir da perspectiva de quem a construiu. Nesse sentido, os 'testimonios' foram fundamentais para tecer a narrativa ora apresentada. Assim, o presente texto objetiva mostrar como os acontecimentos foram construídos em escalas de tempo e espaços distintos, reunindo evidências de como a articulação e a constituição de alianças foram constituindo-se para a concretização da estratégia nos diferentes âmbitos, local, estadual e nacional. Ao mesmo tempo, busca-se situar historicamente as diferentes instituições envolvidas para compreender como cada uma insere-se no processo e marcar suas singularidades.

O texto está estruturado em itens e subitens, separados por temas e instituições, para uma melhor visualização das diferentes políticas públicas envolvidas e como elas se interconectam, mas na realidade concreta, as dinâmicas são mais complexas e simultâneas. Foi um recurso didático utilizado para facilitar a escrita e não perder detalhes do processo narrado.

\subsection{A EXPERIÊNCIA DE MASSIFICAÇÃO - O DESAFIO DE SANTA CATARINA, FAZER A RODA GIRAR}

Contextualizar o ambiente institucional, normativo e político em que a experiência do MPA se constitui é importante para entender as articulações que foram necessárias e possíveis de serem realizadas para que a experiência se concretizasse. A partir do primeiro mandato do governo de Luis Inácio Lula da Silva, articula-se uma rede de políticas públicas, historicamente reivindicadas pelos movimentos sociais, tanto em volume de recursos quanto em inovações no quadro das políticas de apoio a agricultura familiar e camponesa (GRISA, 2012; GRISA e SCHNEIDER, 2014). Dessa forma, o MPA construiu nesse processo capacidades para acessar, manejar, gestar e influenciar essas políticas e que foram fundantes e determinantes no processo de institucionalização dessa experiência. 


\subsubsection{Política Nacional de Assistência Técnica e Extensão Rural -PNATER}

A Política Nacional de Assistência Técnica e Extensão Rural (PNATER) foi formulada pelo CONDRAF/MDA em colaboração com a sociedade civil e os movimentos sociais rurais e lançada no ano de 2004. No ano seguinte, 2005, viria a ser publicado o PRONATER (Programa Nacional de Assistência Técnica e Extensão Rural). Uma de suas inovações mais importantes é a descentralização e a execução desses serviços passarem a ser realizados por entidades estatais e não estatais que permitem que organizações como associações, sindicatos e cooperativas ligadas ao movimento participem na prestação desses serviços (PEIXOTO, 2008).

Pode-se considerar a partir dos diálogos com os representantes do MPA e técnicos da cooperativa que uma das primeiras políticas de apoio ao projeto foi a Política Nacional de Ater que deu sustentação a formação e capacitação técnica tanto dos técnicos contratados como da rede de camponeses multiplicadores de sementes em colaboração com as experiências anteriores da rede de mantenedores/guardiões de sementes. No primeiro momento, essa rede envolveu camponeses da base do MPA e, conforme a experiência foi se desenvolvendo - os desafios, contradições e aprendizagens começaram a despontar - foram envolvidos outros camponeses que não pertenciam organicamente ao movimento. É importante salientar que nesses primeiros anos, o movimento acessava as políticas públicas por meio da associação estadual do $\mathrm{MPA}^{80} /$ Santa Catarina. Em 2006, essa associação conseguiu aprovar o primeiro projeto para fornecimento de assistência técnica aos camponeses envolvidos no processo no estado.

Esses projetos de ATER eram renovados anualmente o quê obrigava a constante renovação do processo de contratação de técnicos e elaboração de projetos. Com a contratação de um projeto com uma amplitude maior e temporalidade mais longa com o Ministério da Pesca, objetivando a elaboração de um projeto de pescado de água doce na região, viabilizou-se a composição de uma equipe maior, com vinte técnicos, o qual fortaleceu várias estratégias, entre as quais, a produção de sementes. Os técnicos discutiam a propriedade como um todo e não apenas a possibilidade de instalação de sistemas de pescados. Essa abordagem mais sistêmica de compreensão dos sistemas de produção e de organização da propriedade garantiu que a equipe técnica trabalhasse em várias frentes, fortalecendo os diversos projetos em campo e respondendo as características da agricultura

\footnotetext{
${ }^{80}$ No portal da transparência do governo federal encontra-se registrado todos os aportes financeiros realizados pelos diferentes projetos que o MPA operou durante o período - 2003-2015, tais como os de assistência técnica, construção da UBS, entre outros (http://www.portaltransparencia.gov.br. Acesso 18.11.2017).
} 
camponesa. A garantia dessa abordagem transformou o técnico num agente articulador do processo, onde se constituiu a ponte que ligava o camponês à política pública. Essa equipe técnica participou ativamente em conjunto com os camponeses do processo de capacitação em torno dos sistemas de produção de sementes.

A rede foi sendo constituída por meio de um processo intenso de formação e capacitação que envolveu as instituições de ensino (UFSM), pesquisa e extensão rural do estado de Santa Catarina (EPAGRI) e a Embrapa, fortemente centrado em sistemas de produção de sementes, bem como na troca de experiências com outras organizações de camponeses que já estavam trabalhando com a produção de sementes crioulas.

Uma das primeiras atividades do processo formativo foi a troca de experiências com organizações de camponeses. Os treinamentos eram realizados duas vezes ao ano, no decorrer de uma semana intensa de debates teóricos e técnicos que versavam desde a concepção do projeto de massificação à produção, beneficiamento, legislação e comercialização em torno da produção e tecnologia de sementes. A primeira troca de experiências ocorreu com a organização denominada UNAIC 81 (União das Associações Comunitárias do Interior do Canguçu), do município de Canguçu, no Rio Grande do Sul, onde há também uma unidade de beneficiamento. Com a troca de experiências com esses camponeses, eles tornaram-se conhecedores de uma parceria que a UNAIC possuía com pesquisadores da Embrapa Clima Temperado $^{82}$ e a partir daí, iniciaram os contatos com uma rede de pesquisadores desta unidade que passaram a colaborar no processo e articular outras unidades, bem como a unidade central, a sede.

Os camponeses queriam saber o que diferenciava um campo de produção de sementes de uma lavoura convencional, cujo objetivo é a produção de grãos, por exemplo. Quais os conhecimentos necessários para alcançar uma semente de qualidade em conformidade com a legislação e os critérios do mercado. E nesse sentido, eles tiveram uma resposta bastante positiva das instituições que eles buscaram/procuraram, vinha uma equipe inteira para assessorá-los, de pesquisadores a laboratoristas, para discutir a concepção do projeto e a operar a usina, da parte da produção a tecnologia de sementes; da legislação a rede de contatos para chegar onde a burocracia está. E cada nova exigência que surgia, uma instituição vinha para apoiar. A identificação da contaminação por transgênicos foi uma

\footnotetext{
${ }^{81}$ UNAIC - União das Associaç̃es Comunitárias do Interior de Canguçu (http://unaic.blogspot.com/p/sementescrioulas.html).

${ }^{82}$ O Centro de Pesquisa Agropecuária de Clima Temperado - Embrapa Clima Temperado - cuja sede está localizado no município de Pelotas/RS, data de 1973, mas sua origem vem desde 1938, com a criação da Estação Experimental de Viticultura, Enologia e Frutas de Clima Temperado. Disponível https://www.embrapa.br/climatemperado/. Último acesso em: 11.11.2017.
} 
importante contribuição da UFSC para que o processo não paralizasse. Introduziram conhecimentos da legislação e apresentaram os caminhos para a entrada no MAPA, na delegacia local no estado de Santa Catarina. O movimento conseguiu constituir uma rede de apoios técnico-científico importante para fortalecer sua iniciativa do ponto de vista institucional, operacional e político.

É nesse contexto de trocas e aprendizagens que os pesquisadores iniciam um debate sobre a inclusão de sementes varietais no processo de produção de sementes na medida em que a ideia inicial do movimento era trabalhar exclusivamente com as sementes crioulas dos camponeses e produção agroecológica. $\mathrm{O}$ argumento dos pesquisadores era de que muitas dessas variedades que a pesquisa dispõe nos seus bancos de germoplasma (ex-situ) é fruto do melhoramento participativo realizado com os próprios camponeses em seus ambientes e que são recursos potenciais, inclusive, já avaliados por camponeses, para serem incluídos em programas de produção massiva. Nessa medida, o movimento delibera em reuniões sobre a inclusão das sementes varietais dos programas públicos de pesquisa - da Embrapa, Epagri, IAPAR, Instituto Agronômico e Fepagro/RS - no rol das sementes a serem produzidas.

Essa decisão teve repercussões no processo, na medida em que amplia o espectro de ação da própria comercialização e estreita as relações do movimento com a pesquisa pública e a universidade. Fernandes, G. (2017) descreve como esse processo influenciou a formatação do eixo sementes na Planapo e incorporou as sementes varietais da pesquisa pública no âmbito deste plano em decorrência da experiência do MPA. Por outro lado, o acesso a esses recursos têm custos financeiros adicionais na medida em que essas empresas estão organizadas neste setor com relações contratuais em formato similares aos de empresas privadas.

Além disso, nem todos os atores do sistema público, sejam universidades ou empresas de pesquisa, acolhem as demandas do movimento da mesma forma, há ainda no país muito preconceito em atender as reivindicações dos camponeses organizados por suas representações, seja por meio do movimento social ou por representações de classe, os sindicatos. Ainda que nesse período, que compreende os governos Lula (2003-2010) e Dilma Rousseff (2010-2016), algumas posturas de não aceitação/rejeição tenham se tornado menos explícitas. E a justificativa que se utiliza é uma diferenciação entre questões técnicas e políticas como se houvesse uma separação estanque desses universos e, sobretudo, que os movimentos sociais sejam incapazes de formatarem, elaborarem e constituírem demandas e resoluções técnicas. 
A percepção de alguns dirigentes é que havia uma desconfiança que o movimento e a cooperativa não possuíssem a experiência para realizar a tarefa de produzir dentro dos padrões técnicos e legais exigidos pelo MAPA. Assim, os camponeses recebiam visitas frequentes nos campos e na UBS para a vistoria dos procedimentos. No final, comentam os camponeses e os técnicos ligados à cooperativa, os técnicos das instituições saíam satisfeitos que os camponeses estavam utilizando as variedades da pesquisa pública.

A empresa ou instituto de pesquisa e a cooperativa realizam um contrato, onde há o fornecimento do material genético para a cooperativa que se compromete a manter e reproduzir a qualidade das sementes. A cooperativa paga royalties no valor de $5 \%$ sobre a expectativa de colheita, com exceção das sementes de feijão que é considerado material genético de livre acesso.

Portanto, é um contrato estritamente comercial e que recebe várias críticas do movimento por entenderem que os camponeses desenvolvem um trabalho socioambiental tanto no que toca a conservação do patrimônio genético dos camponeses, com as sementes crioulas, quanto com as variedades das empresas pública de pesquisa ao permitirem o uso por vários camponeses em diferentes ecossistemas. 


\subsubsection{Fomento - Infraestrutura e Logística}

Figura 6 - Fotografia da cooperativa Oestebio, no município de São Miguel do Oeste-SC-Brasil. Registro realizado por ocasião do trabalho de campo, pela autora, em maio de 2016.

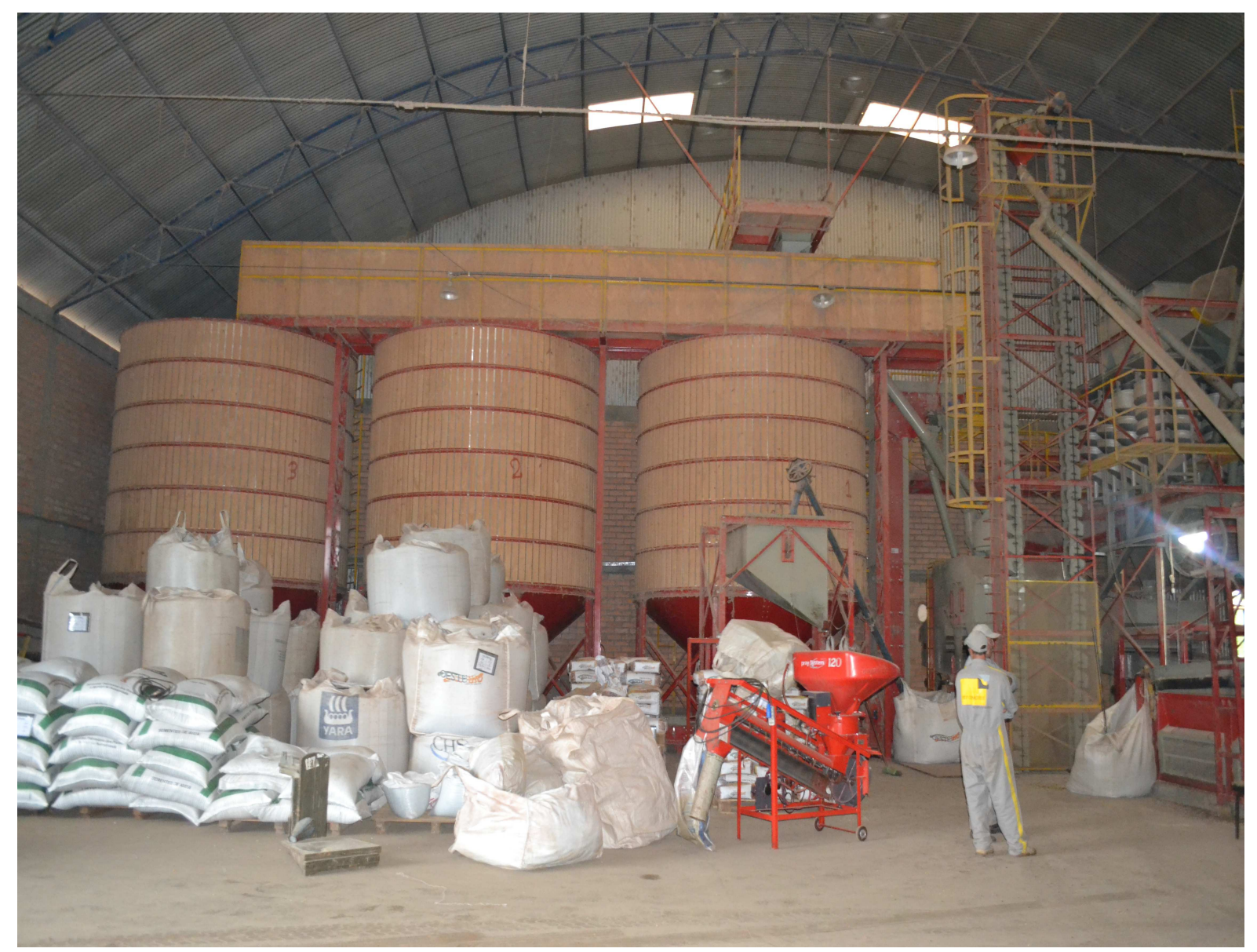

Com a decisão do projeto de massificação, houve a necessidade de construção de uma usina de beneficiamento. A experiência vinha mostrando que para a construção de uma estratégia de massificação numa perspectiva territorial, o armazenamento realizado nas propriedades dos camponeses e mesmo nas casas/bancos de armazenamento de sementes existentes não seria suficiente para a quantidade de sementes requeridas. Além disso, envolvia questões de beneficiamento, classificação e toda a logística numa produção em escala maior como estava sendo delineada.

Para a construção da usina necessitou-se de um volume de recursos que o movimento conseguiu articular por meio do apoio tanto do poder local - prefeitura, parlamentares, instituições técnicas e da extensão rural do Estado, a Epagri, Embrapa e UFSC - quanto no âmbito federal por meio dos ministérios, no caso o MDA, além de apoio de movimento sociais como o MST. Inicialmente, o movimento apresentou um projeto para o MDA para a 
construção da usina de beneficiamento. Mas tarde, por meio de várias articulações que envolveram entre outros formatos, emendas parlamentares e recursos de fomento conseguiram acessar recursos não reembolsáveis com envolvimento e parceria da prefeitura do município de São Miguel do Oeste e o MST.

O projeto inicial era construir a usina no município de Anchieta, mas o volume de recursos necessários para a contrapartida, no valor de $20 \%$ do total dos recursos mobilizados, que deveria ser ofertada pela prefeitura, inviabilizou a instalação da usina nesse município. Após conseguirem os recursos para a construção da usina foram necessários dois anos, 2009 a 2011, para o projeto da usina sair do papel e tornar-se realidade. Assim, a UBS foi instalada no município de São Miguel do Oeste numa parceria entre a prefeitura e a Cooperoeste cooperativa ligada ao MST - que cedeu o terreno onde está em funcionamento a usina. $\mathrm{O}$ projeto para a instalação técnica da usina foi desenhado pela empresa de máquinas (Silomax), seguindo padrões convencionais, com capacidade de armazenamento estimada em 5,4 milhões de grãos (a granel) nos 3 silos e 3 milhões de kg de sementes ensacadas no galpão de 60x25x6m (MAZURKIÉVICZ, 2011).

Durante esse período, no ano de 2007, o movimento criou a cooperativa de produção, a Oestebio, objetivando atender as demandas do MPA, não apenas com relação às sementes, mas sobretudo, para trabalhar com a transição agroecológica com foco na produção de sementes e na comercialização por meio dos mercados institucionais como o PAA e a merenda escolar (PNAE). A Oestebio abrange os três estados do sul do país, Paraná, Santa Catarina e Rio Grande do Sul. É por meio da Oestebio que a usina é operada e acontece toda a coordenação técnica do processo de produção de sementes no que tange aos processos de produção, beneficiamento, armazenamento, comercialização e distribuição de sementes crioulas e varietais do projeto nacional de produção de sementes do MPA. A cooperativa tem registro no MAPA como produtor de sementes registradas e fiscalizadas e está inscrita no RENASEM para produzir, beneficiar e comercializar sementes fiscalizadas nas categorias S1 e S2.

No percurso de capacitação e formação esse processo de como operar a usina do ponto de vista legal e de registro no MAPA teve o assessoramento desse grupo de pesquisadores e colaboradores, já descrito anteriormente, e que foi importante para a apropriação de conhecimentos, legalização e reconhecimento do projeto do MPA. Os camponeses não estavam acostumados a uma burocracia cotidiana que obrigava a documentar todo o percurso 
de produção da semente ${ }^{83}$, desde a origem da fonte genética até o destino final da semente produzida. Nesse processo, tiveram que deslocar pessoas para realizar esta atividade de rastreamento ${ }^{84} \mathrm{e}$ dedicar-se quase que integralmente a realização dessa etapa do trabalho com registros e envio de informações para o ministério. Muitos dos filhos dos camponeses foram integrados a essas novas dinâmicas que geraram novos postos de trabalho na cooperativa e nas comunidades.

\subsubsection{Programa de Aquisição de Alimentos - PAA}

Figura 7 - Sementes ensacadas para comercialização no Programa de Aquisição de Alimentos-PAA do governo federal, armazenadas no galpão da cooperativa Oestebio, no município de São Miguel do Oeste-SC-Brasil. Registro realizado pela autora durante o trabalho de campo, em maio de 2016.

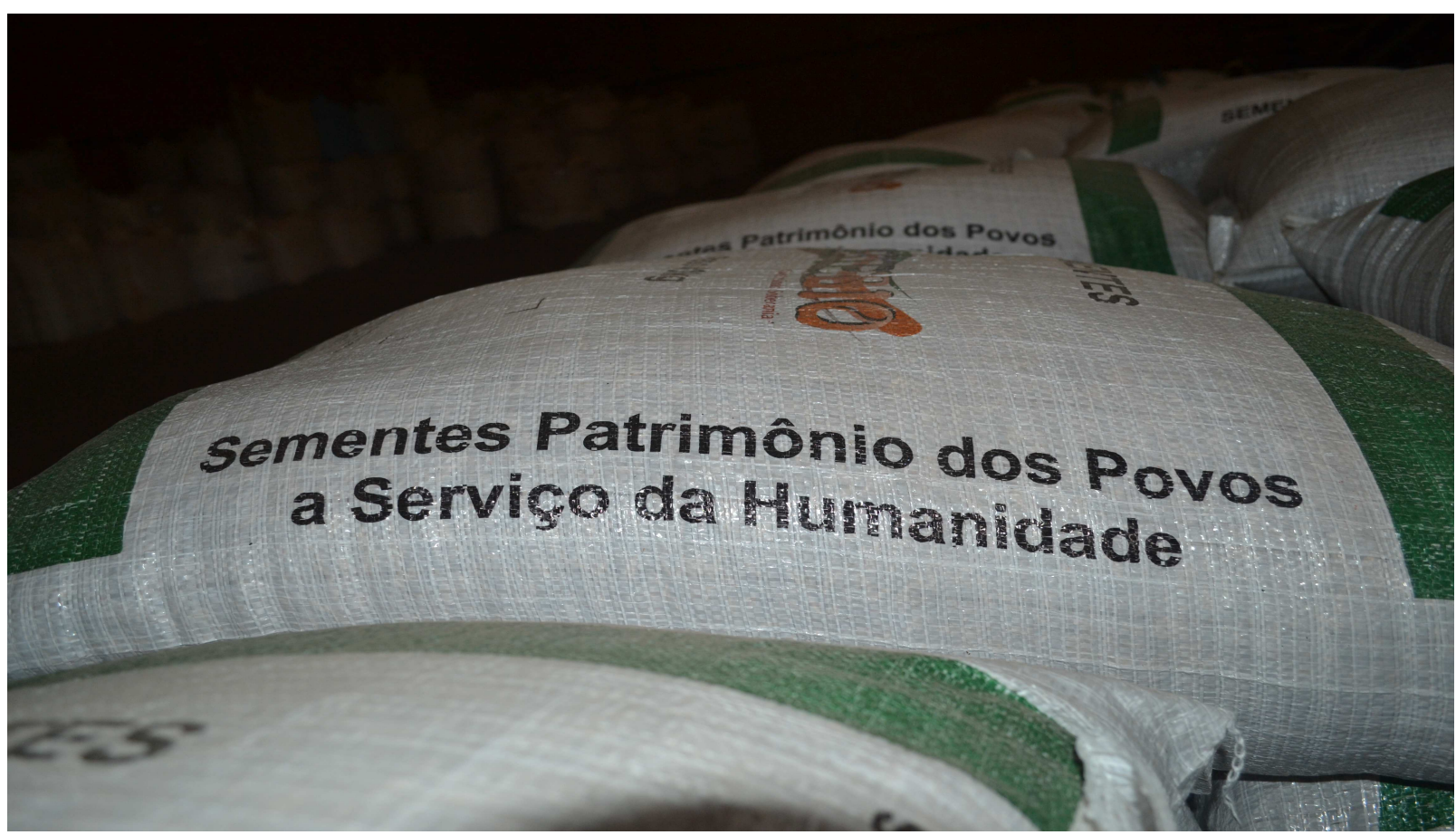

A incorporação das demandas dos movimentos sociais nas políticas públicas brasileiras para o meio rural, no último período, tiveram diferentes formatos e direções e que já estavam presentes no documento do que seria o plano de governo de Luiz Inácio Lula da Silva, "Vida Digna no Campo", no item sobre programa de fortalecimento da agricultura familiar e dos assentamentos da reforma agrária, constava: "Estimular compra de produtos da

\footnotetext{
${ }^{83}$ Como descreve Santilli (2009) as seguintes operações devem ser informadas ao MAPA: inscrição dos campos de produção de sementes - áreas dos produtores; identificação da semente genética; anexar a autorização do obtentor; apresentar os mapas de produção e comercialização; manter em seus registros o projeto técnico de produção, laudos de vistoria de campo; as informações do beneficiamento e o termo de conformidade e a certificação das sementes.

${ }^{84}$ Ver mais detalhes em BRASIL, 2011, no Guia de inspeção para produção de sementes.
} 
agroindústria familiar local e dos assentamentos via demanda institucional, como merenda escolar, hospitais públicos, restaurantes populares" (VIDA DIGNA NO CAMPO, 2002, pg. 20).

Algumas que já existiam, como o PRONAF, foram ampliadas para incorporar o maior número de camponeses possível em diferentes estratos; outras foram reformuladas como às de assistência técnica e extensão rural, incluindo às organizações sociais como prestadoras desse serviço; e outras tiveram que ser inventadas e, o PAA, talvez, seja uma das mais festejadas pelos camponeses porque abriu a possibilidade de vender o seu produto diretamente ao mercado sem intermediários.

Essa engenhosa invenção foi, inicialmente, operada por diferentes organizações sociais espalhadas pelo país no âmbito local - associações, cooperativas, sindicatos, etc envolvendo diferentes institucionalidades em nível federal entre elas a CONAB/MAPA, que operava o sistema de aquisições e distribuição - o MDS e MDA responsáveis pelos recursos orçamentários e suas instâncias estaduais faziam chegar os produtos no conjunto da rede de equipamentos públicos que recebiam os produtos, nos municípios do país.

O PAA foi instituído pela lei n. 10.696, de 2 de julho de 2003 e criado pelo Ministério Extraordinário de Segurança Alimentar e Combate a Fome (MESA) e desenvolvido em colaboração com governos municipais, estaduais e organizações sociais, operacionalizado pela CONAB. O Programa atua em duas frentes, objetivando apoiar a comercialização dos produtos da agricultura familiar e camponesa e entregar/doar esses produtos aos equipamentos públicos que atendem a segurança alimentar e nutricional, as populações fragilizadas e para a formação de estoques. Assim, faz a ponte entre a agricultura camponesa e as populações em situações de insegurança alimentar e nutricional.

O programa está dividido em seis modalidades, as quais apresentam distinções quanto à destinação e valores envolvidos nas operações. Fazem parte das modalidades do PAA: Compra com Doação Simultânea-CDS, Compra Direta-CD, PAA Leite, Formação de Estoques-FE, Compras Institucionais-CI e Aquisição de Sementes (GRISA; PORTO 2015).

A modalidade de Aquisição de Sementes que nos interessa, em particular - inclui sementes, mudas e materiais propagativos - na medida em que está intrinsicamente vinculada à experiência do MPA. Apenas em 2014, após 10 anos de operação do PAA, é criada a modalidade própria para a comercialização de sementes, o PAA Sementes. Eleva-se o teto mínimo da operação que, por exemplo, no último período alcançou $\mathrm{R} \$ 16.000,00$ enquanto a comercialização de alimentos operava com o limite de R \$ 8.500,00, reconhecendo que há um custo maior na produção de sementes, portanto, há que se remunerar de forma diferenciada e 
justa. Além disso, determina que 5\% do orçamento do PAA destinem-se a compra de sementes.

Esse processo foi uma elaboração de vários atores sociais e organizações da sociedade civil que construíram as condições de no desenrolar da política aprimorá-la, nos seus diferentes fóruns de discussão como o Grupo Gestor e o comitê consultivo. Muitos desses sujeitos e organizações participavam de outros espaços que, consistentemente, reivindicavam um tratamento diferenciado ao tema das sementes crioulas tais como os fóruns da Economia Solidária, CONSEA, e, sobretudo na CNAPO, quando se elabora a PLANAPO, já referida anteriormente. Então, havia todo um ambiente que consubstanciou o debate em torno da questão e ela foi tomando formato e grandeza. E é na CNAPO que se apresenta a sugestão de criação do PAA Sementes.

Além disso, os gestores que passaram na pasta da CONAB, nos últimos anos, tinham um certo acúmulo no debate internacional sobre o tema da biodiversidade, erosão genética, patrimônio genético, entre outros que consolidavam teoricamente o debate de ampliação da oferta de sementes crioulas no interior das políticas públicas. Portanto, tinham sensibilidade e abertura para redesenhar os formatos de operação e gestão da política, respeitando a institucionalidade e os marcos regulatórios.

Assim, essa modalidade é criada pelo Decreto $\mathrm{n}^{\circ}$ 8.293/2014 e permitirá que os camponeses possam comercializar anualmente valores até $\mathrm{R} \$ 16.000$ por meio do DAP ${ }^{85}$ (Declaração de Aptidão Agrícola ao PRONAF) e as organizações sociais como a cooperativa Oestebio, por exemplo, valores até R\$ 6.000.000,00, anualmente (CONAB, 2015).

Nas ações de comercialização com o PAA ${ }^{86}$ que apresenta diferentes normatizações e exigências para o processo de realização de compras institucionais ocorreu o mesmo processo intenso de aprendizagens. A primeira experiência com a comercialização de sementes do movimento veio com o MPA de Góias, por meio da associação estadual. No estado de Santa Catarina, as primeiras comercializações ocorreram por meio da associação estadual do movimento e envolveu a produção de aproximadamente 12 toneladas de sementes, as quais foram distribuídas nas feiras de milho crioulo. Mas foi a partir de 2010/2011, que a demanda

\footnotetext{
${ }^{85}$ A obrigatoriedade da DAP, para o caso das sementes, é tanto para quem fornece e para aqueles que recebem. Entre as entidades que são aptas para demandar sementes estão: MDA, INCRA, FUNAI, FCP (Fundação Cultural Palmares), ICMBio e governos estaduais. Além dessa regulamentação, estão listados como públicos prioritários: o público do CadÚnico, mulheres, assentados, indigenas, quilombolas, público do PBSM (Programa Brasil sem Miséria) e aqueles da PLANAPO (CONAB, 2015).

${ }^{86}$ No sítio da CONAB/MAPA encontra-se toda a descrição do processo e orientações que deverão ser obedecidas no atendimento das normas que regulamentam o programa, do ponto de vista dos agentes envolvidos, camponeses, suas organizações e demais instituições, demandantes e ofertantes, no Manual de Operações da CONAB (http://www.conab.gov.br/conabweb/moc.php). Último acesso em 03.12.2017.
} 
começa a crescer e a experiência do MPA/SC torna-se nacionalmente visível no seu pioneirismo no processo de produção massiva e se consolida no processo com a instalação da UBS e a constituição da Oestebio, conforme podem ser observado nos dados das tabelas 2, 3 e 4 que corresponde ao número de camponeses envolvidos, volumes produzidos e comercializados, no período de 2009 a 2014 (PAADATA/CONAB, 201587).

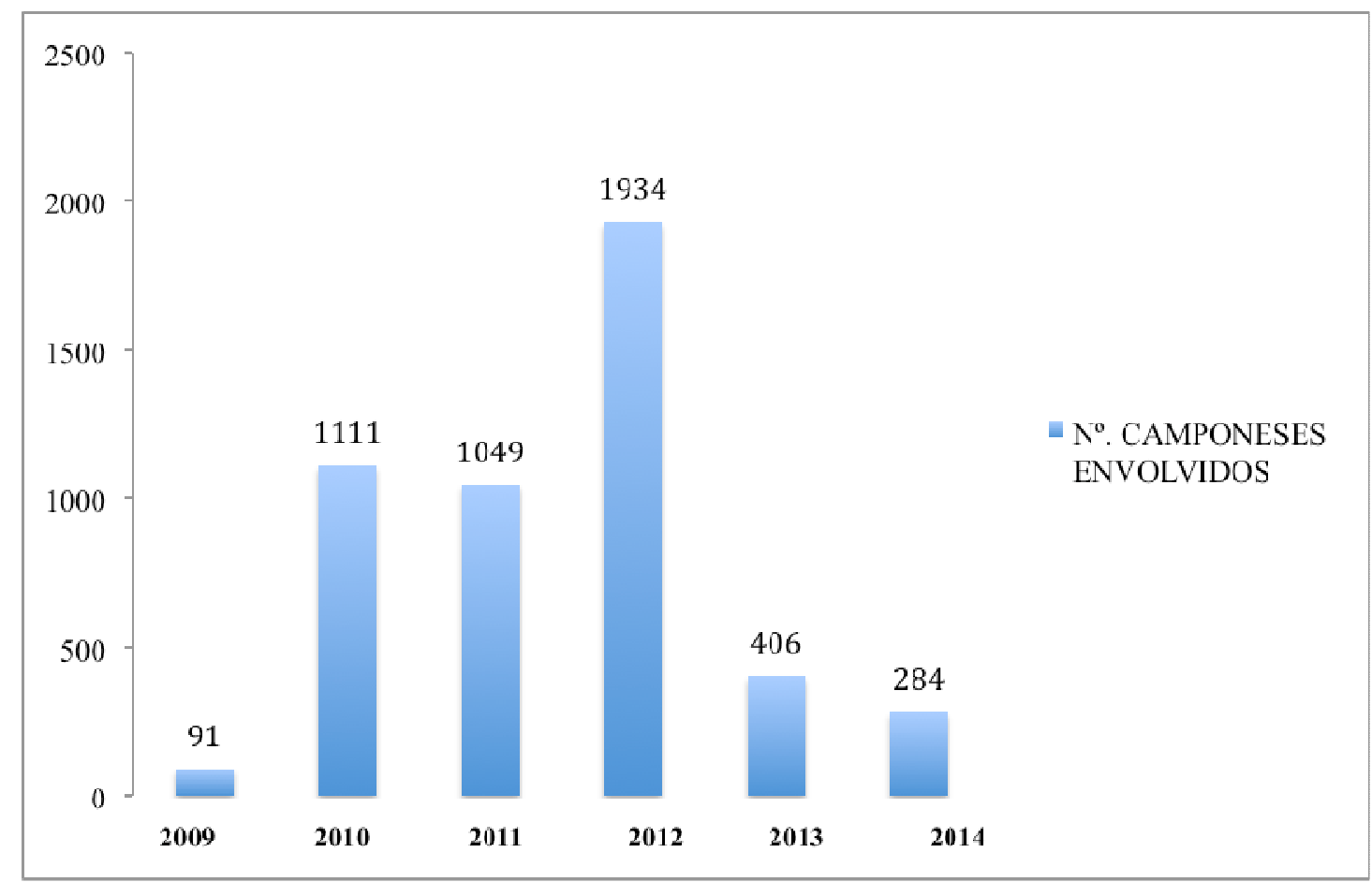

Tabela 2 - Quantidade de camponeses envolvidos no período de 2009 a 2014 na produção desementes da Oestebio.

Fonte: PAADATA/CONAB/2015.

\footnotetext{
${ }^{87}$ Base de dados fornecidos pela CONAB, em 2015.
} 


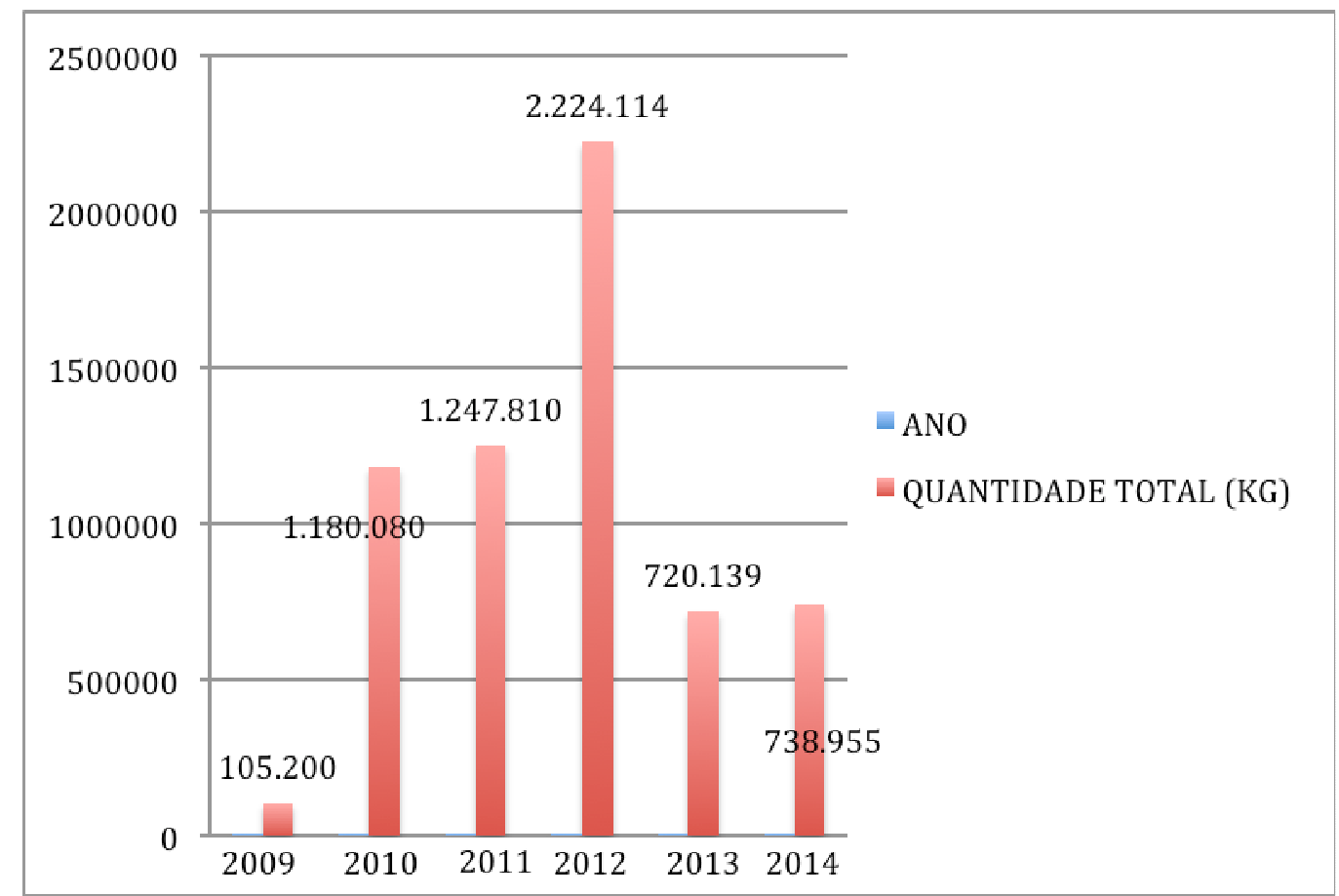

Tabela 3 - Quantidades de sementes comercializadas para o PAA/CONAB, no período de 2009 a 2014.

Fonte: PAADATA/CONAB/2015.

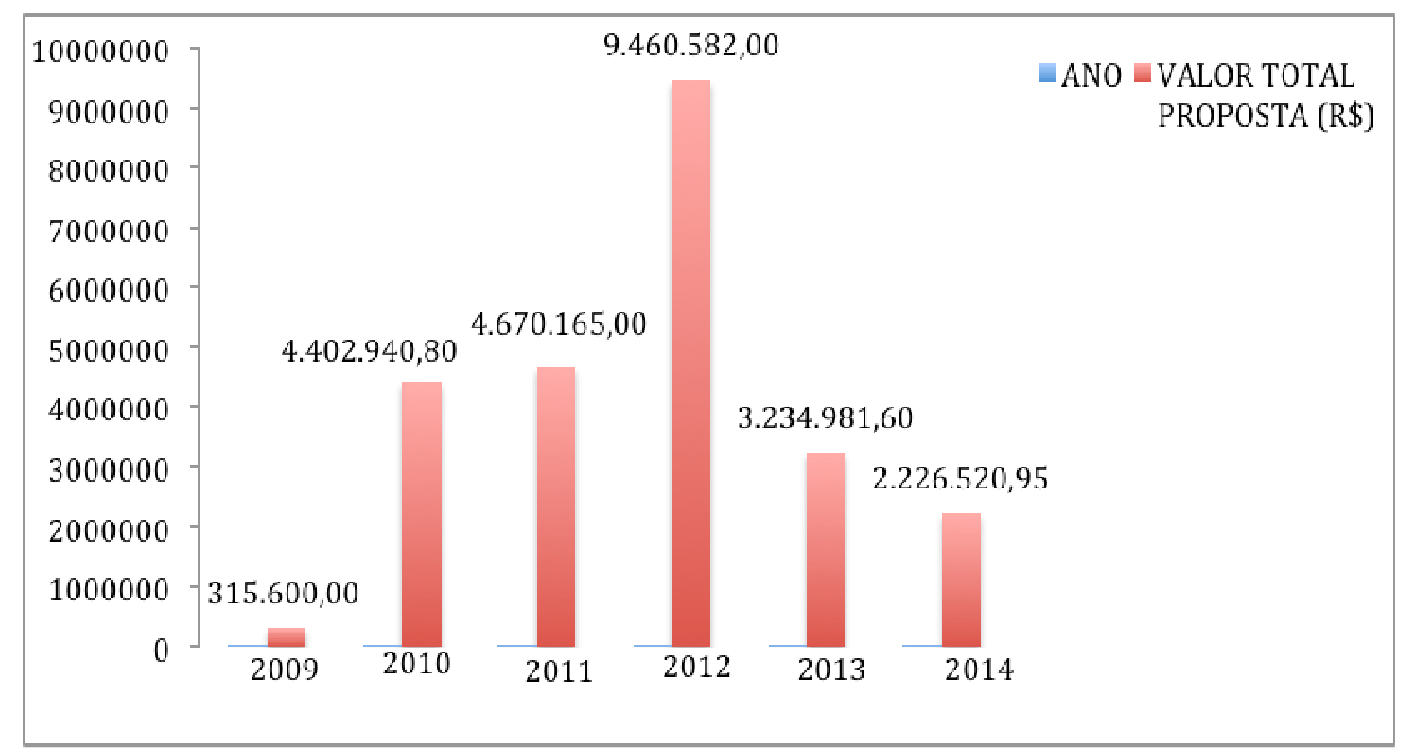

Tabela 4 - Volume de recursos envolvidos na comercialização com o PAA/CONAB, no período de 2009 a 2014.

Fonte: PAADATA/CONAB/2015.

As quedas bruscas da comercialização de sementes com a Conab, nos períodos de 2013 e 2014, podem ser explicadas pelas mudanças na operacionalização do PAA nos anos de 2012 e 2013 em virtude do redesenho da política (VALADARES e SOUZA, 2015; TRICHES e GRISA, 2015). Tais modificações dizem respeito as unidades executoras como a Conab, por 
exemplo, que sofreu redução drástica na sua operacionalização comparada aos anos anteriores, em especial, o ano de 2012, considerado por Valadares e Souza (2015) o auge das operações executada por essa companhia. Segundo esses autores essa redução atingiu o programa como um todo, representado pela baixa participação dos camponeses na oferta de produtos - da ordem de 49,8\% menor - quanto no volume de recursos envolvidos - neste caso $47,2 \%$ menor - quando comparado com o período anterior. No total, as operações coordenadas pela Conab nesse período 2012-2013 diminuiu de 70\% para 51\% do valor total executado (VALADARES e SOUZA, 2015).

Esse redesenho foi protagonizado pela redefinição da atuação do MDS no programa que significou a diminuição da atuação das organizações sociais dos camponeses na operacionalização dos convênios que foram substituídos pelos termos de adesão celebrados entre esse ministério e os estados e municípios, privilegiando as formas de participação individualizada dos camponeses e retirando o protagonismo de suas organizações coletivas (VALADARES e SOUZA, 2015).

De acordo com Triches e Grisa (2015) o processo de criminalização dos camponeses e suas organizações por meio da operação da polícia federal denominada de Operação AgroFantasma ${ }^{88}$ colaborou na formação de uma opinião pública negativa, especialmente pela atuação da mídia, a cerca do programa, desvirtuando o rico processo de aprendizagens que vinha sendo constituído por essas organizações e o próprio Estado do qual o processo que ora narro compõe uma dessas experiências.

Os processos de comercialização operados pela cooperativa por meio do PAA executado pela CONAB/MAPA com recursos do MDS e MDA - também favoreceram intensos aprendizados, pois exigiu a aquisição de conhecimentos na área da utilização de recursos públicos e gestão. As formas de comprovações exigidas, tanto por parte dos camponeses que produzem, quanto da própria cooperativa que teve que realizar diversas adequações no decorrer do processo, a fim de atender as exigências dos editais de compras públicas, dos diversos sistemas de gestão envolvidos, entre outros, tornou-se um locus de produção de conhecimentos. E foi um processo recíproco de aprendizagens na medida em que é uma experiência que está se constituindo, o PAA tornou-se um rico laboratório de inovações sociais no qual o movimento social operou junto com o governo federal. A Oestebio não é

\footnotetext{
${ }^{88}$ A operação Agro-Fantasma foi desencadeada no período de 2009 e 2013 no estado do Paraná, visando apurar presumidos desvios no PAA, resultando em diversos processos judiciais, envolvendo funcionários vinculados a Conab e prisões indevidas de camponeses, decretadas pelo juiz federal Sergio Moro, em Curitiba. Após mais de três anos, os camponeses foram absolvidos (http://terradedireitos.org.br/noticias/noticias/agricultores-saoinocentados-de-acusacao-de-desvios-no-programa-de-aquisicao-de-alimentos/22636).
} 
apenas uma dessas experiências, mas colaborou efetivamente na criação de uma das linhas específicas que surgiria depois, o PAA Sementes.

O tema das sementes sempre esteve presente no interior das políticas públicas, como por exemplo, no Plano Safra, no Pronaf, na assistência técnica entre outras, demonstrando sua importância no debate seja sobre segurança alimentar seja sobre agroecologia e produção orgânica. Então, no PAA ele iniciou timidamente e foi realizado, por um período, por meio de uma adaptação por dentro das modalidades existentes.

Há um reconhecimento por parte do movimento que o excesso de burocracia e formatos exigidos expressa o desconhecimento da cartografia (espaço geográfico) do meio rural. É uma burocracia de escritório, cujos tempos e formatos são fáceis de operacionalizar desse lugar, não na vida real do campo brasileiro com suas condições ambientais e materiais reais. Não importa se é verão ou inverno, o tempo previsto é o mesmo. Não importa o número de camponeses envolvidos, o raio de distância que os separam. Em uma rede de multiplicadores, envolvendo mais de 1000 camponeses, espalhada num território que envolve várias microrregiões, em um único estado, a exigência de coleta de assinaturas em lista única, num curto espaço de tempo, é desconsiderar qual a realidade que se vive no Brasil profundo. Essa forma de exigência onerou sobremaneira a operação da cooperativa, mesmo reunindo um pequeno grupo de 10 ou 15 camponeses, o custo de um deslocamento para coleta de assinaturas, seja para reunir o grupo na cooperativa, seja um técnico percorrendo as propriedades, não sensibiliza quem deveria considerar as realidades diversas neste enorme território que é o Brasil.

Ainda assim, o PAA representou o principal mercado operado pela cooperativa e um dos principais incentivos para o ingresso dos camponeses na rede de multiplicadores, na medida em que remunerava os produtos, no caso as sementes, com valores acima dos praticados no mercado, justamente, por reconhecer o esforço dispendido na produção de sementes. Assim, sementes de milho foram comercializadas com valores acima (30\%) do valor do grão de milho convencional transacionado no mercado comum, no período de 2009 a 2015. O PAA permite que os camponeses trabalhem com previsibilidade de venda, o que só é possível quando eles estão integrados nas agroindústrias do fumo, leite, suínos ou aves, nessa região, e muitas vezes, sobrando muito pouco depois que os custos de produção são descontados ou ainda, quando em situações mais frágeis, ficam endividados para a próxima safra.

Dessa forma, o mercado institucional de sementes tornou-se um importante instrumento para os camponeses do ponto de vista econômico e é considerado pelo 
movimento social uma das principais políticas públicas gestadas nesse período, uma reivindicação histórica dos camponeses na luta contra a desvalorização de seus produtos pelos atravessadores. Nos diálogos das entrevistas de campo, a narrativa de que o PAA foi importante não apenas na dinamização da economia local, mas sobretudo, colaborou no empoderamento das famílias camponesas, no fortalecimento do cooperativismo, especialmente, no âmbito da gestão do empreendimento, na relação com a coisa pública, com os recursos materiais e humanos e um fortíssimo processo de formação e qualificação dos dirigentes, técnicos, gestores e camponeses ligados ao movimento. É um salto de qualidade. Vejamos o depoimento de um dos entrevistados:

[...] ela é a melhor política pública para a agricultura camponesa que o governo federal desenvolveu nos últimos anos. Não desmerecendo nenhuma outra porque eu acho que elas são complementares, mas diante da dinâmica da agricultura camponesa, o PAA, era o melhor instrumento, a melhor ferramenta, a melhor política pública sem sombra de dúvida que foi desenvolvida nos últimos anos. Porque ele ajudava na comercialização, na logística, no capital de giro, tudo o que um projeto precisa pra dá certo, o PAA tinha condições de ajudar né...Uma família que só cuidou da porteira pra dentro com o PAA ele cuidou da porteira, mas cuidou da porteira pra fora também. Porque ele aprendeu a fazer comercialização direta, sem o atravessador. Então foi pra nós uma das melhores experiências que a gente teve. Nem o PRONAF cumpriu com esse trabalho, com esse papel que é uma política importante. Nem o PRONAF teve o papel preponderante como o PAA teve no desenvolvimento da agricultura camponesa (Entrevista, $\left.2016^{89}\right)$.

Na perspectiva da soberania territorial o depoimento acima reflete a possibilidade de desenho de uma estratégia coletiva por meio desta política, na medida em que a política não alcança apenas o camponês individualmente, ela potencializa a ação coletiva das organizações sociais e por isso mesmo o MPA conseguiu operar um dos maiores desafios dos governos que é fazer as políticas se conversarem, dialogarem, se complementarem, atuarem em sintonia no território. Esse foi um papel desempenhado pelo movimento. Um ator essencial que fazia as diferentes pontes nas diversas escalas, local, estadual e nacional. Tornou instrumentos complexos em ações práticas e cotidianas com repercussões financeiras e políticas para os camponeses.

Nesse processo, o movimento percebeu que havia uma demanda crescente por sementes crioulas e varietais não apenas por parte das organizações dos agricultores, mas pelos governos estaduais para atender populações do campo, desde camponeses a povos indígenas e populações tradicionais, sobretudo, aquelas afetadas por secas e enchentes,

\footnotetext{
${ }^{89}$ Esta entrevista foi realizada, em 01 de dezembro de 2016, após o golpe institucional ocorrido no país e, já havia um sentimento de que as políticas não teriam continuidade.
} 
persistentes ou ocasionais, que nesse período ocorreram no país não apenas na região nordeste, mas na própria região oeste de Santa Catarina (ESPÍNDOLA e NODARI, 2012).

A experiência de massificação tornou-se, ao longo do período, um espaço importante de trocas de experiências entre as organizações sociais que passaram a visitá-los e constituírem processos similares em diferentes regiões do país, como por exemplo, o MST do estado do Paraná e os próprios camponeses ligados ao MPA de outros estados como Rio Grande do Sul e Bahia. Além disso, o reconhecimento do próprio estado brasileiro por meio de visitas de parlamentares, de membros da CTNBio, de diferentes órgãos governamentais, delegações internacionais e governantes de outros estados da federação. Esse processo de visibilidade foi muito importante porque garantiu a valorização da experiência e o reconhecimento público do processo.

A experiência do MPA e de outras organizações sociais foi fundante para as modificações que foram operadas no PAA com relação às modalidades de funcionamento e a criação da modalidade de Aquisição de Sementes. Debatido exaustivamente com os dois ministérios envolvidos no processo, o MDA e o MDS, com visitas in loco de técnicos e gestores da política pública nas experiências em curso para averiguar as adequações necessárias, resultaram em 2014 com a criação da modalidade já referida inicialmente neste item. O PAA torna-se efetivamente uma política pública alimentada a partir das experimentações sociais. Certamente, o exercício político nos conselhos nacionais colaborou em dar maior visibilidade a argumentação do movimento.

Nessa medida, a estratégia da soberania genética conseguiu não apenas diminuir a dependência das sementes transgênicas, mas também a insegurança alimentar, na medida em que as sementes aí produzidas foram distribuídas por meio do PAA às famílias e populações fragilizadas, em especial no Nordeste, por ocasião da grande seca nessa região nos anos de 2012 e 2013.

No entanto, o mercado de compras públicas isoladamente não é suficiente para fazer uma coordenação do processo maior de disputa de modelos de agricultura, tendo a semente crioula ou mesmo a VPA como um vetor do processo, ainda que possa ser um estímulo inicial, na medida em que este desafio dever ter um envolvimento estratégico do estado brasileiro, numa formulação mais clara por meio de uma política pública própria com metas distribuídas no território para reordenamento da paisagem agrícola livre de transgênicos, como pode ser observado atualmente no estado do Mato Grosso e o retorno à produção da soja convencional, ainda que represente a continuidade dos monocultivos. 
Por um lado, há o reconhecimento que nesse período, ainda que as sementes crioulas representem apenas traços no percentual das sementes que estão sendo cultivadas na agricultura brasileira atual, especialmente, no que se refere às commodities e as culturas onde os camponeses estão integrados nas agroindústrias como leite, suínos e aves, como é o caso, particularmente, no estado catarinense, houve um esforço não só por parte do governo, mas sobretudo, das organizações sociais para recuperar a soberania genética no país. Por outro lado, há uma infinita e complexa burocracia estatal, especialmente, pelos órgãos de controle do uso de recursos públicos que, pelos desdobramentos de algumas operações, tem pouco conhecimento sobre o funcionamento da atividade da agricultura, bem como das condições estruturais com que vivem os camponeses nesse país. E esta forma de operar não é exclusiva desses órgãos do Estado brasileiro, mas em grande medida, da burocracia estatal no país, como já relatado anteriormente.

Para avançar nessa mudança de cenário será preciso diversas mudanças, em particular, transformações políticas profundas que impactem a correlação de forças atuais e desencadeiem modificações institucionais, porque hodiernamente não há correlações de forças e interesses suficientes para tal. As agendas produzidas nesses espaços, seja na pesquisa até alcançar o camponês no campo, estão intrinsecamente interligadas, representa uma cadeia. Até aqui houve um consenso da importância do tema sementes - a recuperação das crioulas e sua manutenção - diferiram as formas de implementação, inclusive, no interior do movimento social.

Outra questão que se levanta é a produção da dependência dos mercados institucionais para a comercialização e distribuição das sementes crioulas e as VPAs que podem estar ligadas à ausência de uma política de comunicação para dialogar com camponeses que não estão na base dos movimentos sociais, por exemplo. Porém, muito importante salientar que essa política não pode ser responsabilidade exclusiva dos movimentos sociais ou dos camponeses isoladamente, na medida em que envolve soberania genética do país, como também tornar utilizáveis os produtos da pesquisa pública. Como foi mostrado até aqui, a questão da soberania genética é uma questão socioambiental e de soberania alimentar, portanto, deve ser tratada como questão nacional.

\subsubsection{Seguro da Agricultura Familiar - SEAF/PROAGRO MAIS}

Entre outros desafios para a consolidação da rede de multiplicadores estava o acesso ao seguro agrícola. O Proagro - Programa de Garantia da Atividade Agropecuária - é 
considerado a primeira política do Estado brasileiro direcionado ao seguro agrícola, nasceu no ano de 1973, no conjunto das políticas de crédito, extensão rural, pesquisa, financiamento, entre outras, no contexto do pacote da revolução verde. O mesmo sofreu uma reformulação em 1991 na tentativa de ampliação do número de segurados (VASCONCELOS, 2012). Segundo Vasconcelos (2012) o Proagro, durante seu período de vigência, serviu para assegurar os bancos e não propriamente as safras perdidas pelos camponeses devido às intempéries climáticas, na medida em que asseguravam apenas aqueles camponeses e produtores que tinham acesso ao crédito.

Atualmente, há duas modalidades do Proagro, o tradicional, destinado as operações do agronegócio e operações do Pronaf que não se enquadram no Proagro Mais, que é a segunda modalidade e dá cobertura aos financiamentos operados com recursos do Pronaf Custeio aos camponeses e agricultores familiares (VASCONCELOS, 2012). O Proagro Mais foi criado no primeiro período do governo Lula, em 2004, objetivando ampliar o acesso dos camponeses e agricultores familiares ao seguro agrícola. Ele foi denominado de SEAF (Seguro da Agricultura Familiar) pelo MDA, mas popularizou-se como Proagro Mais (CAPELLESSO, 2016).

Segundo Zukowski (2015) o SEAF pode ser considerado um seguro multirrisco, cobrindo uma ampla variedade de perdas - de alterações climáticas a ataques de pragas e doenças. Estruturou-se a partir de reformulações do Proagro e o funcionamento se dá por meio do Pronaf Custeio. Possui como instrumentos de controle o Zoneamento agrícola de riscos climáticos realizadas pela Embrapa e pelas recomendações de plantios divulgados pelo MAPA. O MDA, MAPA e BACEN (Banco Central) coordenam o processo e todas as orientações constam do Manual de Operações de Crédito Rural (ZUKOWSKI, 2015).

O SEAF iniciou securitizando uma cobertura de renda no valor de R\$ 1.800 reais, cobrindo sete culturas, ou seja, as commodities que provinha da experiência que o país tinha acumulado até então a partir do Proagro tradicional. Ao longo do processo, recebeu várias reclamações e reivindicações de melhoria dos movimentos sociais que foram sendo incorporadas ao sistema para adequação às realidades da agricultura familiar e camponesa. Em seus 12 anos de operação (2004-2016), cobrem 150 culturas, que são as culturas financiadas com o Pronaf Custeio e os valores dos limites de cobertura atuais são R 22.000 para culturas anuais e $\mathrm{R} \$ 40.000$ para as culturas permanentes e olerículas (SECRETARIA, 2017). Atualmente, camponeses que acessam o Pronaf Custeio aderem obrigatoriamente ao SEAF (LONDRES, 2006; CAPELLESSO, 2016). 
No processo de ampliação da rede de camponeses multiplicadores o acesso a este seguro foi considerado fundamental. Primeiro porque ainda estava muito presente, nesse período (2007-2008), a experiência que os camponeses dessa região tinham vivenciado com uma intensa estiagem. Vejamos como a descreve Zukowski (2015):

Logo no primeiro ano do seguro, a região sul do país foi atingida por uma
verdadeira catástrofe agroclimática - uma seca que se agravou até acabar
sendo a maior dos últimos 60 anos. Mais de 240 mil agricultores receberam
cobertura do seguro naquele ano. Grande parte desses agricultores já havia
sofrido perdas em anos anteriores a criação do SEAF, tinha dívidas
prorrogadas pendentes nos bancos e teria dificuldade de obter novas
prorrogações. Sem o seguro, não teriam recursos para plantar na safra
seguinte e muitos deles estariam na contingência de ter que abandonar suas
atividades rurais e vender sua propriedade para pagar as dívidas. O seguro
proveu instrumentos para administrar a situação, evitando uma grave crise
social (ZUKOWSKI, 2015, pg. 102).

Assim, o receio dos camponeses tinha bastante fundamentação porque por ocasião das safras de 2004/2005, 2005-2006, parcela desses camponeses que acessaram o Pronaf Custeio, nessa região, e usaram sementes crioulas não conseguiram acessar o seguro (SANTILLI, 2009; CAPELLESSO, 2016). Ainda, segundo a SAF - Secretaria de Agricultura Familiar/MDA, à época, avaliava-se que as mais de 40 mil solicitações de cobertura de seguro agrícola que foram desaprovadas tiveram como justificativa o uso de 'tecnologia inadequada', entre elas o uso de sementes crioulas, piratas e convencionais (LONDRES, 2006).

O debate de inclusão das sementes crioulas na cobertura do SEAF envolveu diversos movimentos sociais e ONGs e teve papel preponderante na ampliação da rede, no que tange a inclusão de novos camponeses como multiplicadores. No princípio, grande parte dos multiplicadores eram os próprios guardiões. Nesse processo, o MPA desempenhou um papel fundamental no convencimento e articulação para que se concretizasse essa inclusão das sementes crioulas no sistema do seguro, mesmo não havendo consenso sobre a questão entre os diversos atores envolvidos na discussão sobre o tema (LONDRES, 2006; FERNANDES, 2017).

Por outro lado, a própria ampliação da rede de multiplicadores exerceu uma forte pressão para que o banco fosse forçado a reconhecer que muitos camponeses estavam não apenas utilizando as sementes crioulas, mas produzindo essas sementes, como os próprios fiscais do banco constataram. Mesmo assim, havia muitos camponeses que tinham receio de plantar sementes crioulas em virtude da pressão dos agentes do banco - Banco do Brasil por que elas não eram reconhecidas nos programas de financiamento público como uma 
tecnologia ${ }^{90} /$ insumo que constava do pacote tecnológico recomendado, portanto, plantios cultivados com sementes crioulas estavam excluídos da cobertura do seguro agrícola.

Foi a persistente gestão do movimento, tanto nas agências locais do Banco do Brasil, quanto nos diversos conselhos ${ }^{91}$ onde os dirigentes do movimento atuavam em Brasília, juntamente com outros atores, que possibilitou o reconhecimento dessas sementes como um insumo válido na institucionalidade do SEAF. Esse processo é considerado pelo movimento uma conquista importante, mesmo que tenham que proceder ao registro no novo cadastro criado, o Cadastro Nacional de Cultivares Locais, Tradicionais ou Crioulas na SAF/MAD ${ }^{92}$. Isso porque representou um importante passo na consolidação da rede de multiplicadores.

A realidade dos camponeses desse estado é muito peculiar, diferentemente de outros camponeses do país, eles estão integrados nas agroindústrias citadas acima, muitos deles com acesso ao Pronaf custeio e, vivenciaram, nas últimas décadas secas intensas. O novo formato do SEAF/Proagro Mais tinha peso relevante na estratégia em curso de ampliação da rede. A capacidade de articular as várias políticas públicas disponíveis e disputá-la cotidianamente, no sentido de adequá-la a realidade camponesa dessa região, fez uma enorme diferença na capacidade de constituir a experiência e mantê-la operando, durante esse período, envolvendo um grande número de camponeses inseridos na rede.

Essa é uma região que tradicionalmente convive com verânicos e fazem com que ocorram perdas totais na produção. Além disso, as próprias empresas que comercializam sementes certificadas (híbridos e transgênicos) rotulam essas sementes de sementes piratas e difundem uma propaganda de medo sobre a não garantia do seguro pelos órgãos financiadores. Essa conquista da inclusão das sementes crioulas no rol das tecnologias descritas no formulário do banco para acessar o seguro agrícola possibilitou a ampliação e aceitação de muitos camponeses, especialmente aqueles que não eram organicamente ligada ao movimento, na rede de multiplicadores para a produção de sementes do MPA/Oestebio. Assim, essa conquista possibilitou a ampliação da rede que envolveu camponeses tanto da base do MPA quanto os demais camponeses distribuídos ao longo do território dos três estados, conforme mostra o mapa de distribuição dos campos de produção de sementes

\footnotetext{
${ }^{90}$ Nas planilhas e formulários para acesso ao financiamento do PROAGRO no Banco do Brasil havia a descrição apenas com base no pacote de tecnologias convencionais, na qual a descrição das tecnologias são descritas como de baixa tecnologia, média e alta e as sementes crioulas não constavam como insumos do pacote.

$91 \mathrm{Na}$ institucionalidade do PAA há o Conselho Gestor composto por membros da sociedade civil e do Estado. O MPA possuía um assento, cuja representação era realizada pelo dirigente nacional Charles Reginatto, de Santa Catarina, e ex-coordenador geral da Oestebio, à época desta pesquisa de campo.

${ }^{92}$ Segundo Zukowski (2015) o uso de insumos de produção própria e das sementes crioulas foram permitidas no sistema de cobertura do SEAF pela Portaria MDA nº 51/2007.
} 
abaixo. A rede de multiplicadores de sementes alcançou, no ano de 2013, o número de 3000 camponeses, nos três estados do sul do país, envolvendo 96 municípios.

Figura 8 - Mapa da rede de multiplicadores no estado de Santa Catarina, safra 2011-2012.

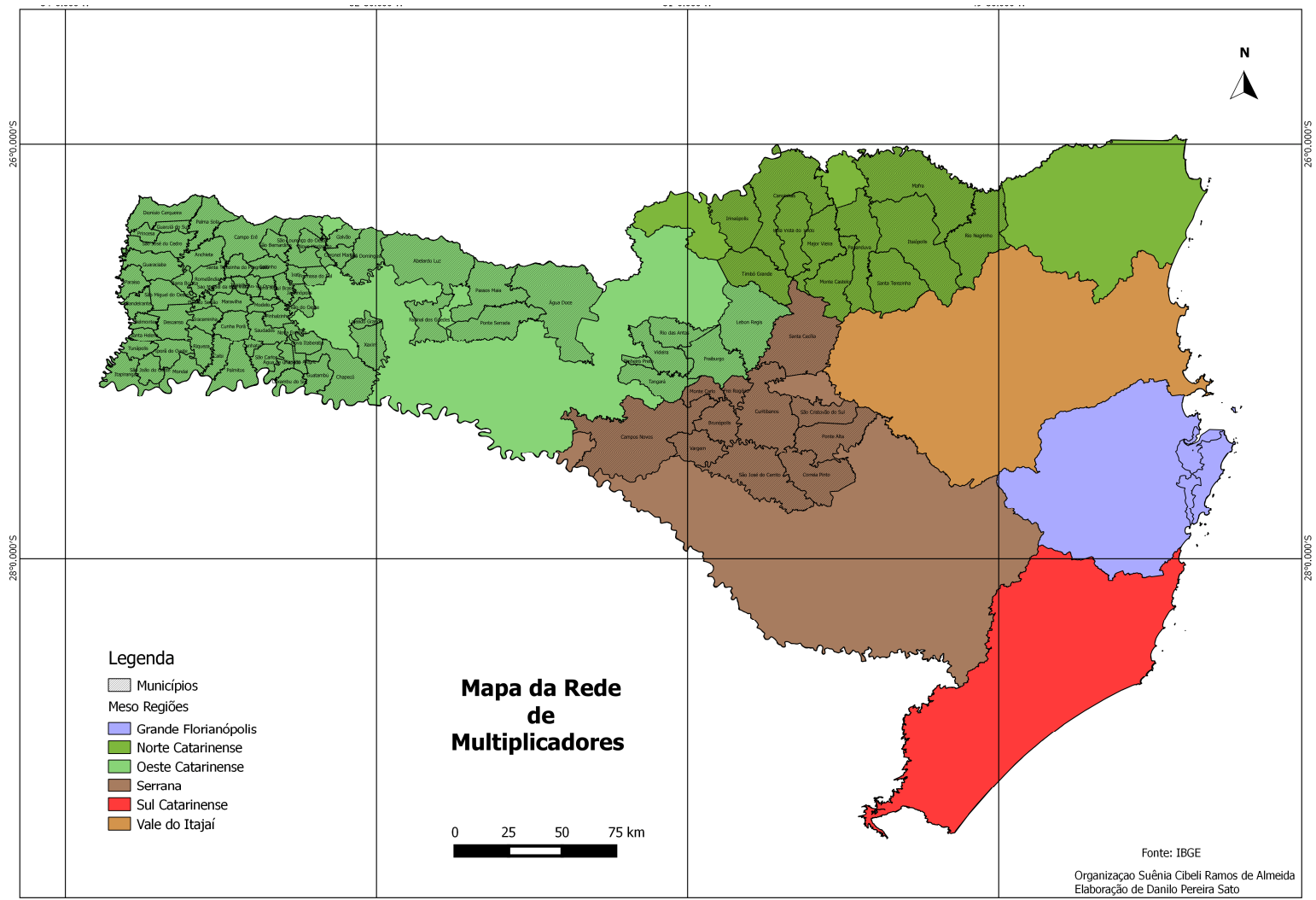

No processo, alguns camponeses da base do MPA, com várias restrições de terra e recursos financeiros foram substituídos por camponeses que possuíam acesso a melhores condições de manejo/condução dos campos de produção de sementes em conformidade com as regulamentações, em especial, na cultura do feijão, cujas exigências no controle de doenças são grandes. Mesmo recebendo assistência técnica e a semente, não conseguiram entregar sementes na qualidade exigida para comercializar. O processo de produção das sementes que foi para o campo, idealizado para ser agroecológico, embora em pequenas áreas que variam entre 0,20 a quase 5 hectares favoreceu o surgimento de pragas e doenças.

Esses camponeses não conseguiam seguir as recomendações e orientações técnicas mesmo em um sistema de transição agroecológica, em que há o uso baixo de insumos, como por exemplo, o uso de fertilizante orgânico/químicos e, mesmo agrotóxicos, e não alcançaram prosseguir na rede. O próprio movimento identifica como um ponto negativo do ponto de vista político e da própria estratégia que não conseguiu responder ainda a esses problemas que surgiram no caminho. Foi realizada gestão para a resolução de parte desses problemas com a 
elaboração de uma proposta de projeto que disponibilizasse alguma estrutura comunitária para a aquisição de máquinas, tratores e equipamentos para apoiar a continuidades desses camponeses, mas a proposta não recebeu aprovação no edital do ECOFORTE $^{93} / 2012$. Assim, que para massificar, foram obrigados a lançar mão da incorporação de outros camponeses com melhores situações financeiras para conduzir os campos de produção em conformidade com as demandas de sementes de qualidade exigidas pelo mercado.

O sistema de produção de sementes é muito exigente no que tange aos tempos e estágios de desenvolvimento da planta, especialmente, no momento da floração, pré-colheita e da colheita, ambos exigidos como momentos de inspeção pelo MAPA (BRASIL, 2011). Conforme relatado, os sistemas necessitam da realização das operações no momento em que a planta exige e as condições ambientais permitem e no caso dos camponeses que não dispõe nem de recursos materiais (máquinas e equipamentos) e mão de obra suficiente, nem de recursos financeiros para contratá-los o resultado recai sobre a qualidade das sementes que entregam. E foi o que ocorreu em algumas ocasiões, resultando na saída de alguns camponeses da rede de multiplicadores. Foi identificado esse problema, tentaram projetos para resolver a situação, mas até o momento desta pesquisa, a situação era esta aqui descrita. E eles se tornaram beneficiários, recebendo as sementes distribuídas pelo programa.

Nesse sentido, novos formatos para inclusão de multiplicadores foram elaborados com contratos formalizados numa relação comercial convencional de entrega de sementes, considerando os custos para a cooperativa. Assim, para ampliação da rede e para dar conta da demanda crescente na oferta de sementes crioulas e varietais foram incorporados camponeses dentro do território onde está espraiada a rede. A cooperativa entra com a base genética da semente, assistência técnica e a garantia de comercialização. O camponês, em contrapartida, arca com o custo da produção e se compromete em seguir as orientações técnicas e entregar a produção para a cooperativa.

Nesse novo cenário, os contratos são firmados com camponeses multiplicadores que tenham disponibilidade de área de no mínimo 1 hectare para produção de sementes e, para o caso do milho, em particular, que a área esteja distante de cultivos transgênicos para evitar contaminação. A decisão de estabelecer um limite mínimo de 1ha considerou os custos com o deslocamento para a coleta da produção de sementes; com o processo de acompanhamento da

\footnotetext{
${ }^{93}$ O Ecoforte compõe o Planapo e correponde ao financiamento de ações de estruturação, capacitação e formação com foco no setor de produção orgânica e agroecológica para o desenvolvimento territorial com recursos não reembolsáveis, financiados pela Fundação Banco do Brasil (FBB) e do Banco Nacional do Desenvolvimento Econômico e Social (BNDES) e seu primeiro edital foi lançado em 2012. Disponível em: http://www.mma.gov.br/informma/item/10001-agroecologia-e-org\%C3\%A2nicos-recebem-financiamento-doprograma-ecoforte). Último acesso em 03.12.2017.
} 
produção que envolve a assistência técnica durante todo o período e as exigências da legislação com relação a áreas de policultivos. Historicamente, os camponeses produzem suas sementes crioulas em faixas, no meio de seus demais cultivos, denominado de policultivos.

De acordo com a legislação, a produção de sementes não pode ocorrer em áreas de policultivo. Exige-se áreas separadas para evitar contaminação e monocultivo de sementes. Essa prática nesse formato exclui vários camponeses que não possuem área suficiente de terra para destinar um hectare (1ha) exclusivo para a produção de sementes. A média do tamanho das propriedades dos camponeses multiplicadores está na faixa entre 4 e 5 hectares que corresponde ao tamanho da área que predomina nas propriedades dos camponeses da região (CAPELLESSO, 2016). Assim, a rede de camponeses na dupla ação - guardiã e multiplicadora - e a usina formam um marco nesse território e na atuação do MPA que influencia não apenas a consolidação de algumas das políticas públicas mais importantes do último período para os camponeses, o PAA, como também outros movimentos a iniciarem processo semelhantes na busca de territorialização da soberania genética.

Essa territorialização produziu vários efeitos na forma de organização dos mercados locais de sementes. Os dirigentes do MPA relatam que as agropecuárias nos municípios da região abasteciam seus estoques de sementes, conforme as expectativas da produção e distribuição de sementes realizadas pela Oestebio via PAA. O próprio programa do governo do estado, o conhecido troca-troca, cujas sementes são abastecidas com híbridos e transgênicos das grandes empresas, também diminuiu suas atividades. A produção de sementes tornou-se um dos itens na composição da renda dos camponeses, seja por meio da comercialização da produção de sementes via Oestebio, seja por meio do recebimento dessas sementes como subsídio por aqueles camponeses menos capitalizados.

Mesmo aqueles camponeses que estavam na rede como multiplicadores também percebiam a semente genética para plantio como subsídio, como também o transporte da produção de sementes de sua propriedade até a usina, para o beneficiamento. Esses subsídios foram possíveis de operar em virtude do fomento percebido pela cooperativa que era repassada para os camponeses para estruturação de seus campos de produção.

O MPA acessou a maior parte das políticas públicas disponíveis para estruturar a sua estratégia desde as políticas públicas de assistência técnica e extensão rural às de fomento, com a finalidade de estruturar a usina de beneficiamento e armazenamento, localizada no município de São Miguel do Oeste, no estado de Santa Catarina. Numa estratégia bem estruturada, as políticas públicas foram articuladas e acessadas em diferentes etapas do processo, desde a articulação da rede de multiplicadores que abrangia os três estados de 
abrangência da Cooperativa, a Oestebio - Paraná, Santa Catarina e Rio Grande do Sul - ao financiamento das áreas de produção dos camponeses multiplicadores. Cada política implicou uma forma diferenciada de relações institucionais seja com os camponeses, o MPA e a Oestebio.

O MPA com essa experiência representou interesses para além de seus próprios interesses e dos camponeses que representa. Isto porque a construção da resistência para a constituição de oligopólios no setor de sementes e a conservação de recursos naturais por meio do acervo de sementes crioulas e sua multiplicação é um sinal de que é possível ainda continuar com práticas de manejo da biodiversidade localmente.

\subsection{OS PROCESSOS DE RECONHECIMENTO}

Entendo que é importante situar historicamente as instituições de pesquisa e de ensino que se envolveram no processo para entender como e por que elas se inserem - não apenas porque em certa medida, validaram, reconheceram e colaboraram efetivamente no desenho e redesenho da estratégia operada pelo MPA, como também são estruturantes para pensar numa estratégia de curto, médio e longo prazo, envolvendo a soberania genética e alimentar no país. No próximo bloco, narrarei a partir dos diálogos com pesquisadores, gestores e professores, realizados no trabalho de campo, como se instituiu o envolvimento desses atores e suas instituições no processo.

\subsubsection{A Pesquisa Agropecuária}

Para compreender como se deu a articulação do movimento com o setor de ensino e pesquisa, empreenderei um breve histórico da estruturação desse setor no país, especificamente, da pesquisa agropecuária e de como o mesmo percebe e é envolvido no debate da soberania alimentar e genética na sua relação com o MPA e o projeto nacional de sementes, na medida em que esse setor durante a maior parte de sua existência esteve fortemente comprometido com as políticas de apoio ao agronegócio e, digamos assim, timidamente envolvido ou na maior parte do tempo, de costas para a agricultura camponesa.

Diferentemente, das inovações das políticas públicas criadas nos últimos anos (20032014), enraizada e desenhada fortemente pelas demandas dos camponeses - organizadas pelos movimentos sociais e por parcela da sociedade civil organizada - o campo do conhecimento científico e tecnológico, historicamente, fincou suas origens na oligarquia agrária, mais 
especificamente, a pesquisa agropecuária nacional, bem como, o ensino das ciências agrárias (RODRIGUES, 1987a, 1987b).

A narrativa histórica da estruturação da pesquisa agropecuária no país data três séculos depois da chegada dos colonizadores portugueses ao Brasil, no ano de 1808, com a criação do Jardim Botânico do Rio de Janeiro, por D. João VI. Só após o desmembramento do país da Coroa portuguesa, viria a ser criado os imperiais institutos de agricultura, em 1859, decretados por D. Pedro II, que aliava ensino e pesquisa a luz da experiência das estações experimentais desenvolvidas em solo europeu (RODRIGUES, 1987a).

Rodrigues (1987a) salienta que essa institucionalização, desde o princípio, esteve ligada à economia e as classes sociais dominantes à época, ou seja, à oligarquia agrária e a coroa, que dela se beneficiavam. Não havia interesse da metrópole em desenvolver quaisquer tipos de desenvolvimento científico na Colônia, mas com a oficialização do fim do regime de escravidão, os produtores das commodities da época, cana de açúcar - em crise - e as expectativas em torno da produção do café, houve pressões no sentido de desenvolver tecnologias poupadoras de mão de obra e/ou que colaborassem em aumentar a produção (RODRIGUES, 1987a).

Datam ainda desse período, o Imperial Instituto Bahiano de Agricultura (1859) e os Imperiais Institutos das Províncias do Rio de Janeiro, Pernambuco, Sergipe e Rio Grande do Sul (1860). De acordo com Rodrigues (1987a) apenas os dois primeiros, o Imperial Instituto Bahiano e o da provincial de Pernambuco de fato se consolidaram. As primeiras experimentações com o melhoramento de plantas e distribuição de sementes e mudas para os produtores são realizadas nesses espaços (RODRIGUES, 1987a). O mesmo autor ressalta que em Campinas, foi criada a Imperial Estação Agronômica, em 1859, passando logo em seguida para a administração da província de São Paulo, com a denominação de Estação Agronômica de Campinas. É considerada a instituição de maior longevidade na pesquisa sistemática em torno da agricultura. Vale salientar que nesses espaços se tentava conjugar ensino e pesquisa direcionada para produtores e trabalhadores rurais.

No período da República Velha (1910-1930), foram criadas estações experimentais nos estados de Minas Gerais, Maranhão, Pernambuco, Rio de Janeiro e Rio Grande do Sul. São registros desse período o lançamento das primeiras variedades de cana de açúcar da Estação Experimental de Campos-Rio de Janeiro, denominada com os distintivos CB e, na década de 1930, os trabalhos na área de melhoramento do Dr. Frederico Menezes Veiga (RODRIGUES, 1987b). Os Serviços Especializados tais como Sementeiras, Algodão, Silvicultura e Viticultura para atender os produtores, também datam dessa época. Além desses 
serviços, institutos temáticos tais como o Instituto de Química que depois passa a ser Instituto de Química Agrícola e o Instituto Biológico de Defesa Agrícola surgem também nesse período.

Na chamda Segunda República (1930-1936), ocorreram modificações significativas do ponto de vista da centralização e reorganização do setor, representada pela criação de quatro diretorias na pasta do ministério: Agricultura, Pesquisas Científicas, Indústria Vegetal e Indústria Animal, ambas subordinadas ao Ministério da Agricultura (RODRIGUES, 1987b).

Com a instauração do Estado Novo (1937-1945) há a criação do Centro Nacional de Ensino e Pesquisa Agronômicas/CNEPA e o primeiro Serviço Nacional de Pesquisas Agronômicas/SNPA, contando com três unidades centrais, uma rede nacional de experimentações agrícola, institutos regionais e estações experimentais.

Os institutos de Química, de Óleos e Fermentação que datam do início do século juntam-se aos institutos regionais, a saber: o IAN - Instituto Agronômico do Norte, que englobam os estados do Acre, Amazonas, Maranhão, Pará e Rondônia; o IANE - Instituto Agronômico do Nordeste, abrangendo os estados de Alagoas, Ceará, Paraíba, Pernambuco e Rio Grande do Norte; o IAL - Instituto Agronômico do Leste que inclui os estados de Sergipe e Bahia; o IAO - Instituto Agronômico do Oeste, incluindo os estados de Góias, Minas Gerais e Mato Grosso; o IAS - Instituto Agronômico do Sul, com os estados do Paraná, Santa Catarina e Rio Grande do Sul e ainda o IBA - Instituto de Biologia Animal e o IZ - Instituto de Zootecnia (RODRIGUES, 1987b; FARIA, 1997; BIZZO et. al, 2009).

Essas estruturas iriam sofrer novas transformações na década de 1960 com a reforma administrativa do Ministério da Agricultura, em 1962, onde é extinta a SNPA e criado o Departamento de Pesquisa e Experimentação Agropecuária/DPEA, reunindo as atividades de pesquisas da agricultura, veterinária e zootecnicas numa mesma institucionalidade, buscando a centralização e a execução nas diversas regiões. Os institutos passam a incluir a letra P de pesquisa em suas denominações, assim, IPEAN, IPEANE, IPEAS e assim sucessivamente.

O Sistema Nacional de Pesquisa Agropecuária como o conhecemos hoje nasce no período da ditadura militar no contexto do fortalecimento do desenvolvimento da indústria nacional e com o objetivo de fortalecer o abastecimento do mercado interno e, principalmente, os produtos de exportação com foco na utilização intensiva de capital por meio do pacote da revolução verde que envolvia toda a indústria de novos insumos como máquinas, adubos químicos e agrotóxicos (PEREIRA e CASTRO, 2017). 
Aqui nascia a Embrapa ${ }^{94}$ - Empresa Brasileira de Pesquisa Agropecuária - que incorporou várias das estruturas criadas até então e, ao mesmo tempo, estimulou a criação de empresas nos diversos estados. A Embrapa incubia a elaboração e coordenação da política de pesquisa na área agropecuária nacionalmente. Junto com a empresa, ligada ao Ministério da Agricultura, foi recriado o SNPA - Sistema Nacional de Pesquisa Agropecuário que abrangia às demais empresas no âmbito dos estados. De lá pra cá, muitas alterações ocorreram até o formato atual, em virtude das diversas crises que afetaram o financiamento dessas estruturas, dependentes do orçamento do tesouro nacional, bem como dos contextos de financiamento nacional e internacional; das demandas dos diversos interesses presentes na sociedade, como também, das políticas que sustentam os governos desde então. Já contam quase 45 anos desde sua estruturação (PEREIRA e CASTRO, 2017).

Hodiernamente, os documentos Visão 2014-2034 e o VI Plano Diretor da Embrapa 2014-2034 dão base para a atuação da empresa e foram elaborados a partir de um sistema de inteligência estratégica, denominado Agropensa, e de leituras de cenários para a agricultura brasileira no mundo. Essas orientações estruturam e fundamentam sua estratégia e são operacionalizadas - no nível tático - por meio de portfólios ${ }^{95}$, $\operatorname{arranjos}^{96}$ e macroprogramas ${ }^{97}$ que organizam os projetos nas áreas de pesquisa e desenvolvimento, transferência de tecnologia e desenvolvimento institucional. Atualmente a Embrapa possui na sua programação de pesquisa 25 portfólios temáticos, 6 macroprogramas e 90 arranjos de projetos (EMBRAPA, 2014, 2015a, 2015b, 2017a).

A Embrapa contava até 2017, com 17 unidades centrais, localizadas em Brasília, 46 unidades descentralizadas distribuídas em quase todo o território nacional, três laboratórios virtuais de pesquisa (Labex) - nos Estados Unidos da América do Norte, Europa, China e Coréia do Sul e três escritórios internacionais na América Latina e África. A Embrapa também coordena a rede que compõe o SNPA, abrangendo 16 Organizações de Pesquisa

\footnotetext{
${ }^{94}$ A Embrapa foi efetivamente criada no ano de 1973, por meio da Lei ${ }^{\circ} 5.851$, de 7 de dezembro de 1972.

${ }^{95}$ Segundo Embrapa (2015b), portfólio é um instrumento de apoio para a gestão dos projetos de pesquisa e desenvolvimento, de transferência de tecnologia e de comunicação e desenvolvimento institucional que tem como objetivo "...direcionar, promover e acompanhar a obtenção dos resultados a serem alcançados..." em um determinado tema, dialogando com os objetivos estratégicos da Embrapa (EMBRAPA, 2015b). A definição dos temas dos portfólios originam-se da diretoria executiva da Empresa.

${ }^{96}$ De acordo com Embrapa (2015a), o arranjo de projetos é a figura de gestão organizacional sobre um determinado tema, envolvendo pelo menos mais de uma Unidade Descentralizada e diversos projetos "convergentes, complementares e sinérgicos" (EMBRAPA, 2015a).

${ }^{97}$ Macroprograma (MP) também pertence ao conjunto de ferramentas de administração/organização da programação de pesquisa da Embrapa, estando dividido em 6 temas, a saber: MP1 - Grandes Desafios Nacionais; MP2 - Competitividade e Sustentabilidade; MP3 - Desenvolvimento Tecnológico Incremental; MP4 - Transferência de Tecnologia e Comunicação Empresarial; MP5 - Desenvolvimento Institucional e MP6 Apoio ao Desenvolvimento da Agricultura Familiar e à Sustentabilidade do Meio Rural (EMBRAPA, 2003, 2017a).
} 
Agropecuária-OEPAS, universidades e institutos de pesquisa de âmbito federal e estaduais, empresas privadas e fundações (EMBRAPA, 2017a).

A empresa desde o ano de 2017 vem sofrendo alterações no seu desenho estrutural e no seu regime estatutário ${ }^{98}$ em decorrência da criação de um novo arcabouço jurídico tendo como base a Lei das Estatais - Lei no 13.303 de 30.06.2016; a Lei do Teto de Gastos Públicos - Emenda Constitucional n ${ }^{\circ} 95$ de 15.12.2016 - e a Lei ${ }^{\circ} 13.243$ de 11.01.16 que instituiu o novo marco para a ciência, tecnologia e inovação no país (EMBRAPA 2017b, 2017c, 2017d).

Em que pese essa reorganização esteja em curso, o que já se tem documentado e em vigor está acontecendo especialmente na sede da empresa e em unidades de serviços e que se expressam em extinções, incorporações e reformulações da atuação de unidades centrais e de serviços. Assim, foram extintas até o presente, 15 unidades centrais e quatro unidades de serviços, as quais tiveram parte de suas funções incorporadas por uma nova estrutura organizadas em cinco secretarias, a saber: Secretaria de Inteligência e Relações Estratégicas (SIRE), Secretaria de Desenvolvimento Institucional (SDI), Secretaria Geral (SGE), Secretaria de Pesquisa e Desenvolvimento (SPD) e Secretaria de Inovação e Negócios (SIN) (EMBRAPA, 2017b, 2017c, 2017d).

As empresas estaduais, conhecidas como OEPAS, que estruturam o SNPA ${ }^{99}$, nos últimos anos, vêm sendo profundamente sucateadas, com extinção de algumas instituições históricas como o caso da Fepagro - Fundação Estadual de Pesquisa Agropecuária do Rio Grande do Sul e da Empresa Baiana de Desenvolvimento Agrícola - EBDA. Vale salientar que a rede de escolas de agronomia e universidades, bem como o CNPq, CAPES e demais fundações de fomento à pesquisa no âmbito federal e nos estados, seguiram caminho similar a institucionalização dessa rede de instituições de pesquisa numa ligação estreita tanto no fornecimento de profissionais quanto no desenvolvimento de pesquisa, influenciando-se, mutuamente. Durante a maior parte de sua trajetória a política científica direcionada para a agropecuária brasileira apoiou o desenvolvimento do agronegócio (RODRIGUES, 1987a, 1987b; PEREIRA e CASTRO, 2017).

No que tange especificamente ao campo do melhoramento de plantas, desde o princípio, foi uma linha adotada com prioridade, acompanhando o desenvolvimento desse campo no âmbito internacional. A Embrapa, em particular, desde sua criação mantém cooperações e financiamentos internacionais, participa de fóruns em que há a formulação de

\footnotetext{
98 O novo estatuto da Embrapa foi publicado no Diário Oficial da União, no dia 31.05.2017.

${ }^{99}$ O SNPA sofreu várias reformas e a última foi em 1992, de acordo com a Portaria $\mathrm{n}^{\circ} 193$ do Ministério da Agricultura (MOREIRA e TEIXEIRA, 2014).
} 
estratégias e planos de ação em nível mundial, como por exemplo, nos grupos de trabalho e na Comissão de Recursos Genéticos para a Alimentação e Agricultura/CGRAA ${ }^{100}$ da FAO, instância fundamental na formulação e execução do tema, no âmbito do sistema intergovernamental no mundo.

Há atualmente na carteira de projetos da Embrapa 78 programas de melhoramento que inclui melhoramento genético vegetal, animal e de microorganismos voltados não apenas para a agricultura e alimentação, mas para outros setores como de produção de fibras e energia. A Embrapa possui um dos maiores bancos de germoplasma do mundo e o maior do país e da América Latina, contando com aproximadamente 130 mil amostras de 960 espécies diversas de interesse para a agricultura e alimentação. Além do banco de germoplasma animal, do banco de DNA e Tecidos (EMBRAPA, 2017a). Essa tem se mostrado, ao longo do tempo, uma ação estratégica e faz parte do patrimônio nacional diretamente relacionado à soberania alimentar.

A EPAGRI resulta da fusão das empresas de pesquisa agropecuária - EMPASC - e de extensão rural do Estado de Santa Catarina - ACARESC - Associação de Crédito, Assistência Técnica e Extensão Rural de Santa Catarina, no ano de 1991, quando houve a extinção da Empresa Brasileira de Extensão Rural/EMBRATER e sua rede de Ematers nos estados. Em 2017, a Epagri completou 60 anos, mas a parte da empresa que iniciou com os serviços de extensão rural tem uma atuação mais longígua, datando do ano de 1948.

A Universidade Federal de Santa Catarina - UFSC ${ }^{101}$ completou 50 anos em 2010, criada com a denominação de Universidade de Santa Catarina (USC). O Centro de Ciências Agrárias data de 1969 e é regulamentado pelo Decreto nº 64.629, no auge da ditadura militar, no contexto da reforma universitária e da 'modernização' da agricultura brasileira, intitulado à época de Centro Agropecuário e entrando em funcionamento com a criação do curso de Agronomia no ano de 1975. Vale salientar que esse centro desde sua criação teve forte vínculo com a instituição de extensão rural do Estado, a ACARESC e sua estruturação foi viabilizada por meio de um convênio do governo estadual, operado por essa associação. Assim, grande parte da estrutura física, bem como o quadro de pessoal provinha dessa articulação entre a ACARESC e a Universidade (CAPISTRANO, 2010).

Segundo Geraldi (2007), os primeiros cursos de pós-graduação em Genética e Melhoramento de Plantas no país datam da década de 1960, mais especificamente, do ano de

${ }^{100}$ O CGRFA (Consultive Group on International Agricultural Research) foi criado no ano de 1983, após duas décadas de debate no interior da FAO sobre a conservação dos recursos genéticos no Painel de Especialistas (PISTORIUS, 1997; FAO, 1997).

${ }^{101}$ A criação da UFSC foi sancionada pela Lei no 3.849 e já nasceu universidade federal. 
1964, na Escola Superior de Agricultura Luiz de Queiroz, da Universidade de São Paulo ESALQ/USP. O curso de pós-graduação em Genética e Melhoramento Vegetais da Universidade de Santa Catarina ${ }^{102}$ foi criado no ano de 1998 e até 2007, havia oito cursos de pós-graduação nessa área registrados e reconhecidos pela CAPES (Coordenação de Aperfeiçoamento de Pessoal de Nível Superior).

O autor avalia que esse é um número reduzido comparado ao número de cursos ofertados nessa área nos Estados Unidos, por exemplo, em número de 40, considerando a importância do setor para o desenvolvimento da agricultura no país, bem como sua extensão territorial. Além disso, não havia cursos de pós-graduação em genética e melhoramento nas regiões norte e no centro-oeste do Brasil com características similares, por ocasião desta avaliação. Portanto, além de altamente especializado na linha de pesquisa com melhoramento vegetal, há uma concentração nas regiões sudeste e sul do país, com apenas um curso no nordeste e com baixa integração com os cursos de genética da área de Biológicas 1 conforme classificação das áreas disciplinares avaliadas pela CAPES - que possuía 25 programas de pós-graduação em genética e biologia molecular (GERALDI, 2007).

\subsubsection{EPAGRI}

Os profissionais da EPAGRI, pesquisadores e extensionistas, como pôde ser observado estiveram envolvidos desde o princípio na atividade que envolveu a recuperação das sementes crioulas com os camponeses no Estado, em particular, com aqueles representados pelo MPA. Em um primeiro momento, numa ação realizada pelos extensionistas que estão mais diretamente em contato com os camponeses nos diversos municípios onde esta empresa trabalha e mais tarde, em colaboração com outras instituições como a UFSC e o próprio MPA. Então, o processo histórico do trabalho com as sementes crioulas envolve necessariamente a história de alguns dos extensionistas que passaram pelo escritório local da Epagri no município de Anchieta ${ }^{103}$ e presente nos "testemunhos" dos próprios guardiões e dirigentes do MPA na região.

A presença da Epagri em quase todos os municípios tem um efeito relevante no trabalho local e cotidiano com os camponeses da região como pode ser observado no mapa da

\footnotetext{
102 Único na área de Agrárias 1 com área de concentração em Recursos Genéticos Vegetais, uma área considerada importante nos estudos sobre conservação da biodiversidade do país.

${ }^{103}$ Por ocasião da realização da pesquisa de campo, no município de Anchieta, o prefeito em exercício, Ivan Canci, foi um dos extensionista mais citados entre aqueles com atuação no processo de construção da estratégia de recuperação das sementes crioulas nesse município.
} 
distribuição dos escritórios ao redor do território catarinense. Esses profissionais animam o debate nos temas mais relevantes para os camponeses e, ao mesmo tempo, alimentam o processo de pesquisa. Essa junção das duas atividades na mesma empresa parece produzir um impacto relevante no conjunto da ação estratégica da empresa no Estado.

Figura 6: Mapa com a distribuição das unidades da Epagri.

Fonte: Sítio da Epagri. http://www.epagri.sc.gov.br/?page_id=21005.

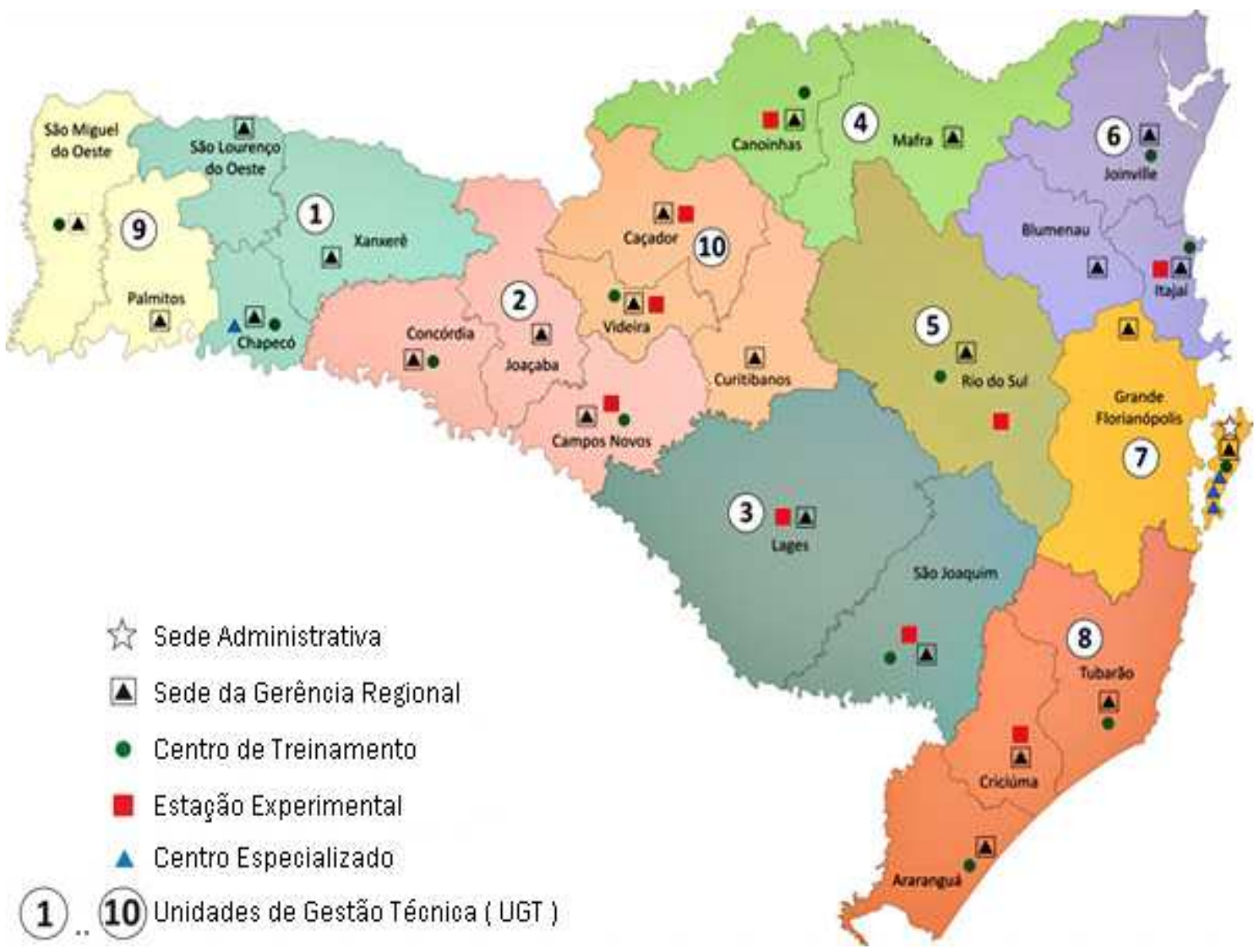

No que se refere ao trabalho de colaboração com o MPA, especificamente no projeto nacional de sementes, a unidade de Pesquisa denominada de Centro de Pesquisa para Agricultura Familiar ${ }^{104} / \mathrm{CEPAF}$, criada no ano de 2002, localizada na cidade de Chapecó, foi

\footnotetext{
${ }^{104}$ Esta unidade foi fundada pelo Ministério da Agricultura em 1948 como Posto Agropecuário de Chapecó, transformada ao longo dos últimos 69 anos, com as seguintes denominações - 1968 - Estação Experimental; 1983 - Centro de Pesquisas para Pequenas Propriedades (CPPP). Disponível em: http://www.epagri.sc.gov.br/?page_id=20354. Último acesso em 03.01.2018.
} 
a unidade que participou por meio de seus pesquisadores ativamente no debate tanto conceitual com relação ao desenho da estratégia dos sistemas de produção de sementes, quanto da instalação da usina de beneficiamento. Além disso, as variedades de polinização aberta (VPA) da Epagri foram incorporadas ao portfólio de variedades produzidas e comercializadas pelo Oestebio em sistema semelhante de cobrança de royalties realizada pelas demais instituições de pesquisa pública, a saber, Embrapa, IAPAR, IAC e FEPAGRO.

Seu programa de melhoramento segue as mesmas diretrizes do SNPA, sendo que a empresa foi uma das pioneiras na pesquisa com variedades de polinização aberta (VPA). A Empresa tem um trabalho importante no desenvolvimento dessas variedades na região Oeste de Santa Catarina, e teve influência na incorporação das mesmas no portfólio da Oestebio. Foi a partir do diálogo com os pesquisadores da Epagri e sua larga experiência com essa atividade que fez com que os dirigentes e camponeses acolhessem a ideia, discutissem e tomassem a decisão de multiplicá-las.

Na compreensão dos pesquisadores entrevistados, o trabalho com as VPAs inicia mais fortemente, após a aprovação da Lei de Cultivares, em 1997, quando as sementes transgênicas passam a ocupar rapidamente o mercado, adquirindo as empresas sementeiras presentes no Estado $^{105}$. E como vimos a LPC impactou na diminuição da oferta de variedades para a agricultura no país na medida em que o marco legal determina a necessidade do uso de sementes certificadas para o plantio e comercialização.

Nesse contexto, os camponeses passam a buscar alternativas para evitar a total dependência de sementes transgênicas, em especial, na produção de culturas para a alimentação humana, como por exemplo, no plantio do milho para a confecção de farinhas e outras formas destinadas ao consumo humano. Isso porque parcela significativa das áreas de produção de milho com sementes transgênicas destinam-se a produção de ração para alimentação animal. Havia uma compreensão semelhante por parte dos pesquisadores e passaram a investir na recuperação tanto de germoplasma crioulos presentes nos bancos de germoplasma, inclusive, da Embrapa, coletado nessa região no passado, quanto no melhoramento das próprias variedades melhoradas. Desse processo, surgem várias VPAs para diminuir esse movimento homogeneizador.

[...] a gente tem essa visão pra não ficar na dependência de germoplasma externo [...] a gente sabia que tem muitos materiais tradicionais que são cultivados há dezenas de anos e a gente fez esses resgates, trabalhou com esses materiais, até para ser fonte de melhoramento ... a visão da pesquisa

\footnotetext{
${ }^{105}$ Uma das empresas sementeiras em Santa Catarina, a Xanxeré do Oeste (Agroeste Sementes), que possuia $10 \%$ do mercado nacional de sementes, foi incorporada pela Monsanto, no ano de 2007 (Disponível em: http://wh3.com.br/noticia/18506/monsanto-fecha-compra-da-agroeste.html). Último acesso em 12.12.2017.
} 
ver mais as sementes crioulas como um banco de germoplasma [...] e as variedades de polinização aberta [...] algumas delas têm essa fonte de milho crioulo, intercruzado com outros materiais adaptados, por exemplo milho crioulo geralmente tem um porte mais alto [...] acima de 2 metros e isso acaba sendo uma característica negativa por causa de regiões que ventam muito, tem quebramento. Então é uma característica que não é propícia e a gente faz alguns intercruzamentos, às vezes com alguns híbridos convencionais de baixo porte e algumas variedades de polinização aberta [...] melhoristas tem essa possibilidade de intercruzar, então eu utilizava toda essa fonte de material para originar a VPA, a cultivar (Entrevista, 2016).

No último período, em função do contexto de restrições orçamentárias, a empresa vem diminuindo a produção de sementes básicas. Os programas de melhoramento genético continuam e nesse contexto há a produção de sementes genéticas. Assim, é necessária a realização de parcerias com outras instituições, como no caso específico dos últimos anos, que ocorreu com a federação dos agricultores na agricultura - FETAESC e sua cooperativa, a Cooarpa $^{106}$, para disponibilizar as sementes básicas e ser possível a multiplicação em maior escala.

No ano de 2016, a Secretaria de Estado da Agricultura e da Pesca (SAR) de Santa Catariana, lançou um programa por meio do Cederural (Conselho Estadual de Desenvolvimento Rural), incluindo uma classificação ${ }^{107}$ para a aquisição de sementes de milho subsidiada pelo estado, no contexto do programa Troca-Troca estadual em Santa Catarina denominado de Terra Boa, onde estão incluídas as sementes varidades e as sementes orgânicas (SAR, 2016).

A falta de alternativas de sementes convencionais, sejam crioulas ou VPAs, vem atingindo o setor de orgânicos no estado. Vejamos por exemplo, o caso particular da cadeia dos produtos de origem animal, como laticínios, suínos e aves destinados à produção orgânica certificada. Não há estudos que dimensionem ainda os efeitos desse processo, mas há relatos de produtores envolvidos nesse mercado de orgânicos que buscam a colaboração da pesquisa no intuito de diminuir suas perdas. A certificação da produção orgânica envolve o

\footnotetext{
${ }^{106}$ A Cooperativa Agropecuária Regional de Pequenos Produtores-Cooarpa, está localizada no município de Mafra/SC. Disponível em: http://www.contag.org.br/indexdet.php?modulo=portal\&acao=interna $2 \& \operatorname{codpag}=101 \& \mathrm{id}=7580 \& \mathrm{mt}=1 \& \mathrm{pt}=1$ ). Última consulta: 02.01.2018.

${ }^{107}$ As sementes a serem adquiridas recebem a seguinte classificação conforme critérios tecnológicos, de produtividade e custeio com os seus respectivos valores monetários: "Grupo I (composta de variedades e orgânicas) - R \$ 40,00; Grupo II - (composta de cultivares de média tecnologia) R \$ 50,00; Grupo III (composta de cultivares de média para alta tecnologia) - R \$ 70,00; Grupo IV (composta de cultivares de alta tecnologia sem tratamento) - R \$ 90,00 e; Grupo V - R \$ 110,00 (composta de cultivares de alta tecnologia com tratamento na Indústria)" (SAR, 2016). Não há uma descrição do que seja média e alta tecnologia sem ou com tratamento na indústria. O camponês recebe um subsídio no valor de $\mathrm{R} \$ 25,00$, tendo como referência a safra de 1 saco de 60kg de milho de consumo tipo II - safra 2017/2018, para a aquisição da saca de 20kg de sementes de milho.
} 
rastreamento da presença de transgênicos. A produção de carne orgânica exige ração orgânica e não há no mercado disponibilidade de ração de milho produzidas com sementes convencional ou crioulas. Desta forma, tornou-se um desafio permanecer no mercado de orgânicos ${ }^{108}$.

O que nos leva a crer que o Estado brasileiro, nos seus diferentes âmbitos - federal, estadual e municipal - avalizou a introdução dos transgênicos no seu território e não desenvolveu quaisquer estratégias no curto, médio e longo prazo para a convivência com essa tecnologia, embora ela tenha impactado diversos setores da cadeia alimentar no país, além de modos de existir dos camponeses. Em especial, nos estados, como Santa Catarina por exemplo, no qual a presença da agricultura camponesa é relevante e estruturante não apenas do ponto de vista da economia, mas sobretudo, da sociobiodiversidade aí inserida.

A força com que o sistema das grandes empresas do setor agroalimentar operou nessas realidades é tão avassaladora que mesmo em contextos com forte presença organizativa como é o caso do Oeste catarinense, onde têm duas federações - FETAESC e FETRAF - que envolve sindicatos de trabalhadores rurais e agricultores familiares, movimentos sociais como MPA e MST, os resultados são preocupantes.

Por outro lado, a entrada dos transgênicos das grandes empresas, reduzindo a adoção das variedades da pesquisa pública, também diminuiu a ação extensionista na medida em que as sementes representam uma das possibilidades do acompanhamento das lavouras onde aquela variedade está sendo cultivada. O que impacta nos custos de produção dos camponeses porque esse tipo de serviço já vem imbutido no pacote tecnológico que ele acessa.

No último período, tem diminuído a participação dos camponeses e técnicos de cooperativas nos projetos de pesquisa de melhoramento, especialmente, em comparação com o período anterior quando havia a rede nacional de melhoramento e aconteciam as reuniões técnicas por cultura, como por exemplo, cultura do milho e do feijão.

No caso do MPA, em particular, a EPAGRI foi demandada pelo movimento e eles então elaboraram um projeto para trabalharem em conjunto, com recursos do MDA. Desse

\footnotetext{
${ }_{108}$ Por outro lado, vejamos por exemplo, o que vem ocorrendo com o agronegócio da soja que também já percebeu por força das "leis do mercado" que consumidores internacionais também exigem o direito de escolher o alimento que consomem. Nesse sentido fundaram, em 24 de julho de 2017, um instituto denominado Instituto Soja Livre, uma iniciativa da Aprosoja Mato Grosso e Embrapa, com o objetivo de desenvolver o mercado de soja convencional (Ver: https://www.embrapa.br/en/soja/convencional/sojalivre). Nesse processo, estima-se que a safra do grão convencional em 2017/2018, no estado do Mato Grosso, atingirá 15\% da área plantada, o que na última safra representou 13,7\% ou 1,2 milhão de hectares (Ver: http://sna.agr.br/plantio-de-soja-convencionaldeve-atingir-15-da-area-em-mato-grosso/). Vale salientar que esta iniciativa não só conta com apoio do grupo Amaggi da família do atual ministro da agricultura, Blairo Maggio, que ofertam prêmios para os agricultores que introduzem em suas terras a soja convencional (Ver: https://br.reuters.com/article/businessNews/idBRKBN1872RM-OBRBS). Última consulta em 04.01.2018.
} 
projeto varias ações foram realizadas no contexto dos sistemas de produção de sementes, com produção de cartilhas direcionadas ao tema, capacitações e orientação no processo de instalação da usina de beneficiamento, incluindo, o parecer técnico para o funcionamento. Além disso, o movimento solicitou a utilização dos laboratórios de sementes da empresa. Então, foi uma colaboração importante no momento de estruturação do projeto.

Há uma compreensão muito clara que os camponeses em Santa Catarina, nesta região Oeste, com pequenas áreas para o cultivo de milho - entre 1 ou 2 ha - destinado em grande parte para a confecção de silagem para alimentar os animais, não tem como arcarem com o alto custo de produção da aquisição de um saco de sementes transgênicas ${ }^{109}$, que exige um sistema intensivo de insumos e que podem ser rapidamente perdidos com os constantes eventos climáticos que vem ocorrendo no Estado.

O governo estadual, como já mencionado anteriormente, por meio do Conselho Estadual de Desenvolvimento Rural - Cederural, elaborou o programa específico direcionado a agricultura familiar do estado, denominado de Terra Boa - que se baseia na metodologia do programa de equivalência em produtos, popularizado de troca-troca, especificamente direcionado a cultura do milho e que visa distribuir 220.000 (duzentas e vinte mil) sacas de sementes de milho para os camponeses que acessam o PRONAF e suas organizações (SAR, 2016). O que se percebe é que os programas são em grande parte emergenciais e não levam em consideração a questão da soberania genética ou a autonomia dos camponeses.

Esses programas são realizados em colaboração com as cooperativas produtoras de sementes que tem capital para investir tanto na logística do beneficiamento quanto na de distribuição e que envolve, nos dias atuais, as grandes empresas multinacionais do setor que ao adquirirem as empresas regionais, assimilaram a cadeia de cooperativas e agropecuárias que antes operavam com as empresas locais.

Vale salientar que essa ideologia do uso das sementes híbridas e dos transgênicos envolve um forte marketing que as empresas públicas de pesquisa não conseguiram desenvolver e que diz respeito a um plano de divulgação das variedades por meio de outdoors, nos diversos períodos da lavoura - antes do plantio, durante o desenvolvimento da planta e depois da colheita. Além de um serviço de transferência de tecnologia espelhado nas práticas históricas de extensão rural que envolve 'lavouras demonstrativas' e dias de campo, acompanhados de festividades. Então, há uma forma de construção da imagem do produto

\footnotetext{
${ }^{109}$ Valor da saca contendo 60.000 unidades de sementes de milho híbrido simples, OGM BT, tratada - no mês de setembro de 2017, constava de $\mathrm{R} \$ 562,00$ no site da CONAB. (Disponível em: http://consultaweb.conab.gov.br/consultas/consultaInsumo.do?method=acaoListarConsulta). Última consulta em 04.01.2018.
} 
como em qualquer outro mercado consumidor que certamente está incorporado no custo da semente, mas que não se vê. É um desafio, porque incorpora uma estética que impressiona muitos camponeses e vai roubando sua autonomia no longo prazo.

Reintroduzir as VPAs e as crioulas nesse universo necessita de uma estratégia para além da doação dessas sementes pelos mercados institucionais. Uma das alternativas envolve os programas de governo como o troca-troca, que inclusive já vem sendo reivindicado pelo movimento social e pela rede Ecovida de Agroecologia, em Santa Catarina, de inserí-las no programa estadual. No entanto, quem comercializa essas sementes são as cooperativas dos camponeses e as empresas agropecuárias nos municípios que muitas vezes têm relações com as grandes empresas e o compromisso de comercialização com as mesmas. Então, é uma rede que envolve muitos atores e diversas relações de interesse e que não dizem respeito diretamente as características de qualidades da semente.

\subsubsection{UFSC}

A forma como os pesquisadores e professores enxergam o mundo é por meio de conceitos. No caso da pesquisa aplicada cujas atividades se relacionam com questões práticas, aplicadas aos problemas cotidianos, esses conceitos tornam-se mais específicos/estreitos. Assim que no tema das sementes crioulas isso ficou bem perceptível e a cada pesquisador ou camponês que conversei essa questão vinha à tona. Assim, na Universidade Federal de Santa Catarina, no curso de pós-graduação em recursos genéticos vegetais, o tema está inserido em um debate maior sobre biodiversidade e dentro desse, o da agrobiodiversidade.

[...] que envolve parte da biodiversidade que se torna utilizável [...] ela engloba não só as variedades de plantas, os animais, mas também os outros componentes que sustentam a produção, por exemplo, os polinizadores, as micorrizas, tudo que é biota. Então esses componentes também fazem parte da agrobiodiversidade. $\mathrm{E}$ as variedades crioulas, elas estão nesse contexto, então ela faz parte da concepção que nós temos aqui não só da parte que é domesticada como as variedades crioulas, como também as espécies que não são domesticadas ou são manejadas só pela humanidade (fala do entrevistado, 2016).

A fala acima faz parte do diálogo sobre como a universidade se inseriu no debate sobre as sementes crioulas e o projeto de sementes do MPA. Nesse sentido, foi explicitado que a UFSC por meio de alguns professores tem contribuído, ao longo do processo, tanto no debate teórico e conceitual sobre a soberania genética na perspectiva da agrobiodiversidade quanto em atividades práticas e de formação relacionadas à operacionalização do projeto, estando aí inseridas: o melhoramento participativo, a capacitação e o monitoramento da 
contaminação por transgênicos nas sementes provenientes dos campos de produção dos camponeses multiplicadores, a orientação acadêmica, entre outras.

No trabalho específico do monitoramento da contaminação por transgênicos, a universidade também avalia os lotes que os técnicos da Oestebio identificam contaminação para validação e o resultado é que a cada ano esse número é crescente. O que é preocupante visto que esse crescimento da contaminação rebate nos custos de produção da cooperativa que tem que descartar lotes de sementes e, na mesma medida também recai sobre os custos de produção dos camponeses multiplicadores que são obrigados a comercializar sua produção, antes sementes, como grãos, o que diminui a sua valoração. Essa realidade confirma as afirmações de Gilles et al. (2009):

Pode-se afirmar, sem temor, que a disseminação voluntária dos transgenes no meio ambiente vai obrigatoriamente acarretar contaminações genéticas por fluxo de pólen e sementes ou mistura de sementes. Em outras palavras, a maioria dos cultivos convencionais será contaminada, num certo índice, por transgenes de cultivos de plantas transgênicas vizinhos. Esses cultivos convencionais contaminados deverão ser considerados como transgênicos e, portanto, desaparecerão à medida que os cultivos com variedades transgênicas se ampliarem. [...] A coexistência sem contaminação, portanto, é impossível (GILLES, 2009, pg. 15).

Essa situação afeta não apenas os camponeses sob o ponto de vista mais imediato nos custos de produção e comercialização das sementes que produzem, mas no longo prazo a autonomia de um conjunto maior de camponeses que dependem dessas sementes crioulas ou varietais para dar continuidade aos seus sistemas de produção livre de transgênicos. Em cadeia, retira a liberdade de escolha de consumidores que preferem se alimentar de forma orgânica e livre de organismos geneticamente modificados ${ }^{110}$.

A universidade também organizou cursos de formação para os camponeses organizados pelo MPA na região sul, envolvendo camponeses dos estados do Rio Grande do Sul e Santa Catarina, para contribuir no debate sobre o tema na rede do movimento com recursos provenientes de editais do $\mathrm{CNPq}^{111}$, nos últimos anos. Esse é um processo considerado importante porque envolve a institucionalidade tanto da universidade quanto do movimento e realizado em parceria com outras organizações sociais, diminuindo os custos de sua realização, em especial, com hospedagem. Esses cursos envolvem desde questões

\footnotetext{
${ }^{110}$ Há um debate sobre a coexistência entre os modos de produção convencional e os plantios transgênicos - que levam em consideração não aspectos biológicos e físicos da contaminação, mas sobretudo as formas específicas de organização do espaço agrário, os modos de organizar os sistemas de produção camponesa e familiar no país e a cadeia agroalimentar no seu conjunto que envolve a estrutura de beneficiamento, armazenamento e transporte - que deveria ter sido considerada na formulação da normatização que regulamenta tal situação no país. Para uma análise crítica sobre o tema, ver por exemplo Gilles et al. (2009).

${ }^{111}$ Conselho Nacional de Desenvolvimento Científico e Tecnológico - CNPq.
} 
conceituais às questões técnicas que tratam da implementação de campos de produção de sementes.

Vale salientar que quando a universidade foi convidada a participar, os camponeses já estavam organizados e realizavam o trabalho de recuperação e manutenção de suas variedades, como mencionado anteriormente. Portanto, já havia um processo em curso, tanto do ponto de vista de compreensão do processo de conservação quanto da organização. Nesse espaço, a indústria ainda não conseguiu imprimir sua concepção de que o camponês que assegura sua semente para o próximo plantio é atrasado ou não tecnificado. Ainda assim, há uma preocupação com a perda desses saberes que envolvem a guarda e a reprodução das sementes que vêm sendo corroído por essa ideologia da modernidade agrícola. Com a adoção das sementes híbridas e transgênicas a transmissão desses saberes de geração para geração vêm se perdendo, o quê tem se tornado uma das principais preocupações dentro do contexto de algumas disciplinas nesse programa. Uma frente considerada importante é a recuperação dessa capacidade dos camponeses de fazerem seus processos de seleção de sementes.

Nesse sentido, há um debate com o movimento sobre uma ação mais coordenada e direcionada para a especialização no interior da rede dos camponeses envolvidos no processo para o desenvolvimento de capacidades/habilidades para a atividade de melhoramento. Muitos dos camponeses guardiões que realizavam tal ação foram no decorrer do processo dedicando-se à atividade de multiplicar. Essas duas atividades exigem dedicação e tempo para serem feitas com a qualidade exigida.

Por isso há que se consolidar um eixo mais estratégico nessa direção, assim como foi construído com a rede dos multiplicadores de sementes, premida pelas pressões do aumento no volume de produção, no contexto do PAA. Pensar a rede de guardiões melhoristas possibilitará imaginar a sustentabilidade do processo ao longo do tempo. Porque sai da lógica do parâmetro único da produtividade e valoriza muitos desses guardiões que já vem por gerações desenvolvendo ações de melhoramento.

[...] alguns deles tem a habilidade de olhar para a planta e dizer, aquela vai dá bem ... então ....não dá para apostar tudo num caminho só e aí no próprio movimento eles têm esse debate. Eles inclusive estão desenvolvendo híbridos [...] Ninguém sabe o que vai acontecer daqui a 10 anos com essas mudanças climáticas [...] aumentar 2 graus essas variedades pode tirar elas não irão produzir muito. Então tu tens que ter um grupo de pessoas que vão fazer a seleção permanentemente porque aí você mantem a diversidade... (Entrevista, 2016).

Esse é um debate que permeia a fala da maioria dos diálogos que foram desenvolvidos no decorrer da pesquisa de campo, não apenas pelos pesquisadores, mas sobretudo, pelos 
camponeses e dirigentes do movimento que entendem que a soberania genética depende fortemente desse eixo que envolve o desenvolvimento de novas variedades, um trabalho realizado por gerações pelos guardiões, mas que necessitam de reconhecimento e valoração pelas políticas públicas.

Se de um lado, as variedades de sementes - sejam dos camponeses e/ou da pesquisa pública - estiverem em permanente esforço de adaptação, ao longo do tempo, terão maiores chances de adaptarem-se às mudanças. Por outro lado, se há uma atividade que remunera o trabalho do camponês como é a produção de sementes, certamente, o voluntariado representado pela ação dos guardiões, pode está ameaçada. Então, pensar a valoração dessa atividade como eixo estruturante no interior da estratégia tem sido repensado conjuntamente pelas instituições de apoio e pelo próprio MPA.

No interior do curso de pós-graduação em recursos genéticos vegetais da UFSC ainda que o tema da agrobiodiversidade tenha alcançado um patamar importante, ele ainda não tem status de linha de pesquisa, mas é um objeto de pesquisa relevante e com um conjunto de estudos realizados. Certamente, a ação da UFSC nesse espaço tem colaborado sobremaneira na construção do processo de soberania genética com os camponeses da região do Extremo Oeste do estado, especialmente, no município de Anchieta. Esse município é caracterizado como um microcentro de diversidade genética do milho, demonstrado por Costa (2013), no contexto dos trabalhos de tese e dissertações desenvolvidos no interior do programa com o tema da agrobiodiversidade.

Em conjunto com outras instituições, a UFSC, por meio dos trabalhos desenvolvidos pela professora Juliana Bernardi Ogliari, está reivindicando a proteção daquela área como livre de transgênicos por entender que por ser um centro de diversidade e as áreas com transgênicos caminharem cada vez mais próximas das áreas desses camponeses agrobiodiversos, a probabilidade de contaminação é premente. Assim, eles vêm realizando várias ações políticas no sentido de dar visibilidade e preservar o trabalho desenvolvido pelos camponeses durante gerações e que se mantém nos dias atuais na região. Nesse sentido, foi realizado, em julho 2017, no município de Anchieta, o Seminário ${ }^{112}$ para discutir a Indicação Geográfica das variedades dos milhos crioulos da região. No conjunto, os trabalhos desenvolvidos nesse contexto qualificam a UFSC como referência na realização de pesquisas contextualizadas em um campo do conhecimento cujo imaginário nos remete a laboratório e

112 Matéria divulgada no portal da prefeitura do município de Anchieta, no sítio http://www.anchieta.sc.gov.br/noticias/index/ver/codNoticia/435641/codMapaItem/8589. Último acesso em 23.12.2017. 
câmaras frias e, muito menos ainda a resultados com impactos diretos na vida dos camponeses e suas autonomias.

Essas novas concepções e abordagens de realizar pesquisa na pós-graduação, especificamente, nessa área, não é tão comum o quanto seria necessário e os recursos destinados a elas também são escassos. Então, professores que fazem opção pelo tema e por abordagens participativas necessitam diversificar a agenda no intuito de ampliar as fontes de financiamento.

\subsubsection{EMBRAPA}

A semente como pode ser observado toma diversos significados dependendo do contexto onde ela se insere. No decorrer das últimas décadas, ela tornou-se um dos centros dos conflitos socioambientais, envolvendo, tanto o acesso do ponto de vista de insumo agrícola quanto como insumo científico, ou seja, como fonte de germoplasma no campo do melhoramento genético.

Vimos que após tornar-se mercadoria com a colaboração da pesquisa científica, a semente tonou-se objeto de disputa, não apenas no campo do mercado de commodities, mas também no campo da ciência, com relação aos métodos mais adequados para a conservação desse material genético em benefício não apenas da ciência - para a continuidade do trabalho do melhoramento, seja melhoramento tradicional ou na transgenia - mas sobretudo, para a sustentabilidade alimentar das gerações futuras. Vamos tratar aqui de como o tema alcança as instituições que colaboraram no desenho, estruturação e operacionalização do projeto de sementes do MPA.

É interessante notar que os pesquisadores envolvidos no processo do MPA desenvolvem um trabalho com o tema do melhoramento de plantas e, mais recentemente, com o melhoramento participativo ${ }^{113}$, em particular. São pesquisadores com mais experiência na pesquisa e que já acompanharam algumas transições no foco e no trabalho sobre sementes crioulas. O tema da erosão genética data do início do século XX e o debate de como os países deveriam se organizar para enfrentá-lo ocorre logo após o fim da Segunda Guerra Mundial, no contexto das conferências da FAO, em fins da década de 1960 (PISTORIUS, 1997; FAO, 1997; KLOPPENBURG, 2004).

O Brasil irá participar dessas atividades e será envolvido ainda nos anos 1950-1960 nos projetos financiados pela fundação Rockefeller com a colaboração de cientistas

\footnotetext{
${ }^{113} \mathrm{O}$ conceito de melhoramento participativo pode ser encontrado em Machado (2014).
} 
americanos para a ampla coleta de sementes ao redor do mundo. Enquanto toda a estrutura de pesquisa no mundo e no Brasil voltam-se para a estruturação dos bancos de germoplasma, apostando na conservação ex situ ${ }^{114}$ e coletando sementes dos camponeses para abrigar nas câmeras frias, já havia cientistas, à época, que acreditavam que era necessário investir também na conservação in situ.

Ainda que, mesmo aqueles que entendiam que deveria haver investimento na conservação in situ, o conceito subjacente era de que a semente representava um insumo importante para a melhoria dos processos de melhoramento das plantas e o ambiente era um fator determinante nesse processo do ponto de vista ambiental na medida em que confere maior variabilidade genética.

Assim, as primeiras coletas realizadas por pesquisadores na década de 1970 e 1980, ainda consistia em enxergar as sementes crioulas - que ainda não recebiam este conceito - que estavam em mãos dos camponeses, denominadas como tradicionais, como um recurso genético, um germoplasma para serem incorporados aos projetos de melhoramento e aos bancos de germoplasmas para conservação. Nesse processo, alguns pesquisadores passam a ter um contato mais direto com os camponeses e a conhecerem as formas como eles manejam seus cultivos e guardam suas sementes.

Essa relação de colaboração caracteriza-se mais por parte dos camponeses que cede a sua semente (sua fonte genética) que propriamente uma troca ou um intercâmbio. Pode-se identificar esse como um primeiro movimento de aproximação, que continua nos dias atuais, mas que em alguns casos, como no exemplo na Embrapa Clima Temperado, as relações se aprofundam e há um envolvimento na co-construção das estratégias de conservação, utilização e compartilhamento não apenas das sementes, mas de saberes, dos camponeses e da própria pesquisa agropecuária.

O trabalho diretamente com os camponeses na perpectiva de um melhoramento participativo inicia muito timidamente por pressão do movimento social que busca a Embrapa para constituir cooperação. Uma das primeiras organizações que busca a colaboração da Embrapa, por exemplo, é a AS-PTA/Fase com o objetivo de instituir a Rede de Sementes. No caso, da Epagri, como vimos anteriormente, são os próprios camponeses que possuem uma relação mais estreita com os extensionistas dos municípios e conseguem dialogar localmente e expressar suas demandas. Essa aproximação, ainda que diferentemente, parte

\footnotetext{
${ }^{114}$ A conservação ex situ diz respeito à conservação de recursos genéticos fora de seu habitat natural e a conservação in situ corresponde a conservação de recursos genéticos no seu habitat natural, incluindo a conservação on farm (VEIGA et al., 2012; SANTONIERI e BUSTAMANTE, 2016).
} 
majoritariamente dos camponeses e das organizações que os apoiam, seja ONGs técnicas ou empresas de extensão rural, ou suas representações sociais.

De todo modo, como já citado anteriormente, há um movimento internacional que produz não apenas orientações políticas e técnicas, mas sobretudo, disponibiliza recursos no contexto dessa estratégia que vialibiza a incorporação de projetos de melhoramento de plantas nas instituições de pesquisa para a coleta das sementes junto aos camponeses. Muitos dos projetos das décadas de 1970-1980115 fazem parte desse contexto.

De acordo com FAO (1997) e Pistorius (1997), a preocupação com o problema da erosão genética e a perda progressiva e crescente da diversidade do material genético dos agricultores, ou seja, das sementes crioulas, ao redor do mundo, data da década de 1930, com o avanço das variedades híbridas, especialmente, nos países em desenvolvimento. Mas é apenas na década de 1950 e 1960 que são instituídas ações para tratar da coleta, conservação e troca de germoplasma no contexto dos Estados com foco principalmente nas culturas comerciais.

Assim, em 1963 é instituído o Painel de Especialistas sobre a Exploração dos Recursos Genéticos e em 1974 é criado o CGIAR - Grupo Consultivo sobre Pesquisa Agrícola Internacional para Recursos Genéticos de Plantas. Nas décadas seguintes - 19701980 - são criados os bancos de germoplasma116 a luz da estratégia da conservação ex situ, que recebe enormes somas de recursos para viabilizá-la. Dessa forma, foram criadas as coleções de germoplasmas no âmbito internacional e nacional ao redor do mundo. O Brasil participa amplamente dessa etapa e constitui os bancos da pesquisa agropecuária, como por exemplo, os bancos da Embrapa que se encontram distribuídos por diversas unidades descentralizadas ${ }^{117}$, tendo a Embrapa Cenargen ${ }^{118}$ como unidade central para o tema, além de empresas de pesquisa estaduais, institutos de pesquisa e universidades que possuem programas históricos com melhoramento de plantas (FAO, 1997; MARIANTE et al., 2009).

\footnotetext{
${ }^{115}$ Ver a tese de doutoramento de Santonieri (2015) que elabora uma etnografia sobre o caso específico da Embrapa e a constituição da conservação ex situ.

${ }^{116}$ Os primeiros trabalhos com conservação ex situ e constituição de um banco de germoplasma vegetal datam de antes da Segunda Guerra Mundial com Nicolai Ivanovich Vavilov, na Rússia. No Brasil, a iniciativa de conservação de recursos fitogenéticos se dá com Maurício de Nassau, na cidade do Recife/PE com a criação do Jardim Botânico, destruído logo que os holandeses partem do país. Ainda, em 1798, por orientação de D. Maria foi criado o Jardim Botânico, em Belém, no estado do Pará (VEIGA et al., 2012).

${ }^{117}$ Ver o sítio http://alelobag.cenargen.embrapa.br/, em que constam informações sobre os BAGs. Última consulta 21.02.2018.

${ }^{118}$ A Embrapa possui hoje o maior Banco Genético do país e da América Latina, representando um dos maiores do mundo, contendo aproximadamente 130 mil amostras de 960 espécies variadas de relevância para a agricultura e alimentação (Embrapa, 2017a).
} 
Em fins da década de 1980, pesquisadores iniciam uma nova abordagem com o trabalho de conservação, ou seja, a conservação in situ, onde o espaço do camponês, seu ambiente - sua propriedade/lavoura - passam a desempenhar um papel importante no processo de seleção das variedades a serem melhoradas. Do ponto de vista do melhorista, essa nova abordagem parte do princípio que o ambiente possui um papel preponderante na determinação da qualidade da semente melhorada.

O melhoramento tradicional privilegia as atividades em campos experimentais, um espaço idealizado, com ótimas condições artificiais (uso de adubo e agrotóxicos) e depois produz recomendações universalizadas para o seu uso, o que exige a reprodução dessas condições “ideais”. Esse tipo de melhoramento não exclui o uso de sementes crioulas, tanto o é que muitos pesquisadores nesse período já realizavam coletas dessas sementes dos camponeses em diferentes regiões, incluindo, no sul do país, para a realização de projetos de melhoramento ou, simplesmente, mantê-las nos bancos de germoplasmas dessas instituições. O que é distinto dessa nova abordagem de conservação in situ on farm conforme detalhado em Santonieri e Bustamante (2016).

Nesse novo enfoque, os testes de seleção passam a ser realizados em ambientes reais, ambientes dos camponeses, suas lavouras ou nos espaços por eles designados, e as propriedades genéticas dessas sementes seriam ali expressas, correspondendo a essa interação do potencial genético e aquelas condições ambientais e culturais específicas. Em alguns casos, utilizando inclusive as práticas e manejos dos camponeses na condução de suas lavouras. Nessa visão de conservação ativa entende-se que há maior probabilidade de ampliar a diversificação, pois diferentemente da coleção que é estática e, portanto, produtora de baixa variabilidade. De acordo com Veiga et al. (2012), a escolha da abordagem deve levar em consideração as características das espécies, as condições adversas do manejo, os objetivos do processo de conservação/preservação, dentre outros fatores para a realização dessas atividades.

De todo modo, essa abordagem é considerada por alguns pesquisadores de difícil assimilação pela Embrapa Cenargen, ainda que seja a unidade que tenha a missão de coordenação do tema, na medida em que sua origem está intrinsicamente gestada com a política que gerou e implementou a conservação ex situ no país. Ainda que essa unidade, tenha nos últimos anos, alocado recursos humanos - na contratação de pessoal - e implementado na sua programação de pesquisa via projetos e arranjos o desenvolvimento do tema, está distante de alcançar patamares semelhantes ao trabalho desenvolvido com a conservação ex situ em termos de número e tamanho de equipes envolvidas, volume de 
recursos e disponibilidade de tempo. Então, no ritmo e no tamanho dos esforços empreendidos nesse tema, nesse centro específico, ainda tem um longo caminho a ser percorrido.

As razões que explicam tais dificuldades não se relacionam apenas às questões de valorização do tema, mas pode está relacionada a uma cultura institucional instalada há mais de 40 anos que, certamente, expressa uma opção política anterior e contínua. Por outro lado, este novo fazer exige uma construção de capacidades e habilidades que vão além da formação técnica que os pesquisadores recebem nas instituições de ensino e pequisa e que dizem respeito à construção de relações de confiança e respeito com as comunidades camponesas, indígenas e tradicionais que demandam um maior envolvimento, o que representa tempo e recursos. Nem mais e nem menos que os processos anteriores, mas muitíssimo diferente. Portanto, é um desafio para a empresa deslanchar esse tema.

O certo é que o debate internacional que ocorre no interior da CDB entre os países desenvolvidos do Norte e os em desenvolvimento do Sul sobre como os recursos naturais deveriam ser tratados a partir de então, desencadeiam um redirecionamento da FAO frente a esse novo debate (MCAFEE, 1999) e tem impacto na forma como os métodos de conservação de recursos genéticos devem seguir nas instituições de pesquisa dentro do sistema constituído no século passado, incluindo, aí no Brasil. Não há o abandono da conservação ex-situ, mas há uma orientação para a incorporação da conservação in situ on farm. Há um ambiente favorável ao desenvolvimento do tema, inclusive com recursos. Certamente divergências sobre qual o formato a seguir, dentro dessa abordagem, gera uma nova arena de debates, na medida em que as instituições de financiamentos sempre enviam uma metodologia empacotada de cima para baixo a serem seguidas.

Nesse sentido, McAffe (1999) discute como esse novo momento vem sendo tratado desde a década dos anos de 1990 a partir da elaboração de tratados internacionais como a CDB que surge para dar sustentação aos novos paradigmas do desenvolvimento e da economia verde com suporte financeiro do banco mundial. Assim, nas palavras da autora:

By promoting commoditization as the key both to conservation and to the equitable sharing of the benefits of nature, the global environmentaleconomic paradigm enlists environmentalism in the service of the worldwide expansion of capitalism. It helps to legitimate and speed the extension of market relations into diverse and complex eco-social systems, with material and cultural outcomes that to diminish than to conserve diversity and sustainability (MCAFEE, 1999, pg. 135).

Isso porque, explica a autora, na base da CDB há um pressuposto de medição para a precificação da vida, demonstrando as três formas de poder em ação: o poder do discurso, o 
poder institucional e o poder econômico, reforçando a injustiça ambiental que se consolida ao redor do mundo, representado pelo aprofundamento dos desequilíbrios e das desigualdades históricas entre os países do Norte e do Sul; entre as populações urbanas e rurais; entre os agricultores e camponeses com terra e sem terra, bem como as disputas sobre os limites da soberania.

Para o caso específico da Embrapa, mesmo encontrando essas dificuldades, ou seja, o silêncio quanto a conservação in situ, em algumas unidades descentralizadas da Embrapa, como por exemplo, na Embrapa Clima Temperado, algumas iniciativas foram tomando formas por dentro dos programas de melhoramento convencional, em diversas culturas como feijão, arroz, milho, entre outras, nos anos de 1980. No decorrer desse processo, compreenderam que havia interações para além do ambiente físico. Havia um camponês que não apenas mantinha e guardava suas sementes, mas ainda praticava processos de seleção e conservação de suas sementes por muitas gerações, dando continuidade aos processos que historicamente realizaram. Então, esse manejo e esses recursos dos camponeses passaram a ter nova valoração no contexto da conservação in situ por parte da pesquisa.

Mas, é apenas na década dos anos dos 2000, que o trabalho com os guardiões de sementes passam a fazer parte oficial de alguns projetos com melhoramento participativo, sendo institucionalizado na programação de pesquisa da Embrapa. Vale salientar que já havia anteriormente, trabalhos com melhoramento participativo, onde material da Embrapa e ou sementes dos próprios camponeses compunham os experimentos realizados pelos pesquisadores em modelos comparativos. No entanto, esses projetos aconteciam por dentro dos programas do melhoramento convencional de forma não explícita e não tinham a visibilidade que tomou nos últimos anos.

$\mathrm{Na}$ sequência, as transformações que ocorreram, primeiramente na sociedade brasileira, com a mudança no cenário político, colaboram e produzem efeito direto na forma como a Embrapa vai estruturar sua programação de pesquisa, desde a década dos 1990, aprofundando-se na década dos 2000, com uma abertura maior para o acolhimento das demandas da agricultura familiar e camponesa, inclusive com a criação de um programa de pesquisa, denominado de Macroprograma 6, direcionado a agricultura familiar, nos primeiros anos do governo Lula, em 2004 (PENTEADO et al, 2014; GASTAL, 20--).

Esse macroprograma, intitulado Apoio ao desenvolvimento da agricultura familiar e a sustentabilidade do meio rural, nasceu das demandas da sociedade civil, no primeiro ano do governo Lula, no ano de 2003, bem como de grupos de pesquisa dentro da Empresa que já trabalhavam com o tema. É a abertura deste espaço institucional que possibilitou o 
acolhimento de várias e diferentes abordagens de pesquisa, focado na pesquisa participativa e pesquisa ação, nos quais se inserem os projetos de melhoramento participativo, bem como os projetos com os guardiões de sementes. Assim, esse macroprograma é instituído tendo como objetivo:

[...] a gestão de uma carteira de projetos voltados para fornecer suporte a iniciativas de desenvolvimento sustentável da agricultura familiar e de comunidades tradicionais, na perspectiva de agregação de valor e, prioritariamente, com abordagem territorial, promovendo a convergência de esforços multi-institucionais e interdisciplinares, nos quais os componentes de pesquisa e desenvolvimento (P\&D) e de transferência de tecnologia (TT) relacionados ao mandato da Embrapa sejam relevantes (PENTEADO et al., 2014, pg. 53).

Nesse período, a empresa recebe importantes aportes financeiros do Programa Fome Zero e vários projetos são alocados nesse macroprograma, entre os quais os projetos relacionados ao melhoramento participativo da Embrapa Clima Temperado. É no contexto desse financiamento que nascem as experiências com os guardiões de sementes e se estruturam os eventos que dão visibilidade a esta iniciativa por parte da Empresa, especialmente no Rio Grande do Sul. São encontros, feiras, eventos internacionais, entre outros, envolvendo os camponeses guardiões de vários municípios desse estado.

Há iniciativas em outras unidades que passam a ter visibilidade nesse mesmo período em razão dos temas da segurança alimentar e nutricional e da agrobiodiversidade tornarem-se eixo estruturante de políticas públicas com dotação orçamentária e prioridade governamental. Assim, pode-se citar experiências com melhoramento participativo e com guardiões de sementes na perpectiva acima referida nas unidades da Embrapa Algodão, Embrapa Cerrados, Embrapa Cenargen com foco em populações indígenas e tradicionais, Embrapa Pantanal e Embrapa Tabuleiros Costeiros. Muitas dessas unidades com trabalhos que datam da década de 1980. Nesse contexto, várias e diferentes metodologias são criadas como, por exemplo, a de Partitura da Biodiversidade que reúne o registro das sementes crioulas e as avaliações dos camponeses. Assim descreve o pesquisador que co-construiu essa abordagem:

[...] com a ideia de que cada variedade crioula seria uma nota musical e o conjunto dela seria uma partitura e aí nós começamos a distribuir algumas coleções, principalmente partituras, algumas coleções de variedades crioulas para alguns agricultores organizados experimentarem, tendo a Emater como nosso parceiro na escolha desses agricultores, preferencialmente guardiões. Então isso tem algumas finalidades, uma delas é a manutenção das variedades, contrariamente ao processo de erosão, na medida em que distribui essas variedades, há uma grande possibilidade que algumas delas seja adotada pelos agricultores e [...] na medida que alguns desses agricultores preservam uma variedade destas tu estais evitando o processo de erosão [...] e na medida que as variedades nossas é incorporada no sistema 
de produção do agricultor tu aumentas a diversidade genética sob a questão mais genética $[\ldots]$ tu diminuis a vulnerabilidade da cultura porque quanto mais diversa for uma população, menos vulnerável ela é a qualquer problema ambiental seja ele biótico ou abiótico (Entrevista, 2016).

Há um conceito importante envolvido nesse tipo de trabalho que é o entendimento da conservação ativa ou on farm. Não se constrói conservação apenas com sementes congeladas, consideradas apenas como componente dentro dos bancos de germoplasma, com o uso reduzido nos programas de melhoramento das empresas. Mas sobretudo, com a dinâmica do manejo e do uso pelos camponeses, em que há maior possibilidade para a criação/manutenção da diversidade/variabilidade, e ao mesmo tempo, diminuindo a uniformidade genética tão propalada nas últimas décadas pelo uso das sementes híbridas e transgênicas. Por isso o papel dos guardiões é tão importante no processo de conservação.

O processo de criolização na conservação da agrobiodiversidade tem um papel fundamental, pois ela garante a possibilidade da persistência/continuidade da variabilidade e da diversidade. Esse processo diz respeito às variedades crioulas que estão em poder das empresas de pesquisas e das universidades, em seus bancos de germoplasma, mas também as sementes dos camponeses que estão em uso e sistemas de intercâmbio nesses projetos de melhoramento participativo, que no caso específico da Embrapa Clima Temperado, com as PBIOs (Partituras da Biodiversidade) de feijão que já constam mais de 200 distribuídas. De concepção recente, as sementes crioulas expressam o reconhecimento dessa relação dos camponeses com a natureza.

[...] quer dizer uma variedade adaptada para um ambiente específico e que contém um elemento cultural agregado a ela que está ligado ao fato de como cultivar, como utilizar né tem uma tradição acumulada na semente em si. Isso é variedade crioula. $\mathrm{E}$ além disso tem o reconhecimento [...] da comunidade onde ela está inserida (Entrevista, 2016).

De fato, a semente que o camponês maneja está ligada à sua experiência de vida e seu universo particular - que incorporam valores desde a cultura alimentar às questões do espaço reservado as suas lavouras/roçados, bem como ao ambiente que o circundam. É ele que escolhe manter as características que no seu ponto de vista são relevantes e que dizem respeito às finalidades e propósitos que sustentam as suas formas de vida e que ultrapassam a questão da produtividade ou redução de custos que é central no melhoramento convencional direcionado às variedades comerciais, sejam híbridas ou transgênicas. Assim características nutricionais, de sabores, de tradição, de resistência e rusticidade compõem o rol de critérios que fazem parte dos processos de seleção realizados pelos camponeses. De fato é um olhar que busca as qualidades, mas que as quantidades. 
Esse movimento de melhoramento participativo das sementes crioulas, com o tempo, passou a reconhecer essa rede de guardiões e suas percepções. Nas palavras de um dos entrevistados, é a recuperação da humanização dos processos biológicos e genéticos que envolve a produção das sementes. Um aspecto importante desse trabalho de melhoramento participativo é que ele envolve não apenas o guardião camponês, o homem ou a mulher camponesa, mas envolve a família camponesa, ela é a guardiã das sementes que compõem a cesta da dieta alimentar da família. Então, esse trabalho que iniciou com sementes de feijão miúdo, foi ampliado na medida em que o olhar sobre o conjunto do sistema de produção e reprodução familiar foi sendo incorporado a essa abordagem.

Nesse sentido, hoje o conjunto de espécies trabalhadas envolve feijão, milho, hortaliças, mandioca, amendoim, curcubitáceas, leguminosas de duplo propósito, plantas de cobertura, entre outras. Essa ampliação exige um esforço maior e o envolvimento de uma equipe multi e interdisciplinar, em virtude do formato disciplinar e especializado que a pesquisa tradicional está estruturada, seja nas empresas de pesquisa, como também, nas universidades. Ao buscar colaboração nesses espaços, encontra-se um especialista, que sabe sobre uma parte específica sobre um todo de um problema. Além disso, cada uma dessas espécies recebe um tratamento diferenciado que considera suas especificidades genéticas e agronômicas, além da própria organização no sistema mais geral de estruturação da pesquisa agropecuária. Há redes de avaliação de variedades para diferentes culturas, mas não de sistemas de produção pluricultivos que se aproximem dos desenhos dos roçados ou das lavouras dos camponeses.

A pesquisa com melhoramento participativo é um encontro de no mínimo dois mundos. O do pesquisador especialista que sabe muito sobre uma determinada espécie, em particular, como por exemplo, o feijão ou o milho e, os guardiões, o mundo da complexidade que enxerga o seu sistema de cultivo no seu conjunto em interação com um ambiente singular - socioeconômico, cultural e natural. Uma determinada espécie num conjunto sistêmico, no qual está envolvido diversos fatores que compõe o funcionamento muito particular de organização produtiva e reprodutiva.

O guardião de sementes crioulas não se especializa, mas guarda sementes dentro da estratégia de produção e reprodução familiar, incluindo o sistema produtivo em si e, sobretudo o sistema de reprodução. Mesmo assim, há nesse universo uma diversidade de tipos de guardiões. Os guardiões que conservam/guardam, os guardiões melhoristas/experimentadores, os guardiões especialistas/colecionadores de uma espécie em 
particular, as mulheres guardiãs, todos esses representam um elemento cultural importante no processo de preservação e conservação dos recursos genéticos da agrobiodiversidade.

Há uma preocupação crescente que junto com o processo de erosão genética esse saber, esse conhecimento que envolve essas atividades se percam, na medida em que os camponeses são obrigados a utilizar as sementes transgênicas dos pacotes recomendados, principalmente, aqueles que estão integrados nas indústrias de suínos e aves no estado de Santa Catarina. Ou ainda, aqueles que dependem da utilização de sementes distribuídas nos programas de troca-troca ou outros programas abastecidos com híbridos e transgênicos pelos governos estaduais. Há um contexto bastante propício para que a erosão genética inclua também o desaparecimento de um saber secular de melhoramento e conservação realizado historicamente por essas famílias guardiãs camponesas.

Além de não haver incentivos e valorização desses serviços prestados a coletividade, presente e futura, pelo Estado, há uma pressão crescente das empresas multinacionais e de grupos de interesse contra o que eles denominam sementes piratas, incluindo nesse jargão, as sementes crioulas das famílias camponesas. O que essas empresas objetivam é uma reserva de mercado para instituir o monocultivo exclusivo dos transgênicos, como já vimos anteriormente, no processo de constituição dessa realidade no país e no mundo por meio da construção de um arcabouço normativo que obriga a todos o uso de suas sementes.

O trabalho desenvolvido seja pelas empresas de pesquisa e pela universidade em colaboração com os guardiões é de fundamental importância para a continuidade e preservação desses saberes que estão envolvidos na produção e conservação de sementes da agrobiodiversidade. Tanto os camponeses enviam suas sementes para os pesquisadores que desenvolvem todo um trabalho de caracterização, seleção, melhoramento e conservação quanto compartilha material com os camponeses dos acervos das crioulas e das variedades que compõem o acervo dos bancos de germoplasma da pesquisa agropecuária. Esse é um trabalho de intercâmbio de saberes e co-produção de conhecimentos de enorme validade para o progresso não só da ciência mas para a conservação desse patrimônio e que deve encontrar mecanismos para ser amplamente desenvolvido nos diferentes biomas ao redor do país.

Esse processo que envolve os guardiões tem se tornado significativo e em alguns municípios e regiões estão se constituindo associações de guardiões para a realização de trocas de sementes e conhecimentos, uma forma vitalizada de manter essa tradição viva. Além disso, um dos entrevistados ressalta que mesmo que o movimento tenha trabalhado, nas últimas décadas, para a reapropriação desse conjunto de saberes e dessa riqueza de material que se encontra com os camponeses é importante constituir formas de formação para 
recomposição dessas práticas de melhoramento realizadas pelos camponeses e que em muitas regiões encontram-se perdidas. Nem todos os camponeses são e serão guardiões, mas aqueles que desejam, é importante recuperar, ativar e preservar esse tipo de conhecimento.

O MPA nesse sentido, já vem desenvolvendo compostos que é um tipo de variedade, produto de cruzamentos sucessivos de variedades crioulas e variedades da própria pesquisa, fruto das aprendizagens não apenas da convivência com os pesquisadores e das experimentações realizadas, mas do investimento na formação de técnicos e profissionais da Oestebio, filhos de camponeses, que no último período, estão inseridos no programa de pósgraduação em Recursos Genéticos, na Universidade Federal de Santa Catarina, em nível de mestrado e doutorado ${ }^{119}$.

Essa interação é fruto desse processo de construção do projeto nacional de massificação que envolve a prática cotidiana na condução do processo da produção de sementes na rede dos camponeses multiplicadores e da usina de beneficiamento e armazenamento e a necessidade de apropriação e aprofundamento teórico que os capacitem e lhes deem autonomia. É um reconhecimento relevante da universidade que acolhe uma inovação/experimentação social no contexto da pós-graduação e que tem implicações práticas no decorrer do processo.

Pode-se observar que foi um longo caminho até aqui e há por parte dos pesquisadores um reconhecemento de que este é um momento favorável para a ampliação e fortalecimento dessa abordagem de pesquisa na medida em que o país está comprometido formalmente com vários tratados e acordos internacionais, em particular com a CDB - que envolve o tema da biodiversidade e a repartição de benefícios - que tem desdobramentos na regulamentação interna e implicações práticas no fazer científico e no trabalho dos pesquisadores e, em particular, na relação com os camponeses ${ }^{120}$.

Além disso, no último período, a presença forte dos movimentos sociais nos diferentes espaços institucionais seja no âmbito federal, regional ou estadual, como por exemplo, no processo de elaboração da PLANAPO, reforçando a importância da abertura da empresa aos anseios de parcela da sociedade que historicamente esteve excluída de suas decisões, colaborou, inclusive, nas adequações das normas internas que tratam do tema. Vale salientar que os camponeses não participaram diretamente da elaboração das normas, mas pesquisadores ligados ao tema e que desenvolvem pesquisas com camponeses, comunidades

\footnotetext{
${ }^{119}$ Exemplos de trabalhos acadêmicos realizados no contexto dessa estratégia incluem os dos técnicos da Oestebio, Munarini (2013) e Nerling (2017), ambos no Programa de Pós-graduação da UFSM, em Recursos Genéticos Vegetais.

${ }^{120}$ Ver por exemplo as orientações reunidas em Vasconcelos (2016), no contexto da pesquisa e desenvolvimento.
} 
tradicionais e povos indígenas foram inseridos nos grupos de trabalho para reelaboração dessas orientações normativas que regulamentam o trabalho com recursos genéticos na empresa.

Além disso, várias modificações na institucionalidade da programação de pesquisa expressam essas transformações e acolhimento do tema na empresa, como por exemplo, o novo portfólio e arranjos que dialogam diretamente com a temática, tais como, o Portfólio de Sistemas de Produção de Base Ecológica ${ }^{121}$ - dentre os 25 outros portfólios que abrange a programação como um todo - que terá implicações no longo prazo, pois que a vida na empresa se organiza por meio dessas institucionalidades que se desdobram em formação de redes e colaborações, interna e externa (EMBRAPA, 2017a).

Além desse, há o Portfólio referente aos recursos genéticos, denominado de REGEN122 - Gestão Estratégica de Recursos Genéticos para a Alimentação, a Agricultura e a Bioindústria, no qual abrange três eixos, o vegetal, o animal e o de microorganismos, dentre os quais tem um projeto de conservação in situ on farm. Então, há possibilidades de desenvolvimento de projetos e de diálogos para a ampliação do tema no interior do sistema de pesquisa agropecuária, na medida em que esses portfólios se organizam a partir de redes internas e externas, portanto recebem contribuições de diferentes redes como explicitado anteriormente. Mesmo que o pensamento que predomine nesses espaços seja o de como a conservação in situ on farm possa beneficiar a ex situ, há o espaço de diálogo para a troca e mudança de concepções. Isso já pode ser considerado um avanço e um espaço para a criação de um diálogo e interação das experiências em curso.

Por outro lado, há a parte comercial nessas empresas de pesquisa que tem vida própria e que envolve a negociação da genética que é produzida nos seus programas de melhoramento e muitas vezes, completamente deslocada e sem diálogo com as relações que foram

\footnotetext{
${ }^{121}$ O objetivo deste portfólio no sítio da Embrapa vem descrito como: “[...] ampliar a sustentabilidade ambiental, econômica e social da agricultura familiar, esse portfólio contribuirá para a geração de conhecimentos e tecnologias para os sistemas de produção orgânicos, agroecológicos, ou em transição, de forma a possibilitar a otimização do uso dos recursos disponíveis. Atua em temas como: agrobiodiversidade; manejo de sistemas de produção animal e vegetal; insumos para sistemas ecológicos de produção; qualidade, processamento e póscolheita, entre outros" (https://www.embrapa.br/pesquisa-e-desenvolvimento/portfolios). Último acesso em 31.12.2017.

${ }^{122}$ Assim está descrito no sítio da empresa, o portfólio REGEN: “Tem como objetivo garantir a manutenção de forma organizada, das Coleções de Germoplasma da Embrapa em todas as suas formas e reinos, com a maior variabilidade genética possível. Este portfólio inclui todas as ações necessárias à manutenção, ao enriquecimento e à caracterização dos Núcleos de Conservação Animal, das Coleções Biológicas de Microrganismos, dos Bancos de Germoplasma Vegetal, das suas coleções de germoplasma mantidas a médio e longo prazo (Banco Genético), bem como das coleções de referências e das ações relacionadas à conservação in situ de recursos genéticos. Para isso, este portfólio de projetos é constituído por três Vertentes: Recursos Genéticos Animais, Recursos Genéticos Microbianos e Recursos Genéticos Vegetais. Inclui ainda ações de Documentação (Portal Alelo), Intercâmbio, Quarentena, Sistema de Qualidade e Legislação relacionada ao tema Recursos Genéticos" (https://www.embrapa.br/pesquisa-e-desenvolvimento/portfolios). Último acesso em 31.12.2017.
} 
construídas no decorrer dos processos que acontecem nos programas de melhoramento participativo descritos até aqui. No caso da Embrapa, em particular, vem sendo realizada por meio de uma de suas unidades, uma unidade de serviço, denominada de Embrapa Produtos e Mercados com a qual o MPA mantém convênio para poder acessar as variedades da empresa. Da mesma forma, ocorre com as demais empresas de pesquisa (Epagri, IAPAR, IAC, etc) com as quais o movimento por meio da Oestebio reproduz suas variedades. Assim, há normas e contratos próprios que regulamentam o pagamento dos royalties já mencionados anteriormente.

Vale salientar que esse setor, historicamente, negocia a comercialização da genética da empresa com diversas cooperativas no país - das grandes às pequenas cooperativas - e, inclusive sementes da Embrapa Milho e Sorgo, antes desse processo com a Oestebio, foram plantadas em áreas de multiplicação de sementes de alguns camponeses nessa região, na década dos 1990, com outras cooperativas quando a realidade dos transgênicos e a disputa comercial com os países do Mercosul ainda não existiam.

Cooperativas de pequeno porte que não tinham a mesma estrutura que a Oestebio possui hoje e, com um menor número de camponeses envolvidos, essa era uma realidade comum antes da década dos 1990. Os camponeses familiares organizados em cooperativas conseguiam fazer a disputa com as sementeiras tradicionais e produziam suas próprias sementes numa escala maior. É desse processo também que vem a experiência de alguns dos camponeses que hoje integram a experiência do MPA, cujos filhos atuam na direção do MPA, da Oestebio e das redes de guardiões e de multiplicadores.

$\mathrm{Na}$ compreensão dos atores envolvidos nesse movimento, esse tema já está institucionalizado dentro da Embrapa e é considerado irreversível, pois que expressa uma demanda não apenas dos movimentos sociais e ambientais, mas sobretudo, uma compreensão do próprio campo científico com as aprendizagens do passado e do presente, no âmbito internacional e nacional. Assim, no Congresso Brasileiro de Recursos Genéticos ${ }^{123}$, organizado pela Sociedade Brasileira de Recursos Genéticos (SBRG), que ocorreu em Curitiba no ano de 2016, aconteceu a I Feira Nacional de Guardiões da Agrobiodiversidade, algo comum nos eventos da agroecologia e que pela primeira vez ganhou espaço nesse evento patrocinado pelas multinacionais do setor.

\footnotetext{
123 Consta da programação na página do evento. Disponível em: http://cbrg2016.com.br/index.php/programacao/feira-nacional-de-guardioes-da-agrobiodiversidade. Último acesso em 11.11.2016.
} 
Certamente, o trabalho individual do pesquisador que acolhe o tema, a abertura nas unidades descentralizadas, e sobretudo, o contexto internacional e nacional ${ }^{124}$ fez com que o tema das sementes crioulas e seus guardiões fossem incorporados na programação e agenda de pesquisa, com perspectivas de curto, médio e longo prazo, como pode ser observado pela reorganização interna das empresas de pesquisa por meio da programação de pesquisa, nas suas normativas internas ou ainda no acolhimento do tema e de pessoas ligadas ao movimento social nos programas de pós-graduação da UFSC. Esse tempo deixa marcas importantes na história da ciência e do próprio movimento social brasileiro.

Ainda na compreensão de alguns dos pesquisadores entrevistados, assim como foi no movimento da conservação ex situ, o SNPA brasileiro pode se tornar referência para o conjunto do sistema de pesquisa agropecuária na América Latina nesse tema, tanto porque há uma institucionalidade em construção e, sobretudo porque há no país, um camponês consciente e organizado, em um contexto internacional favorável para que isso ocorra.

Por fim, foi esse grupo de pesquisadores que participaram no processo da construção da experiência do MPA e que colaborou no redesenho da estratégia com relação ao uso das variedades de polinização aberta disponível nas empresas de pesquisa pública (e que reforça a compreensão dos pesquisadores da Epagri). Como ressaltado anteriormente, o projeto inicial do MPA dizia respeito à massificação das sementes crioulas, exclusivamente, daquelas em poder dos camponeses. No processo de discussão com o grupo de pesquisadores da Embrapa, Epagri e da Universidade Federal de Santa Catarina outras iniciativas foram discutidas e algumas incorporadas na composição do que se tornou o projeto de massificação como analisado aqui nesse trabalho.

Pode-se observar que há uma convergência na centralidade dos objetivos das instituições envolvidas e do próprio movimento que conduzem a um processo de conservação. Os camponeses buscam a autonomia socioeconômica que substancie o projeto político de soberania alimentar. Os pesquisadores buscam reduzir a erosão genética e preservar a variabilidade dos recursos genéticos e evitar a monocultura da vida que leva inevitavelmente ao estreitamento da diversidade. E é essa aliança de compromissos que o MPA conseguiu consolidar, acolhendo esses interesses e introduzindo as variedades da pesquisa pública no seu portfólio de sementes.

\footnotetext{
${ }^{124} \mathrm{O}$ trabalho com os guardiões de sementes da Embrapa Clima Temperado entrou recentemente para o rol da Plataforma de Boas Práticas para o Desenvolvimento Sustentável da FAO, no contexto do Programa de Cooperação Internacional Brasil-FAO (http://www.boaspraticas.org.br/index.php/pt/areastematicas/alimentacao/620-guadioes1). Último acesso 12.01.2018.
} 
As evidências levam a compreender que essa habilidade de escuta e a flexibilidade de incorporar diferentes abordagens, sem perder o foco no objetivo maior, fez com que o movimento fosse no decorrer do caminho ajustando sua estratégia e conquistando espaço nas diferentes instituições na qual buscou colaboração. O movimento passou a colaborar nos projetos acima referidos e tem participado ativamente nos espaços abertos nas empresas de pesquisa, seja em eventos, seja no envolvimento da rede de guardiões no processo de experimentação com as PBios.

Vale salientar que os contatos iniciais, seja com a Epagri, a Embrapa e mesmo com a UFSC, aconteceram, inicialmente, com pesquisadores individuais e só depois, institucionalmente. Os indivíduos parecem ser a porta de entrada das instituições. O que pode ser uma característica da ausência de uma ação mais ativa de comunicação ou interação das instituições, não apenas com o seu entorno, mais sobretudo, com as dinâmicas presentes na sociedade. Não há um observatório ou um processo de prospecção do que está ocorrendo na sociedade. O movimento parece acontecer quase sempre da sociedade organizada para dentro das instituições e não o inverso, das instituições para a sociedade. $\mathrm{O}$ que pode dificultar o acesso a essas instituições aqueles camponeses sem a forte presença de um movimento social organizado.

\subsection{APRENDIZAGENS DA CONSTRUÇÃO DA SOBERANIA}

Um dos primeiros problemas encontrados foi a ausência de protótipos de máquinas e equipamentos destinados a agricultura camponesa familiar. Nesse sentido, para beneficiar e armazenar sementes a única referência de uma usina de beneficiamento e armazenamento foram os armazéns nos moldes tradicionais de processar a produção de sementes, no formato convencional em que grandes volumes de sementes são armazenadas em grandes galpões para posterior distribuição. Daqui surge o desafio para o manejo da usina e seu formato convencional de armazenar. No início, os técnicos tentaram não fazer uso de agrotóxicos, usaram armadilhas no espaço do galpão para conter os roedores e uma mistura (terra de diatomáceas) para encobrir/proteger as sementes para evitar o ataque dos carunchos. Mas a quantidade de sementes estocadas em grande volume, totalmente comprometida para abastecer o mercado institucional e, a voracidade do ataque dos visitantes não desejados, sem conseguirem controlar com os meios descritos acima, exigiu uma tomada de decisão que evitasse a perda total do estoque e os prováveis prejuízos econômicos advindos dessa situação e, uma reconfiguração do projeto inicial na tentativa de tornar-se agroecológica foi operada. 
Nesse sentido, foram obrigados a fazer uso de agrotóxicos quando necessário, ainda que em uma dosagem menor que a inicialmente recomendada pelo técnico que comercializou os produtos para o uso. Atualmente, eles aplicam 50\% da dosagem recomendada pela empresa. Na verdade, esse tipo de estocagem não deixa de ser um monocultivo, com volume considerável de alimentos disponíveis para insetos, animais e outros hospedeiros. As sementes foram trazidas em perfeita ordem das propriedades dos camponeses como explicar e justificar a perda dentro dos armazéns da cooperativa. É uma situação complexa porque envolve recursos financeiros do Estado, dos camponeses, da Oestebio e do próprio movimento, que além disso, envolve o capital político completamente comprometido com a inovação do projeto de massificação.

$\mathrm{O}$ aumento de escala possibilitou perceber as contradições dos modos de gerir o projeto tanto do ponto de vista do modelo de agricultura que o engendra - a escala, o volume - quanto dos conflitos históricos de acesso a recursos quando envolve terra e capital. O armazenamento em larga escala é um problema, o risco de contaminação é grande; não há tratamento agroecológico eficaz para guardar as sementes em grande volume. Ou seria possível dizer que a grande escala não condiz, ou melhor, contradiz os princípios defendido por esse paradigma? Nessa experiência mostrou-se desafiante a convivência com os dois paradigmas.

Alguns problemas na massificação das crioulas foram relatados porque a produção das sementes crioulas, inicialmente, perfazia $70 \%$ em termos de diversidade (qualidade) das sementes produzidas. No processo, houve modificações para que a experiência fosse tomando o formato atual. De todo modo, o caso específico das crioulas diz muito a respeito de sua própria característica como já discutido anteriormente. Como as sementes foram distribuídas em vários e diferentes municípios e estados, as reclamações se avolumaram em decorrência dessas características locais que a semente assume, ou seja, suas características morfológicas e a descrição que os camponeses de uma determinada localidade lhes conferem.

O nome de uma semente varietal vem do nome da empresa que a registra, muitas vezes, seguida de um número ou um nome. No caso das crioulas não. A identidade é uma criação de um camponês guardião que a compartilha na sua comunidade ou entre seus familiares, assim é uma identidade de um coletivo, seja comunitário ou familiar, e carrega o nome de batismo que o camponês que a selecionou lhe deu e sua circulação muitas vezes está restrita a uma comunidade. Assim, pode haver várias sementes crioulas com o mesmo nome e quando é plantada, os agricultores de um lugar pode não a reconhecer como sendo aquela determinada crioula que ele conhece. Então, esse trânsito das sementes crioulas de um lugar 
para o outro produziu diversos estranhamentos e não reconhecimentos em função dessa característica do desenvolvimento dessas sementes.

Em Santa Catarina, por exemplo, onde muitas organizações sociais adquiriram sementes da Oestebio/MPA, por meio da CONAB, para seus associados (sindicatos, associações, cooperativas, entre outros) foi fácil identificar essas reclamações porque chegaram até a cooperativa. Então, há uma complexidade maior na hora de massificar uma variedade que é "local", de um "lugar" muito específico e distribuí-la numa escala maior. O camponês de uma determinada região planta esperando encontrar aquela semente que ele imagina que seja a que ele conhece, mas pode ser surpreendido e não ser a semente outrora de sua comunidade. Esse processo gera um certo descontentamento e uma desconfiança de que estejam agindo de má fé. Na verdade, as crioulas são identidades locais de uma vizinhança.

Além disso, as sementes crioulas exigem um sistema de cultivo diferente das variedades convencionais ou híbridas, especialmente, de um maior espaçamento entre as linhas na hora do cultivo, são menos plantas por hectare, o que pode afetar o seu desempenho. E nem todos os camponeses que receberam as sementes estavam acostumados com esse tipo de sementes. Há camponeses que plantam há décadas os híbridos e variedades convencionais, portanto, desconhecem os sistemas exigidos para o plantio com as crioulas e simplesmente não consideraram este comportamento. Com o decorrer da experiência, as sementes crioulas que apresentavam problemas como os relatados acima, foram sendo substituídas por aquelas que apresentavam amplitude de adaptação maior para serem reproduzidas. Nesse processo, as sementes crioulas foram bastante reduzidas, no caso do milho, em particular, foram reduzidas a dois crioulos, o MPA01 e o Pijurun $05^{125}$.

As demais sementes crioulas continuam sendo produzidas, mas em pequena escala, em que eles sabem que há uma demanda e os camponeses conhecem. Cada cultura tem um percurso próprio. O caso do feijão é muito particular porque está completamente inserido na dieta alimentar do camponês, então ele tem uma relação especial com uma determinada semente crioula de feijão. O entendimento é de que certas sementes crioulas são difíceis de serem massificadas porque está incorporada apenas no "gosto" de algumas comunidades camponesas, bem como o porte que alcançam não permite a mecanização. $O$ feijão é um cultivo que compõe o ciclo do sistema de cultivo do camponês dessa região (fumo-milhofeijão) que tem sabores diversos como os feijões vermelho, verde, azul e azulão, todos de

\footnotetext{
${ }^{125}$ Essas sementes são consideradas crioulas de acordo com o conceito da legislação atual, mas elas são compostos, produtos de melhoramento de pesquisa participativa realizado por pesquisadores e camponeses, no estado de Santa Catarina (informação obtida por meio de entrevista realizada durante a pesquisa).
} 
porte não ereto, que exige colheita manual. Nesse sentido, massificar apresenta alguns limites para determinados cultivos, como aqui exemplificamos, no caso do feijão.

Ainda assim, quando há solicitação para uma determinada semente crioula, mesmo de feijão, a cooperativa articula a rede para a produção. Assim, ajustes foram necessários no decorrer do percurso, conforme os problemas e os desafios surgiram. A experiência tem mostrado que a estratégia de massificação tem que respeitar a complexidade envolvida nos processos produtivos e nos diferentes âmbitos da organização social camponesa. As sementes crioulas carregam consigo um modo de organizar o tempo, o espaço, os sabores e a cultura do lugar, seja de uma família, de uma linha ${ }^{126}$ ou comunidade.

Nesse processo de massificação, as sementes crioulas saem da propriedade do guardião para a usina de beneficiamento, onde procedem a limpeza, classificação, testes de germinação e seguem para os campos de produção dos multiplicadores. Ao retornarem para o processo de beneficiamento na usina, são beneficiadas, classificadas, armazenadas, comercializadas e logo distribuídas para onde haja demanda identificada pela CONAB. Assim, as crioulas seguem um caminho inteiramente novo dos padrões de usos anteriores, nos quais já havia um reconhecimento prévio seja pelo uso ou pelo compartilhamento de experiências de outros camponeses com seu uso.

Por outro lado, na compreensão dos pesquisadores envolvidos no processo de diálogo com os dirigentes e camponeses do MPA, com uma capacidade instalada de aproximadamente quatro mil toneladas, a usina da Oestebio poderia não conseguir o efeito esperado apenas utilizando sementes crioulas. Assim, a inclusão das sementes varietais, provenientes do melhoramento participativo com camponeses de diferentes ecossistemas, poderia ampliar essa capacidade e fazer frente ao avanço dos transgênicos e híbridos. Afinal, esses recursos estavam nas unidades de pesquisa sem uso e poderia ampliar o leque de opções dos camponeses no momento da escolha de sementes para plantio. E assim, como vimos as variedades da pesquisa pública passa a compor a estratégia da Oestebio.

No que tange a essas sementes, elas também apresentaram problemas, diferentemente dos relatados até aqui com relação às crioulas, as reclamações centraram-se sobre a qualidade de sua germinação. Essas reclamações serviram para o aprimoramento do trabalho, na medida em que ao visitarem os camponeses, conseguiram identificar as causas geradoras dos problemas. Em uma dessas visitas, relataram a confusão causada na aparência das sementes,

\footnotetext{
${ }^{126}$ Linha é o nome local para a estrada vicinal e dependendo da localização da comunidade, se em paisagens acidentadas, inclui pouquíssimas famílias em propriedades com poucos hectares de terra (observação da pesquisa de campo).
} 
as quais eram tratadas com a terra de diatomáceas no armazenamento. Essa substância similar a um pó branco foi confundida com sementes atacadas por carunchos, que produz efeito visual semelhante ao produto aplicado às sementes, o que gerou reclamações.

A condução de lavouras com o milho crioulo necessita de uma área maior por conta que essas sementes exigem espaçamentos maiores que as varietais. Alguns agricultores em virtude de não possuírem mão de obra disponível preferem as varietais porque podem utilizar máquinas para fazer o manejo (limpeza). Os camponeses tem clareza dos problemas gerados pelo uso dos agrotóxicos, há relatos de camponeses que estão em tratamento de câncer ocasionados pelo uso desses venenos em suas lavouras. Ao mesmo tempo, eles encontram dificuldades para realizar e conduzir suas lavouras, na medida em que estão integrados em plantios convencionais. E mesmo aqueles que tentaram fazer a transição para o sistema agroecológico, eles afirmam que esses são mais exigentes em mão de obra, atualmente escassa na região e que não há maquinário adequado para esses sistemas disponíveis no mercado.

O problema da falta de mão de obra para condução agroecológica, sem a necessidade do uso de agrotóxicos (herbicidas), por exemplo, na limpeza das áreas nos períodos exigidos pela normatização da produção de sementes crioulas foi um dos problemas enfrentados, pois que ainda necessita que seja realizada manualmente.

A uma enorme lacuna entre a necessidade real de continuar produzindo; produzir sem envenenar o próprio organismo e o ambiente e as condições tecnológicas objetivas que ainda não atentou para o fato de que há lugares em que a mão de obra humana está escassa, portanto, há que se desenvolver instrumentos considerando esta realidade. Além de que, a penosidade do trabalho na agricultura, seja do ponto de vista do esforço físico desenvolvido no trabalho manual, com a enxada ou quaisquer outros instrumentos manuais e a exposição excessiva a radiação solar, com casos comprovados de câncer de pele nessa região, são razões suficientes para o desenvolvimento de pesquisas que busquem preencher essas lacunas seja por meio de máquinas ou o desenvolvimento da robótica.

Por que não há máquinas e equipamentos desenvolvidos para os sistemas agroecológicos, considerando variáveis como escassez de mão de obra, penosidade do trabalho e impacto ambiental? Por que não há volume suficiente de pessoas para adquirir e tornar-se lucrativo? É preciso pensar em alternativas que permitam que camponeses que desejem permanecer no campo produzindo, agroecologicamente, possam lá produzir com segurança e alegria. 
Por fim, o exercício de participação política nos espaços de poder que foram sendo instituídos no decorrer do governo Lula foram fundamentais e estruturantes no decorrer do processo da experiência do movimento. Nesses espaços, eles puderam expressar os problemas reais vivenciados pelos camponeses e ao mesmo tempo, colaborar na reformulação da política pública, conforme a experiência se estruturava. Essa colaboração recíproca foi importante porque permitiu que o fluxo de informações entre os gestores governamentais e a base do movimento, nem sempre em concordância, estivessem sempre atualizada. As evidências relatadas demonstram que os avanços que favoreceram a massificação, em parte decorrem desses espaços de diálogo, onde as dificuldades e os desafios do processo puderam ser ouvidos e incorporados. A participação do representante do MPA no CONSEA ${ }^{127}$, no qual tem representação de membros do MDA, MDS, representantes da sociedade civil, dentre outras instituições.

\section{SÍNTESE DO CAPÍTULO}

Este capítulo discutiu o processo de construção da experiência de massificação que foi colocada em campo pelo movimento por meio de sua cooperativa Oestebio, no município de São Miguel do Oeste, envolvendo uma rede de camponeses entre guardiões e multiplicadores, no território do estado de Santa Catarina, como também, nos estados do Paraná e no Rio Grande do Sul.

Descreveu-se a construção da articulação das instituições técnicas e científicas para operacionalizar os sistemas de produção de sementes, bem como, a usina de beneficiamento de sementes e colocar em funcionamento o processo de comercialização por meio do PAA. Além dessa política, um conjunto de outras foram acionadas para apoiar o processo desde o seu nascedouro até sua inteira implementação, envolvendo um conjunto de técnicos, dirigentes, gestores e assessores na operacionalização da estratégia.

Foi discutido também, o perfil e histórico de cada instituição que tiveram papel relevante nesse processo e de como o tema das sementes é incorporado por essas entidades e seus pesquisadores, gestores e professores na sua relação com o projeto específico do MPA de soberania alimentar e genética. Por fim, é apresentada uma avaliação do processo,

\footnotetext{
${ }^{127}$ A lei no 11.346 criou a Lei Orgânica de Segurança Alimentar e Nutricional (Losan), composta pelo Sistema Nacional de Segurança Alimentar e Nutricional (Sisan), cujo Conselho Nacional de Segurança Alimentar e Nutricional (CONSEA) faz parte. Este conselho está composto por 2/3 de membros provenientes da sociedade civil e 1/3 de membros do governo (IPEA, 2012). O MPA ocupou um dos assentos destinados a sociedade civil nas últimas gestões, desde 2007.
} 
considerando os aspectos dimensionais da soberania alimentar relacionados com as questões políticas, territoriais e tecnológicas. 


\section{CONCLUSÃO}

Esta tese defendeu e mostrou com evidências que o Movimento dos Pequenos Agricultores-MPA-Brasil, coordenado pelo MPA-Santa Catarina por meio da cooperativa Oestebio, desenvolveu a experiência de massificação de sementes crioulas e varietais a partir de uma ampla articulação de ações, alianças com instituições e outros movimentos, influenciando e sendo influenciado por políticas públicas e ações do Estado para constituir a soberania genética com base no projeto de soberania alimentar.

Primeiramente, envolveu experiências anteriores com a coleta, recuperação e produção de sementes crioulas conduzida pelos guardiões de sementes; posteriormente, constituiu uma ampla rede de multiplicadores, abrangendo, especialmente, o território do estado de Santa Catarina, mas também municípios dos estados do Paraná e Rio Grande do Sul. Ao mesmo tempo, construiu uma rede de apoiadores no campo da ciência, agregando instituições de pesquisa e ensino para estruturar do ponto de vista técnico-científico e institucional, o processo de produção de sementes e sua institucionalização e por fim, atuou simultaneamente na implementação, efetivação e reelaboração de diversas políticas públicas, sobretudo, influenciou a constituição do PAA Sementes, no contexto do PAA, na perspectiva de estruturar, apoiar e constituir o espraiamento da experiência de soberania alimentar e genética nesses territórios.

Assim, eles teceram uma longa teia de relações, articulando os campos político, econômico, científico e socioambiental, ancorado no diálogo constante nos diferentes níveis local, regional, nacional e internacional - constituindo uma experiência portadora da soberania alimentar dentro dos limites atuais da economia política contemporânea cujas aprendizagens tecerei considerações a seguir.

É importante ressaltar que, independentemente de quem sejam os atores camponeses, pesquisadores, gestores, professores - a pauta vem sendo ditada sempre de fora para dentro, há pouco espaço para autonomia, o que não impede a resistência. Contudo, são as agendas internacionais, sejam da FAO, das agências financeiras internacionais, multinacionais do setor de sementes, regimes internacionais, envolvendo diferentes temáticas que ordinariamente vem restringindo as liberdades de acesso aos recursos em todos os níveis materiais, sociais, culturais e ambientais - produzindo os conflitos distributivos socioambientais e perpetuando as injustiças sociais. Como falar em soberania alimentar em um sistema de restrições, apropriações e expropriações? 
Resistir é um verbo que segue sendo conjugado. O MPA construiu um legado importante, exemplo de experimentação social que considera os modos de existência camponesa e suas diversidades de formas de existir nos diferentes ambientes porque há uma diversidade de constrangimentos, de conflitos históricos e atuais, de invenções e elaborações nos diversos campos, nesses contextos, a soberania segue sendo uma necessidade do ponto de vista socioambiental e política.

Do ponto de vista das empresas públicas de pesquisa assim como fazem planejamento com metas claras de alcance tem que fornecer incentivos, propor políticas de alcance de curto, médio e longo prazo que envolvam a conservação in situ on farm, dialogando não apenas com os regimes internacionais com relação aos temas, mas sobretudo com as políticas públicas nos âmbitos locais, estaduais e federais a luz das experiências que os camponeses vem instituindo ao longo do tempo. Esse mapeamento é um passo importante para estruturar um processo nesse nível. Há um claro ativismo internacional e ações tímidas no nível local o que pode ser confirmado pela ausência de documentos orientadores sobre essa temática.

Do ponto de vista político, a experiência do MPA incorpora-se a um novo momento do movimento social brasileiro na criação de alternativas práticas que vincule o acesso às políticas públicas aos processos produtivos locais e à produção de mudanças socioambientais, neste caso em particular, numa perspectiva de soberania alimentar. O movimento transita entre o espaço reivindicatório para o de produtor de políticas públicas que impactam a vida real de sua base, ocupando diversos espaços, anteriormente, fragilmente, ocupado pelo Estado e por atravessadores.

Para a inserção nas políticas públicas houve um intenso processo de aprendizagens, não apenas sobre o funcionamento das leis e normas que regem o funcionamento do Estado, mas sobretudo, da administração e do moderno mundo dos softwares e sistemas modernos de gestão como, por exemplo, o MOC - Manual de Operações da CONAB que apresenta passo a passo toda a burocracia envolvida na operacionalização das compras institucionais. Cada uma das políticas possuía seu próprio formato de operação que demandava tanto qualificação quanto disponibilidade de tempo no envolvimento de toda a rede espalhada no território com suas lógicas de vida e de organização diferenciadas. Esse foi um dos maiores desafios na operacionalização desse processo. Há tempos e lógicas diferentes entre o mundo rural e a burocracia estatal.

O conhecimento de algumas instituições por dentro na medida em que muitas instituições são quase inacessíveis para os camponeses, especialmente, às investidas de conhecimento científico, instituições de pesquisa e universidades. O trabalho com essas 
instituições, muitas vezes, estão restritos a poucos membros da instituição e não há diálogos entre as diferentes equipes que trabalham, inclusive, no mesmo universo. Os camponeses e suas organizações não conhecem o funcionamento, os projetos e as possibilidades técnicas disponíveis. Assim, esse projeto abriu perspectivas de trabalho em rede, inclusive para as próprias instituições envolvidas e suas equipes.

A apropriação do funcionamento do setor de sementes por dentro tanto do sistema formal operado pelo MAPA, como também a demanda dos diversos setores da sociedade desde a sociedade civil, o governo federal nas suas diversas instâncias, os governos estaduais, bem como camponeses, povos indígenas e populações tradicionais. Há um mercado tanto institucional quanto da produção orgânica crescente no país para abastecer e constituir alianças importantes para que a soberania genética se fortaleça do ponto de vista territorial, incluindo aí, os territórios indígenas, quilombolas e de comunidades tradicionais. Compartilhar essas aprendizagens é um passo preponderante para que mais grupos sociais possam se apropriar dos conhecimentos. Isso porque o movimento construiu não apenas uma capacidade discursiva para influenciar as políticas públicas, mas uma capacidade técnicocientífica, um saber-fazer prático e teórico de produção por dentro dessas políticas.

Considero que a estratégia no seu conjunto abarca diferentes etapas que inclui o trabalho de conservação ativo com as sementes crioulas que é realizado pelos camponeses sem o apoio do Estado, mas que precisa urgentemente ser reconhecido e valorizado por uma política pública que integre tanto a remuneração desses camponeses quanto um processo de formação para ampliar a rede de guardiões e mantenedores existentes. Este é um entendimento tanto dos camponeses e do movimento, quanto de pesquisadores que colaboram com este esforço de elaboração de uma estratégia socioambiental na conservação do patrimônio genético nacional. Esse é um trabalho que vem sendo desenvolvido pelas famílias camponesas e, muito fortemente, pelas mulheres e reivindicado como um tipo de serviço ambiental.

As casas de sementes também é uma estratégia de pouca expressividade na região oeste de Santa Catarina, mas que deve ser intensificado porque cumpre um papel importante de troca entre os agricultores. Necessita de uma gestão coletiva e por isso, as organizações sociais desempenham um papel importante não apenas na divulgação, mas especialmente na coordenação e gestão do processo como é realizado pelo sindicato de agricultores familiares do município de Anchieta com sua casa de sementes e seu horto medicinal.

A usina de beneficiamento é importante nessa estratégia do ponto de vista territorial, na medida em que representa uma modalidade estruturante no enfrentamento ao avanço das 
empresas sobre o patrimônio genético do país e a proliferação do monocultivo transgênico e híbrido, nas paisagens da agricultura brasileira. A UBS é importante para abastecer camponeses que vivenciam a escassez diante de situações climáticas desfavoráveis (secas extremas e prolongadas ou enxurradas/enchentes), cada vez mais recorrentes no Brasil; os programas de governos municipais, estaduais e federais com o uso de variedades convencionais e aquelas de polinização aberta, no caso da cultura do milho, provenientes da pesquisa pública e da pesquisa que os próprios camponeses desenvolvem, além das crioulas que apresentem ampla capacidade de adaptação em diferentes ambientes. Além disso, tem o espaço no mercado dos produtos de orgânicos, vegetais e animais, que tem processos de certificação que os transgênicos estão excluídos. Do ponto de vista de instituir e recuperar a soberania genética e alimentar essas três estratégias representam no conjunto a constituição de um território livre de transgênicos aliado a um trabalho de conservação e preservação do patrimônio genético nacional. E, do ponto de vista econômico, uma alternativa de mercado importante para a agricultura camponesa no país.

Por outro lado, há debates diversos no interior do movimento sobre se a estratégia de massificação em virtude de ter que ser operado por um conjunto de tecnologias centrado em modelos convencionais de escala de produção, o que os obriga a reproduzir um modelo próximo ao convencional, mesmo que a cooperativa não trabalhe estritamente centrada no lucro, mas o processo per se, excluí, classifica e reproduz desigualdades sociais e econômicas, na medida em que a economia convencional centrada nos custos de produção e em padrões de qualidade questionáveis, ainda tem peso relevante no processo, vide que o conjunto das regulamentações é produzido para o contexto do sistema do agronegócio sementeiro.

A experiência mostra que as políticas públicas são fundantes para que camponeses com acesso a poucos recursos, ou seja, terra e capital, possam ser inseridos, mesmo tendo um forte movimento social como suporte para inclúi-los, pois como mostram as evidências o MPA efetivamente operou para que esses camponeses acessassem as políticas em curso no país - crédito, seguro agrícola, assistência técnica e de compras governamentais - o que lhes garantiu poder de mercado. Sozinhos, isolados, esses camponeses não alcançariam inserção, seja na política pública, no mercado e na rede que se estabeleceu. Por isso fortalecer os movimentos sociais continua a ser preponderante para a continuidade dos camponeses no território.

Por fim, nessa estratégia o território importa e por isso massificar representa a ocupação do espaço geográfico, a paisagem do lugar, disputá-la com o agronegócio e instituir efetivamente, novas formas de ocupação, isso expressa a soberania sobre o território. Quais os 
aprendizados do ponto de vista da soberania alimentar? A soberania é uma responsabilidade de um país. É certo que o movimento mostrou um caminho, mas precisa de muitas mãos, não só para fazer acontecer, mas para pensar formas diferenciadas e diversas para operar um processo que é político. A soberania alimentar pressupõe novas formas de se relacionar com o meio e, portanto, precisa de instrumentos técnicos para que isso aconteça. Nesse sentido, a ciência também precisa ser reformulada a luz dos problemas que a própria experiência aponta como limites e constrangimentos para a continuidade da experiência nessa perspectiva de soberania genética e territorial e justiça ambiental.

Há uma lacuna que necessita ser ocupada pela pesquisa pública, em particular pela Embrapa e pelo SNPA, que diz respeito ao mapeamento das experiências em curso implementadas por diferentes movimentos sociais e grupos de camponeses espalhadas pelo país, visando constituir uma rede nacional focada na soberania alimentar e genética. Urge institucionalizar um programa nacional de conservação ativo da agrobiodiversidade em diálogo com essas experiências, reforçando os processos e percursos formativos focados no fortalecimento e expansão das redes de famílias guardiães.

Além disso, identificar os impactos da territorialização dos transgênicos tanto do ponto de vista da ocupação espacial quanto dos efeitos socioambientais presentes e futuros, em especial do ponto de vista da contaminação, direta ou indireta, de recursos genéticos e de outros recursos como por exemplo, solo e água e na própria saúde dos consumidores. Trata-se da soberania de um país. A ciência deve fornecer conhecimentos e informações para subsidiar não apenas o governo, mas sobretudo a sociedade para que essa possa tomar as melhores decisões. 


\section{REFERÊNCIAS BIBLIOGRÁFICA}

ABEL, N.; BLAIKIE, P. M. Elephants, people, parks and development: the case of the Luangwa Valley, Zambia. Environmental Management, vol. 10, $\mathrm{n}^{\mathrm{o}}$ 6, pg. 735-751.

ABRASEM. Estatística da produção. Anuário Abrasem, Brasília, DF, 2015. 110p

ABRASEM. Estatística da produção. Anuário Abrasem, Brasília, DF, 2016. 124p.

ACSELRAD, H.; MELLO, C. C. A. e BEZERRA, G. N. O que é justiça ambiental. Rio de Janeiro: Garamond, 2009. 156p.

ACSELRAD, H. Ambientalização das lutas sociais - o caso do movimento por justiça ambiental. Estudos Avançados. Vol. 1, n1. Dossiê Teorias socioambientais. São Paulo: IEA, 2010, pg. 103-119.

ACTION GROUP ON EROSION, TECHNOLOGY AND CONCENTRATION. Cuaderno, $\mathrm{n}^{\circ}$ 115, Grupo ETC - Diciembre 2015 - Enero 2016. Disponível em: http://www.etcgroup.org/sites/www.etcgroup.org/files/files/breaking_bad_spano_format 10feb16.pdf. Acesso em 28.03.2016.

ALVAREDO, F.; CHANCEL, L.; PIKETTY, T.; SAEZ, E.; ZUCMAN, G. (Cood.). World Inequality Report 2018. WID. World Working, 2017.

ALTAFIN, I. Reflexões sobre o conceito de agricultura familiar. 2007. 23p. Disponível em: http://www.enfoc.org.br/web/arquivos/documento/70/f1282reflexoes-sobre-o-conceitode-agricultura-familiar---iara-altafin---2007.pdf. Acesso em: 23.05.2016.

ANGUELOVSKI, I. and MARTÍNEZ-ALIER, J. The 'Environmentalism of the Poor' revisited: Territory and place in disconnected glocal struggles. Ecological Economics, 102, pg. $167-176$, 2014. Disponível em: http://www.sciencedirect.com/science/article/pii/S0921800914001141. Acesso em 12.04.2016.

ASSOUAD, L.; CHANCEL, L. e MORGAN, M. Extreme inequality: evidence from Brazil, India, the Middle East and South Africa. WID. World Working, Paper $\mathbf{N}^{\circ}$ 2018/4, 2018.

BECKER, B. K. Significância contemprânea da fronteira: Uma interpretação geopolítica a partir da Amazônia brasileira. In AUBERTIN, Catherine (org.). Fronteiras. Brasília: Editora Universidade de Brasilia (UNB); Paris: ORSTOM 1988. p. 60-89.

BEVILAQUA, G. A. P.; ANTUNES, I. F.; BARBIERI, R. L.; SCHWENGBER, J. E.; SILVA, S. D. A.; LEITE, D. L.; CARDOSO, J. H. Agricultores guardiões de sementes e ampliação da agrobiodiversidade. Cadernos de Ciência \& Tecnologia, Brasília, 2014, v. 31, n. 1, p. 99-118.

BLAIKIE, P. M. The political economy of soil erosion in developing countries. Longman Development Series, No. 1, Longman, London, 1985, pp. 188. 
BLAIKIE, P. M.; BROOKFIELD, H. Land degradation and society. Methuen, London and New York, 1987.

BLAIKIE, P. M. Changing Environments or Changing Views? A Political Ecology for Developing Countries. Geography, Vol. 80, No. 3, 1995, pp. 203-214.

BLAIKIE, P. M.; MULDAVIN, J. The Politics of Environmental Policy with a Himalayan Example. Asian Pacific Issues, No 74, 2004, East-West Center, Hawaii.

BIZZO, H. R.; HOVELL, A. M.; REZENDE, C. M. Óleos essenciais no Brasil: aspectos gerais, desenvolvimento e perspectivas. Quim. Nova, Vol. 32, No. 3, 588-594, 2009. Disponível em: http://www.scielo.br/pdf/qn/v32n3/a05v32n3.pdf. Acesso em 12.11.2017.

BOECHAT, C. A.; PITTA, F. T.; TOLECO, C. A. Land Grabbing e crise do capital: possíveis intersecções dos debates. GEOgraphia, Niterói, Universidade Federal Fluminense, Vol.19, No 40, 2017, pg. 75-91.

BOMBARDI, L. M. Intoxicação e morte por agrotóxicos no Brasil: a nova versao do capitalismo oligopolizado. In: Boletim Dataluta. NERA - Núcleo de Estudos, Pesquisas e Projetos de Reforma Agrária. Presidente Prudente, 2011, p. 1-21. Disponível em:http://www2.fct.unesp.br/grupos/nera/artigodomes/9artigodomes_2011.pdf

Violência silenciosa: o uso de agrotóxicos no Brasil. Anais do VI Simpósio Internacional de Geografia Agrária: Universidade Federal da Paraíba. João Pessoa, 2013.

Geografia do uso de agrotóxicos no Brasil e conexões com a União Européia. São Paulo: FFLCH-USP, 2017.

BRASIL. Ministério da Agricultura Pecuária e Abastecimento. Guia de inspeção de campos para produção de sementes. Ministério da Agricultura Pecuária e Abastecimento. Secretaria de Defesa Agropecuária. - 3 ${ }^{\mathrm{a}}$. ed. revisada e atualizada - Brasília : Mapa/ACS, 2011. 41 p.

BRAYANT, R.; GOODMAN, M. K. A pioneering reputation: Assessing Piers Blaikie's contributions to political ecology. Geoforum 39, 2008, 708-715.

BUAinAin, A. M.; SABBAto, A. e GUANZIROLI, C. E. Agricultura Familiar: Um estudo de Focalização Regional. Disponível em: http://www.sober.org.br/palestra/12/09O437.pdf. Acesso em 30/04/2014.

CADONÁ, C. V. Movimento dos Pequenos Agricultores - MPA: o novo nasce das estradas. Dissertação (Mestrado em Educação) - Programa de Pós-Graduação em Educação nas Ciências. Ijuí: UNIJUÍ, 2004. 283p.

CALDART, R. S.; PEREIRA, I. B.; ALENTEJANO, P. e FRIGOTTO, G. Dicionário da Educação do Campo. Rio de Janeiro, São Paulo: Escola Politécnica de Saúde Joaquim Venâncio, Expressão Popular, 2012.

CANCI, A. Sementes crioulas: construindo soberania na mão do agricultor, a experiência de Anchieta (SC). São Miguel do Oeste: Mclee, 2002, 161p. 
CAPELLESSO, A. J. Crédito e seguro da agricultura familiar: políticas públicas de apoio à sustentabilidade ou de subsídio a sistemas produtivos de baixa eficiência? Florianopolis, SC: Universidade Federal de Santa Catarina: Centro de Ciências Agrárias Programa de Pós-graduação em Agroecossistemas, 2016, 357p. Tese (doutorado).

CAPISTRANO, M.C. Do Centro Agropecuário a Centro de Ciências Agrárias. In: NECKEL, R.; KUCHLER, D. C. UFSC 50 anos: trajetórias e desafios. Florianópolis: UFSC, 2010. 48p.

CARTACAPITAL. A Syngenta e o negócio da China. Economia: Agricultura, 12.02.2016. Disponível em: http://www.cartacapital.com.br/economia/syngenta-monsanto-china-tudo-aver-com-voce-no-brasil. Acesso em 23.05.2016.

CARVALHO, H. M. O camponês, guardião da agrobiodiversidade. Curitiba, 2013. 16p.

CASTREE, N. Commodifying what nature? Progress in Human Geography, 27, 3, 2003, pp. 273-297.

CHAIFETZ, A. and JAGGER, P. 40 Years of dialogue on food sovereignty: a review and a look ahead. Global Food Security 3, pg. 85-91, 2014. Disponível em: http://www.sciencedirect.com/science/article/pii/S2211912414000121. Acesso em: 12.02.2016.

COMPANHIA NACIONAL DE ABASTECIMENTO. MANUAL DE OPERAÇÕES DA CONAB. MOC Título 86. Brasília/DF: 2015, 14p. Disponível em: http://www.conab.gov.br/conabweb/moc.php. Acesso em 03.12.2017.

COOPERATIVA DE TRABAJO PARA LA COMUNICACIÓN. Producir semillas criollas para alimentar al mundo. 21/02/2014. Disponível em: http://www.8300.com.ar/2014/02/21/producir-semillas-criollas-para-alimentar-al-mundo/. (Acesso em 02/03/2016).

CORDEIRO, A.; PEREZ, J. e GUAZZELLY, M. J. Impactos potenciais da tecnologia Terminator na produção agrícola: depoimentos de agricultores brasileiros. Florianópolis/SC: Grupo ETC, Centro Ecológico, 2007, 39pg.

COSTA, F. M. Diversidade genética e distribuição geográfica: uma abordagem para a conservaçãoo on farm e ex situ e o uso sustentável dos recursos genéticos de milho do Oeste de Santa Catarina. Florianópolis, SC, 2013, 212p. Universidade Federal de Santa Catarina. Centro de Ciências Agrárias. Pós-graduação em Recursos Genéticos Vegetais. Dissertação (mestrado).

DA SILVA, D. M. O. B.; FILHO SCHMIDT, R.; AGUIAR, M. B. M.; COSTA, F. B. PRONAF: uma avaliação da distribuição regional dos contratos de crédito e seus impactos sobre o desenvolvimento rural do Nordeste brasileiro. Revista OKARA: Geografia em debate. João Pessoa, 2017, v.11, n.2, p. 376-396.

DELGADO, G. A questão agrária hoje. In: MATTEI, Lauro (org.) Reforma Agrária no Brasil: trajetória e dilemas. Insular, 2017, pg. 93-108. 
DEMO, P. Metodologia científica em ciências sociais. São Paulo: Atlas, 1989. 287p.

EDELMAN, M.; WEIS, T.; BAVISKAR, A.; BORRAS JR, S. M.; HOLT- GIMÉNEZ, E.; KANDIYOTI, D. and WENDY, W. Introduction: critical perspectives on food sovereignty. The Journal of Peasant Studies. Vol. 41, no 6, 911-931pg, 2014. Disponível em http://dx.doi.org/10.1080/03066150.2014.963568. Acesso em: 12.02.2016.

EMBRAPA. SEG - Sistema Embrapa de Gestão. Manual Orientador sobre o SEG. Brasília: Departamento de Pesquisa e Desenvolvimento/EMBRAPA, 2003, 25pg.

Visão 2014-2034 : o futuro do desenvolvimento tecnológico da agricultura brasileira. Brasília, DF : Embrapa, 2014, 194 p.

Governança de Arranjos na Embrapa. Brasília: Departamento de Pesquisa e Desenvolvimento-DPD/EMBRAPA, 2015a, 12pg.

Governança de Portfólio na Embrapa. Brasília: Departamento de Pesquisa e Desenvolvimento-DPD/EMBRAPA, 2015b, 12pg.

Plano Gerencial da Embrapa: 2016-2018. Brasília, 2016, 28p.

$140 \mathrm{p}$.

Embrapa em Números. Brasília/DF: Embrapa/Secretaria de Comunicação, 2017a,

. Revisão da Estrutura Organizacional da Embrapa - Proposta para Análise do Conselho de Administração - Consad. Nota Técnica. Brasília: Embrapa, 2017b, 23p.

Resolução do Conselho de Administração, no 164. Ano XLIII, BCA no 43, de 02.10.2017, 2017c.

Resolução do Conselho de Administração, no 165 . Ano XLIII, BCA $\mathbf{n}^{\mathbf{0}}$ 43, de 02.10.2017, 2017d.

EPAGRI. Números da agropecuária catarinense - 2017. Florianópolis, SC, 2017. 75p. (Epagri. Documentos, 277).

ESPÍNDOLA, M. A.; NODARE, E. S. As estiagens no oeste catarinense sob a perspectiva da História Ambiental. In: Anais do $2^{\mathbf{0}}$ Simpósio em História Ambiental e Migrações. Florianopolis/SC, 2012, p. 2691-2715.

FAIRHEAD, J.; LEACH, M.; SCOONES, I. Green grabbing: a new appropriation of nature. The Journal of Peasant Studies, 39:2, 237-261, 2012.

FARIA, L. R, de: 'Uma ilha de competência: a história do Instituto de Química Agrícola na memória de seus cientistas'. História, Ciências, Saúde — Manguinhos, III (3):51-74 Mar.Jun. 1997.

FERNANDES, B. M.; WELCH, C. A.; GONÇALVES, E. C. Políticas fundiárias no Brasil: uma análise geo-histórica da governança da terra no Brasil. In: Framing the Debate Series, nº 2, ILC, Roma, 2012. 
FERNANDES, B. M. Políticas públicas, questão agraria e desenvolvimento territorial rural no Brasil. In: Grisa, Catia e Schneider, Sergio (org.)., 2015. Políticas públicas de desenvolvimento rural no Brasil. Porto Alegre: Editora da UFRGS, pg. 381 - 400.

FERNANDES, B. M. Questões teóricas e políticas de um governo em disputa: a reforma agrária no governo Dilma. In: MATTEI, Lauro (org.) Reforma Agrária no Brasil: trajetória e dilemas. Insular, 2017, pg. 247-267.

FERNANDES, G. B. Sementes crioulas, varietais e orgânicas para a agricultura familiar: da exceção legal à política pública. In: SAMBUICHI, R. H. R.; MOURA, I. F.; MATTOS, L. M.; ÁVILA, M. L.; SPÍNOLA, P. A. C.; SILVA, A. P. M. A política nacional de agroecologia e produção orgânica no Brasil: uma trajetória de luta pelo desenvolvimento rural sustentável - Brasília : Ipea, 2017, pg. 327- 357.

FOOD AND AGRICULTURE ORGANIZATION OF THE UNITED NATIONS and ITPS. Status of the World's soil resources(SWSR). Main Report. Food and Agriculture Organization of the United Nations and Intergovernmental Technical Panel on Soils, Rome, Italy, 2015.

FOOD AND AGRICULTURE ORGANIZATION OF THE UNITED NATIONS. The state of the World's plant genetic resources for food and agriculture. Rome: FA0, 1997, 540p. Disponível em: http://www.fao.org/3/a-w7324e.pdf. Acesso em 12.11.2017.

\section{FÓRUM MUNDIAL PELA SOBERANIA ALIMENTAR. DECLARAÇÃO DE NYÉLÉNE. 2007.2 Disponível em: http://www.cidac.pt/files/5514/2539/9126/Declarao_de_Nylny.pdf. Acesso em 12/02/2016.}

FRANCA-NETO, J. B.; OLIVEIRA, M.J. Seed technology research in Brazil: evolution and perspective. Sci. agric., 55 (vol. Spec.): 8-18; 1998.

FURTADO, C. Formação econômica do Brasil. São Paulo: Companhia Editora Nacional, 2003, 256p.

GASTAL, M. L. Macroprograma 6 da Embrapa: Apoio ao desenvolvimento da agricultura familiar e à sustentabilidade do meio rural. Brasília/DF: DPD/Embrapa, s/d.

GERALDI, I. O. A pós-graduação em genética e melhoramento de plantas no Brasil: diagnóstico e prioridades. Revista Brasileira de Pos Graduação. Brasília, v. 4, n. 7, p. 8798, julho de 2007. Disponível em: http://dx.doi.org/10.21713/2358-2332.2007.v4.121. Acesso em 03.12.2017.

GILLES, F.; ZANONI, M.; BRACK, P.; KAGEYAMA, P.; NODARI, R. O. Coexistência: o caso do milho. Brasília: MDA, 2009. 56p.

GIRARDI, G. e DECONTO, J. G. (coord.). Aquecimento global e a nova geografia da produção agrícola no Brasil. Campinas/SP: Embrapa e Unicamp. 2008, 83p.

GOHN, Maria da Glória. Direitos sociais:avanços e recuos da cidadania. Instituto Humanitas Unisinos. Ano II, No. 203, 2014. 
GOODMAN, M. 2004. Reading fair trade: political ecological imaginary and the moral economy of fair trade foods. Political Geography, 2004, 23 (7), 891-915.

GRISA, C. Projetos estratégicos e ações para o desenvolvimento territorial: uma análise do PRONAT e do Programa Territórios da Cidadania. . In: MIRANDA, C.; TIBURCIO, B. (Org.). Políticas de desenvolvimento territorial e enfrentamento da pobreza rural no Brasil. Brasília: IICA, 2013 (Série desenvolvimento rural sustentável; v.19), pg. 148-175.

Políticas públicas para a agricultura familiar no Brasil: produção e institucionalização das ideias. (Tese de doutorado). Universidade Federal Rural do Rio de Janeiro/UFRRJ, 2012, .

GRISA, C. e PORTO, S. I. Dez anos de PAA: as contribuições e os desafios para o desenvolvimento rural. In: GRISA, C.; SCHNEIDER, S. (org.). Políticas públicas de desenvolvimento rural no Brasil. Porto Alegre: Editora da UFRGS, 2015, pg 155 - 180.

GRISA, C.; SCHINEIDER, S. Três gerações de políticas públicas para a agricultura familiar e formas de interação entre Estado e Sociedade no Brasil. Brasília: Revista Economia e Sociologia Rural, 2014, vol. 52, supl. 1. Disponível em: http://www.scielo.br/scielo.php?script=sci_arttext\&pid=S0103-20032014000600007. Acesso em 22.12.2016.

GREENPEACE. 02/2015. Disponível em: http://www.greenpeace.org/brasil/pt/Noticias/Para-ONU-agricultura-convencional-naocombate-a-fome/

HANJRA, M. A. and QURESHI, M. E. Global water crisis and future food security in an era of climate change. Food Policy 35, 365-377pg, 2010. Disponível em: http://bwl.univie.ac.at/fileadmin/user_upload/lehrstuhl_ind_en_uw/lehre/ss11/Sem_Yuri/Wat er-food.pdf. Acesso em: 03.02.2016.

HARVEY, M. and PILGRIM, S. The new competition for land: Food, energy and climate change. Food Policy 36, 540-551pg, 2011. Disponível em: http://www.sciencedirect.com/science/article/pii/S0306919210001235. Acesso em: 03.02.2016.

HECHT, S. B. Environment, development and politics. World Development, 13, 1985, pg. 663-684.

HEINZE, B.C.L. A importância da agricultura irrigada para o desenvolvimento da região nordeste do Brasil. Brasília, 2002. 70p. Monografia (Curso MBA em gestão sustentável da agricultura irrigada) Ecobusiness School/FGV.

HIGGINS, A. A War of Words: The Construction of Food Sovereignty in the US \& UK. In: New Castle University: Centre for Rural Economy: Discussion Paper. Series $N^{\circ} 34,23 p g$, 2015. Disponível em: http://www.ncl.ac.uk/cre/publish/discussionpapers/pdfs/DP34.pdf. Acesso: 12.02.2016. 
HOPMA, J. and WOODS, M. Political Geographies of 'Food Security' and 'Food Sovereignty'. Geography Compass. November 2014. Disponível em: www.researchgate.net/publication/268452799. Acesso 12.02.2016.

HURNI, H.; GIGER, M.; LINIGER, H.; STUDER, R. M.; MESSERLI, P.; PORTNER, B.; SCHWILCH, G.; WOLFGRAMM, B. and BREU, T. Soils, agriculture and food security: the interplay between ecosystem functioning and humam well-geing. Current Opinion in Environmental Sustainability. 15: 25-34pg, 2015. Disponível em: http://www.sciencedirect.com/science/article/pii/S1877343515000731. Acesso em 13/02/2016.

INSTITUTO BRASILEIRO DE GEOGRAFIA E ESTATÍSTICA. Censo agropecuário 2006. Rio de Janeiro (RJ): 2006.

Censo agropecuário 2006: Agricultura familiar - resultados preliminares. Rio de Janeiro: IBGE, 2009.

2010 (ver)

INSTITUTO DE PESQUISAS ECONÔMICAS APLICADAS - IPEA. Código Florestal: implicações do PL 1876-99 nas áreas de Reserva Legal. Comunicados do IPEA. Brasília, 2011.

O Conselho Nacional de Segurança Alimentar e Nutricional na visão de seus conselheiros. Relatório de pesquisa. Projeto Conselhos Nacionais: perfis e atuação dos conselheiros. $\quad$ Brasília: $2012 . \quad$ Disponível: http://ipea.gov.br/participacao/images/pdfs/relatoriosconselhos/120409_relatorio_seguranca_a limentar.pdf. Acesso em 12.11.2017.

Sementes crioulas valem ouro. Ano 11 . Edição 81 - 05/10/2014. Disponível em http://www.ipea.gov.br/desafios/index.php?option=com_content \&view=article\&id=3091\&cat $\underline{\mathrm{id}=28 \& \text { Itemid }=39}$. Acesso em 12/03/2016.

INSTITUTO DE PESQUISA E ESTRATÉGIA ECONÔMICA DO CEARÁ - IPECE. Entendendo o índice de Gini. Secretária do Planejamento e Gestão-Governo do Ceará.(sd).

INSTITUTO DO MEIO AMBIENTE E DOS RECURSOS NATURAIS RENOVAVEIS. Agrobiodiversidade e diversidade cultural / MMA - Brasília: MMA/SBF, 2006. 82 p. (Série Biodiversidade, 20)

INSTITUTO NACIONAL DE COLONIZAÇAO E REFORMA AGRARIA. Sistema Nacional de Cadastro Rural. Índice Básico de 2013. Disponível em: http://www.incra.gov.br/sites/default/files/uploads/estrutura-fundiaria/regularizacao-

fundiaria/indices-cadastrais/indices_basicos_2013_por_municipio.pdf. Ultimo acesso em 10.01.2018.

ISAAA. 2016. Global Status of Commercialized Biotech/GM Crops: 2016. ISAAA Brief No. 52. ISAAA: Ithaca, NY.

KELLY, Alice B. Conservation practice as primitive accumulation. Journal of Peasant Studies, 38, $\mathrm{n}^{0} 4$, 2011, pg. 683-701. 
KLOPPENBURG, J. First the seed: The political economy of plant biotechnology, 14922000. Cambridge: Cambridge University Press, $2^{\circ}$ edição, 2004.

Re-purposing the master's tools: the open source seed initiative and the struggle for seed sovereignty. Conference Paper \# 56, Food Sovereignty: A Critical Dialogue International Conference, 2013.

Re-purposing the master's tools: the open source seed initiative and the struggle for seed sovereignty. The Journal of Peasant Studies, 41:6, 2014, 1225-1246.

LAURANCE, W. F.; SAYER, J. and CASSMAN, K. G. Agricultural expansion and its impacts on tropical nature. Trends in Ecology \& Evolution. Vol. 29, n ${ }^{\circ}$ 2, 107 - 116pg, 2014. Disponível em: http://www.sciencedirect.com/science/article/pii/S0169534713002929. Acesso em 02.02.2016.

LEGUIZAMÓN, A. Modifying Argentina: GM soy and socio-environmental change. Geoforum, 2014, Volume 53, pg. 149-160. https://doi.org/10.1016/j.geoforum.2013.04.001. (accessed 02.22.2017).

LONDRES, F. A nova legislação de sementes e mudas no Brasil e seus impactos sobre a agricultura familiar. Rio de Janeiro, jul. 2006. Disponível em www.agroecologia.org.br.

A Associação Biodinâmica e o desafio da produção de sementes de hortaliças. Rio de Janeiro: AS-PTA, 2014, 52 pg.

LOWDER, S. K.; SKOET, J. and RANEY, T. The number, size, and distribution of farms, smallholder farms, and family farms worldwide. World Development. 2016, 14p. Disponível em: http://dx.doi.org/10.1016/j.worlddev.2015.10.041. Acesso em: 12.04.2016.

MACHADO, A. T. Construção histórica do melhoramento genético de plantas: do convencional ao participativo. Revista Brasileira de Agroecologia, 9(1): 35-50 p., 2014.

MACHADO, K. C.; GRASSI, M. T.; VIDAL, C.; PESCARA, I. C.; JARDIM, W. F.; FERNANDES, A. N.; SODRÉ, F. F.; ALMEIDA, F. V.; SANTANA, J. S.; CANELA, M. C.; NUNES, C. R. O.; BICHINHO, K. M.; SEVERO, F. J. R. A preliminar Nationwide survey of the presence of emerging contaminants in drinking and source waters in Brazil. Science of the Total Environment 575, 2016, pg. 138-146.

MARCONDES, T. A agropecuária em Santa Catarina: cenário atual e principais tendências. Revista NECAT - Ano 5, nº 9, 2016, pg 8-38.

MARIANTE, A. S.; SAMPAIO, M. J. A.; INGLIS, M. C. V. (Orgs.). State of the Brazil's Plant Genetic Resources. Second National Report. Conservation and Sustainable Utilization For Food and Agriculture. Brasília/DF, 2009, 163p. Disponível em: http://www.fao.org/docrep/013/i1500e/Brazil.pdf. Acesso em 11.11.2017.

MARTÍNEZ ALIER, J. O ecologismo dos pobres: conflitos ambientais e linguagens de valoração. São Paulo: Cortez, 2007. 379p. 
MARTÍNEZ-ALIER, J.; KALLIS, G.; VEUTHEY, S.; WALTER, M. and TEMPER, L. Social Metabolism, Ecological Distribution Conflicts, and Valuation Languages. Ecological Economics, 70, pg. 153-158, 2010. Disponível em: http://www.sciencedirect.com/science/article/pii/S0921800910003836. Acesso: 12.04.2016.

MARTÍNEZ-ALIER, J. Environmental Justice and Economic Degrowth: An Alliance between Two Movements. Capitalism Nature Socialism, 23:1, pg. 51-73, 2012. Disponível em: http://degrowth.org/wp-content/uploads/2012/11/jma-degrowth-and-ej.pdf. Acesso em: 06.04.2016.

MARTÍNEZ ALIER, J.; TEMPER, L. and DEMARIA, F. Social Metabolism and Environmental Conflicts in India. Indi@logs, Vol. 1, pg. 51-83, 2014a. Disponível em: https://ddd.uab.cat/pub/indialogs/indialogs_a2014v1/indialogs_a2014v1p51.pdf. Acesso em 12.04.2016.

MARTÍNEZ-ALIER, J. The environmentalism of the poor. Geoforum. 54, pg. 239-241, $2014 b$. Disponível em: http://www.sciencedirect.com/science/article/pii/S0016718513000912. Acesso em: 06.04.2016.

MARTÍNEZ-ALIER, J.; ANGUELOVSKI, I.; BOND, P.; DEL BENE, D.; DEMARIA, F.; GERBER, J.F.; GREYL, L.; HAAS, W.; HEALY, H.; MARÍN-BURGOS, V.; OJO, G.; PORTO M.; RIJNHOUT, L.; RODRÍGUEZ-LABAJOS, B.; SPANGENBERG, J.; TEMPER, L.; WARLENIUS, R. and YÁNEZ, I. Between activism and science: grassroots concepts for sustainability coined by Environmental Justice Organizations. Journal of Political Ecology 21, pg. 19-60, 2014c. Disponível em: http://jpe.library.arizona.edu/volume_21/MartinezAlier.pdf. Acesso em 15.04.2016.

MARTINS, J. S. O cativeiro da Terra. 9a ed. São Paulo: Contexto, 2013 (1979).

Os camponeses e a política no Brasil: as lutas sociais no campo e seu lugar nos processos políticos. Petropólis: editora Vozes, 1981.

Impasses políticos dos movimentos sociais na Amazônia. Tempo Social, Revista de Sociologia, USP, São Paulo, 1 (1): 131-148, 1989.

Reforma agrária - o impossível diálogo sobre a História possível. Tempo Social; Rev. Sociol. USP, S. Paulo, 11(2): 97-128, out. 1999 (editado em fev. 2000).

MATTEI, L. A importância do sistema familiar de produção no estado de Santa Catarina. Revista NECAT - Ano 5, n9, 2016, pg 3-7.

(org.) Reforma agrária no Brasil: Trajetórias e dilemas. Insular, 2017, 298p.

MAZURKIÉVICZ, J. Influência das etapas do beneficiamento na qualidade fisiológica efísica de sementes de milho (Zea Mayz, L.). Florianopolis (SC): Universidade Federal de Santa Catarina/Centro de Ciências Agrarias/Departamento de Fitotecnia, 2011, 54p. Monografia].

MCAFEE, K. Selling Nature to Save It? Biodiversity and the Rise of Green 
Developmentalism. Environment and Planning D: Society and Space, 1999, 17(2): 133154.

MINISTÉRIO DO DESENVOLVIMENO AGRÁRIO. Agricultura Familiar no Brasil e o Censo Agropecuário 2006. Brasília: 2009.

MOHAI, P.; PELlOW, D. E ROBERTS, T. Environmental justice. Annual Review of Environment and Resources. 2009, 34, 405-430p.

MOREIRA, G. C.; TEIXEIRA, E. C. Política pública de pesquisa agropecuária no Brasil. Revista de Política Agrícola. Ano XXIII - No 3 - Jul./Ago./Set. 2014, pg. 5-17. Disponível em: $\quad$ https://ainfo.cnptia.embrapa.br/digital/bitstream/item/114642/1/Politica-publica-depesquisa.pdf. Acesso em 12.12.2017.

MOVIK, S. A fair share? Perceptions of justice in South Africa's water allocation reform policy. Geoforum, 54, pg. 187-195, 2014. Disponível em: http://www.sciencedirect.com/science/article/pii/S0016718513000614. Acesso: 01/04/2016.

MOVIMENTO DOS PEQUENOS AGRICULTORES-MPA. Plano Camponês: por soberania alimentar e poder popular. Auto-sustentação caminhos e conquistas. MPA/ES (Cartilha de Formação). 2009a. 16pg.

MOVIMENTO DOS PEQUENOS AGRICULTORES-MPA/PR. Sementes: Patrimônio dos Povos a serviço da humanidade. Paraná: Associação Paranaense dos Pequenos Agricultores/APPA. (Cartilha de Formação). 2009b. 27 pg.

MOVIMENTO DOS PEQUENOS AGRICULTORES-MPA. Plano Camponês: da agricultura camponesa para toda a sociedade. Coletivo de Formação do Movimento dos Pequenos Agricultore do Espírito Santo, 2012a. (Cartilha do MPA). 31pg.

Plano Camponês: construindo o caminho da roça III. Plano Nacional de Sementes Crioulas rumo a Soberania Genética. ANAC (Associação Nacional de Agricultura Camponesa). 2012b. 69pg.

MOVIMENTO DOS PEQUENOS PRODUTORES/MPA/BRASIL. Políticas públicas de comercialização de sementes crioulas é destaque no $2^{\circ}$ dia de debates do seminário nacional. 12/07/2012c. Disponível em: http://www.mpabrasil.org.br/noticias/politicaspublicas-de-comercializacao-de-sementes-crioulas-e-destaque-no-2o-dia-de-debates. (Acesso em 02/03/2016).

Seminário Nacional de Formação Camponesa inicia suas atividades em Anchieta/SC. 18/04/2012d. Disponível em: http://www.mpabrasil.org.br/noticias/seminario-nacional-de-formacao-camponesa-iniciasuas-atividades-em-anchieta-sc. (Acesso em 02/03/2016).

Seminário Nacional debate experiências de recuperação e melhoramento de sementes crioulas do MPA. 12/07/2012e. Disponível em: http://www.mpabrasil.org.br/noticias/seminario-nacional-debate-experiencias-derecuperacao-e-melhoramento-de-sementes-crioulas. (Acesso 02/03/2016). 
MPA discute os desafios da produção e manutenção das sementes crioulas em seminário. 12/07/2012f. Disponível em: http://www.mpabrasil.org.br/noticias/mpa-discute-os-desafios-da-producao-e-manutencaodas-sementes-crioulas-em-seminario. (Acesso em 02/03/2016).

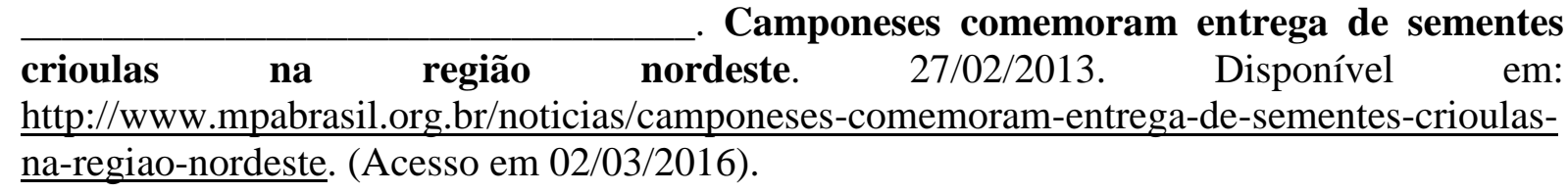

Produzir sementes crioulas para alimentar o mundo. 28/02/2014. Disponível em: http://www.mpabrasil.org.br/noticias/produzir-sementescrioulas-para-alimentar-o-mundo. (Acesso 02/03/2016).

MUNARINI, A. Avaliação de híbridos intervarietais de milho em sistemas de produção camponesa de Santa Catarina. Florianópolis, SC, 2013, 106p. Universidade Federal de Santa Catarina, Centro de Ciências Agrárias, Programa de Pós-graduação em Recursos Genéticos Vegetais. Dissertação (mestrado).

NERLING, D. Qualidade fisiológica de sementes na obtenção de linhagens de e híbridos de milho. Florianópolis, SC, 2017, 153p. Universidade Federal de Santa Catarina, Centro de Ciências Agrárias. Programa de Pós-graduação em Recursos Genéticos Vegetais. Tese (doutorado).

NERLING, D.; MUNARINI, A.; DAL MAS, V.; SANTOS, E.; REGINATTO, C. Conservação e multiplicação de sementes crioulas e varietais pelos camponeses do Movimento dos Pequenos Agricultores de Santa Catarina. In: Cadernos de Agroecologia, Vol 8, No. 2, Nov 2013.

NUNES, J. A. Teoria crítica, cultura e ciência: o(s) espaço e o(s) conhecimento(s) da globalização. In: SANTOS, B. S. A Globalização e as ciências sociais. São Paulo: Cortez, 2011, pg. 301-344.

OLIVEIRA, Ariovaldo Umbelino. A questão da aquisição de terras por estrangeiros no Brasil: um retorno aos dossiês. Agrária, São Paulo: n⿳0 12, 2010, pg.3-113.

OLIVEIRA, M. P. S.; MOCHIZUKI, M. F. A.; GONÇALEZ, A. M. Adendo das Diretrizes para Apresentação de Dissertações e Teses do Programa de Pós-Graduação em Ciência Ambiental (PROCAM-USP). São Paulo: Biblioteca IEE/USP, 2017, 16p.

OXFAM BRASIL. Terrenos da desigualdade: terra, agricultura e desigualdades no Brasil Rural. Informe da Oxfam Brasil, 2016.

OXFAM-Brasil, 2017.

A distância que nos une: um retrato das desigualdades brasileiras.

OXFAM INTERNATIONAL. Ripe for change. Ending human suffering in supermarket supply chains. Report. Oxfam GB, Oxfam House, John Smith Drive, Cowley, Oxford, UK, 2018. 
PELAEZ, Victor Manoel; SILVA, Letícia Rodrigues; GUIMARÃES, Thiago André; DAL RI, Fabiano; TEODOROVICZ, Thomaz. A (des)coordenação de políticas para a indústria de agrotóxicos no Brasil. Revista Brasileira de Inovação, Campinas (SP), 14, número especial, 2015, pg. 153-178.

PELlEGRINO, G. Q.; ASSAD, E. D. e MARIN, F. R. Mudanças Climáticas Globais e a Agricultura no Brasil. Campinas/SP: Revista MultiCiência $n^{\circ} 8$ - Mudanças Climáticas, 139$162 \mathrm{pg}, 2007$.

PEIXOTO, Marcus. Extensão rural no Brasil: uma abordagem histórica da legislação. In: Texto para Discussão 48. Brasília: Consultoria Legislativa do Senado Federal - Centro de Estudos: Texto para Discussão 48, 2008, 50.pg. Disponível em: https://www12.senado.leg.br/publicacoes/estudos-legislativos/tipos-de-estudos/textos-paradiscussao/td-48-extensao-rural-no-brasil-uma-abordagem-historica-da-legislacao.

PENTEADO, M. I. O.; FONTES, R. R.; CAMPOS, F. A. A.; FILHO KEPLER, E. A trajetória do planejamento da pesquisa na Embrapa. Brasília/DF: Cadernos de Ciência \& Tecnologia, v. 31, n. 1, p. 35-60, 2014. Disponível em: https://ainfo.cnptia.embrapa.br/digital/bitstream/item/102132/1/Trajetoria-do-planejamentoda-pesquisa.pdf. Acesso em 11.12.2017.

PEREIRA, C. N.; CASTRO, C. N. O Sistema Nacional de Pesquisa Agropecuária: histórico, estrutura e financiamento. Texto para discussão 2338/Instituto de Pesquisa Econômica Aplicada.- Brasília : Rio de Janeiro : Ipea , 2017, 44p.

PICOLOTTO, E. L. e BRANDENBURG, A. Uma grande oportunidade: o sindicalismo e seus projetos de ecologização da agricultura familiar. Ambiente e Sociedade. São Paulo: v. XVIII. N. 3, p. 1-18, jul-set., 2015.

PISTORIUS, R. Scientists, plants and politics: a history of the plant genetic resources movement. Roma: International Plant Genetic Resources Institute, 1997, 134p.

POLANYI, Karl. A grande transformação: as origens da nossa época. Rio de Janeiro: Elsevier, 2012.

RESOLUÇÃO no 020/2016/SAR/Cederural. Dispõe sobre o Programa Terra Boa - Sementes de Milho ano Safra de 2017. Estado de Santa Catarina. Secretaria de Estado de Agricultura e da Pesca/SAR. Conselho Estadual de Desenvolvimento Rural. Florianópolis/SC, 2016, 5p.

REUNIÃO TÉCNICA ANUAL DE MILHO, 53.; REUNIÃO TÉCNICA ANUAL DE SORGO, 36. Indicações técnicas para o cultivo de milho para o cultivo de milho e de sorgo no Rio Grande do Sul. 2008/2009. Pelotas: 09. Embrapa Clima Temperado, 2008. 169 p.

RIBEIRO, W. C. Meio ambiente: o natural e o produzido. Revista do Departamento de Geografia USP, v. 5, 1991, pg. 29-32. Disponível em: http://www.revistas.usp.br/rdg/article/view/47099/50820. Acesso em: 11.02.2016.

RIBEIRO, W. C.; SANT'ANNA, F. M. Governança da ordem ambiental internacional. In: Wagner Costa Ribeiro (org.). Governança da ordem ambiental internacional e inclusão social. São Paulo: Annablume, 2012, pg. 45-68. 
RIBEIRO, W. C. A ordem ambiental internacional. $3^{\text {a }}$ ed. São Paulo: Contexto, 2014.

Justiça espacial e justiça socioambiental: uma primeira aproximação.

Estudos avançados, vol.31, no.89. São Paulo: 2017. Pg.

ROBBINS, P.; BISHOP, K. M. There and back again: Epiphany, disillusionment, and rediscovery in political ecology. Geoforum 39, 2008, pg. 747-755.

ROBBINS, P. Political Ecology: A Critical Introduction. Blackwell, Oxford, 2011. [selections].

RODRIGUES, C. M. A pesquisa agropecuária federal no período compreendido entre a república velha e o estado novo. Cadernos de difusão de tecnologia, Brasília, v 4(2), maio/ago. 1987a, p129-153.

RODRIGUES, C. M. Gênese e evolução da pesquisa agropecuária no Brasil: da instalação da corte ao início da república. Cadernos de difusão de tecnologia, Brasília, v 4(1), jan/abr. 1987b, p. 21-38.

RODRIGUES, C. M. A pesquisa agropecuária no período pós-guerra. Cadernos de difusão de tecnologia, Brasília, v 4(3), set/dez. 1987c, p. 205-254.

SAMPAIO JÚNIOR, P. A. Notas críticas sobre a atualidade e os desafios da questão agrária. In: MATTEI, Lauro (org.) Reforma Agrária no Brasil: trajetória e dilemas. Insular, 2017, pg. 109-159.

SANTILLI, J. Agrobiodiversidade e direitos dos agricultores. São Paulo: Peirópolis, 2009. $519 \mathrm{p}$.

SANTONIERI, L. R. Agrobiodiversidade e conservação ex situ: reflexões sobre conceitos e práticas a partir do caso da Embrapa/Brasil. Campinas, SP. Universidade Estadual de Campinas. Instituto de Filosofia e Ciências Humanas, 2015, 503p. Tese (doutorado).

SANTONIERI, L. R. e BUSTAMANTE, P. G. Conservação ex situ e on farm de recursos genéticos: desafios para promover sinergias e complementaridades. Boletim do Museu Paraense Emílio Goeldi. Ciências Humanas, v. 11, n. 3, p. 677-690, set.-dez. 2016.

SANTOS, B. S. e MENESES, M. P. Para além do pensamento abissal: das linhas globais a uma ecologia de saberes. In: Epistemologias do Sul. São Paulo: Cortez, pg. 31-83, 2010.

SANTOS, T. A teoria da dependência. Rio de Janeiro: Civilização Brasileira, 2000. 175p.

SAUER, Sérgio; FRANÇA, Franciney Carreiro. Código florestal, função social da terra e soberania alimentar. Caderno CRH, Salvador, v. 25, n.85, pg. 285-307, 2012.

SAUER, Sérgio; BORRAS JÚNIOR, Saturnino. 'Land grabbing' e 'Green grabbing': uma leitura da 'corrida na produção acadêmica' sobre a apropriação global de terras. CampoTerritório: revista de geografia agrária. Edição especial, pg. 6-42, 2016. 
SCHENKELAARS, P.; VRIEND, H.; KALAITZANDONAKES， N. Drivers of Consolidation in the Seed Industry and its Consequences for Innovation. Commission on Genetic Modification (COGEM), 2011.

SECRETARIA DE ESTADO DE AGRICULTURA E DA PESCA-SAR. Programa Terra Boa - Sementes de Milho ano de 2017. Resolução $n^{\circ}$ 020/2016/SAR/Cederural. Santa Catarina, 2016.

SECRETARIA ESPECIAL DA AGRICULTURA FAMILIAR E DO DESENVOLVIMENTO AGRÁRIO. Seguro da agricultura familiar cobre mais de 150 culturas. 10 de abril de 2017. http://www.mda.gov.br/sitemda/noticias/seguro-da-agriculturafamiliar-cobre-mais-de-150-culturas (Acesso em 03.12.2017).

Seguro da agricultura familiar: novo limite de cobertura. 14 de Março de coberturas. (Acesso em 03.12.2017).

SHIVA, V. Monoculturas da mente: perspectivas da biodiversidade e da biotecnologia. São Paulo: Gaia, 2003. 239 p.

SILVA, A. J. A política fundiária do Regime militar: legitimação privilegiada e grilagem especializada (Do instituto de Sesmaria ao Estatuto da Terra). São Paulo: FFLCH-USP, 1997, 414p. Tese (Doutorado em Sociologia) - Universidade de São Paulo, 1997.

SILVA, J. A. A.; NOBRE, A. D.; MANZATTO, C. V.; JOLY, C. A.; RODRIGUES, R. R.; SKORUPA, L. A.; NOBRE, C. A.; AHRENS, S.; MAY, P. H.; SÁ, T. D. A.; CUNHA, M. M. L. C.; RECH FILHO, E. L. O Código Florestal e a Ciência - Contribuições para o Diálogo. São Paulo: Sociedade Brasileira para o Progresso da Ciência, SBPC; Academia Brasileira de Ciências, ABC. 2011. 124p.

SILVA, M. L. T. Contribuição ao debate do Plano Camponês - MPA. Disponível em: http://www.mpabrasil.org.br/biblioteca/textos-artigos/contribuicao-ao-debate-do-planocampones-0 . Acesso 12/03/2016.

SILVA JUNIOR, J. J. Transformações da agricultura e pesquisa agrícola no Brasil. Campina: SP, 2017, 189p. Universidade Estadual de Campinas - Instituto de Economia. Tese (doutorado).

STOFFEL, J. Agricultura familiar nos Estados da Região Sul do Brasil: caracterização a partir dos dados do censo agropecuário de 2006. In: $6^{\mathbf{0}}$ Encontro de Economia Gaúcha, 2012, Porto Alegre. $6^{\circ}$ Encontro de Economia Gaúcha, 2012.

SUÁREZ, Sofía Monsalve. The human rights framework in contemporary agrarian struggles. The Journal of Peasant Studies, 40:1, 2013, pg. 239-290.

TEMPER, L.; DEL BENE, D. and MARTÍNEZ-ALIER, J. Mapping the frontiers and front lines of global environmental justice: the EJAtlas. Journal of Political Ecology, Volume 22, pg. 257-278, 2015. Disponível em: http://jpe.library.arizona.edu/volume_22/Temper.pdf. Acesso em: 10.03.2016. 
TRICHES, R. M. e GRISA C. Entre mudanças e conservadorismos: uma análise dos programas de aquisição de alimentos (PAA e PNAE) a partir da retórica da intransigência. REVISTA NERA, ANO 18, nº 26, EDIÇÃO ESPECIAL, 2015.

UNIVERSIDADE DE SÃO PAULO. Sistema Integrado de Bibliotecas da USP. Diretrizes para apresentação de dissertações e teses da USP : parte I (ABNT) / Sistema Integrado de Bibliotecas da USP ; Vânia Martins Bueno de Oliveira Funaro, coordenadora ; Vânia Martins Bueno de Oliveira Funaro... [et al.]. --3.ed. rev. ampl. mod. - - São Paulo : SIBiUSP, 2016. 100p. : il. -- (Cadernos de estudos ; 9).

VALADARES, A. A. e SOUZA, M. G. P. A trajetória recente do Programa de Aquisição de Alimentos da Agricultura Familiar (PAA): uma análise das mudanças normativas e institucionais que deram nova inflexão ao programa. Nota Técnica, $\mathbf{n}^{\mathbf{0}} \mathbf{2 1}$. Brasília: IPEA, 2015. 14p.

VAN DER ESCH, S.; BRINK, B.; STEHFEST, E.; BAKKENES, M.; SEWELL, A.; BOUWMAN, A.; MEIJER, J.; WESTHOEK, H.; VAN DEN BERG, M. Exploring future changes in land use and land condition and the impacts on food, water, climate change and biodiversity. PBL Netherlands Environmental Assessment Agency. PBL publication number: 2076. The Hague, 2017, 116p.

VASCONCELOS, J. M. M. Seguro da agricultura familiar (SEAF): História, implementação e desafios em Francisco Beltrão (PR). Programa de Pós Graduação em Agronegócios (Dissertação de Mestrado). Faculdade de Agronomia e Medicina Veterinária, UnB. Brasília, 2012, 136p.

VASCONCELOS, R. M. (editora técnica). Marcos regulatórios aplicáveis às atividades de pesquisa e desenvolvimento. Brasília, DF : Embrapa, 2016. 182 p.

VEIGA, R. F. A.; BARBOSA, W.; TOMBOLATO, A. F. C.; VALSS, J. F. M. Bancos de germoplasma: importância de organização. In: COSTA, A. M.; SPEHAR, C. A.; SERENO, J. R. B. Conservação de recursos genéticos no Brasil. Brasília: DF; Embrapa, 2012. pg. 104 125.

VIDA DIGNA NO CAMPO: desenvolvimento rural, política agrícola, agrária e de segurança alimentar. Programa de Governo 2002 - Coligação Lula Presidente. São Paulo; Partido dos Trabalhadores, Fundação Perseu Abramo, (2002). Disponível em: <www.lula.org.br/assets/vidadignanocampo.pdf $>$.

VIEIRA FILHO, J. E. R.; VIEIRA, A. C. P. A. Inovação na agricultura brasileira: uma reflexão a partir da análise dos certificados de proteção de cultivares. Texto para discussão 1866. Instituto de Pesquisa Econômica Aplicada.- Brasília : Rio de Janeiro : Ipea , 2013, 34p.

VILLAS BOAS, H. D. C. A empresa Pública de pesquisa e os marcos legais na indústria de sementes. Pelotas: Programa de Pós-Graduação em Ciência e Tecnologia de Sementes. Faculdade de Agronomia Eliseu Maciel. Universidade Federal de Pelotas.2008, 206 p. Tese (Doutorado).

WATTS, M.; PEET, R. Liberating Political Ecology. In PEET, R. and WATTS, M. (Ed.) Liberation Ecologies: Environment Development, and Social Movements. Routledge, 
London, 2004.

WILKINSON, J.; CASTELLI, P. G. A Transnacionalização da indústria de sementes no Brasil - biotecnologias, patentes e biodiversidade. Rio de Janeiro: ActionAid Brasil 2000.

WITTMAN, H. Food Sovereignty: A New Rights Framework for Food and Nature? Environment and Society: Advances in Research 2. Pg. 87-105, 2011. Disponível em: http://vssweb1.landfood.ubc.ca/publications/Wittman_2011_Food_Sovereignty_Review_Env _Society.pdf. Acesso em: 02.03.2016.

YAPA, L. Improved seeds and constructed scarcity. In: PEET, Richard.; WATTS, Michael. Liberation ecologies. Environment, development, social movements. Taylor \& Francis eLibrary, 2002, pg. 69-85.

ZUKOWSKI, J. C. Seguro agrícola e desenvolvimento rural - contribuições e desafios do seaf. In: GRISA, C.; SCHNEIDER, S. (org.). Políticas públicas de desenvolvimento rural no Brasil. Porto Alegre: Editora da UFRGS, 2015, pg 83 - 106. 


\section{ANEXO 1}

\section{Perguntas abertas com lideranças do MPA e OESTEBIO}

1) Como iniciou o Projeto de Sementes Crioulas?

2) Quais as instituições que foram envolvidas nesse processo?

i) No âmbito local/municipal:

ii) No âmbito regional/estadual:

iii) No âmbito nacional/internacional:

\section{1) Listar as instituições envolvidas:}

Linha do tempo

Início - desenvolvimento - saída

2) Campo de atuação - técnica - política - comercial - financeira

\section{3) Nível de envolvimento -}

i) Há um compromisso dos indivíduos ou da instituição?

ii) Há acordos formais?

iii) Desdobramentos dessas parcerias - Influenciou na formulação de políticas no âmbito das instituições?

iv) Listar quais:
a) Universidades
b) Instituições de Pesquisa
c) Ministérios (CONAB; MDA; MDS)
d) Empresas estaduais e secretarias de estados
e) Empresas, bancos e cooperativas de fomento
f) Outros

v) De que formas e durabilidade? Quanto tempo durou ou dura a parceria e como?

\section{Sobre o Desenho da Estratégia}

Caracterizar os sistemas de produção camponeses nos níveis da família e da comunidade.

Listagem das famílias - Quantas famílias compõe a rede de sementes crioulas nos seus diferentes níveis:

a) Famílias camponesas -

b) Comunidades que multiplicam -

c) Famílias e comunidades que abastecem a UBS - 
a) Caracterização das famílias camponesas que trabalham na rede do projeto de sementes crioulas.

\section{i) Estrutura das Propriedades}

a) Tamanho

b) Titulação/tipo de relação (arrendada; posseiro; outros)

c) Tem acesso a fontes de água - quais?

d) Tipos de solos e relevo predominante?

c) Apresentam problemas de manejo de solo (erosão, baixa fertilidade, desertificação)

d) Tipos de vegetação cultivada

\section{ii) Estrutura das famílias camponesas}

Tamanho das famílias (componentes) -

Adultos - Homens

Mulheres

Crianças

Jovens

Idosos

Quem é o chefe da família - homem ou mulher

Quem participa da rede do Projeto de Sementes, homens e mulheres? Qual a proporção?

Renda ( ) Menos de um salário mínimo ( ) 1 salário mínimo ( ) $2-5 \mathrm{sm} \mathrm{(} \mathrm{)} 5$ - $10 \mathrm{sm}$

Escolaridade ( ) Não frequentou a escola
( ) Assina o nome
( ) Ensino Fundamental incompleto
( ) EF completo
( ) Ensino Médio Incompleto
( ) EM Completo
( )Nível Superior Incompleto
( ) Nível Superior Completo
( ) Nível Superior
( ) Pós-graduação

Quanto tempo mora no lote?

\section{iii) Estrutura dos sistemas camponeses de produção}

Culturas predominantes

Tem animais? Quais? 
Tem maquinário? Quais? Individuais ou coletivos? Financiados ou adquirido por conta própria?

Tipos de práticas agrícolas - (usam adubação? Que tipo orgânica, química? usam irrigação? quais os tipos)

Tem registro de problemas com o clima? (secas, chuvas, inundações nos últimos anos?)

Fazem algum tipo de beneficiamento da produção na propriedade/comunidade?

\section{iv) Acesso a financiamentos e políticas públicas}

Tem acesso a políticas públicas? Quais?

Tem acesso a financiamentos? Quais?

Tem acesso a algum tipo de financiamento relacionados com o Projeto de Sementes Crioulas? Quais? Há quanto tempo? Há especificações por conta do projeto?

\section{v) Caracterização das comunidades}

a) Listar as comunidades envolvidas no projeto no município de São Miguel do Oeste/SC;

b) Localização das comunidades envolvidas no mapa do município com relação a sede da UBS; - DISTÂNCIAS

c) Fonte de recursos disponíveis nas comunidades com relação aos processos produtivos (água, estruturas de irrigação, etc)

d) Equipamentos de saúde, escola, campo de futebol, igrejas, etc

e) Culturas que predominam

f) Estrutura fundiária - minifúndios, médias propriedade, latifúndios

g) Agroindústrias

\section{vi) Comercialização}
a) Há comercialização da produção?
b) Quais os principais canais utilizados?
c) Qual percentual da produção é comercializado?
d) Há comercialização de sementes crioulas?
e) Principais canais 


\section{ANEXO 2 \\ ROTEIRO DE ENTREVISTA COM INSTITUIÇÕES}

\section{Questões}

1) Como o tema das sementes crioulas foi introduzido na instituição (histórico - linha do tempo)?

2) Que elementos (contexto político e institucional) determinaram essa possibilidade ?

3) O que é concebido como sementes crioulas na sua instituição?

4) Quais estratégias e ações estão sendo implementadas?

5) Quais atividades compõe o universo de ações em torno do tema sementes crioulas (volume de recursos e pessoal envolvido)?

6) Como tem sido a participação dos camponeses e suas organizações?

7) Quais as perspectivas para esse tema na sua instituição (curto, médio e longo prazo)? 